


\section{MET VERSTAND VAN ZAKEN. \\ PROFESSIONEEL HANDELEN EN CONCEPTUELE KENNIS IN DE LERARENOPLEIDING}

Christine Kemmeren 
PROMOTIECOMMISSIE

Voorzitter

Promotor

Co-promotor

Leden
Prof. Dr. T.A.J. Toonen • Universiteit Twente

Prof. Dr. J. M. Pieters • Universiteit Twente

Dr. E. van den Berg • Saxion Hogeschool

Prof. Dr. J. J. H. van den Akker - Universiteit Twente

Prof. Dr. W. A. J. M. Kuiper - Universiteit Utrecht

Dr. S. E. McKenney - Universiteit Twente

Prof. Dr. K. van Veen • Rijksuniversiteit Groningen

Prof. Dr. J. M. Voogt - Universiteit van Amsterdam

Kemmeren, C. M.

Met verstand van zaken. Professioneel handelen en conceptuele kennis in de lerarenopleiding

Proefschrift Universiteit Twente, Enschede.

ISBN 978-90-365-3843-5

DOI 10.3990/1.9789036538435

URL is: http://dx.doi.org/10.3990/1.9789036538435

Omslagontwerp: Niels de Groot

Layout: Sandra Schele

Printer: Ipskamp Drukkers B.V. Enschede

(C) Copyright, 2015, C. M. Kemmeren 


\title{
MET VERSTAND VAN ZAKEN. \\ PROFESSIONEEL HANDELEN EN CONCEPTUELE KENNIS IN DE LERARENOPLEIDING
}

\author{
DISSERTATIE \\ ter verkrijging van \\ de graad van doctor aan de Universiteit Twente, \\ op gezag van de rector magnificus, \\ prof. dr. H. Brinksma, \\ volgens besluit van het College voor Promoties \\ in het openbaar te verdedigen \\ op woensdag 22 april 2015 om 14.45 uur
}

door

Christine Maria Kemmeren

geboren op 9 mei 1968

te Amersfoort 
Promotor

Co-promotor
Prof. Dr. J. M. Pieters

Dr. E. van den Berg

Dit proefschrift is goedgekeurd door de promotor en de co-promotor. 


\section{NHOUDSOPGAVE}

Voorwoord $\mathbf{v}$

1. Inleiding 1

$\begin{array}{lll}1.1 & \text { Introductie van het theorie-praktijkvraagstuk } & 1\end{array}$

$\begin{array}{lll}1.2 & \text { Theoretisch kader en doelen van het onderzoek } & 6\end{array}$

1.3 Typering en opzet van het onderzoek $\quad 8$

$\begin{array}{ll}1.4 & \text { Vooruitblik op het onderzoek }\end{array}$

2. Theoretisch kader 11

Inleiding 11

$\begin{array}{ll}2.1 & \text { Cognitieve flexibiliteitstheorie } \\ & 11\end{array}$

$\begin{array}{lll}2.1 .1 & \text { Ill-structured domains } & 11\end{array}$

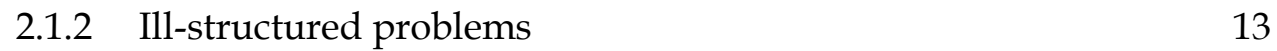

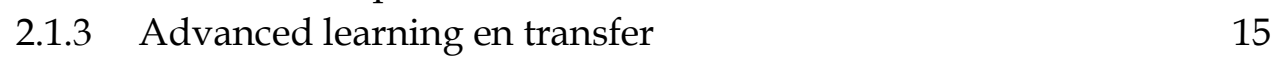

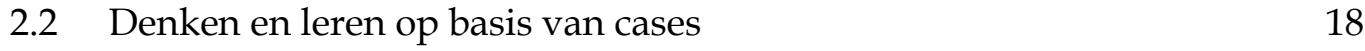

2.2.1 Case-based reasoning 18

$\begin{array}{ll}\text { 2.2.2 Case-based learning } & 22\end{array}$

2.2.3 Case-based learning en situated cognition $\quad 23$

2.3 Leren met video en rich media-cases $\quad 25$

2.3.1 Leren met video $\quad 25$

2.3.2 Soorten video- en rich media-cases 28

2.4 Instructie op basis van de cognitieve flexibiliteitstheorie 29

2.5 Betekenis voor het ontwerp 32

3 Ontwerp van curriculum en instructie 35

Inleiding 35

$\begin{array}{lll}3.1 & \text { Raamwerk } & 35\end{array}$

$\begin{array}{lll}3.2 & \text { Curriculumontwerp } & 37\end{array}$

3.2.1 Curriculumontwerp als geheel 37

3.2.2 Ontwerprichtlijn 1: gebruik maken van realistische
situaties

3.2.3 Ontwerprichtlijn 2: centrale concepten in diverse contexten bestuderen 40

3.2.4 Ontwerprichtlijn 3: cases interpreteren met behulp van concepten uit verscheidene domeinen 
3.3 Instructie-ontwerp

3.3.1 Ontwerprichtlijn 4: een beperkt aantal rijke videocases diepgaand bestuderen $\quad 48$

3.3.2 Vormgeving van onderwijs en leeromgeving 53

4 Tussen bedoeling en uitvoering: een evaluatie van het uitgevoerde curriculum

Inleiding

4.1 Overzicht en opzet van de formatieve evaluatie 57

$\begin{array}{lll}4.2 & \text { Samenvatting formatieve evaluaties } & 60\end{array}$

4.3 Formatieve evaluatie van het uitgevoerde curriculum 65

$\begin{array}{lll}\text { 4.3.1 Onderzoeksmethode } & 65\end{array}$

$\begin{array}{lll}\text { 4.3.2 Resultaten studenten } & 68\end{array}$

4.3.2.1 Leeropbrengst en motivatie voor casus 68

4.3.2.2 Opzet van het onderwijsarrangement 70

4.3.2.3 Werkwijze in het onderwijsarrangement 71

4.3.2.4 Presentatie en beoordeling 74

4.3.2.5 Materialen 76

4.3.2.6 Samenvatting resultaten studenten $\quad 77$

$\begin{array}{lll}4.3 .3 & \text { Resultaten docenten } & 79\end{array}$

$\begin{array}{lll}\text { 4.3.3.1 Leeropbrengst } & 79\end{array}$

$\begin{array}{lll}\text { 4.3.3.2 } & \text { Beoordelingsprocedure } & 80\end{array}$

$\begin{array}{lll}\text { 4.3.3.3 Materialen } & 81\end{array}$

4.3.3.4 Samenvatting resultaten docenten $\quad 83$

4.4 Conclusie formatieve evaluatie van uitgevoerd curriculum 84

5 Tussen bedoeling en resultaat: een evaluatie van het bereikte $\begin{array}{lr}\text { curriculum } & 87\end{array}$

$\begin{array}{lr}\text { Inleiding } & 87\end{array}$

5.1 Onderzoeksmethode $\quad 87$

$\begin{array}{lll}5.2 \text { Resultaten } & 90\end{array}$

5.2.1 Gevalsbeschrijving 1, Nick 90

5.2.2 Gevalsbeschrijving 2, Sas 93

5.2.3 Gevalsbeschrijving 3, Leanne 96

5.3 Resultaten van gevalsvergelijking 99

$\begin{array}{ll}5.4 \text { Conclusie } & 103\end{array}$ 
6 Cognitieve flexibiliteit in ontwikkeling 107

Inleiding 107

6.1 De interventie: onderwijsarrangement 2 107

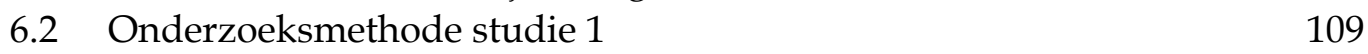

$\begin{array}{ll}6.3 & \text { Resultaten conceptgebruik } \\ 6.412\end{array}$

$\begin{array}{ll}6.4 \text { Conclusie } & 114\end{array}$

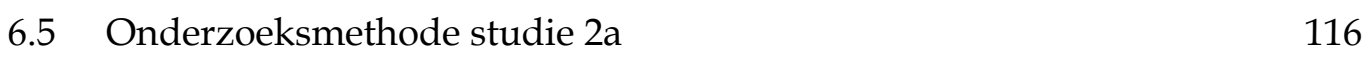

$\begin{array}{ll}\text { 6.6 Resultaten } & 122\end{array}$

6.6.1 Conceptgebruik in toelichting op handelen $\quad 122$

6.6.1.1 Resultaten 122

6.6.1.2 Duiding van sterke gevallen 124

6.6.1.3 Duiding van zwakke gevallen 126

6.6.1.4 Vergelijking van sterke en zwakke gevallen 127

$\begin{array}{ll}\text { 6.6.2 Conceptgebruik in reflectie } & 128\end{array}$

6.6.2.1 Resultaten 128

6.6.2.2 Duiding van alle gevallen 129

6.6.2.3 Conclusie 130

$\begin{array}{lll}\text { 6.6.3 Innemen van diverse perspectieven } & 130\end{array}$

6.6.3.1 Resultaten 130

6.6.3.2 Duiding van alle gevallen 134

6.6.3.3 Conclusie 135

6.7 Conclusie en discussie 136

6.8 Nadere data-analyse van kwaliteitsbevorderende elementen 138

6.8.1 Onderzoeksmethode studie 2b 138

$\begin{array}{lll}6.8 .2 & \text { Resultaten } & 138\end{array}$

$\begin{array}{ll}\text { 6.8.3 Vergelijking en conclusie } & 141\end{array}$

6.9 Slotconclusie en discussie 143

$\begin{array}{lll}7 & \text { Bereikte cognitieve flexibiliteit } & 147\end{array}$

$\begin{array}{ll}\text { Inleiding } & 147\end{array}$

$\begin{array}{lll}7.1 & \text { De interventie: onderwijsarrangement } 4 & 147\end{array}$

$\begin{array}{lll}7.2 & \text { Onderzoeksmethode studie } 1 & 149\end{array}$

$\begin{array}{lll}7.3 & \text { Resultaten } & 155\end{array}$

7.3.1 Duiding van drie goede gevallen 155

$\begin{array}{lll}\text { 7.3.2 Vergelijking van goede gevallen } & 168\end{array}$

$\begin{array}{lll}\text { 7.3.3 Duiding van zes voldoende gevallen } & 170\end{array}$

$\begin{array}{lll}\text { 7.3.4 Vergelijking van voldoende gevallen } & 187\end{array}$

$\begin{array}{lll}7.4 \text { Conclusie } & 189\end{array}$

7.5 Onderzoeksmethode studie 2

$\begin{array}{lll}7.6 & \text { Resultaten } & 195\end{array}$

$\begin{array}{lll}7.7 & \text { Conclusie en discussie } & 196\end{array}$ 
$\begin{array}{llr}8 & \text { Reflectie } & 199\end{array}$

8.1 Recapitulatie van het onderzoek 199

8.1.1 Achtergrond 199

8.1.2 Ontwerpen voor een concrete context 200

8.1.3 Doel en opzet van het onderzoek 201

8.1.4 Opbrengsten van het onderzoek 202

8.2 Reflectie op de toepassing van de cognitieve flexibiliteitstheorie 203

8.2.1 Probleemanalyse 204

8.2.2 Curriculum- en instructieontwerp 204

8.2.3 Inzicht in de manifestatie van cognitieve flexibiliteit 208

8.3 Reflectie op de formatieve evaluatie 209

8.3.1 Reflectie op opbrengsten 209

8.3.2 De kritische rol van de onderzoeker 211

$\begin{array}{lll}8.4 & \text { Discussie van de effectmeting } & 212\end{array}$

8.4.1 Opzet van de effectmeting 212

8.4.2 Bevindingen van effectmeting 1 en 2

8.5 Bijdrage aan de cognitieve flexibiliteitstheorie 218

8.6 Aanbevelingen 220

$\begin{array}{ll}\text { 8.6.1 Vervolgonderzoek } & 220\end{array}$

8.6.2 Aanbevelingen voor de lerarenopleiding 221

$\begin{array}{lr}\text { Referenties } & 225\end{array}$

$\begin{array}{ll}\text { English summary } & 233\end{array}$

$\begin{array}{lr}\text { Bijlagen } & 241\end{array}$

$\begin{array}{ll}\text { Curriculum Vitae } & 261\end{array}$ 


\section{VOORWOORD}

De weg is belangrijker dan het eindpunt. Zo keek ik er tegenaan voor ik aan dit promotieonderzoek begon. Ik wilde graag iets leren en ontdekken, en ook een mogelijke oplossing vinden. Gedurende de jaren dat ik als lerarenopleider aan het werk was, intrigeerde het mij namelijk steeds meer dat het zo ingewikkeld bleek om theorie en onderwijspraktijk betekenisvol op elkaar te betrekken. Hoe zouden we dat voor elkaar kunnen krijgen? Deze nieuwsgierigheid lag aan de basis van dit promotieonderzoek. Nu het eindpunt is bereikt, kijk ik terug op een traject waarin ik veel heb geleerd en waaraan heel veel mensen op hun eigen manier een bijdrage hebben geleverd. Ik wil graag iedereen bedanken voor die ondersteuning. Een aantal mensen noem ik daarbij in het bijzonder.

Natuurlijk gaat mijn dank allereerst uit naar de vele studenten die het onderwijs dat binnen het onderzoek werd ontworpen van feedback hebben voorzien - en die zich er vol enthousiasme en inzet in hebben gestort. Dat geldt ook voor alle basisscholen in de regio die bereid waren mee te gaan in een nieuwe ontwikkeling.

Mijn begeleiders in het onderzoek, Jules Pieters en Ellen van den Berg dank ik voor onze besprekingen. Jules, op de jou eigen, kalme wijze heb je steeds een verrassende en scherpe blik geworpen op het onderzoek. Mijn teksten kregen gedegen en gedetailleerd commentaar. Na een bespreking had ik weer stof tot nadenken en ook de juiste focus. Ellen, ik heb bewondering voor je kwaliteit om wetenschappelijke degelijkheid te combineren met gezond verstand en praktisch inzicht. Je hebt me daarmee op de juiste momenten richting gegeven in het onderzoek. Je begeleiding heeft langer geduurd dan we vooraf hadden kunnen denken. Het leven heeft mij de afgelopen jaren veel bijzondere ervaringen gebracht die tot onderbrekingen in het onderzoek hebben geleid. Of het nu prachtige of onplezierige aanleidingen betrof, je hebt me iedere keer op weg geholpen in het volste vertrouwen dat het allemaal goed zou komen.

Gabi Brühne (manager onderwijs) heeft mij gedurende het onderzoek altijd vertrouwen geschonken en in lastige tijden constructief meegezocht naar praktische oplossingen om het onderzoek mogelijk te maken. Inge Sterenborg (oud-directeur) heeft mij in de beginfase enthousiast gestimuleerd het project aan te gaan en stelde een deel van de onderzoekstijd beschikbaar. Dank jullie wel.

Collegae van en via het lectoraat Rich Media \& Teacher Learning hebben het onderzoek in verschillende fasen van feedback voorzien: Anne de Jong, Eric Koertshuis, Janine van de Linde, Ronald von Piekartz, Edmée Suasso en Maaike Vervoort. Erik Leeuw en Bouwe Koopal waren onmisbaar bij de ontwikkeling van de digitale concept map. We hebben intensief samengewerkt, waarbij jullie in staat waren een vertaling te 
maken van conceptueel denken naar ict-toepassing. Dank hiervoor - en voor de altijd vrolijke samenwerking! Anne Broekhuis, student-assistent, heeft diverse werkzaamheden verricht voor het onderzoek. Dank voor je consciëntieuze aanpak. Edmée, bedankt voor je suggesties en het luisterend oor dat je me steeds hebt geboden.

Zonder onderwijsgevenden geen onderwijsonderzoek. Dank gaat dan ook uit naar alle betrokken collegae en vooral naar de vakgroep Nederlands: Anique Bokdam, Leonie Beijen, Yvonne van Elten, Trees van de Hoogt, Johan Oude Engberink en Richard Vollenbroek. Jullie hebben meegewerkt aan het ontwerp van het onderwijs en/of waren altijd bereid om experimenteel onderwijs uit te voeren - in die innovatieve cultuur hebben ook diverse oud-collegae dat vanzelfsprekend gedaan. Bedankt voor jullie collegialiteit, flexibiliteit en deskundigheid. Ik dank Johan in het bijzonder voor zijn bijdrage aan het onderzoek en zijn grote inzet bij het onderwijs. Verder hebben veel andere collegae in de loop der tijd hun belangstelling getoond voor het onderzoek en mij daarmee gemotiveerd.

Collegae van de voormalige afdeling Curriculumontwerp \& Onderwijsinnovatie van de Universiteit Twente dank ik voor de jarenlange samenwerking. Er heerste een plezierige werksfeer - en de fameuze koffie $^{+}$op dinsdagmorgen was een mooi moment voor informele uitwisseling van onderzoekskwesties. Van velen heb ik een zetje in de goede richting gekregen.

Leraren van het team van de openbare daltonschool Europa in Enschede hebben bijgedragen aan de ontwikkeling van videocases. Het was plezierig samenwerken met jullie allemaal en ik voelde me altijd welkom.

Maaike en Anne, jullie waren en zijn al jarenlang mijn trouwe kamergenoten. Of we nu een knusse zolderkamer delen, een zakelijke flexruimte of een riant kantoor, we weten werk en humor altijd te combineren. Het is fijn dat onze paden nog steeds parallel lopen.

Sandra Schele bedank ik voor haar deskundige ondersteuning bij de lay-out en publicatie van dit proefschrift en haar rol als vraagbaak. Nora Schadee bedank ik voor het deskundig commentaar op de Engelstalige samenvatting van dit proefschrift. En mijn broers Paul en Rob voor hun heldere en constructieve blik op teksten en lay-out.

Er kan niet altijd gewerkt worden, hoewel de laatste fase van zo'n promotieonderzoek soms wel die indruk wekt. Mijn vrienden heb ik de laatste tijd enigszins verwaarloosd en ik hoop dat binnenkort goed te maken. Dank voor jullie begrip, belangstelling, telefoongesprekken, wandelingen, etentjes et cetera in de afgelopen jaren! Ik wil mijn beide ouders, Jochem en Stien, uit de grond van mijn hart bedanken voor hun trouwe, niet-aflatende praktische hulp en hun vertrouwen in mij. Wat moeten wij nu voortaan op vrijdag doen? En ten slotte, het is onvoorstelbaar mooi om een thuisbasis te hebben die relativerend en ontspannend werkt. Niels en Annemoon, mijn onuitsprekelijke dank is voor jullie.

Christine Kemmeren 


\section{HOOFDSTUK 1}

\section{Inleiding}

In dit proefschrift wordt geëxploreerd hoe theorie en praktijk in de lerarenopleiding betekenisvol met elkaar kunnen worden verbonden. Onderzocht wordt hoe een leerproces kan worden bevorderd waarin conceptuele kennis een betekenisvolle en sturende rol krijgt voor het professioneel handelen van studenten. Daartoe wordt in een ontwerponderzoek een curriculum- en instructieontwerp ontwikkeld en geëvalueerd. Het onderzoek vindt plaats in de lerarenopleiding voor primair onderwijs. Hoofdstuk 1 vormt de inleiding op het onderzoek. Eerst worden het onderwerp, de achtergrond van het theorie-praktijkvraagstuk en de centrale vraagstelling geïntroduceerd in paragraaf 1.1. Daarna wordt de wetenschappelijke positionering van het onderzoek weergegeven; hierbij is de cognitieve flexibiliteitstheorie als invalshoek genomen. Tevens worden de doelstellingen van het onderzoek beschreven in paragraaf 1.2. Vervolgens wordt in paragraaf 1.3 toegelicht welke onderzoeksbenadering is gehanteerd en wordt de opbouw van het proefschrift beschreven in paragraaf 1.4 .

\subsection{Introductie van het theorie-praktijkvraagstuk}

Lerarenopleidingen staan voor de taak studenten op te leiden tot professionals die met verstand van zaken handelen in de beroepspraktijk. Die beroepspraktijk is gevarieerd: Leraren en leraren-in-opleiding worden in hun beroepsuitoefening voortdurend geconfronteerd met complexe en nieuwe situaties waarin zij beslissingen nemen en handelen. Van hen wordt verwacht dat zij deze beslissingen kunnen onderbouwen op grond van de kennisbasis van het leraarsberoep (Borko, 2004; Putnam \& Borko, 2000). Een belangrijke doelstelling binnen de lerarenopleiding is dan ook dat studenten in staat zijn om hun professioneel handelen met behulp van een theoretisch referentiekader te beredeneren. Studenten, lerarenopleiders en leraren in het beroepsveld ervaren echter een discrepantie tussen de theoretische inzichten die in de opleiding aangereikt worden en de realistische situaties die zich voordoen in de praktijk van alledag: het aanwenden van theorie om het professioneel handelen mee te beredeneren blijkt problematisch. De toepassing van theorie op praktijksituaties blijkt complex en de relevantie van theorie voor professioneel handelen wordt door studenten niet altijd ervaren. Dit onderzoek gaat over de problematische relatie tussen theorie en praktijk in de lerarenopleiding voor primair onderwijs, kortweg aangeduid met 'het theorie-praktijkvraagstuk'. Beoogd wordt een weg te vinden waarmee theorie voor studenten een betekenisvol en behulpzaam 
middel wordt voor het begrijpen van en professioneel handelen in praktijksituaties. In deze paragraaf wordt het theorie-praktijkvraagstuk nader geïntroduceerd.

\section{Het theorie-praktijkvraagstuk vanuit maatschappelijk perspectief}

De lerarenopleiding bevindt zich in het brandpunt van een politiek en maatschappelijk debat. Het niveau van de lerarenopleidingen staat, ook internationaal, ter discussie en met name de vraag naar de plaats van theorie in het curriculum dringt zich op. In het publieke debat wordt een wirwar aan begrippen gebruikt (theorie, kennis, pedagogiek, didactiek, onderwijskunde, psychologie, basisschoolvakken, algemene ontwikkeling et cetera) en is onduidelijk wat precies wordt verstaan onder theorie, maar onbetwistbaar is het maatschappelijk belang dat wordt toegedicht aan afgestudeerde leraren van voldoende niveau. Nederlandse lerarenopleidingen in het bijzonder worden geconfronteerd met politieke druk om het theoretisch gehalte van hun curricula te verantwoorden, wat uiteindelijk voor pabo's heeft geresulteerd in de ontwikkeling en geleidelijke invoering van een serie landelijke kennisbasistoetsen (in de periode 2008-2014) ${ }^{1}$. In een dergelijk klimaat waarin de verantwoordingsdruk toeneemt, dienen lerarenopleidingen in staat te zijn een overtuigend antwoord te geven op de vraag naar de rol van theorie in een beroepsopleiding en het theoretisch gehalte van het curriculum. Daarmee krijgt het complexe vraagstuk van de relatie tussen theorie en praktijk een hernieuwde urgentie.

\section{Het theorie-praktijkvraagstuk vanuit opleidingsperspectief}

Lerarenopleidingen zijn altijd op zoek naar een balans tussen theorie en praktijk in het curriculum. De curricula van lerarenopleidingen zijn verschillend vormgegeven, maar zij combineren altijd een theoretische component (formele of conceptuele kennis in de vorm van een instituutscurriculum) en een praktische component (in de vorm van stages) in de verwachting dat de transfer van theorie naar praktijk plaatsvindt. In die verwachting worden opleidingen teleurgesteld. De ervaring leert immers dat het aanwenden van theorie door studenten om het professioneel handelen mee te sturen, moeizaam plaatsvindt. Het leren hanteren van theorie om praktijksituaties te begrijpen en professioneel te handelen, blijkt een hardnekkig en complex vraagstuk dat geen eenvoudige oplossingen kent. Een terugkerende vraag in de ontwikkeling van het curriculum is dan ook hoe de aansluiting van theorie en praktijk tot stand gebracht of verbeterd kan worden.

In de afgelopen decennia is vanuit verschillende invalshoeken gepoogd om de verbinding van theorie en praktijk in het curriculum van de lerarenopleiding te bewerkstelligen. Het denken over curriculumontwikkeling in de lerarenopleiding wordt gekenmerkt door een diep besef van het belang van de rol van de praktijk en het professioneel handelen. Een voorbeeld hiervan is de ontwikkeling van het opleidingsmodel Opleiden-in-de-school (OidS), gebaseerd op de professional

1 In dit proces hebben twee commissies een rol gespeeld: de Expertgroep Doorlopende Leerlijnen (ofwel commissie Meijerink) in 2008 en de Commissie Kennisbasis Pabo in 2012. 
development schools, waarin nauw wordt samengewerkt tussen professionals in de praktijk en lerarenopleiders (Darling-Hammond, 2006b; Geldens, 2007); hiermee wordt beoogd inzichten uit de theorie en de praktijk bij elkaar te brengen en bij te dragen aan de ontwikkeling van de student, de school en het opleidingsinstituut. Vanuit een heel andere invalshoek heeft de wet op de beroepen in het onderwijs (wet Bio, 2006) waarin de competenties van het leraarsberoep staan beschreven, bijgedragen aan curriculumvernieuwingsprocessen waarin gepoogd wordt theorie en praktijk aan elkaar te verbinden.

Niet alleen de rol van de praktijk, maar ook de rol van theorie in het curriculum van de lerarenopleiding verdient bezinning bij de inrichting van het curriculum waarin theorie en praktijk in samenhang met elkaar worden gebracht. Het is immers primair de verantwoordelijkheid van de lerarenopleiding om studenten toe te rusten met (nieuwe) relevante theoretische inzichten voor de beroepspraktijk. Het ontwikkelen van een theoretisch referentiekader bij studenten is binnen een beroepsopleiding geen doel op zichzelf, maar staat ten dienste van het professioneel handelen. Dat studenten beroepsvaardigheden ontwikkelen in combinatie met een theoretisch referentiekader is van groot belang voor het entameren van een effectief leerproces. Het gebruik van theorie kan namelijk bijdragen aan een abstractere wijze van kijken naar de werkelijkheid, waardoor overeenkomsten en verschillen tussen uiteenlopende praktijksituaties sneller en preciezer worden waargenomen en geïnterpreteerd. Een wezenlijke vraag voor de lerarenopleiding is daarom hoe theorie betekenisvol en productief kan worden voor het professioneel denken en handelen van studenten.

Een concrete situatie waarin het theorie-praktijkvraagstuk zich manifesteert, doet zich voor op een lerarenopleiding voor primair onderwijs. Ten tijde van het onderzoek bevindt deze lerarenopleiding zich in een curriculumvernieuwingsproces waarin de overgang wordt gemaakt van een modulair ingericht curriculum naar een curriculum dat inhoudelijk is gestoeld op de competenties van het lerarenberoep. Gezocht wordt naar een manier waarop een leerproces kan worden bevorderd waarin de ontwikkeling van professionele vaardigheden en een theoretisch referentiekader samenhangend plaatsvindt. In dit vernieuwingsproces heeft de lerarenopleiding behoefte aan de ontwikkeling van competentiegericht onderwijs. Binnen dit onderzoek is gekozen voor de ontwikkeling van onderwijs over het onderwerp 'Communicatie met ouders'. De keuze voor dit onderwerp komt voort uit aanbevelingen van de adviesraad en alumni die beiden adviseren meer aandacht aan dit onderwerp te besteden vanuit het toegenomen belang dat wordt gehecht aan een goede samenwerkingsrelatie tussen ouders en school. Dit onderwerp kreeg tot nu toe beperkte aandacht in het curriculum. Deze concrete situatie vraagt om een praktische en contextgebonden oplossing. De noodzaak van een goede voorbereiding op communicatie met ouders is overigens niet lokaal: beginnende leraren ervaren het contact met ouders in het algemeen en specifiek in een grootstedelijke context (hoogopgeleide ouders, interculturele achtergronden) als problematisch (Gaikhorst, 2014). 


\section{Het theorie-praktijkvraagstuk vanuit wetenschappelijk perspectief}

De complexe relatie tussen theorie en praktijk in de lerarenopleiding is al decennia onderwerp van onderzoek. Onderzoek heeft zich gericht op de aard van de professionele kennisbasis van het lerarenberoep en de leerprocessen van leraren met gevolgen voor de inrichting van het curriculum van lerarenopleidingen.

Een belangrijk aspect van het theorie-praktijkvraagstuk is gelegen in de aard van de professionele kennisbasis van leraren. Onderzoek naar teacher learning heeft inzicht gegeven in de complexiteit van de professionele kennisbasis. Deze kennisbasis is veelzijdig en beslaat kennis uit verschillende domeinen, namelijk kennis van 'Learners and their development', 'Teaching' en 'Subject matter and curriculum goals' (Darling-Hammond, 2006a, p. 304). Een complicerende factor is dat de professionele kennisbasis bestaat uit verschillende soorten kennis zoals formele, expliciet geformuleerde kennis en veelal impliciete praktijkkennis, en bovendien beïnvloed wordt door veranderende opvattingen over onderwijs (Labaree, 2003). De aard van de professionele kennisbasis voor leraren, met zijn grote hoeveelheid betrokken disciplines en verschillende soorten kennis, draagt bij aan de complexiteit van het verbinden van theorie en praktijk.

Ideeën van ken- en leertheoretische aard hebben de discussie over de aard van de professionele kennisbasis van leraren, de relatie tussen theorie en praktijk en de daarmee samenhangende inrichting van de curricula van lerarenopleidingen beïnvloed. Vanuit een situated cognition-perspectief op kennis en leren wordt gesteld dat zowel het leerproces als de kennis situated zijn, dat wil zeggen onverbrekelijk verbonden met en gevormd door de omstandigheden en de cultuur waarin zij tot stand komen (Brown, Collins \& Duguid, 1989). Een gevolg van deze opvatting is dat authentieke activiteiten en contexten een centrale rol krijgen in het leren en dat onderzoek zich nadrukkelijker heeft gericht op de rol van de praktijk in het opleiden van leraren en de aard van praktijkkennis van leraren (Meijer, 1999).

In dit kader kan ook het onderzoek naar case-based learning worden geplaatst. Het leren op basis van cases (in de vorm van video- of multimediacases) heeft zijn basis in de gedachte dat kennis gecontextualiseerd is en dat een leerproces waarin de theorie ten dienste staat van het professioneel handelen het beste vormgegeven kan worden aan de hand van representaties van die praktijk (Merseth, 1996; Shulman, J. 1992; Shulman, L., 1992, 1996). Dit gedachtegoed heeft een onderzoekstraditie op gang gebracht waarin de inzet van cases, in de vorm van video- of multimediacases, voor de verbinding van theorie en praktijk centraal staat. Recent onderzoek heeft onder andere inzicht gegeven in het belang van praktijkkennis van ervaren leraren voor het leerproces van studenten. Zo is het voor de toepassing van theoretische inzichten in de praktijk door studenten behulpzaam dat ervaren professionals als mediator optreden en hun praktijkkennis expliciteren en toegankelijk maken voor studenten (Vervoort, 2013).

Samenhangend met het gedachtegoed over de aard van de professionele kennisbasis en de wenselijke leerprocessen zijn ideeën geformuleerd over de inrichting van het curriculum van de lerarenopleiding (Cochran-Smith, 2005; Cochran-Smith \& Lytle, 
1999; Darling-Hammond, 2006a, 2006b; Grossman, Hammerness, \& McDonald, 2009). Zo is voorgesteld om het traditionele onderscheid in het 'leren voor de praktijk' (theorie in lerarenopleiding) en het 'leren in de praktijk' (stage in school) te overwinnen door het 'leren van de praktijk' te introduceren, waarmee een vruchtbare wisselwerking tussen theorie en praktijk wordt beoogd (Cochran-Smith \& Lytle, 1999). Het theorie-praktijkvraagstuk is ook benaderd vanuit de vraag waarom wetenschappelijke inzichten zo moeizaam ingang vinden in de onderwijspraktijk. Het traditionele research-development-diffusion-model (RDD-model) waarin kennis wordt ontwikkeld in een universitaire context, vertaald wordt in producten en toegepast wordt in het onderwijs, blijkt niet optimaal te werken. De oorzaken hiervoor worden gezocht in de scheiding tussen degenen die de kennis ontwikkelen (onderzoekers) en degenen die kennis toepassen (leraren), het type kennis dat wordt ontwikkeld in onderzoek dat niet betekenisvol voor de praktijk blijkt en de beperkte aandacht voor de context waarin de kennis zou moeten worden toegepast (van den Berg \& Kwakman, 2004). Als reactie op dit model is een stroming op gang gekomen die bepleit dat leraren zelf, individueel of in teamverband, kennis ontwikkelen door het uitvoeren van praktijkonderzoek (Bartlett \& Burton, 2012; Burton \& Bartlett, 2006; Lunenberg, Ponte, \& van de Ven, 2006; Pareja Roblin et al., 2014; Ponte, 2002; Schön, 1987; Wenger, McDermott, \& Snyder, 2002; Zwart, Lunenberg, \& Volman, 2010). Dit komt de relevantie en de toepasbaarheid van de ontwikkelde kennis ten goede en leidt tot meer eigenaarschap ervan bij leraren, waardoor het een goede oplossingsrichting is voor het theorie-praktijkvraagstuk. Het zelf ontwikkelen van kennis door middel van praktijkonderzoek is echter een arbeidsintensief proces en is, de omvang van de professionele kennisbasis in aanmerking genomen, geen haalbare werkwijze voor de inrichting van het gehele curriculum van een lerarenopleiding.

Samengevat zijn er drie verschillende motieven voor het onderzoek: Ten eerste is vanuit wetenschappelijk oogpunt het leerproces waarin theorie en praktijk worden verbonden nog onvoldoende doorgrond. Ten tweede is vanuit de praktijk van de lerarenopleiding het ontwikkelen van een curriculum waarin theorie en praktijk betekenisvol worden verbonden een nog onopgelost vraagstuk waarvoor praktische oplossingen worden gezocht. En ten derde bestaat vanuit maatschappelijk oogpunt de behoefte aan een lerarenopleiding die de plaats van theorie en praktijk in haar curriculum helder kan verantwoorden.

Daarom wordt in dit proefschrift gefocust op de ontwikkeling van conceptuele kennis van leraren-in-opleiding en de relatie tussen conceptuele kennis ${ }^{2}$ en professioneel handelen. De vraag die ten grondslag ligt aan het onderzoek luidt:

Hoe kan een betekenisvolle verbinding worden bewerkstelligd tussen conceptuele kennis en professioneel handelen in de lerarenopleiding?

2 De term 'conceptuele kennis' wordt in dit proefschrift gehanteerd als overkoepelend begrip voor de theorie die in (een domein van) het curriculum van de lerarenopleiding wordt aangeboden. Zie hoofdstuk 3. 


\subsection{Theoretisch kader en doelen van het onderzoek}

In deze paragraaf worden de contouren geschetst van het theoretisch kader waarbinnen is gezocht naar een oplossing voor het probleem en worden de doelen van het onderzoek geformuleerd. Een nadere uitwerking van het theoretisch kader is te vinden in hoofdstuk 2.

\section{Theoretisch kader}

Als theoretisch kader voor de betekenisvolle verbinding van conceptuele kennis en professioneel handelen bij het onderwerp communicatie met ouders, wordt de Cognitive Flexibility Theory gehanteerd (Jacobson \& Spiro, 1995; Jones \& Spiro, 1992; Spiro, Collins, \& Ramchandran, 2007; Spiro, Collins, Thota, \& Feltovich, 2003; Spiro \& DeSchryver, 2009; Spiro, Feltovich, Jacobson, \& Coulson, 1992). De cognitieve flexibiliteitstheorie (CFT) richt zich namelijk specifiek op de toepassing van conceptuele kennis op complexe praktijksituaties in zogenaamde ill-structured domeinen. In dergelijke domeinen is het onmogelijk om via de toepassing van vaste procedures en welomschreven concepten tot een adequate oplossing van een probleem te komen. De lerarenopleiding - en daarbinnen het domein communicatie met ouders - laat zich karakteriseren als zo'n ill-structured domein. Een algemene doelstelling van deze leer- en instructietheorie is het verwerven van transferabele kennis, waarmee complexe praktijksituaties kunnen worden begrepen (geanalyseerd/geïnterpreteerd) door concepten uit verschillende domeinen met oog voor de specifieke context flexibel te combineren en toe te passen. Dit wordt ook wel kortweg aangeduid met cognitieve flexibiliteit. De theorie geeft inzicht in het samenspel van factoren dat maakt dat de toepassing van conceptuele kennis problematisch is.

In de CFT kunnen drie dimensies worden onderscheiden die betrekking hebben op het vraagstuk van de verbinding van conceptuele kennis aan praktijksituaties. Deze veelzijdige benadering van de CFT op het vraagstuk van de verbinding theoriepraktijk biedt aanknopingspunten voor een oplossing.

Ten eerste wordt het begrip 'conceptuele kennis' of 'theorie' geproblematiseerd vanuit een kentheoretisch perspectief. Verduidelijkt wordt dat de conceptuele kennis in ill-structured domeinen op zichzelf complex en soms diffuus is, waardoor een eenvoudige toepassing van concepten bemoeilijkt wordt. Bovendien wordt uitgegaan van een situated knowledge view, waarbij de betekenis van concepten ingebed is in de praktijksituaties en zich manifesteert in die praktijksituaties. Ten tweede wordt vanuit een leertheoretisch perspectief een leerproces op basis van cases (case-based learning) voorgesteld als een veelbelovende voorbereiding op het handelen in complexe praktijksituaties. Met behulp van case-based reasoning, een theorie over cognitie en cognitieve processen, wordt een theoretische onderbouwing gegeven voor de wijze waarop mensen leren op basis van cases. Ten derde worden binnen de CFT vanuit een instructietechnologisch perspectief richtlijnen gegeven voor het inrichten van een (digitale) leeromgeving met videocases als centraal element. 
In dit proefschrift wordt de CFT gehanteerd in de context van een beroepsopleiding. De empirische basis van de CFT ligt voornamelijk in de (Amerikaanse) academische context (Choi \& Lee, 2009; Derry, Hmelo-Silver, Nagarajan, Chernobilsky, \& Beitzel, 2006; Derry \& STEP Team, 2003; Eilam \& Poyas, 2006). Met 'toepassing van conceptuele kennis' en 'handelen' wordt in de academische context geduid op cognitieve vaardigheden zoals het analyseren en interpreteren van praktijksituaties. In een beroepsopleiding echter heeft handelen een andere betekenis en dient het toepassen van conceptuele kennis niet alleen een intellectueel doel, maar heeft het ook gevolgen voor het professioneel handelen in de beroepspraktijk. In dit onderzoek worden de uitgangspunten van de CFT geoperationaliseerd voor een interventie die functioneert in een beroepsopleidingscontext en wordt de waarde van de CFT voor zo'n context beproefd.

\section{Doelen}

Dit onderzoek heeft twee doelstellingen. In dit onderzoek wordt ten eerste beoogd een interventie te ontwerpen en te evalueren die een leerproces van aanstaande leraren bewerkstelligt waarin conceptuele kennis en professioneel handelen betekenisvol met elkaar worden verbonden. De 'verbinding van conceptuele kennis en professioneel handelen' wordt beschouwd met behulp van de cognitieve flexibiliteitstheorie en geconcretiseerd in termen van cognitieve flexibiliteit. Het doel van de interventie is om een leerproces te bevorderen dat bijdraagt aan de ontwikkeling van cognitieve flexibiliteit. Met behulp van het onderzoek wordt ernaar gestreefd inzicht te verkrijgen in dit leerproces en de wijze waarop de cognitieve flexibiliteit van aanstaande leraren (studenten) zich manifesteert.

De interventie is bedoeld om een concreet probleem op te lossen en dient te functioneren in een realistische onderwijssetting. Dit betekent dat zij zich moet bewegen binnen bepaalde randvoorwaarden om daadwerkelijk bruikbaar te zijn. Daarmee is binnen dit onderzoek niet alleen de effectiviteit van een theoretisch onderbouwde interventie aan de orde, maar ook de vraag naar de haalbaarheid daarvan in een realistische context. Aanbevelingen vanuit wetenschappelijk onderzoek geven richting aan het denken, maar zijn vaak onvoldoende concreet of kunnen in de beperkte mogelijkheden van de alledaagse werkelijkheid niet worden gerealiseerd. De uitdaging bij het ontwerpen van een interventie is om binnen de randvoorwaarden die de concrete situatie met zich meebrengt, een realistische oplossing te vinden.

De tweede doelstelling van het onderzoek is een bijdrage te leveren aan de cognitieve flexibiliteitstheorie door te onderzoeken op welke wijze deze theorie kan worden toegepast in de context van een beroepsopleiding. Nagegaan wordt welke waarde de theorie heeft voor 'het betekenisvol verbinden van theorie en praktijk' in de lerarenopleiding. 


\subsection{Typering en opzet van het onderzoek}

In dit onderzoek is een ontwerpgerichte onderzoeksbenadering gehanteerd, omdat deze benadering aansluit bij de doelen van het onderzoek in dit proefschrift. Een toelichting op de methodologie wordt in deze paragraaf gegeven, gevolgd door een beschrijving van de onderzoeksopzet.

\section{Ontwerponderzoek}

De doelstellingen van ontwerponderzoek zijn tweeledig. Ten eerste neemt ontwerponderzoek complexe problemen in de onderwijspraktijk als uitgangspunt voor onderzoek en stelt zich ten doel oplossingen voor deze complexe problemen te ontwerpen op basis van zowel wetenschappelijke inzichten als op een analyse van de context waarin de oplossing moet functioneren. Dit uitgangspunt betekent dat de praktische relevantie van ontwerponderzoek groot is aangezien zij oplossingen (ook interventies genoemd) voortbrengt die toepasbaar zijn in een realistische context.

Ten tweede stelt ontwerponderzoek zich ten doel kennis te ontwikkelen over het ontwerpproces, over de kenmerken van de ontworpen oplossing en over het implementatieproces. Typerend voor de bijdrage aan theorievorming door ontwerponderzoek is dat die tot stand komt door het empirisch beproeven van interventies in realistische onderwijscontexten (van den Akker, Gravemeijer, McKenney, \& Nieveen, 2006; McKenney \& Reeves, 2012; Plomp \& Nieveen, 2009).

\section{Onderzoeksopzet}

In dit onderzoek wordt een interventie ontworpen voor een realistisch en complex onderwijsprobleem. De interventie is gericht op het bewerkstelligen van een betekenisvolle verbinding van conceptuele kennis en professioneel handelen, kortweg genoemd 'beredeneerd professioneel handelen'. Het onderzoek bestaat uit drie fasen.

In de eerste fase van het onderzoek vindt de probleemanalyse plaats en wordt de interventie ontwikkeld. Op basis van inzichten uit de cognitieve flexibiliteitstheorie en case-based learning worden ontwerpprincipes geformuleerd en, met inachtneming van de specifieke context, geoperationaliseerd in een gedetailleerd uitgewerkt vierjarig curriculum- en instructieontwerp voor het domein communiceren met ouders.

In de tweede fase van het onderzoek vinden de implementatie en formatieve evaluatie van de interventie plaats. Dit houdt in dat de vier onderwijsarrangementen waaruit de interventie bestaat, worden geëvalueerd op praktische bruikbaarheid en effectiviteit met als bedoeling de interventie te verbeteren en tegelijkertijd inzicht te verkrijgen in de werking en potentiële effectiviteit van de onderwijsarrangementen ${ }^{3}$.

3 In een project voorafgaande aan dit onderzoek is de levensvatbaarheid van het instructieontwerp aangetoond en zijn diverse kwaliteitsaspecten van de curriculummaterialen (met name validiteit, verwachte effectiviteit, competentiegerichtheid en bruikbaarheid) geëvalueerd in twee studies (Thijs, 2005; Kemmeren, 2005). Zie hoofdstuk 4 voor een nadere toelichting. 
De formatieve evaluaties van de onderwijsarrangementen vinden plaats in de reële onderwijssetting met behulp van try-outs. In deze fase worden verschillende typen data verzameld (onder andere interviewgegevens, producten van studenten, observatiegegevens) onder verschillende gebruikersgroepen (studenten en docenten) en op kwalitatieve wijze geanalyseerd.

In de derde fase van het onderzoek vindt de effectevaluatie van de interventie plaats in twee delen. De eerste effectevaluatie betreft het tweede onderwijsarrangement van de interventie (bij tweedejaars studenten) en de tweede effectevaluatie betreft het laatste onderwijsarrangement (bij vierdejaars studenten). Met behulp van de studies wordt inzicht verkregen in het leerproces en de kwaliteit van de leerresultaten van studenten in het beginstadium en in het eindstadium van de interventie. In deze fase worden producten van studenten geanalyseerd op overwegend kwalitatieve wijze.

\subsection{Vooruitblik op het onderzoek}

Dit proefschrift is opgebouwd in twee delen. Het eerste deel van het proefschrift bevat het theoretisch kader en een beschrijving van de ontwikkeling van de interventie. In hoofdstuk 2 wordt verslag gedaan van het literatuuronderzoek en in hoofdstuk 3 wordt beschreven hoe dit theoretisch fundament is vertaald in een vierjarig curriculum- en instructieontwerp.

De formatieve evaluatie van het curriculum- en instructieontwerp wordt gepresenteerd in twee aparte hoofdstukken. Hoofdstuk 4 geeft een overzicht van de uitgevoerde studies en bevat een studie naar de praktische bruikbaarheid. Hoofdstuk 5 bevat een studie naar de potentiële effectiviteit van de interventie.

Het tweede deel van het proefschrift bevat de effectevaluatie van de interventie, die ook wordt gepresenteerd in twee aparte hoofdstukken. Hoofdstuk 6 richt zich op de evaluatie van deel 2 van het curriculum- en instructieontwerp, hoofdstuk 7 richt zich op de evaluatie van deel 4 van het curriculum- en instructieontwerp. Met behulp van de studies wordt inzicht verkregen in het leerproces en de kwaliteit van de leerresultaten van studenten in het begin- en eindstadium van de interventie.

Het proefschrift wordt afgesloten met een reflectie op het onderzoek in hoofdstuk 8 . In dit laatste hoofdstuk wordt gereflecteerd op de waarde van de cognitieve flexibiliteitstheorie voor het onderzoeks- en ontwerpproces en worden de bevindingen uit het onderzoek bediscussieerd. Suggesties voor vervolgonderzoek worden geformuleerd. Ook worden aanbevelingen gedaan voor de praktijk van de lerarenopleiding op het gebied van curriculumontwikkeling en de rol van conceptuele kennis daarin. 


\section{HOOFDSTUK 2}

\section{Theoretisch kader}

\section{Inleiding}

In dit hoofdstuk wordt het theoretisch kader waarop het onderzoek is gebaseerd, beschreven. In paragraaf 2.1 wordt ingegaan op het ken- en leertheoretische gedachtengoed van de cognitieve flexibiliteitstheorie en worden centrale begrippen uit deze theorie toegelicht. Omdat de cognitieve flexibiliteitstheorie uitgaat van een leerproces op basis van videocases wordt in paragraaf 2.2 ingegaan op het denken en leren op basis van cases. Vanuit de invalshoek van case-based reasoning wordt ook een theoretisch onderbouwing gegeven voor case-based learning. Het specifieke medium video en de rol van videocases in het leerproces van leraren staan in paragraaf 2.3 centraal. Besproken wordt wat geleerd kan worden met behulp van video en welke verschillende soorten video in het leerproces kunnen worden ingezet. In paragraaf 2.4 wordt verhelderd hoe de voorgaande elementen de basis vormen voor de instructietheorie van de cognitieve flexibiliteitstheorie. Afgesloten wordt in paragraaf 2.5 met de formulering van richtlijnen voor het ontwerp van een instructie die is gebaseerd op de ideeën van de cognitieve flexibiliteitstheorie.

\subsection{Cognitieve flexibiliteitstheorie}

In deze paragraaf wordt eerst een introductie gegeven op de cognitieve flexibiliteitstheorie door het begrip ill-structured domain toe te lichten (2.1.1); vervolgens wordt nader ingegaan op onderzoek naar ill-structured problems (2.1.2) en tenslotte wordt ingegaan op de doelstelling van de cognitieve flexibiliteitstheorie en de specifieke fase in het leerproces die centraal staat in de cognitieve flexibiliteitstheorie (2.1.3).

\subsubsection{III-structured domains}

De transfer van conceptuele kennis naar uiteenlopende praktijksituaties vormt een nog onopgelost probleem, niet alleen in de lerarenopleiding (Bransford, Derry, Berliner, Hammerness, \& Beckett, 2005). De cognitive flexibility theory (CFT) richt zich op kwesties rondom advanced learning (ter onderscheiding van introductory learning en het leren van experts) en geeft oplossingsrichtingen voor het bereiken van leerdoelen zoals beheersing van complexiteit en transfer van concepten naar nieuwe situaties. Het bevorderen van advanced learning (of diep leren) zou resulteren in het beheersen van concepten en dienen ter voorbereiding op praktisch handelen in 
complexe domeinen. Een belangrijke doelstelling is het aanleren van open kennisstructuren die flexibel kunnen worden toegepast met gevoel voor de specifieke situatie (Jacobson \& Spiro, 1995; Spiro, Collins, \& Ramchandran, 2006, 2007; Spiro, Coulson, Feltovich, \& Anderson, 1988; Spiro, Feltovich, Jacobson, \& Coulson, 1992). Voor een lerarenopleiding is de specifieke aandacht voor de fase van advanced learning van belang aangezien dit het niveau is waarop zij zich richt.

Volgens de CFT wordt de toepassing van concepten en vaardigheden in nieuwe situaties beter geleerd als die concepten en vaardigheden zijn geïntroduceerd vanuit verschillende perspectieven en in verschillende situaties (Derry \& STEP Team, 2003; Derry, Hmelo-Silver, Nagarajan, Chernobilsky, \& Beitzel, 2006; Spiro et al., 1992). Dit geldt in het bijzonder voor advanced learning in zogenaamde ill-structured domains. In dergelijke domeinen volstaat het niet om via de toepassing van vaste procedures en welomschreven concepten tot een zinvolle oplossing van een probleem, of een bepaald type problemen, te komen. Echter, typerend voor een ill-structured domein is dat iedere situatie daarin uniek is en dat per situatie diverse factoren moeten worden afgewogen om tot een zinvolle oplossing en tot adequaat handelen te komen. De CFT beschrijft enerzijds vanuit een ken- en leertheoretisch perspectief waaruit de complexiteit van ill-structured domeinen bestaat en biedt anderzijds vanuit een instructietechnologisch perspectief richtlijnen voor de vormgeving van een instructie waarmee leerdoelen op het gebied van diep leren of cognitieve flexibiliteit worden nagestreefd. Ingegaan wordt eerst op de factoren die kenmerkend zijn voor een illstructured domein. Wat maakt een ill-structured domein complex?

Ill-structured domeinen worden, in termen van Spiro, gekenmerkt door concept complexity, case-complexity en across-case-irregularity (Spiro, Collins, \& Ramchandran, 2007). De concepten die worden gehanteerd bij het analyseren en interpreteren van een situatie zijn niet statisch, maar veranderlijk van aard. Concepten kennen een abstracte inhoud en een zekere reikwijdte: ze betekenen niet altijd precies hetzelfde. Dit wordt concept complexity genoemd. In de concrete situatie hebben concepten steeds, binnen grenzen, een andere en unieke verschijningsvorm. Een metafoor die hiervoor in de CFT wordt gebruikt, is een familiestamboom: de stam wordt gevormd door een concept. Individuele familieleden, gezinnen en familietakken zijn de concrete verschijningsvormen van de familie. Sommige familieleden lijken op elkaar, je ziet ook overeenkomsten tussen bepaalde groepen, maar verre neven kunnen opeens heel nieuwe en verrassende gelaatskenmerken tonen.

Naast deze grillige verschijningsvorm van concepten in concrete situaties, zijn case complexity en across-case-irregularity typerend voor de situaties in een ill-structured domein. Binnen een complexe situatie beïnvloeden verscheidene factoren elkaar, waardoor die factoren een verschillende betekenis of ander relatief gewicht kunnen krijgen. Onder de invloed van een specifieke context ontstaat deze case-complexity. In een vergelijking van situaties kunnen overeenkomsten worden gesignaleerd, maar vanwege de unieke constellatie van factoren in iedere situatie, kan niet een algemeen handelingsvoorschrift of principe worden afgeleid voor een juiste aanpak. De 
uniciteit van iedere situatie leidt tot across-case-irregularity, dat wil zeggen dat situaties onderling niet zonder meer inwisselbaar zijn.

Aangezien bij het analyseren en interpreteren van cases in een ill-structured domein gebruik wordt gemaakt van realistische situaties, is het vrijwel altijd noodzakelijk om concepten uit verscheidene kennisdomeinen te combineren. Het combineren van kennis uit verscheidene domeinen is ook een factor die de complexiteit van situaties in een ill-structured domein bepaalt.

Kortom, een ill-structured domein is complex vanwege de aard van de gehanteerde concepten en de uniciteit van de context die een situatie beïnvloedt. Een goed begrip van complexe praktijksituaties vergt dus flexibiliteit in het toepassen van concepten, met aandacht voor de specifieke context. Een juiste analyse en interpretatie van de situatie komt tot stand op grond van een (deels persoonlijke) inschatting van specifieke contextfactoren. Omdat complexe situaties zelden simpelweg vergelijkbaar zijn met elkaar kan ook geen rechtlijnige procedure worden gevolgd voor het adequaat handelen in een bepaald type situatie.

In de volgende paragraaf wordt nader ingegaan op het onderzoek naar ill-structured problems, omdat dergelijke situaties het hart van de cognitieve flexibiliteitstheorie raken.

\subsubsection{III-structured problems}

De situaties die specifiek zijn voor een ill-structured domein worden gekarakteriseerd als ill-structured problems. Vanuit de cognitieve psychologie, onderwijspsychologie en instructietechnologie is onderzoek gedaan naar de aard van complexe en realistische problemen ofwel zogenaamde ill-structured problems (Jonassen, 1997; Kitchner, 1983; Spiro et al., 1992). Belangrijke algemene kenmerken van ill-structured problems zijn:

- dat ze geworteld zijn in de praktijk en dus contextafhankelijk;

- dat ze meerdere oplossingsmogelijkheden kennen waarvan er niet één per se de beste is;

- dat conflicterende of verschillende perspectieven en belangen een rol kunnen spelen;

- dat vaak integratie van kennis uit verschillende domeinen nodig is om het probleem op te lossen (Jonassen, 1997; Kitchner, 1983).

In tegenstelling hiermee kenmerken de well-structured problems zich door abstractie, afbakening en overzichtelijkheid. Alle benodigde kenniselementen van het probleem zijn bekend en het toepassen van duidelijke concepten en procedures leidt tot bevredigende oplossingen.

Het denken over ill-structured problems is geworteld in verschillende tradities, namelijk in theorie over probleemoplossen, in de cognitieve flexibiliteitstheorie en de daarbij behorende instructietheorie, en in constructivistische leertheorie. De theoretische invalshoeken waarmee ill-structured problems worden benaderd, bevatten leertheoretische en epistemologische aspecten. Chin en Chia (2006) vattten de uitgangspunten voor het oplossen van ill-structured problems als volgt samen: 
The model for solving well-structured problems is based on informationprocessing theories of learning, while the model for solving ill-structured problems relies on (a) the theory of ill-structured problem solving as described above (Jonassen, 1997), (b) cognitive flexibility theory which conveys problem complexity by presenting multiple perspectives and opinions (Spiro et al., 1987, 1988), and on (c) constructivist and situated cognition approaches to learning (Brown et al., 1989). As Roth (1994) pointed out, "From a constructivist view, such [ill-structured] problematic situations provide favorable conditions for learning, because the problem solver is facing conditions for which no known procedures are available". (p. 216)

Het onderscheid tussen well-structured en ill-structured problems is volgens Jonassen (1997) overigens een gradueel verschil: ze vormen geen tegenstelling, maar bevinden zich in een continuüm, van enerzijds gedecontextualiseerde problemen met convergente oplossingen tot anderzijds gecontextualiseerde problemen met divergente oplossingen. Hij ziet een analogie tussen het probleemoplossingsproces van ill-structured problems en het ontwerpproces en beschrijft dit proces in zeven stappen: a) verwoorden van de problem space en de contextuele beperkingen, b) identificeren en verhelderen van diverse opvattingen, posities en perspectieven van belanghebbenden, c) genereren van mogelijke oplossingen, d) beoordelen van de uitvoerbaarheid van de alternatieve oplossingen door argumenten en persoonlijke opvattingen te verwoorden, e) monitoren van de problem space en oplossingsmogelijkheden, f) implementeren en monitoren van oplossing en ( $\mathrm{g}$ ) aanpassen van de oplossing (Jonassen, 1997, p. 78-83).

Een belangrijk element in het probleemoplossingsproces is de eerste stap, het creëren van de problem space. Het probleemoplossingsproces is in eerste instantie afhankelijk van de wijze waarop het probleem wordt gepercipieerd en gerepresenteerd door de probleemoplosser. Begrip van het type probleem, van het doel en van de factoren die een rol spelen bij het oplossingsproces bepalen de zogenaamde problem space. Hoe meer ervaring en kennis iemand heeft, hoe rijker de representatie van een probleem wordt en hoe breder de problem space, zodat passende oplossingen kunnen worden gezocht. Het creëren van de problem space bij ill-structured problems is moeilijk, juist omdat het probleem niet helder gedefiniëerd is, vanuit verschillende perspectieven kan worden benaderd en mede door de context wordt bepaald. Dit vergt van de probleemoplosser het onderzoeken van alle mogelijke oorzaken van het probleem en het in acht nemen van de specifieke contextuele factoren.

Dat ill-structured problems specifieke vaardigheden vergen van de student, wordt duidelijk bij een interpretatieve casestudie van Chin en Chia (2006). Ill-structured problems worden ingezet bij studenten die gewend zijn vooral uit het hoofd te leren en te werken met well-structured problems. Problemen ondervonden de studenten vooral in de fase van het formuleren van de problem space. De ill-structured 
problems leidden vervolgens wel tot het formuleren van persoonlijk betekenisvolle onderzoeksvragen en tot zelfstandig onderzoeken van studenten.

Ill-structured problems zijn niet per definitie moeilijker dan well-structured problems, maar ze vergen wel deels andere probleemoplossingsvaardigheden. Domeinkennis en argumentatievaardigheden zijn factoren die bepalen hoe succescol het probleemoplossingsproces verloopt bij zowel ill- als well-structured problems (Shin, Jonassen, \& MacGee, 2003). Daarnaast vergen de ill-structured problems van de studenten bepaalde metacognitieve vaardigheden zoals plannen, monitoren en evalueren van doelen/oplossingen. Voortdurend moeten immers afwegingen worden gemaakt met betrekking tot de eigen keuzes in relatie tot mogelijke alternatieven en moeten oplossingen worden geëvalueerd. Argumentatievaardigheden zijn van bijzonder belang bij ill-structured problems, aangezien verschillende (soms tegenstrijdige) perspectieven op en persoonlijke interpretaties van het probleem met elkaar in overeenstemming moeten worden gebracht en aangezien de gekozen oplossing verdedigbaar moet zijn in het licht van andere mogelijke oplossingen (Jonassen, 1997; Shin et al., 2003).

Het versterken van probleemoplossingvaardigheden blijkt lastig te zijn. Onderzoek daarnaar focust op verschillende aspecten. De effecten van een specifieke instructiestrategie bijvoorbeeld zijn onderzocht door Ge en Land (2003). Hun onderzoek naar het gebruik van question prompts en peer interactions bij het oplossen van ill-structured problems laten zien dat question prompts een positief effect hebben op probleemoplossingsvaardigheden. Er is ook een indicatie dat peer interaction een positief effect heeft op cognitive thinking en metacognitive skills, mits de peer interaction ondersteund wordt.

Choi en Lee (2009) concentreren zich op het ontwikkelen van een case-based instructiemodel voor het verbeteren van probleemoplossingsvaardigheden. Zij hebben een case-based leeromgeving met scaffolding ontworpen op basis van Jonassens model voor een constructivistische leeromgeving en zijn beschrijving van het probleemoplossingsproces. Er zijn positieve resultaten voor de transfer van enkele subvaardigheden (verscheidene perspectieven innemen en kritisch denken) naar een nieuwe casus gevonden; voor andere subvaardigheden (onder andere argumentatie) bestaat een indicatie voor transfer; voor de subvaardigheid 'linking to theory' is geen significant transfereffect gevonden.

\subsubsection{Advanced learning en transfer}

De cognitieve flexibiliteitstheorie concentreert zich op een specifieke fase in het leerproces; niet op het leren van beginnelingen en niet op het leren van experts, maar juist op het leren van de groep daartussenin: de gevorderde student. De CFT stelt in de fase van het advanced learning het gebruik van ill-structured problems in illstructured domains centraal. Gesignaleerd wordt dat in de onderwijspraktijk vaak gebruik wordt gemaakt van well-structured problems, wat leidt tot gefragmenteerde kennis, een gesimplificeerd beeld van de werkelijkheid en het onvermogen om complexe, realistische problemen op te lossen (Spiro et al., 1992). 
De well-structured, vaak typisch schoolse problemen, zijn geschikt voor inleidingen in een vakgebied om kennis te maken met centrale concepten en ideeën waarbij relatief eenvoudige leerdoelen zoals herkenning en reproductie worden gevraagd (Jones \& Spiro, 1992). Duidelijkheid over de inhoud van de gehanteerde concepten wordt dan op gestructureerde wijze verworven. Voor een eerste inleiding op een vakgebied in een ill-structured domein kan het zinvol zijn concepten en cases niet al te complex voor te stellen. Desalniettenmin blijft het belangrijk om bij een inleiding de zaken niet al te eenvoudig voor te stellen, zodat oversimplificatie en een reductive bias, in de latere fase van advanced learning kan worden voorkomen (Spiro, Feltovich, Coulson, \& Anderson, 1989).

Voor gevorderde studenten is het noodzakelijk dat ze zich uiteenzetten met illstructured problems, omdat die het meest lijken op de situaties die professionals in de praktijk tegenkomen. Jones en Spiro (1992) spreken van een ill-structured knowledge domain, dat wil zeggen een vak- of kennisgebied, waarin zich situaties of (ill-structured) problemen voordoen die vragen om een diep begrip van complexe concepten en contextuele factoren:

At a more advanced stage, however, the students must acquire an understanding which is qualitatively different, involving the application of multiple, interrelated concepts to new, diverse, and largely unexpected circumstances. By contrast with the more well-structured domains of introductory learning, this more advanced stage requires the mastery of 'ill-structured knowledge domains,' in which concepts are more complex and interdependent, involve significant contextdependent variations, and require the ability to respond flexibly to highly diverse and 'messy' situations of application. (p.145)

Het verwerven van diep begrip of diepe kennis is een belangrijke doelstelling in de cognitieve flexibiliteitstheorie. Aangesloten wordt bij onderzoek naar de aard van expertkennis. Experts in een vakgebied beschikken over cognitieve flexibiliteit en zijn daardoor in staat vraagstukken vanuit verschillende invalshoeken te bekijken.

Experts possess cognitive flexibility when they can evaluate problems and other types of cases in their field of expertise from many conceptual points of view, seeing multiple possible interpretations and perspectives. Wiggins and McTighe (1998) argue that understanding complex issues involves being able to explain them in more than one way. Spiro and others (1991) argue that the inability to construct multiple interpretations in analyzing real-world cases can result from instruction that oversimplifies complicated subject matter. (Bransford, Derry, et al., 2005, p. 61-62)

Expertkennis kenmerkt zich door een organisatie in betekenisvolle patronen rondom essentiële vraagstukken in een vakgebied. Ook zijn deze patronen georganiseerd volgens dieperliggende principes, in tegenstelling tot de losse elementen waaruit de kennis van beginnelingen bestaat en de oppervlaktekenmerken op basis waarvan deze 
kennis is georganiseerd (Bransford, Derry, et al., 2005; Bransford, Vye, et al., 2005). Hoe dieper de kennis, hoe moeilijker deze is te beschrijven in een beperkt aantal regels. Het hebben van een diep begrip (understanding) vergt een grondige domeinkennis en kan niet worden geabstraheerd tot algemene cognitieve vaardigheden (zoals toepassen, analyseren, synthetiseren etc.) los van een bepaalde inhoud, zo beweren Bereitner en Scardamalia (1998) in hun kritiek op de klassieke taxonomie van Bloom. Kort samengevat: 'Having a deep understanding of something means understanding deep things about it'(Bereitner \& Scardamalia, 1998, p.682). Deze minimale definitie van deep understanding houdt principieel in dat kennis van een bepaald onderwerp (deep things) noodzakelijk is en dat niveaus in understanding niet domeinoverschrijdend kunnen worden geformuleerd. De cognitieve flexibiliteitstheorie poogt de bovengenoemde kenmerken van de denkwijze van experts bij het benaderen van een probleem of situatie ook te bewerkstelligen bij de gevorderde student en heeft daartoe een instructietheorie ontwikkeld (zie paragraaf 2.4).

Een kanttekening moet overigens worden gemaakt bij het gebruik van de term illstructured domain. Hoewel sommige domeinen per definitie ill-structured zijn en andere niet of minder, wordt het ill-structured karakter van een domein vooral bepaald door het toepassen van kennis op realistische praktijkproblemen. Het domein van de techniek bijvoorbeeld kent een kennisbasis die goedgeordend en duidelijk omschreven is. Echter, bij het oplossen van een technisch probleem, kan blijken dat die kennis niet toereikend is om het probleem op te lossen, omdat andere (context)factoren een rol spelen zoals klimaat, terrein, kosten, beschikbare materialen et cetera (Spiro et al., 1992; Spiro \& DeSchryver, 2009). Zo krijgt een well-structured domain toch trekken van ill-structuredness, met name in de fase van advanced learning. De gradatie waarin vakgebieden gekenschetst kunnen worden als illstructured is echter wel verschillend.

De cognitieve flexibiliteitstheorie streeft naar complexe leerdoelen voor gevorderd leren en zet in op het bereiken van transfer. Het transferprobleem wordt geadresseerd vanuit een constructivistisch en situated knowledge-perspectief. In de traditionele opvatting van transfer, ook wel getypeerd als de direct application (DA) transfertheorie, wordt nagegaan of iemand die 'iets' heeft geleerd ditzelfde kan toepassen op een ander, vergelijkbaar probleem (Bransford \& Schwarz, 1999). Resultaten van onderzoeken naar een dergelijke vorm van transfer zijn teleurstellend, want weinig studies waarin het geleerde direct toegepast moet worden op een transfertaak laten positieve transferresultaten zien. Vanuit het situated knowledgeperspectief wordt transfer op een andere wijze gepercipieerd, omdat uitgegaan wordt van een fundamenteel verschillend idee over kennis. Wezenlijk is het idee dat kennis intrinsiek is verbonden aan de context waarin ze wordt verworven, dat kennis sociaal van aard is en dat authentieke activiteiten noodzakelijk zijn om in een bepaalde (kennis)cultuur 'in te groeien' (Brown, Collins, \& Duguid, 1989). De verwachting dat kennis eenvoudigweg losgemaakt kan worden van de context en toegepast kan worden in een andere context is dan onwaarschijnlijk. Het lijkt, juist met deze situated visie op kennis, dat transfer een onmogelijkheid is. Echter, in plaats 
van transfer af te meten aan de directe toepassing van kennis op een geïsoleerde taak, wordt de focus verschoven van direct application naar preparation for future learning (PFL) (Bransford \& Schwarz, 1999; Bransford, Derry, et al., 2005). Nagegaan wordt daarbij in hoeverre het geleerde leidt tot het vermogen om te leren in een kennisintensieve omgeving, want dat is wat een professional nodig heeft; het gebruikmaken van allerlei bronnen en netwerken bij het oplossen van een authentiek probleem (in tegenstelling tot het geïsoleerd werken aan een transfertaak) zijn daarvan belangrijke aspecten. Dit leervermogen onderscheidt zich overigens van algemene leervaardigheden zoals bij theorieën over leren leren, en behelst juist kennis en vaardigheden die verbonden zijn aan een bepaald kennisdomein; onderzoek laat immers zien dat domeinkennis en vaardigheden onderling afhankelijk zijn (Chi et al., 1988; NRC, 2000 geciteerd in Bransford, Derry, et al., 2005). Schwarz, Bransford en Sears (2005) laten positieve resultaten voor de PFL-vorm van transfer zien.

Een dergelijke vorm van transfer, preparation for future learning, wordt ook beoogd door de cognitive flexibility theory, die immers streeft naar het aanleren van een kennisstructuur die flexibel kan worden toegepast met gevoel voor de specifieke situatie. Deze kennisstructuur vereist het vermogen om nieuwe kennis te integreren in bestaande kennis en leent zich voor uitbreiding in de toekomst. Om een dergelijke kennisstructuur aan te leren, is op basis van de beschreven leertheoretische noties een instructietheorie ontwikkeld waarin het leren van cases centraal staat (Spiro et al., 1992). In paragraaf 2.2 wordt daarom nader ingegaan op de achtergronden van het denken en leren op basis van cases.

\subsection{Denken en leren op basis van cases}

In deze paragraaf ligt de focus achtereenvolgens op de mentale processen die een rol spelen bij het leren op basis van cases, het leren op basis van cases en op de soort kennis die daarmee verworven kan worden. Case-based reasoning, een theorie over cognitie en cognitieve processen, geeft een theoretische onderbouwing voor de wijze waarop mensen leren op basis van cases en verschaft een basis voor het ontwerpen van leeromgevingen. Case-based learning is een werkwijze waarmee beoogd wordt theorie en praktijk nauw met elkaar te verbinden en waarmee gecontextualiseerde kennis wordt verworven.

\subsubsection{Case-based reasoning}

Een theoretische onderbouwing voor het leren van cases wordt gegeven door CaseBased Reasoning (CBR), waarin leren, redeneren en de werking van het geheugen worden verbonden. Case-based reasoning komt voort uit onderzoek naar kunstmatige intelligentie en cognitieve processen (Kolodner \& Guzdial, 2000; Kolodner, Owensby, \& Guzdial, 2004; Kolodner, 2006). Om intelligente systemen te maken werd onderzoek gedaan naar de processen die ertoe leiden dat iets/iemand kan redeneren op basis van eerdere ervaringen in plaats van op basis van regels. Dergelijke systemen zouden meer gelijkenis vertonen met het gedrag van echte experts en ze zouden in de loop van de 
tijd, door het opdoen en leren van ervaringen, competenter worden. Dit onderzoek heeft geresulteerd in een theorie over cognitie en cognitieve processen, onder de naam case-based reasoning (CBR), die verklaart hoe mensen eerder opgedane ervaringen toepassen op problemen in nieuwe situaties.

Concrete ervaringen vormen de basis van CBR, maar abstract denken wordt wel gebruikt om concrete ervaringen productief te maken; abstracties worden gebruikt voor het categoriseren van cases in een case-library, voor het aanleggen van een index-vocabulaire en voor het hanteren van de gedeeltelijke overlap tussen cases.

In CBR staan drie begrippen centraal: casus, case-index en case-processor. CBR gaat ervanuit dat de menselijke geest kennis structureert en in het geheugen opslaat in de vorm van verhalen, met behulp van zogenaamde scripts of cases (Kolodner, 2006). Een casus is een kennisstructuur die gebeurtenissen, volgorde, personen en andere kenmerken van een ervaring representeert. Intelligent gedrag komt tot stand op basis van vergelijking van een script en een nieuwe situatie; intelligent gedrag is namelijk afhankelijk van iemands vermogen om (a) in een nieuwe situatie belangrijke elementen te ontdekken en (b) uit zijn geheugen de best-gelijkende casus op te diepen. Kort gezegd is een casus een interpretatie van een ervaring met diverse componenten zoals een verhaal die heeft. Het interpreteren van een ervaring is een vorm van reasoning. Hoe beter de interpretatie van een casus, dat wil zeggen hoe beter de verklaringen zijn die alle losse onderdelen met elkaar verbinden, hoe bruikbaarder de casus later is. Uit een casus worden lessen getrokken die bij de confrontatie met een nieuwe casus uit het geheugen worden opgeroepen en toegepast. Reasoning vindt dus plaats bij het interpreteren van de diverse componenten binnen een casus, maar ook bij het vergelijkingsproces van de ene casus met de andere.

Essentiëel voor het redeneren is de beschikbaarheid van cases in het geheugen. Het proces waarbij cases worden opgediept uit het geheugen is afhankelijk van de manier waarop een casus is opgenomen in het geheugen ofwel is geïndexeerd. Een goede indexering is belangrijk om cases productief te maken voor verder leren en voor transfer. Een goede indexering maakt een casus namelijk toegankelijk in het geheugen, zodat de lerende op het juiste moment een casus herkent als toepasbaar in een nieuwe situatie. Kolodner et al. (2004) formuleren dit als volgt:

A good indexing scheme for case-based reasoners allows them to see a past situation as relevant to the one now facing them. Thus, a case's indexes should allow us to find it at times when it might be productive to apply it. Good indexes are critical to transfer, the ability to apply knowledge or skills derived in one kind of situation in a situation that might be quite different. (p.831)

Het formuleren van lessons learned uit een casus en het anticiperen op toekomstige toepassingen levert de beste indexen op. Echter, vaak is het onmogelijk om alle mogelijke scenario's waarin het geleerd van toepassing zou kunnen zijn, van tevoren te bedenken en vaak ontbreekt ook de kennis en ervaring om een casus meteen op zijn waarde te schatten. Hoewel de indexering van cases daarom vaak incompleet is, 
wil dat niet zeggen dat de cases daarmee ontoegankelijk zijn. Aanpassing van incompleet of fout geïndexeerde cases vindt plaats via situation assessment, het proces waarbij een nieuwe situatie wordt geanalyseerd en geïnterpreteerd. Dit interpretatieproces leidt met terugwerkende kracht ook tot aanpassing van de indexering van oude cases.

Een aantal geïndexeerde cases tezamen vormt een mentale case library, een verzameling van pregnante situaties die exemplarisch zijn voor onderliggende principes of algemene concepten. Op deze wijze kan de basis van een kennisdomein systematisch worden opgeslagen in het geheugen. Kolodner en Guzdial (2000) benadrukken het belang van een goede indexeringssystematiek voor de lerende die bezig is zijn case library op te bouwen.

De case processor tenslotte is het mechanisme dat ervoor zorgdraagt dat de mentale processen plaatsvinden die leiden tot begrip, indexering, herinnering en toepassing van cases. Het gaat daarbij om cognitieve processen zoals het interpreteren van nieuwe situaties met behulp van relevante andere cases, het beslissen welke oude casus het best toepasbaar is et cetera.

Kolodner en Guzdial (2000) beschrijven het mentale leerproces zoals dat plaatsvindt bij case-based reasoning. Lerenden bestuderen een individuele casus en verbinden de diverse elementen van die casus middels redeneringen tot een plausibel, samenhangend geheel. Na het bestuderen en analyseren van de individuele casus vindt een abstractieproces plaats en wordt de casus geïndexeerd en opgeslagen in het geheugen als een voorbeeld van een onderliggend principe of een lesson learned.

Voor een goede indexering is het handig om te expliciteren wat precies is geleerd en in welke situaties dit in de toekomst nuttig kan zijn. Dit abstractieproces is noodzakelijk om los te kunnen komen van de specifieke ervaringscontext van een individuele casus en maakt transfer van kennis naar andere contexten mogelijk. In een nieuwe situatie wordt de geïndexeerde casus in het geheugen opgeroepen en worden hiermee vergelijkingen getrokken. Het in beschouwing nemen van verschillen en overeenkomsten tussen reeds geïndexeerde en nieuwe situaties leidt tot dieper begrip van die situaties en een genuanceerder beeld van de gehanteerde concepten. Op basis van de vergelijking kan de lerende vervolgens tot een idee komen over welk gedrag passend is in de nieuwe situatie. Het is immers denkbaar dat in de nieuwe situatie een ander gedrag passend is dan in de geïndexeerde casus. Op deze wijze, door het opdoen van ervaringen, indexeren en vergelijken, wordt een case library opgebouwd en verfijnd. Hierbij is een adequate case method (een instructie) die het indexeringsproces ondersteunt, nodig om de mogelijkheden die cases bieden voor het opbouwen van transferabele kennis ten volle te benutten

Een belangrijke opbrengst uit onderzoek naar case-based reasoning is het inzicht dat hoe gedetailleerder een casus wordt onthouden, hoe toegankelijker en bruikbaarder die casus later wordt. En, hoe beter een casus wordt geïnterpreteerd, hoe groter de kans dat een bruikbare, vergelijkbare casus wordt herinnerd om te helpen bij het redeneren (Kolodner, 2006). Als kennis in het geheugen wordt opgeslagen in de 
vorm van cases, dan is het voor de lerende van belang dat hij zich bruikbare, rijke, gedetailleerde cases eigen maakt. Een case-based leertheorie is geformuleerd met vijf centrale uitgangspunten:

- Leren gaat het best in contexten 'trying to achieve goals of interest';

- Om te leren van ervaringen, moeten ervaringen worden geïnterpreteerd en omgevormd tot een duidelijke casus. De toegankelijkheid en bruikbaarheid van de casus worden vergroot naarmate men beter in staat is tot: het verbinden van doelen met het redeneren over het bereiken van die doelen, het expliciteren van leerresultaten, het anticiperen op situaties waarin het geleerde van pas komt, en het expliciteren en het begrijpen van gemaakte fouten;

- Ervaring in toepassing van cases ondersteunt verder leren. Hoe meer gelegenheid te oefenen met cases in nieuwe situaties, hoe beter de interpretaties worden en hoe uitgebreider de kennis en vaardigheden. Van fouten leer je en het levert de mogelijkheid om een oude casus te herinterpreteren;

- Leren vindt plaats met behulp van eigen en andermans cases;

- Leren van fouten gaat het best als onmiddellijk feedback wordt gegeven, zodat reflectie kan plaatsvinden en inzicht kan ontstaan (Kolodner, 2006).

Case-based reasoning (CBR) verschaft een theoretische basis voor onderzoek naar de wijze waarop diepe kennis en expertise ontwikkeld worden via het opdoen van leerervaringen en heeft implicaties voor het ontwerpen van leeromgevingen (Kim \& Hannafin, 2008a). De belangrijkste bevindingen uit een reeks van onderzoeken naar de leeromgeving bij case-based reasoning zijn drieledig. Om het leren van hands-on ervaringen effectiever te maken, moet ten eerste de te leren inhoud meermalen kunnen worden toegepast: oefening en feedback zijn wezenlijk voor het verwerven van diep begrip. Ten tweede moet de lerende via specifieke leeractiviteiten uitgenodigd worden te reflecteren op zijn ervaringen en te expliciteren wat hij leert. Ten derde stelt CBR voor wat betreft het gebruik van leermiddelen dat goed-geïndexeerde case libraries het leren ondersteunen, uitgaand van het idee dat mensen zowel van hun eigen als andermans cases kunnen leren. Voor het leren is niet alleen het gebruik maken van een case library nuttig, ook het zelf produceren van cases is productief:

Building case libraries can be as valuable educationally as using case libraries, as suggested above, sometimes even more valuable than simple use. Students building a case library explicitly have to deal with issues of identifying appropriate indexes, identifying strategies and process elements, and decomposing the case for others to use. By making these activities explicit, the intention is to induce learning goals in the student that are appropriate to generating transferable knowledge (Ram \& Leake, 1995). The activitiy of building a library case is frequently motivating for students (...). (Kolodner et al., 2004, p.834)

Een case library als leermiddel in de leeromgeving kan beschouwd worden als een verzameling verhalen, vormgegeven met uiteenlopende media, die meestal digitaal toegankelijk is. Dit leermiddel kan verschillende functies dienen. Als verzameling 
pregnante situaties die exemplarisch zijn voor onderliggende principes of algemene concepten, kan de case library een kennisdomein vertegenwoordigen. De cognitive flexibility theory werkt met deze functie van de case library en beschouwt het indexsysteem van een domein als een soort advanced organizer die helpt om de belangrijkste issues uit een domein te plaatsen. De cases zelf vormen de bron van kennis en de indexering geeft de lay-out van het domein weer.

Een andere functie van de case library - naast het toegankelijk maken van een domein - is het tonen van de reikwijdte van een concept of de gebruiksmogelijkheden van een vaardigheid. Door verscheidene voorbeelden in het geheugen te hebben van een concept of vaardigheid wordt de betekenis van het concept of de vaardigheid verhelderd, wordt de relatie met andere concepten verhelderd en wordt duidelijk binnen welke grenzen de toepasbaarheid van een concept of vaardigheid zich beweegt. In deze zin kan een case library bijdragen aan het verduidelijken van wat in de CFT concept complexity wordt genoemd (Spiro et al., 1992). Als overige functies van de case library worden genoemd het toegankelijk maken van ervaringen van experts, het tonen van strategieën en procedures voor de aanpak van een probleem en het expliciteren van metacognitieve strategieën zoals het leren hoe je een casus kunt gebruiken in je eigen leerproces (Kolodner, 2006).

\subsubsection{Case-based learning}

Het leren op basis van cases, case-based learning, vindt al decennia lang plaats in het onderwijs - en specifieker in de lerarenopleiding - vanuit de wens om praktijk en theorie nauw met elkaar te verbinden. Aanvankelijk bestond een casus uit een tekst die een realistische situatie uit de praktijk beschreef, later werd de geschreven tekst vaak vervangen door videobeelden en andere digitale media. De werkwijze heeft een vaste plaats verworven in de lerarenopleiding, vanwege de mogelijkheid om gecontextualiseerd te leren en complexe praktijksituaties de opleiding 'binnen te brengen'. Voor studenten werkt het vaak motiverend om realistische en herkenbare situaties, met alle bijbehorende specifieke details, te bestuderen (Kolodner, 2006). Daarnaast is een praktische motivatie voor het gebruik van videocases in de lerarenopleiding van belang. Hoewel Nederlandse studenten relatief veel ervaring opdoen in de beroepspraktijk, komen zij niet met alle relevante situaties in aanraking. Het gebruik van cases biedt in dergelijke omstandigheden een goed alternatief.

Ook in professionaliseringstrajecten voor docenten heeft een werkwijze die de werkplek als uitgangspunt neemt (de authentiekste casus denkbaar), de laatste jaren een sterke voorkeur (van Veen, Zwart, Meirink, \& Verloop, 2010). Het leren op basis van cases biedt de mogelijkheid om de complexe werkelijkheid te laten zien en geen gesimplificeerde of abstracte versie. Met behulp van cases worden concepten ingebed in een realistische en concrete situatie geleerd (Darling-Hammond \& Hammerness, 2002). Studenten bestuderen levensechte situaties en passen theoretische concepten in een analyse toe. Met deze werkwijze worden theorie en praktijk nauw met elkaar verbonden en krijgen theoretische concepten betekenis. 
Shulman benoemt het motiverende en educatieve aspect van werken met cases voor studenten en spreekt van 'a strategy for transforming more propositional forms of knowledge into narratives that motivate and educate', maar hij wijst ook op het potentiële gevaar van 'blijven hangen' bij het ene concrete voorbeeld (Shulman, 1996, p.17). Het voorbeeld gaat dan werken als handelingsvoorschrift voor een categorie van situaties en dat is uitdrukkelijk niet de bedoeling.

In het werk van Choi en Lee (2009) worden diverse onderzoeken aangehaald die suggereren dat case-based learning een effectieve werkwijze is voor het leren oplossen van ill-structured problems, omdat je daarmee een rijke, authentieke context kunt tonen en omdat kennisconstructie op basis van ervaring daarmee wordt ondersteund. Gedecontextualiseerde kennis is niet effectief, want:

- Studenten moeten leren om situational cues te interpreteren, en om principes toe te passen (of aan te passen) op een bepaalde situatie (Johnson, 1988) door ervaring (Ericson, 2003);

- Ill-structured problems worden per definitie beïnvloed door contextuele factoren (Voss, 1987);

- Probleemoplossen berust vaak op case-based reasoning met behulp van opgedane ervaring (Hernandez-Serrano \& Jonassen, 2003);

- Aanleren van probleemoplossend vermogen werkt via het ervaring opdoen met authentieke ill-structured problemen (Bransford 1993) (zoals geciteerd in Choi \& Lee, 2009, p. 104).

Onderzoek naar case-based learning laat zien dat cases onderdeel moeten uitmaken van een case method (een instructie) om daadwerkelijk effectief te zijn (van den Berg, Wallace, \& Pedretti, 2008). Case methods maken het namelijk mogelijk om te switchen van algemene concepten naar specifieke details - en daarmee wordt de mogelijkheid tot het opbouwen van transferabele kennis vergroot. Als cases op een systematische wijze met behulp van een case method worden ingezet in het leerproces, kan worden voorkomen dat de door Shulman gesignaleerde gevaren van gebrek aan abstractie en verzanden in narrativiteit, de overhand krijgen.

\subsubsection{Case-based learning en situated cognition}

Case-based learning brengt studenten in aanraking met realistische problemen en past goed bij zogenaamde situated cognition-perspectieven op kennis en leren. Dergelijke perspectieven hebben hun wortels in een constructivistische opvatting van kennis en leren en hebben een aantal gedeelde centrale aannames, waaronder de idee over de sociale en contextgebonden aard van kennis. Zo wordt aangenomen dat kennis per definitie gesitueerd is in specifieke fysieke en sociale contexten, sociaal van aard is en verspreid is over individuen en leermiddelen (Pieters, 1994; Putnam \& Borko, 1999 ). Brown, Collins en Duguid (1989) stellen dat zowel het leerproces als de conceptuele kennis situated zijn, dat wil zeggen onverbrekelijk verbonden met en gevormd door de omstandigheden en de cultuur waarin zij tot stand komen. Een gevolg van deze opvatting is dat authentieke activiteiten en authentieke contexten een centrale rol krijgen in het leren. Middels het handelen in bepaalde situaties vormt zich de kennis, of anders gezegd, leren is een proces waarbij kennis wordt 
ontwikkeld door de transformatie van ervaring. Case-based leren is een vorm van leren die weliswaar strikt genomen niet plaatsvindt in de authentieke beroepscontext, maar die de authentieke context in ieder geval dicht benadert door realistische problemen te representeren. Verder biedt case-based learning de lerende de mogelijkheid zich actief uiteen te zetten met de gepresenteerde situaties en zijn kennis door middel van analyse, interpretatie en discussie te construeren; kennis die per definitie is gecontextualiseerd.

Verondersteld wordt dat het leren met behulp van cases in dienst kan staan van diverse educatieve doelen, waaronder het onderwijzen van theoretische concepten, het overdragen van morele en ethische waarden en het illustreren van mogelijkheden in de praktijk (Shulman, 1992). Een vraag is nog steeds wat precies wordt geleerd van cases. Voor het benoemen van verschillende typen kennis, worden meerdere categoriseringen gebruikt. Pieters (1994) hanteert het klassieke onderscheid in declaratieve en procedurele kennis en voegt daaraan, mede op basis van epistemologisch werk van Alexander, Schallert en Hare (1991), de categorie 'conditionele kennis' toe. Declaratieve kennis verwijst naar feitelijke of domeinkennis, ook wel aangeduid met 'how it works' of 'knowing what'; procedurele kennis verwijst naar de manier waarop kennis wordt gebruikt, ook aangeduid met 'how-to-do-it' of 'knowing how'; en conditionele kennis verwijst naar de omstandigheden waaronder kennis toepasbaar is, ook aangeduid met 'deciding what to do and when'. Juist deze conditionele kennis wordt volgens inductieve theorieën over kennisverwerving (zoals de cognitieve flexibiliteitstheorie) verworven door de lerende in aanraking te brengen met veel verschillende contexten zoals met case-based learning mogelijk is.

Vanuit een expliciet situated perspectief op kennis en aansluitend bij het klassieke onderscheid tussen declaratieve en procedurele kennis, onderscheiden Kim en (2008b) drie soorten kennis die specifiek van cases kunnen worden geleerd: (a) conceptual case knowledge, (b) strategic case knowledge en (c) socially shared identities and beliefs (Kim \& Hannafin, 2008b, p.1838).

De eerste twee categorieën zijn vergelijkbaar met de eerder genoemde declaratieve en procedurele kennis; de laatste categorie betreft gedeelde opvattingen van de lerende over ( in het geval van docenten) onderwijzen, leren, leerlingen, vakgebieden en zichzelf. Bekend is dat voorkennis en bestaande opvattingen met name bij leraren-inopleiding invloed hebben op wat wordt geleerd (Calderhead, 1996; Ertmer, 2005). De categorie 'conditionele kennis' ontbreekt bij Kim en Hannafin en lijkt impliciet opgenomen in de strategic case knowledge; zij leggen de focus meer op de wijze waarop en de sociale context waarin kennis wordt verworven, sluiten nauw aan bij situated cognition-opvattingen (Brown et al., 1989; Lave \& Wenger, 1991) en betrekken hun indeling op teacher knowledge. 


\subsection{Leren met video en rich media-cases}

De kracht van case-based learning is toegenomen met de introductie van video en andere (digitale) middelen, omdat videocases een hoge mate van authenticiteit, levendigheid, rijkdom en detail kunnen tonen: een realistische situatie kan immers compleet, inclusief non-verbale communicatie, in beeld worden gebracht (Borko, Jacobs, Eitelborg, \& Pittman, 2008; Brophy, 2004; Putnam \& Borko, 2000; Santagata, 2009). Ook in de cognitieve flexibiliteitstheorie wordt gebruik gemaakt van videocases. Deze paragraaf gaat eerst in op de rol van video bij het leren van leraren. Vervolgens wordt ingegaan op verschillende soorten videocases in relatie tot mogelijke leerdoelen en op het begrip rich media-case.

\subsubsection{Leren met video}

In recent onderzoek wordt het leren van leraren met behulp van video vanuit verschillende invalshoeken belicht. Zo laten Van Es en Sherin in een reeks publicaties zien hoe het gebruik van videobeelden in een programma voor professionele ontwikkeling van leraren bijdraagt aan het ontwikkelen van een professional vision ofwel een professionele kijk op classroom interaction, en aan het vermogen om belangrijke zaken op te merken: learn to notice (Sherin \& Han, 2004; Sherin, Linsenmeier, \& Van Es, 2009; Van Es \& Sherin, 2002, 2008, 2010). Op basis van onderzoek naar de kijkwijze van ervaren leraren, wordt gesteld dat de vaardigheden 'opmerken en interpreteren van situaties in de klas' typerend zijn voor ervaren leraren. Leraren-in-opleiding en beginnelingen merken minder op en zijn minder in staat betekenis te geven aan situaties in de klas. Het expliciet opmerken van belangrijke situaties of elementen in een situatie, is voorwaardelijk om te kunnen kiezen voor verandering van gedrag. In het licht van kennis over ervaren leraren, is het learn to notice-framework opgebouwd uit drie wezenlijke vaardigheden:

a) identifying what is important in a teaching situation;

b) using what one knows about the context to reason about a situation; and

c) making connections between specific events and broader principles of teaching and learning (Van Es \& Sherin, 2008, p.245; cf. Van Es \& Sherin, 2002, 2010).

Niet alleen weten ervaren leraren de belangrijke elementen te destilleren uit een situatie, zij gebruiken ook gedetailleerde kennis uit de context bij het interpreteren van situaties. En bovendien beschrijven ervaren leraren situaties die zij observeren met behulp van algemenere termen, zoals 'dit is een toetsings-issue'. Daarmee wordt geabstraheerd van de specifieke context naar een algemener principe. Gesteld wordt dat videobeelden bij uitstek geschikt zijn voor het ontwikkelen van de reflectieve en analytische vaardigheden die bij learn to notice horen. Het gebruik van videobeelden biedt immers de mogelijkheid stil te staan bij situaties in de klas en in alle rust de situatie onder de loep te nemen en meermalen te bekijken (Sherin \& Han, 2004). Onderzocht is de videoclub als model voor de professionele ontwikkeling van leraren (Van Es \& Sherin, 2008, 2010). Het doel is om videobeelden uit de eigen 
praktijk kritisch te leren beschouwen, interpreteren en betekenis te geven. In de videoclub bekijken en bediscussiëren leraren videobeelden van elkaars onderwijspraktijk. Gebleken is dat deelname aan een dergelijke videoclub het denken en handelen van leraren beïnvloedt, waarbij vooral opvallend is dat de leraren meer aandacht gaan besteden én meer belang hechten aan het wiskundig denken van de leerlingen, zowel in de discussie van de videobeelden als in hun eigen onderwijspraktijk. Ook verschuift de focus in hun analyses van beoordelend en beschrijvend naar meer interpretatief. Dit onderzoek laat zien dat het leren met behulp van video interessante mogelijkheden biedt voor het ontwikkelen van een professional vision waarbij leraren situaties analytischer en betekenisvoller leren bekijken en bediscussiëren. Hoe de ontwikkeling van learn to notice-vaardigheden en een profesional vision bij een andere doelgroep, namelijk leraren-in-opleiding, ondersteund kan worden, is in deze serie studies niet onderzocht.

Verscheidene onderzoeken laten overigens zien dat leren met behulp van video kan bijdragen aan het verhogen van de kwaliteit van analyse en reflectie (Borko, Jacobs, Eiteljorg \& Pittman, 2008; Rosaen, Lundeberg, Cooper, Fritzen, \& Terpstra, 2008; Zhang, Lundeberg, Koehler \& Eberhardt, 2011). Aansluitend bij het onderzoek naar de effecten van videoclubs, is het werk van Borko et al. (2008) waarin positieve effecten worden gerapporteerd over de ontwikkeling van analytische en interpretatieve vaardigheden (productive discourse) van leraren die videobeelden van elkaars onderwijspraktijk bediscussiëren. Deze discussies werden in de loop van twee jaar productiever, "that is, the teachers talked in a more focused, in-depth, and analytical manner about specific issues related to teaching and learning in the selected mathematical problem" (Borko et al., 2008, p.432). Bij de gehanteerde aanpak heeft de facilitator een belangrijke taak in het bepalen van de analytische focus, het selecteren van de te bediscussiëren videoclips en het sturen van de conversatie. Dit onderzoek levert aanwijzingen op voor het idee dat professionele ontwikkeling met gebruikmaking van video-opnamen uit de eigen praktijk, effectiever wordt door een vorm van sturing en planning en het werken met gestructureerde analytische taken. In het onderzoek van Zhang et al. (2011) wordt een onderscheid gemaakt tussen het gezamenlijk en individueel bekijken van videobeelden van de eigen onderwijspraktijk en wordt geconstateerd dat beide kijkwijzen een eigen functie hebben in de reflectie en analyse. Het gezamenlijk bekijken van videobeelden leidt tot comparatieve reflectie, waarbij alternatieve gezichtspunten en verschillende perspectieven in acht worden genomen. Individueel bekijken van video leidt daarentegen tot descriptieve en kritische reflectie, waarbij op grond van doordachte overwegingen een oordeel wordt gegeven over toekomstige handelingen. Vooral de mogelijkheid tot herhaald bekijken van de video helpt leraren meer te zien dan aanvankelijk het geval was. De studie beveelt aan om leraren zelf de controle te geven over de video-opnamen van hun onderwijspraktijk en hen zelf geschikte videoclips te laten selecteren voor discussie.

Enkele studies naar het leren met behulp van video richten zich op een andere doelgroep, namelijk op de leraren-in-opleiding (Rosaen et al., 2008; Stockero, 2008; 
Yerrick, Mosh, \& Molebash, 2005). Het ontwikkelen van reflectieve en analytische vaardigheden is ook in de lerarenopleiding van groot belang en de mogelijkheden van video worden hierbij in toenemende mate onderkend. Het observeren van videobeelden van de eigen onderwijspraktijk leidt bijvoorbeeld tot reflectie met specifiekere commentaren op het eigen onderwijsgedrag dan bij reflectie zonder video; in de op video gebaseerde reflectie verschuift de focus van klassenmanagement naar instructie en wordt meer gefocust op leerlingen dan op zichzelf (Rosaen et al., 2008). Stockero (2008) laat ook een verschuiving zien: de studie laat zien dat de reflectie van leraren-in opleiding door het werken met een video-based curriculum van hoger niveau werd, dat ze meer bewijs aanvoerden voor hun analyses en dat hun focus gericht werd op het leren van leerlingen. De studie geeft tevens een indicatie dat er transfer plaatsvindt: de leraren-in-opleiding werden ook reflectiever en analytischer ten opzichte van hun eigen lesgeven, hoewel de niveauverschillen in reflectie en analyse groot waren.

De mate waarin leraren-in-opleiding actief betrokken zijn bij het maken van de videobeelden lijkt ook van invloed te zijn op het leerproces. Het zelf maken en editen van videocases is effectiever voor reflectie op de eigen onderwijspraktijk en het leren van leerlingen dan het bekijken van voorgeselecteerde clips (Yerrick et al., 2005). Zij sluiten daarmee aan bij de aanbevelingen van Zhang et al. (2011).

Uit de verschillende studies wordt duidelijk dat de mogelijkheden van het leren met behulp van video interessant zijn. Het middel is geschikt om analytische en reflectieve vaardigheden van zowel ervaren leraren als leraren-in-opleiding te vergroten, leidend tot de ontwikkeling van een professional vision en een professioneler discours ofwel tot diepergaande discussies: er wordt analytischer en beter geargumenteerd met argumenten die gebaseerd zijn op zichtbaar gedrag (in de video) in plaats van op oordelen. Dit gaat gepaard met een inhoudelijker focus op het lesgeven en het leren van de leerlingen.

Naast deze positieve aspecten, zijn er ook kritische punten te noemen die duidelijk maken dat het leren van videobeelden niet probleemloos is. Onderzoek wijst bijvoorbeeld ook uit dat studenten videobeelden van hun eigen onderwijspraktijk oppervlakkig analyseren (Stockero, 2008) en dat studenten oppervlakkig kijken als ze weinig richtlijnen krijgen (Calandra, Gurvitch, \& Lund, 2008); dat ervaren leerkrachten geneigd zijn te sympathiseren met collega's en weinig kritisch te zijn (Borko et al., 2008) en dat leerkrachten zich onprettig kunnen voelen bij het tonen van hun eigen werkwijze aan anderen (Sherin \& Han, 2004).

Er zijn ook nog veel vragen en onduidelijkheden met betrekking tot het leren van video, bijvoorbeeld over de manier waarop van verschillende soorten video wordt geleerd, de verschillende rollen die video kan spelen voor ervaren leraren en lerarenin-opleiding en de manier waarop de instructie en leeromgeving het best vormgegeven kunnen worden voor een effectief leerproces. Gewaarschuwd wordt voor de bijzonder overtuigende werking van videocases en gewezen wordt op de verschillende culturele en persoonlijke referentiekaders waarmee mensen naar videobeelden kijken, wat veroorzaakt dat zij verschillende zaken waarnemen (Miller 
\& Zhou, 2007). Duidelijk is dat voor het leren met behulp van video een case method waarbij de videobeelden in het geheel van de leeromgeving en de instructie een duidelijke plaats krijgen, onontbeerlijk is (van den Berg et al., 2008; Borko et al., 2008).

\subsubsection{Soorten video- en rich media-cases}

Wat en hoe mensen leren van video wordt bepaald door de manier waarop videocases worden ingezet in het leerproces en door de potentie tot leren die verschillende soorten videocases bieden. Verschillende soorten videocases kunnen worden ingezet voor verschillende soorten activiteiten en leerdoelen. Bij de categorisering van videocases lopen soorten videocases en leerdoelen vaak door elkaar.

Videocases kunnen worden gedefiniëerd naar de maker of de gefilmde persoon, waarbij meestal drie categorieën worden onderscheiden: published video, peers' video en own video (Zhang et al., 2011). De eerste categorie videobeelden, met een onbekende maker, wordt ook aangeduid met termen als geproduceerde video of designed video (Schwarz \& Hartmann, 2007) en verwijst daarmee naar de wijze waarop het product tot stand is gekomen en impliciet naar de bedoeling van het product: het is geen rechttoe rechtaan opname van een realistische situatie, nee, de video is ontworpen en bewerkt op basis van bepaalde didactische inzichten om als leermiddel te kunnen dienen. Categorie twee betreft videobeelden van de praktijk van collegae (of medestudenten) en categorie drie van de lerende zelf.

Videocases kunnen ook worden gedefiniëerd naar de inhoud. Termen als exemplary, model of good practice verwijzen dan naar het navolgenswaardige gedrag dat in de video wordt getoond. Ook begrippen zoals authentiek en realistisch horen hier thuis, verwijzend naar de aard van de opgenomen situatie (die dus niet fictief is); ten slotte zijn termen als dilemma-focused, trigger en trailer in gebruik die aangeven dat de opgenomen situatie een dilemma uit de beroepspraktijk betreft, een opmerkelijke situatie is die de tongen voor discussie losmaakt (trigger) of een algemenere introductie geeft op een domein, zoals een trailer bij een film.

Videocases kunnen ten slotte worden gedefiniëerd naar het didactische doel dat ermee wordt beoogd. Door Merseth (1996) worden in hoofdlijnen drie soorten doelen onderscheiden. Een videocasus (a) bevat een goed voorbeeld dat navolging verdient, (b) bevat een onderwerp dat de moeite waard is om te analyseren en te bediscussiëren of (c) dient als middel om te reflecteren op eigen handelen.

Vanuit een iets andere invalshoek onderscheidt Wallace (2002) het primaire, secundaire en tertiaire gebruik van cases, daarbij onder andere verwijzend naar de rol van de lerende. Die loopt uiteen van het zelf produceren van een videocasus (primair gebruik), via het analyseren en interpreteren van een casus (secundair gebruik), tot het bediscussiëren van en reflecteren op een casus (tertiair gebruik). Bij ieder type gebruik horen bepaalde leerdoelen en bepaalde soorten videocases die het meest geëigend zijn voor het bereiken van die leerdoelen. Zo wordt bij het secundaire gebruik van videocases vaak gebruik gemaakt van exemplary cases (met name in de context van de lerarenopleiding), terwijl bij het tertiaire gebruik triggers en dilemmafocused video's centraal staan. 
Schwarz \& Hartmann (2007) beperken zich tot het educatieve gebruik van designed video en geven richtlijnen voor het ontwerpen van een effectieve videocasus. Ze benadrukken dat veel verschillende manieren van leren mogelijk zijn met video, maar dat de ontwerper een duidelijk doel voor ogen moet hebben. Zij stellen een model voor dat uitgaat van de beoogde leerresultaten van een videocasus (ingedeeld in vier algemene klassen, namelijk seeing, saying, engaging, doing), waaraan vervolgens passende videogenres en toetsvormen worden verbonden.

De diversiteit van aanduidingen voor verschillende typen video en het gebruik ervan in educatieve contexten leidt in deze studies niet tot elkaar uitsluitende categorieën. Voor de duidelijkheid is het van belang in elk onderzoek steeds precies aan te geven om welke vorm van video het gaat en hoe en met welk doel deze wordt ingezet in het leerproces.

Tot nu toe is steeds gesproken van videobeelden of videocases. Echter, om de educatieve mogelijkheden van video ten volle te benutten is het zinvol de video te plaatsen in een groter geheel en niet als losstaand leermiddel te gebruiken. Om het leerproces te ondersteunen kunnen digitale videobeelden in een hypermediaomgeving worden bewerkt en gelinkt aan andere media zoals beeld, geluid, tekst, websites et cetera. Met deze aanvullende media wordt de video in een breder perspectief geplaatst en wordt noodzakelijke context- en achtergrondinformatie gegeven. Een dergelijk opgebouwde casus wordt aangeduid met de term multimediacasus (Blijleven, 2005) of rich media-casus. In paragraaf 2.2 is al een inhoudelijk kenmerk genoemd van een casus, namelijk dat zij een representatie vormt van een realistische situatie uit de beroepspraktijk. Dit inhoudelijke kenmerk geldt onverkort voor de videoversie van een casus. Daaraan kan worden toegevoegd dat een casus een didactisch doel dient en tot stand komt door bewuste keuzes te maken in de videobeelden zelf, de aanvullende materialen en de didactische aanpak (van den Berg et al., 2008; Schwarz \& Hartmann, 2007; Wallace, 2002 ). In dit onderzoek wordt het begrip videocasus gehanteerd om een geproduceerde casus aan te duiden die een didactisch doel dient en waarin een digitale video een centraal element vormt dat aangevuld en omlijst wordt met andere digitale en analoge middelen.

\subsection{I nstructie op basis van de cognitieve flexibiliteitstheorie}

In deze paragraaf wordt beschreven welke uitgangspunten kenmerkend zijn voor een instructie die is gebaseerd op de cognitieve flexibiliteitstheorie. Een wezenlijk element hierin vormt het gebruik van videocases.

De CFT is een theorie over 'advanced knowledge acquisition in ill-structured domains' en wil voor de gevorderde student een brug slaan naar de flexibele denkwijze van een expert. Zij baseert zich erop dat de kennis van experts anders is georganiseerd dan die van beginners; kennis van experts is verweven met en gevormd door diverse praktijksituaties en is niet georganiseerd in simplificerende (hiërarchische) structuren. Experts hebben de beschikking over meer en rijkere cases 
(dan beginnelingen) én deze cases hebben onderling veel genuanceerde verbindingen. CFT stelt een instructiewijze voor die de complexe relaties tussen conceptuele kennis en praktijksituaties benadrukt en stelt leren met behulp van videocases centraal. De hypothese is dat de ontwikkeling van een (op die van experts gelijkende) flexibele denkwijze en aanpak van problemen, versneld wordt door een effectieve vorm van case-based instructie. Om de kans op transfer zo groot mogelijk te maken, werkt de student aan het opbouwen van een case library, omdat de kennis immers in de voorbeelden zit vervat.

In an ill-structured domain, wide-scope generalization is not possible - in principle (that's what makes it an ill-structured domain). In the absence of general principles or schemas to guide knowledge application, transfer depends on having a rich store of experiences that capture the variety of ways in which both events in a domain happen and concepts in a domain combine. Rather than acquiring knowledge from examples (as in well-structured domains), the knowledge is in the examples. (Spiro et al., 2007, p. 96)

De op CFT geïnspireerde instructie kent twee essentiële uitgangspunten: (a) het bestuderen van centrale concepten door middel van verscheidene videocases van realistische situaties; (b) het interpreteren van complexe videocases met behulp van concepten uit verschillende domeinen (Derry \& STEP Team, 2003 ). Gesteld wordt dat studenten voor het opbouwen van een case library met zoveel mogelijk verschillende situaties in aanraking moeten worden gebracht. Dat leidt namelijk tot het 'fijnslijpen' van concepten. Bovendien wordt gesteld dat het verwerven van diepe kennis tot stand komt door cases diepgaand te bestuderen - met expliciete aandacht voor het gebruik van kennis uit verschillende domeinen zodat een situatie met verschillende perspectieven wordt geïnterpreteerd.

Daarnaast wordt opgemerkt dat moderne technologie een ideaal hulpmiddel vormt voor het creëren van een leeromgeving waarin non-lineaire strategieën gehanteerd kunnen worden (Siegel et al., 2000; Spiro, Collins, Thota, \& Feltovich, 2003; Spiro et al., 2006, 2007). De wijze waarop de uitgangspunten worden vormgegeven in een instructieontwerp kan verschillen en is afhankelijk van het domein en de specifieke kenmerken van de context waarin wordt geleerd. Positieve resultaten met betrekking tot de ontwikkeling van diepe kennis worden onder andere gerapporteerd in onderzoek waarin een blended leeromgeving is ontworpen met on-line videocasestudie in combinatie met collaboratief leren (Derry, Hmelo-Silver, Nagarajan, Chernobilsky, \& Beitzel, 2006). Met behulp van digitale cognitive tools wordt de analyse van videocases verbonden aan conceptuele kennis, waarbij studenten in een online leeromgeving collaboratief werkten.

De CFT onderbouwt de inzet van het specifieke middel video voor het bevorderen van deep learning en het verwerven van transferabele kennis in ill-structured domeinen vanuit een leertheoretisch perspectief (Spiro et al., 2007). Met name het integreren van video en andere media in rich media-cases biedt mogelijkheden voor 
het aanleren van de beoogde leerdoelen en voor het versnellen van het leerproces. Genoemd werden al de authenticiteit en levendigheid van de videocasus ten opzichte van de geschreven casus. Een extra voordeel van rich media-cases ligt in de mogelijkheid om de werkelijkheid nog gedetailleerder te representeren. Teksten, links, meer camerastandpunten en commentaren kunnen worden toegevoegd aan het videobeeld om nog meer informatie over de situatie te presenteren.

Een belangrijk doel van de CFT is het aanleren van een open, kritische blik en het afleren van oversimplificatie. Om te voorkomen dat de student gemakkelijk over bepaalde elementen in een videocasus heenkijkt, kan de aandacht worden gefocust door diverse bewerkingen zoals desintegratie van het beeld, pijlen in het beeld, omcirkelingen van beeldelementen en voice-overs.

Een tweede belangrijk leerdoel is 'contextgevoelig denken', waarbij het van belang is de reikwijdte van concepten te begrijpen. Video is bij uitstek geschikt om dit te leren. Immers, je kunt - ook tegelijkertijd - diverse situaties tonen waarin een bepaald concept 'verschijnt'. Zo ervaart de student onmiddellijk dat een concept niet op één manier in de werkelijkheid vorm krijgt, maar zich, afhankelijk van de context, in verschillende gedaantes voordoet. Metadatering van videoclips draagt ook bij aan de mogelijkheid om je kriskras door verschillende videocases te bewegen. Hierdoor hoeft video niet alleen als lineair medium bestudeerd te worden en is het mogelijk om zelfstandig verbanden te zoeken tussen clips en concepten in verschillende contexten. Door middel van het bestuderen van videocases komt een student in relatief beperkte tijd in aanraking met een relatief grote hoeveelheid realistische situaties. Het opbouwen van een case library zoals Kolodner en Guzdial (2000) beschrijven, vindt daardoor efficiënt plaats en dit bevordert de mogelijkheid voor de transfer van kennis. Immers, in een ill-structured domein zit de kennis ín de voorbeelden. Hoe meer cases geïndexeerd in het geheugen zijn opgeslagen, hoe meer mogelijkheden iemand heeft om nieuwe situaties daaraan te toetsen.

Om de transfer van kennis te maximaliseren, is het zinvol om gebruik te maken van zogenaamde rich cases: complexe videocases die rijk aan informatie zijn. Als deze cases diepgaand worden bestudeerd, maken studenten zich op een efficiënte wijze de essentiële kenmerken van een ill-structured kennisdomein eigen. Bovendien kunnen videocases herhaald worden bekeken. Het herhaald bekijken van een video leidt ertoe dat een student uiteindelijk maar een paar seconden van een video hoeft te zien om meteen te weten hoe het verder gaat. Dit effect van de overlearned video, werkt positief op de vorming van een case library.

Uit onderzoek blijkt dat het normaliter ongeveer tien jaar duurt om in de beroepspraktijk een expert leraar te worden (Berliner, 2001). Er is immers tijd voor nodig om met allerlei verschillende situaties in aanraking te komen - en de beroepspraktijk biedt bovendien niet altijd de mogelijkheid om met diverse situaties in aanraking te komen. Echter, de CFT beoogt door het werken met complexe en compacte videocases en het herhaald bekijken van die cases dit leerproces efficiënter te laten verlopen en daardoor te versnellen. 


\subsection{Betekenis voor het ontwerp}

In de vorige paragrafen is het theoretische kader geschetst waarbinnen het onderzoek in dit proefschrift plaatsvindt. In de literatuurstudie is ingegaan op de cognitieve flexibiliteitstheorie, de achtergronden van case-based learning en de mogelijkheden van het leren met videocases. In deze slotparagraaf worden eerst worden de belangrijkste elementen uit de literatuurstudie samengevat. Daarna worden ontwerprichtlijnen geformuleerd voor een instructie op basis van de inzichten uit de cognitieve flexibiliteitstheorie.

\section{Samenvatting}

De CFT richt zich op het leren van de gevorderde student en streeft naar het bereiken van complexe leerdoelen in ill-structured domeinen. Een algemene doelstelling is het verwerven van transferabele kennis om realistische (en ill-structured) problemen op te lossen op een wijze die gelijkenis vertoont met de aanpak van experts. Het toepassen van concepten uit diverse domeinen en de sensitiviteit voor de specifieke context zijn typerend voor de nagestreefde cognitieve flexibiliteit. De variabele verschijningsvorm van concepten, de manier waarop concepten onderling samenhangen in een specifieke context, de ongelijkheid van de cases én de noodzaak tot het combineren van concepten uit verschillende kennisdomeinen zijn factoren die gezamenlijk de complexiteit van situaties in een ill-structured domein bepalen.

Realistische problemen uit de beroepspraktijk kunnen goed worden gerepresenteerd in de vorm van cases. Een theoretische onderbouwing voor de cognitieve processen die plaatsvinden bij het leren op basis van cases, wordt gegeven door case-based reasoning (CBR). Met de inzet van cases in het leerproces, kortweg genoemd casebased learning, wordt beoogd theorie en praktijk nauw met elkaar te verbinden, leidend tot het verwerven van gecontextualiseerde kennis.

Vanuit cognitief oogpunt zijn cases een veelbelovend middel om praktisch handelen en conceptuele kennis met elkaar te verbinden, mits gebruik wordt gemaakt van een passende case method. Onderzoek naar het gebruik van videocases voor het leren van leraren laat zien dat videobeelden kunnen bijdragen aan het ontwikkelen van een professionele blik en het ontwikkelen van analytische en reflectieve vaardigheden van zowel ervaren leraren als studenten. De CFT veronderstelt dat de inzet van videocases, gecombineerd met andere digitale en analoge middelen tot rich media-case, bijdraagt aan een effectief leerproces.

\section{Ontwerprichtlijnen}

Op basis van de CFT kan een aantal algemene richtlijnen worden geformuleerd voor het ontwerp van leeromgevingen en instructie. Deze ontwerprichtlijnen vinden deels ook een verklaring in de theorie van case-based reasoning. Typerend voor het ontwerp van CFT-instructie is:

- Gebruik maken van realistische situaties (Derry \& STEP Team, 2003; Kolodner, 1996; Spiro et al., 1992). Realistische situaties benaderen de complexiteit van de praktijk het dichtst en werken motiverend; 
- Centrale concepten van een domein bestuderen in diverse contexten (Derry \& STEP Team, 2003; Kolodner, 2006; Spiro et al., 1992). Het begrip van concepten komt tot stand door studenten met zoveel mogelijk verschillende situaties in aanraking te brengen. Herhaaldelijke toepassing leidt namelijk tot het fijnslijpen van concepten (cf. concept complexity). CBR verklaart dit ook als een verfijning van de scripts;

- Cases interpreteren met behulp van concepten uit verscheidene domeinen (Derry \& STEP Team, 2003; Siegel et al., 2000; Spiro et al., 1992). Het begrijpen en oplossen van een praktijkprobleem vraagt vrijwel altijd om het combineren van kennis uit verschillende domeinen en het betrekken van contextinformatie;

- Diepgaand bestuderen van een beperkt aantal rijke videocases (Derry et al., 2006; Spiro et al., 2007). Het leerproces verloopt effectief en efficiënt als het aantal te bestuderen cases wordt beperkt. Het verwerven van diepe kennis komt tot stand door cases die rijk aaninformatie zijn diepgaand te bestuderen. Video is bij uitstek geschikt voor de representatie van rijke cases. In CBR wordt beweerd dat hoe gedetailleerder een casus is bestudeerd en hoe beter de samenhang tussen de elementen is beredeneerd, hoe beter hij wordt opgenomen in het geheugen en kan worden opgeroepen op een geschikt moment voor vergelijking met een nieuwe situatie.

De vier ontwerprichtlijnen worden ondersteund door inzichten uit het gedachtengoed van case-based reasoning die erop zijn gericht het leren van ervaringen effectiever te maken:

- Te leren inhoud dient meermaals te worden toegepast; oefening en feedback zijn wezenlijk voor het verwerven van diep begrip;

- Gebruik maken van leeractiviteiten om reflectie op ervaringen te stimuleren en om te laten expliciteren wat is geleerd, is belangrijk voor het opbouwen van een case library. 


\section{HOOFDSTUK 3}

\section{Ontwerp van curriculum en instructie}

\section{Inleiding}

In dit hoofdstuk wordt het ontwerp van een interventie beschreven voor het domein communicatie met ouders. Het doel van de interventie is om een leerproces te bevorderen waarin conceptuele kennis op betekenisvolle wijze wordt verbonden aan het analyseren van en professioneel handelen in complexe praktijksituaties. De interventie bestaat uit een vierdelig curriculum en een instructie, waarin het gebruik van videocases en een conceptuele structuur centrale elementen zijn. Het is de bedoeling dat de interventie wordt opgenomen in het bestaande, reguliere curriculum van een lerarenopleiding voor basisonderwijs en een reëel probleem oplost. De combinatie van ontwerprichtlijnen die voortkomen uit de cognitieve flexibiliteitstheorie enerzijds en randvoorwaarden die voortkomen uit de context anderzijds, stelt de ontwerper voor keuzes. De wijze waarop de in hoofdstuk 2 geformuleerde ontwerprichtlijnen zijn geconcretiseerd in het ontwerp van de interventie, wordt in dit hoofdstuk in beeld gebracht.

In paragraaf 3.1 worden eerst het raamwerk beschreven waarbinnen de interventie zich beweegt. De randvoorwaarden en de ontwerprichtlijnen worden beschreven en het domein communicatie wordt geplaatst in de cognitieve flexibiliteitstheorie. Vervolgens worden de kernelementen van het curriculumontwerp en het instructieontwerp beschreven in paragraaf 3.2 en 3.3.

\subsection{Raamwerk}

De literatuurstudie in hoofdstuk 2 heeft vier ontwerprichtlijnen opgeleverd voor het ontwerp van een interventie die cognitieve flexibiliteit bevordert. In het curriculumontwerp worden de eerste drie ontwerprichtlijnen geconcretiseerd, in het instructieontwerp wordt ontwerprichtlijn 4 geconcretiseerd.

De randvoorwaarden waarbinnen de interventie zich beweegt betreffen de aard van het onderwijs, de hoeveelheid beschikbare tijd in het curriculum en de inpassing in het bestaande curriculum. De interventie wordt geacht:

- te passen in een competentiegerichte visie op onderwijs;

- aan te sluiten bij de kenmerken van de verschillende opleidingsfasen in het curriculum. Hierbij moet onder andere gedacht worden aan het betrokkenheidsmodel van Van den Berg en Vandenberghe (1995), vastgestelde doelen per opleidingsfase, een toenemende mate van zelfstandigheid van de student en een nauw verband tussen het onderwijs op de hogeschool en in de beroepspraktijk; 
- te functioneren binnen beperkingen in studiepunten en contacttijd. In het geheel betreft het 8 studiepunten.

Communicatie met ouders wordt in dit onderzoek gekarakteriseerd als een illstructured domein met als kenmerken concept complexity, case complexity en across-case-irregularity (Spiro et al., 1992; Spiro et al., 2007; zie ook hoofdstuk 2). Alle professionele domeinen zijn volgens Spiro en De Schryver (2009) in zekere mate ill-structured en communicatie voldoet bij uitstek aan de kenmerken hiervan. Met een voorbeeld uit het communicatiedomein wordt dit geïllustreerd, te beginnen met concept complexity.

Een concept uit de communicatiekunde is de relationele boodschap. Uit dit aspect van communicatieve uitingen kan opgemaakt worden hoe een zender tegenover een ontvanger staat. Gebleken is dat ontvangers van een boodschap zeer gevoelig zijn voor de toon en wijze waarop een zender de inhoud overbrengt. Niet zozeer het wat, maar vooral het hoe bepaalt de effectiviteit van communicatie. De abstracte inhoud van dit concept kan geleerd worden. Echter, de wijze waarop een relationele boodschap in een daadwerkelijke communicatieve situatie wordt vormgegeven, is altijd, binnen bepaalde grenzen, verschillend, omdat communicatieve situaties zich nooit precies herhalen. Een concept kent zoveel verschijningsvormen als er communicatieve situaties zijn.

Behalve van deze concept complexity is in het communicatiedomein ook sprake van case complexity: realistische en complexe communicatieve situaties zijn uniek vanwege de interactie van verschillende factoren. Zo kan in bepaalde communicatieve situaties de relationele boodschap juist van ondergeschikt belang zijn - in tegenstelling tot wat normaliter het geval is. Een voorbeeld van zo'n geval is de communicatie in een noodsituatie. Dan is het allerbelangrijkst dat de inhoud van de boodschap ('Sluit deuren en ramen') eenduidig overkomt en de relationele boodschap is dan van ondergeschikt belang. Door de specifieke invloed van de context, ontstaat deze case-complexity en de daarmee gepaard gaande ongelijkheid van de cases, across-case-irregularity.

Voor een goed begrip van realistische communicatieve situaties met ouders in het onderwijs is verder de toepassing van conceptuele kennis uit verschillende vakgebieden zoals de pedagogiek en communicatiekunde vereist. Daarnaast vergt de interpretatie van communicatieve situaties aandacht voor de specifieke context en moet die contextinformatie worden betrokken in de afwegingen. Op grond van deze kenmerken wordt communicatie met ouders beschouwd als een ill-structured domein. In dit onderzoek wordt cognitieve flexibiliteit opgevat als 'beredeneerd professioneel handelen'. Om cognitieve flexibiliteit te tonen in communicatieve situaties met ouders, zijn drie aspecten onderscheiden. Cognitieve flexibiliteit in het domein communicatie met ouders bestaat uit: (a) de onderbouwing van professioneel handelen in realistische situaties met behulp van een conceptuele structuur, waarbij (b) verschillende perspectieven (van betrokkenen) en (c) situatiespecifieke factoren worden betrokken.

De relatie tussen conceptuele kennis en professioneel handelen wordt gezocht in de beredenering van het handelen. Specifiek voor het domein communicatie is het tweede aspect: Het afwegen van de belangen en perspectieven van verschillende 
betrokkenen in een communicatieve situatie is essentieel voor een goed begrip van de communicatieve situatie en voor het bepalen van een adequate handelingsstrategie.

\subsection{Curriculumontwerp}

\subsubsection{Curriculumontwerp als geheel}

Het curriculumontwerp is erop gericht een leerproces te faciliteren waarin conceptuele kennis en (in complexiteit toenemende) praktijksituaties aan elkaar worden verbonden. De inzet van videocases en een concept map vormen de centrale elementen in het curriculumontwerp, waarbij de videocases functioneren als representatie van de beroepspraktijk en de concept map functioneert als representatie van een conceptuele structuur.

In vier opeenvolgende opleidingsfasen wordt steeds gebruik gemaakt van dezelfde conceptuele structuur om de kans te optimaliseren dat de concepten verankerd raken in het geheugen van de student. Per opleidingsfase is een onderwijsarrangement ontwikkeld dat passend is bij de specifieke kenmerken van die opleidingsfase. Figuur 3.1 toont schematisch de opbouw van het curriculumontwerp.

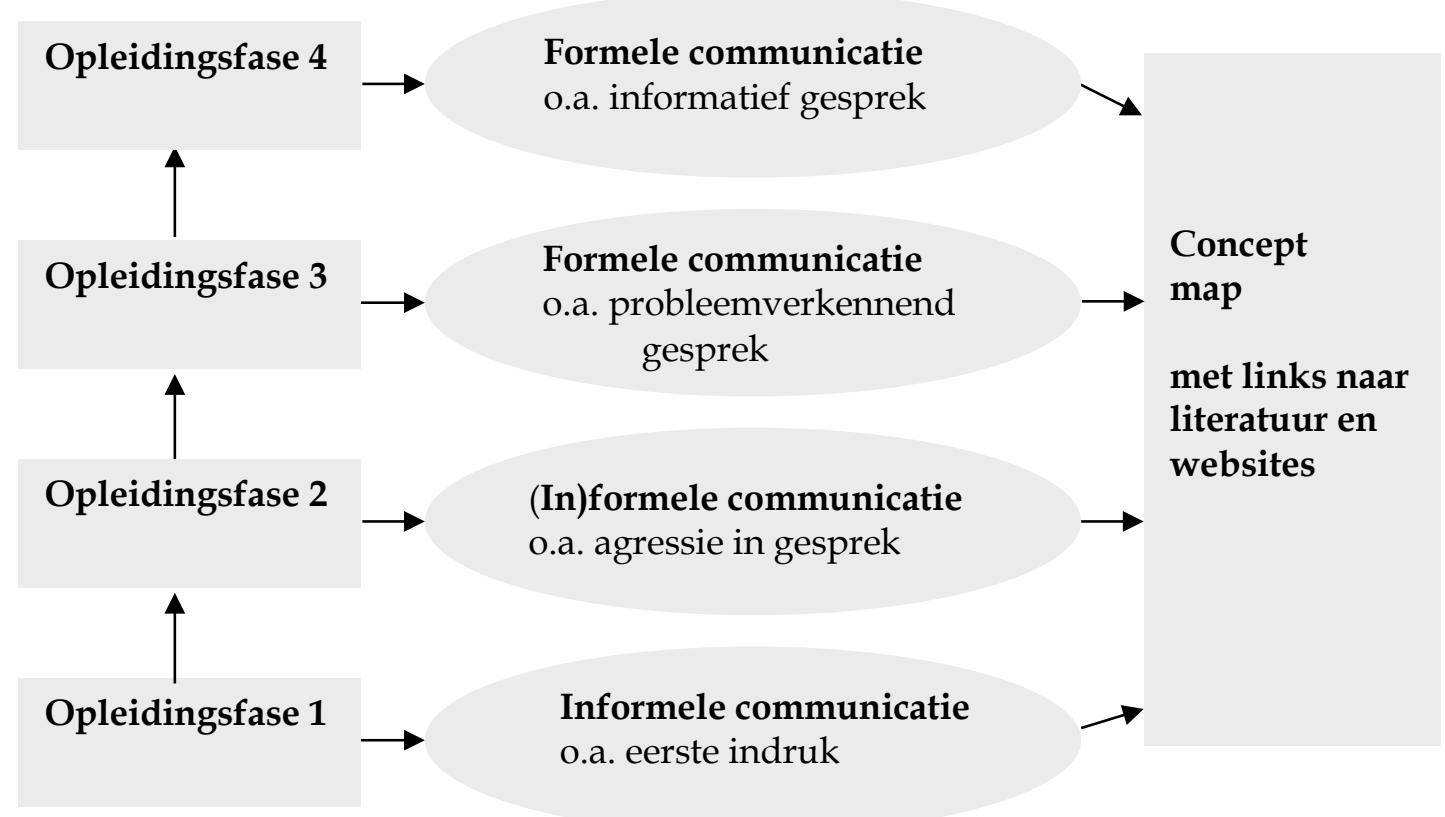

Figuur 3.1 Schematische weergave van curriculumontwerp 


\section{Toenemende complexiteit}

Het curriculumontwerp voorziet in leertaken om leerdoelen te bereiken op zowel het gebied van analyse en interpretatie van communicatieve situaties als op het gebied van professioneel handelen. Een steeds hoger niveau wordt op beide terreinen van de student vereist. Hoewel wordt uitgegaan van authentieke situaties en taken is een opbouw in complexiteit nodig om de overgang van novice naar expert te ondersteunen, waarbij aandacht is voor het oefenen in een veilige setting (Kim \& Hannafin, 2008a). De toenemende complexiteit van het curriculum ligt niet in een steeds hoger niveau van abstractie, maar is te vinden in een toenemende complexiteit van de communicatieve situaties. Die wordt bepaald door vier aspecten:

1. Soort gesprek. Het professioneel handelen in complexere cases vergt de integratie van communicatieve vaardigheden en kennis;

2. Perspectieven. De mate van rolwisseling die wordt gevraagd van de student neemt toe, dat wil zeggen dat het perspectief gaandeweg verlegd wordt van stagiaire naar leerkracht. Afstand nemen van de rol van stagiaire en identificatie met de rol van ervaren leerkracht is lastig en verhoogt de complexiteit. Het innemen van de perspectieven van ouder en school ligt weer een stap verder;

3. Conceptuele kennis. Voor het doorgronden van complexere cases is het noodzakelijk om meer kennis, en kennis uit verschillende domeinen te combineren (communicatie, pedagogiek, psychologie, speciale onderwijsbehoeften);

4. Handelingscontext. De context waarin professioneel handelen getoond wordt, verandert van semi-authentiek (rollenspel) naar authentiek (beroepspraktijk). Het oefenen in een veilige omgeving gaat vooraf aan het uitvoeren van een taak in de authentieke omgeving met de bijbehorende verantwoordelijkheid en complexiteit. In de laatste context moet de student rekening houden met situatiespecifieke factoren.

Op deze wijze kent het curriculumontwerp een opbouw in leerdoelen die in lijn is met de operationalisering van cognitieve flexibiliteit. In onderwijsarrangement 1 ligt het accent op het gebruik van de conceptuele structuur, in onderwijsarrangement 2 en 3 wordt het innemen van diverse perspectieven daaraan toegevoegd en in onderwijsarrangement 4 wordt het betrekken van situatiespecifieke factoren aan het geheel toegevoegd.

De selectie van de videocases en de opbouw van de videocases in de vier onderwijsarrangementen zijn voornamelijk bepaald door een opleidingsdidactisch perspectief, vanwege de randvoorwaarde dat het ontwerp moet aansluiten bij de kenmerken van de opleidingsfasen van het bestaande curriculum van de lerarenopleiding. Dit betekent bijvoorbeeld dat in opleidingsfase 3 een videocasus is ontwikkeld over interculturele communicatie, omdat in deze fase de sociaalmaatschappelijke context van de school centraal staat in de opleiding. In Tabel $3.1 \mathrm{wordt}$ weergegeven hoe de toenemende complexiteit in het curriculumontwerp vorm krijgt. 
Tabel 3.1 Toenemende complexiteit in curriculumontwerp

\begin{tabular}{|c|c|c|c|c|}
\hline Ontwerp & $\begin{array}{l}\text { Videocases: soort } \\
\text { gesprek }\end{array}$ & Perspectief & $\begin{array}{l}\text { Kennis- } \\
\text { domeinen }\end{array}$ & $\begin{array}{l}\text { Handelings- } \\
\text { context }\end{array}$ \\
\hline 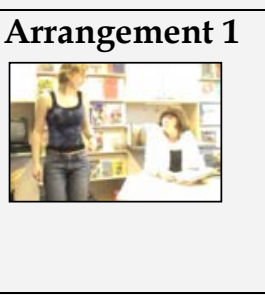 & $\begin{array}{l}\text { Informele } \\
\text { communicatie } \\
\text { Welk effect hebben } \\
\text { mijn uiterlijk en } \\
\text { gedrag op ouders en } \\
\text { collegae? }\end{array}$ & Student & Communicatie & - \\
\hline Arrangement 2 & $\begin{array}{l}\text { Informele en formele } \\
\text { communicatie } \\
\text { Welke ouders betrek } \\
\text { ik bij onderwijs? } \\
\text { Hoe reageer ik op } \\
\text { agressieve ouders? } \\
\text { Hoe ga ik om met } \\
\text { een onverwacht } \\
\text { gesprek? }\end{array}$ & $\begin{array}{l}\text { Student } \\
\text { Leerkracht } \\
\text { Ouder } \\
\text { School }\end{array}$ & $\begin{array}{l}\text { Communicatie } \\
\text { Pedagogiek } \\
\text { Psychologie }\end{array}$ & $\begin{array}{l}\text { Semi-authentiek } \\
\text { met peers }\end{array}$ \\
\hline & $\begin{array}{l}\text { Formele communicatie } \\
\text { Hoe voer ik een } \\
\text { probleemverkennend } \\
\text { intercultureel } \\
\text { gesprek? } \\
\text { Hoe voer ik een } \\
\text { informatief gesprek } \\
\text { over een gevoelig } \\
\text { onderwerp? }\end{array}$ & $\begin{array}{l}\text { Leerkracht } \\
\text { Ouder } \\
\text { School }\end{array}$ & $\begin{array}{l}\text { Communicatie } \\
\text { Pedagogiek } \\
\text { Psychologie } \\
\text { Speciale } \\
\text { onderwijs- } \\
\text { behoeften }\end{array}$ & $\begin{array}{l}\text { Semi-authentiek } \\
\text { met peers }\end{array}$ \\
\hline $\begin{array}{l}\text { Arrangement } 4^{4} \\
\end{array}$ & $\begin{array}{l}\text { Formele communicatie } \\
\text { Hoe voer ik een } \\
\text { tienminutengesprek? }\end{array}$ & $\begin{array}{l}\text { Leerkracht } \\
\text { Ouder } \\
\text { School }\end{array}$ & $\begin{array}{l}\text { Communicatie } \\
\text { Pedagogiek } \\
\text { Afhankelijk van } \\
\text { context }\end{array}$ & $\begin{array}{l}\text { Semi-authentiek } \\
\text { met acteurs } \\
\quad+ \\
\text { Authentiek } \\
\text { met ouders }\end{array}$ \\
\hline
\end{tabular}

\subsubsection{Ontwerprichtlijn 1: gebruik maken van realistische situaties}

De eerste ontwerprichtlijn stelt het gebruik maken van realistische situaties centraal. Het centraal stellen van realistische situaties uit de beroepspraktijk is goed verenigbaar met de randvoorwaarde van competentiegericht onderwijs. In deze visie op onderwijs wordt het leerproces namelijk vormgegeven rondom de authentieke beroepspraktijk en de taken die daaruit voortvloeien.

Studenten van een lerarenopleiding kunnen op verscheidene manieren in aanraking worden gebracht met realistische situaties op het gebied van communiceren met ouders. Het meest realistisch is het gebruik maken van authentieke situaties in de

4 Dit laatste arrangement is tot stand gekomen op basis van de formatieve evaluatie van het aanvankelijke ontwerp. 
basisschool tijdens de stages. Uitsluitend gebruik maken van deze vorm van realisme is echter haalbaar noch effectief: niet alle studenten worden voldoende in de gelegenheid gesteld met ouders in contact te komen en de communicatieve situaties die ze tegenkomen zijn onvoorspelbaar. Realistische situaties kunnen ook worden gerepresenteerd in de vorm van geschreven cases, audioverhalen, videocases en multimediacases. In dit onderzoek zijn videocases ontworpen die functioneren als representatie van de beroepspraktijk, zogenaamde designed videocases (Schwarz \& Hartmann, 2007). Gebruik maken van videocases biedt enkele voordelen: videobeelden kunnen herhaald worden bekeken en reflectie op de situatie is mogelijk, omdat er niet, zoals in de praktijk, onmiddellijk hoeft te worden gehandeld (Van Es \& Sherin, 2010; Zhang et al., 2011). Aan de hand van videobeelden kunnen reflectieve en analytische vaardigheden worden ontwikkeld, waarbij geleerd wordt redeneringen te staven met bewijsvoering uit de videobeelden en te focussen op inhoudelijke issues (Borko et al., 2008; Rosaen et al., 2008; Stockero, 2008). Het voordeel van het gebruik van videocases is tegelijkertijd een nadeel: videocases bieden de mogelijkheid tot reflectie en analyse, omdat er niet hoeft te worden gehandeld. In die zin vervangt de videocasus dus niet alle aspecten van de authentieke situatie.

De ontworpen videocases bevatten realistische en herkenbare communicatieve situaties tussen ouders en leerkrachten uit de beroepspraktijk van het basisonderwijs. De case library beslaat een breed palet aan communicatieve situaties tussen ouders en leerkrachten, lopend van een informeel praatje op het schoolplein tot een formeel gesprek over de cognitieve ontwikkeling van een kind. De videocases laten zich karakteriseren als dilemma-focused en functioneren als trigger. De triggers brengen een lastige situatie uit de onderwijspraktijk in beeld. Deze lastige situatie wordt uitgebeeld op een realistische, maar niet per se ideale manier. In sommige gevallen wordt de meerduidigheid van de situatie benadrukt doordat verschillende oplossingen of handelingsalternatieven worden getoond. Voor een ill-structured domein als de communicatiekunde zijn dilemma-focused videocases geschikt, omdat daarmee de complexiteit van communicatieve situaties en de verscheidene afwegingen die kunnen leiden tot verschillende passende oplossingen expliciet gemaakt kunnen worden. Beoogd wordt met de videocases een leerproces op gang te brengen waarin discussie, analyse, interpretatie en kritische reflectie plaatsvinden (cf. tertiair gebruik van video, Wallace, 2002).

\subsubsection{Ontwerprichtlijn 2: centrale concepten in diverse contexten bestuderen}

De tweede ontwerpeis betreft het bestuderen van de centrale concepten van een domein in diverse contexten. Idealiter bevat het curriculumontwerp zoveel mogelijk te bestuderen videocases van communicatieve situaties (contexten), opdat studenten de centrale concepten vaak kunnen toepassen om zo een goed begrip te ontwikkelen van de reikwijdte van de concepten. Een randvoorwaarde voor het ontwerp is echter 
een beperkt aantal beschikbare studiepunten en uren contacttijd met docenten. Hierdoor wordt het aantal te bestuderen videocases beperkt.

In de opzet van het curriculum als geheel en van ieder onderwijsarrangement op zich, is gepoogd, met inachtneming van de randvoorwaarden die het bestaande opleidingscurriculum stelt, toch zoveel mogelijk contexten te creëren waarin het conceptuele kader kan worden gehanteerd. Op de keuzes die gemaakt zijn voor het geheel en per onderwijsarrangement, wordt nu nader ingegaan.

\section{Uitgangspunt voor gehele curriculum}

Het ontworpen curriculum bestaat uit vier onderwijsarrangementen die in elkaars verlengde liggen. Deze opzet als geheel - met opeenvolgende onderwijsarrangementen (gespreid over vier jaar) - biedt de gelegenheid om centrale concepten herhaaldelijk toe te passen op verscheidene videocases, zodat deze betekenisvol kunnen worden in het denken en professioneel handelen van de student. Naast de herhaling van centrale concepten, worden per videocasus ook concepten geleerd die specifiek van toepassing zijn op die bepaalde casus. Bijlage A geeft een overzicht van de concepten die aan iedere casus zijn verbonden.

In de opzet van het curriculum- en instructieontwerp zijn 'analyseren' en 'professioneel handelen' steeds nauw met elkaar verbonden en er is dan ook sprake van (a) contexten voor analyse en (b) contexten voor professioneel handelen, inclusief analyse/verantwoording. De videocases bieden in de eerste plaats de contexten voor analyse. Daarbij kent het curriculumontwerp een opbouw in de context waarin het eigen professioneel handelen wordt verbonden aan conceptuele kennis. Studenten produceren namelijk zelf (semi-)authentieke videobeelden waarin zij hun eigen communicatieve vaardigheden tonen en hun interpretatie van de communicatieve situatie verantwoorden met behulp van concepten. In ieder onderwijsarrangement zijn, ingegeven door randvoorwaarden en opleidingsdidactische motivaties, specifieke keuzes gemaakt voor het creëren van zoveel mogelijk passende analyse- en handelingscontexten die hieronder worden toegelicht.

\section{Uitwerking in onderwijsarrangementen}

In opleidingsfase 1 wordt een videocasus geanalyseerd en geïnterpreteerd met behulp van enkele centrale concepten. Een tweede context waarin de conceptuele structuur wordt toegepast is de authentieke beroepspraktijk: studenten voeren een analysetaak uit in de basisschool. De issues die centraal staan in beide contexten passen bij de transitie van student naar stagiaire. Vanwege de kenmerken van deze opleidingsfase (waarin studenten geen gesprekken met ouders voeren) worden geen videobeelden geproduceerd, maar wordt een tweede analysetaak uitgevoerd. In deze fase is nog geen sprake van advanced learning, maar worden studenten ingeleid in het vakgebied en maken ze kennis met het begrippenkader.

In opleidingsfase 2 worden drie verschillende videocases geanalyseerd en geïnterpreteerd; het professioneel handelen wordt getoond in een semi-authentieke context door middel van een rollenspel met peers. De eigen videobeelden worden voorzien van een verantwoording waarin het professioneel handelen wordt 
beredeneerd met behulp van concepten. Om meer contexten te creëren voor het toepassen van centrale concepten, is bij dit onderwijsarrangement een toetsvorm ingezet waarbij studenten de gezamenlijk geproduceerde videobeelden aan elkaar presenteren. In de presentatie maken studenten elkaar deelgenoot van hun analyse, interpretatie en oplossingsalternatief en hanteren zij de concepten zo goed mogelijk in een professioneel discours. Het delen van de videobeelden met elkaar levert een extra gelegenheid om de concepten te hanteren en eventueel bij te stellen.

In opleidingsfase 3 worden twee complexe videocases geanalyseerd en geïnterpreteerd. In deze fase is communicatie geen zelfstandige onderwijseenheid, maar wordt binnen het onderwijsarrangement samengewerkt met drie andere vakgebieden in thematisch samenhangend onderwijs. De samenwerking met andere vakgebieden is een randvoorwaarde en levert voor- en nadelen op voor het curriculumontwerp. Passend binnen de ontwerpeisen is dat de videocases en het onderwerp communicatie in een breder perspectief wordt geplaatst en vanuit meer invalshoeken wordt benaderd; de analyse van de videocases vergt integratie van kennis uit diverse domeinen, wat een wezenlijke aspect van cognitieve flexibiliteit vormt. Een nadeel is dat de uiteenlopende doelstellingen van de vakgebieden lastig zijn te realiseren. Net als in opleidingsfase 2 wordt het professioneel handelen in een semi-authentieke context met peers getoond - de zelfgeproduceerde videobeelden worden voorzien van een verantwoording waarin het professioneel handelen wordt beredeneerd met behulp van de conceptuele structuur. Ook worden presentaties van de eigen videobeelden ingezet om een extra gelegenheid te creëren voor het toepassen en bijstellen van centrale concepten.

Onderwijsarrangement 4 heeft een iets ander karakter dan de voorgaande. Analyse van een videocasus vindt plaats, maar het accent ligt op authentieke contexten, waarin het eigen professioneel handelen verbonden wordt aan de conceptuele structuur. Dat gebeurt eerst in een training met een acteur en daarna in de basisschool door het voeren van een gesprek met ouders.

Tijdens de training worden diverse contexten aangedragen door de studenten en worden als moeilijk ervaren situaties uitgespeeld en geoefend met acteurs. Mondelinge analyse van de situaties en feedback geven op de getoonde communicatieve vaardigheden vinden plaats met behulp van de eerder geleerde centrale concepten. Deze werkwijze biedt de kans de conceptuele structuur op een directe manier te verbinden aan het professioneel handelen van studenten in contexten die voor hen betekenisvol zijn. De werkwijze sluit nauw aan bij de kenmerken van de afstudeerfase en de concerns van de studenten in deze fase die in de stage daadwerkelijk gesprekken met ouders voeren.

Vanwege de kenmerken van deze opleidingsfase is ook het eindproduct enigszins afwijkend van die in de vorige onderwijsarrangementen. In deze fase moet iedere student individueel aantonen een startbekwaam niveau te behalen en daarom produceert iedere student individuele videobeelden met een verantwoording. Professioneel handelen wordt getoond met videobeelden van een gesprek met ouders dat de student in zijn stageschool voert. Daaraan wordt een schriftelijke voorbereiding, analyse en reflectie toegevoegd waarin het professioneel handlen 
wordt beredeneerd met gebruikmaking van de conceptuele structuur. De mate van complexiteit wordt voornamelijk bepaald door de authentieke context waarin het gesprek plaatsvindt en de daarmee gepaard gaande situatiespecifieke factoren . Mogelijkerwijs is de communicatieve situatie zelf minder complex dan de geoefende situaties in de vorige opleidingsfasen. De authentieke videobeelden worden gedeeld met een kleine groep medestudenten die feedback geeft; dit levert een context op waarin de concepten nogmaals gehanteerd en bijgesteld kunnen worden.

In Tabel 3.2 wordt een overzicht gegeven van de verscheidene contexten waarin de conceptuele structuur wordt toegepast per onderwijsarrangement.

Tabel 3.2 Contexten voor toepassing van conceptuele structuur

\begin{tabular}{l|l|l} 
& Contexten analyse & Contexten handelen \\
\hline Arrangement 1 & $\begin{array}{l}\text { Videocasus } \\
\text { Basisschool }\end{array}$ & - \\
\hline Arrangement 2 & $\begin{array}{l}\text { Videocases } \\
\text { Presentaties met videobeelden peers }\end{array}$ & $\begin{array}{l}\text { Rollenspel met peers } \\
\text { (incl. video-opname) }\end{array}$ \\
\hline Arrangement 3 & $\begin{array}{l}\text { Videocases } \\
\text { Presentaties met videobeelden peers }\end{array}$ & $\begin{array}{l}\text { Rollenspel met peers } \\
\text { (incl. video-opname) }\end{array}$ \\
\hline Arrangement 4 & $\begin{array}{l}\text { Videocasus } \\
\text { Bespreking met peers in kleine groep } \\
\text { van videobeelden basisschool }\end{array}$ & $\begin{array}{l}\text { Gesprek met ouders in basisschool } \\
\text { (incl. video-opname) }\end{array}$
\end{tabular}

\subsubsection{Ontwerprichtlijn 3: cases interpreteren met behulp van concepten uit verscheidene domeinen}

De derde ontwerprichtlijn stelt het gebruik van concepten uit verscheidene domeinen centraal, aangezien voor het interpreteren en oplossen van complexe realistische situaties vrijwel altijd kennis uit meer domeinen moet worden gecombineerd (Derry \& STEP Team, 2003). Voor de analyse van de videocases wordt in de vier onderwijsarrangementen gebruik gemaakt van een conceptuele structuur die concepten bevat uit diverse inhoudelijke domeinen. Deze concepten zijn ondergebracht in een concept map. Daaronder wordt verstaan: een door experts samengestelde, samenhangende structuur van essentiële begrippen uit een kennisdomein die worden omschreven en toegelicht (Novak \& Canas, 2006). De belangrijkste functies van een concept map zijn (a) het bieden van een overzicht van de belangrijkste concepten van een kennisdomein en (b) het bieden van inzicht in de samenhang van die concepten.

Met het oog op het leerproces wordt verwacht dat studenten baat hebben bij een overzichtelijke presentatie van de centrale concepten; de concept map is een cognitief gereedschap dat eraan bijdraagt dat de concepten systematisch georganiseerd in het geheugen kunnen worden opgeslagen. De analyse van de videocases leidt immers tot een indexering van de cases; het gebruik van een conceptuele structuur helpt bij het tot stand komen van een abstractere vorm van indexering, waardoor het gemakkelijker wordt cases te categoriseren, in het geheugen op te slaan en uit het 
geheugen op te roepen ter vergelijking met een nieuwe casus. Overigens wordt niet verwacht dat studenten, beginnend of gevorderd, een kennisstructuur van een expert of een wetenschappelijke kennisstructuur kant-en-klaar in zich opnemen. Leren wordt in dit onderzoek beschouwd als een constructief en dynamisch proces dat wordt beïnvloed door voorkennis, ervaring, motivatie en persoonlijke concerns (Kessels \& Korthagen, 1996; Korthagen \& Kessels, 1999). Echter, het opbouwen van een persoonlijke kennisstructuur kan aan snelheid en efficiency winnen wanneer dit proces wordt ondersteund door een effectieve instructie en leeromgeving (Spiro et al., 2003, 2007) en een systematische kennisstructuur.

De concept map is bedoeld als cognitief gereedschap en maakt deel uit van de digitale leeromgeving, net zoals de videocases. In de instructie wordt steeds gestreefd naar het leggen van een verbinding tussen deze concepten en de realistische situatie die wordt geanalyseerd; het gaat om het zodanig toepassen van de concepten op een communicatieve situatie dat (a) de situatie verhelderd en begrepen wordt en (b) op een abstracter niveau over de situatie kan worden gesproken en gedacht. De concepten maken deel uit van een professionele kennisbasis en zijn bedoeld om professioneel handelen mee te beredeneren. Ze zijn daarom verschillend van aard en hebben betrekking op zowel declaratieve als procedurele en conditionele kennis (zie hoofdstuk 2). Met de term conceptuele kennis wordt in dit onderzoek verwezen naar de verzameling van deze verschillende typen concepten.

De concept map is ontworpen als een digitaal gereedschap. Een voordeel van de digitale vorm is dat dit de mogelijkheid biedt tot onmiddellijke beschikbaarheid van informatie, toevoeging van verwijzingen naar relevante bronnen en uitbreiding met andere relevante kennisdomeinen. In concreto is een beperkt aantal concepten uit de communicatiekunde, pedagogiek en psychologie opgenomen in de concept map. De concept map opent als introductie met een pagina waarop het gehanteerde communicatiemodel, staat vermeld. Dit communicatiemodel is een concept dat steeds wordt herhaald en bestaat zelf uit diverse concepten. In Figuur 3.2 wordt de openingspagina van de concept map met het communicatiemodel weergegeven. 


\section{Communiceren met ouders}

Je vindt hier informatie over communicatie van leerkrachten met ouders.

Het onderwijs is een bijzondere context: in de communicatie gaat het immers altijd om het belang van een ander, het kind. Een plezierige relatie tussen leerkracht en ouders is voor alle partijen een kostbaar goed.

Bruikbare begrippen uit de communicatiekunde en pedagogiek worden verbonden aan situaties tussen leerkrachten en ouders. Je maakt je een begrippenkader eigen. Daarmee kun je analyseren wat er eigenlijk gebeurt in communicatie tussen mensen. Inzicht in factoren die communicatie beïnvloeden, helpt bij het verbeteren van je communicatieve vaardigheden. En dat leidt tot ... professioneel en effectief communiceren.

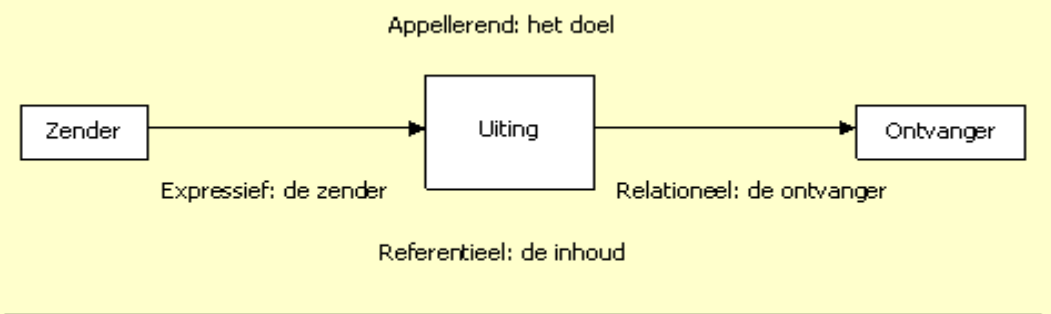

Basismodel van communicatie

Meer info over communicatiemodel:

referentiele, expressieve, relationele boodschap en communicatieve doelen

Figuur 3.2 Openingspagina van concept map

De pagina toont het gehanteerde basismodel van communicatie (uit Steehouder, M. et al., (1999). Leren communiceren. Handboek voor mondelinge en schriftelijke communicatie. 4e geheel herziene druk. Groningen: Wolters-Noordhoff).

De hoofdstructuur van de concept map bestaat uit 'Communicatiemodel, Mondelinge Communicatie, Schriftelijke communicatie en Onderwijscontext. (Dit onderzoek laat schriftelijke communicatie buiten beschouwing). In de categorie Mondelinge Communicatie zijn concepten opgenomen zoals 'soorten gesprekken, opbouw van gesprekken, gespreksvaardigheden'. In de categorie Onderwijscontext zijn concepten opgenomen die typerend zijn voor communicatie tussen leerkrachten en ouders in het onderwijs. Hieronder vallen enkele concepten uit het pedagogische domein zoals loyaliteit en dynamische driehoek, maar ook de algemene begrippen deskundigheid en verantwoordelijkheid van de leerkracht zijn hier opgenomen, waarbij onder andere wordt verwezen naar de (juridische) informatieplicht van een school. In Figuur 3.3 is de hoofdstructuur van de concept map te zien met een aantal concepten dat hoort bij gesprekken. 


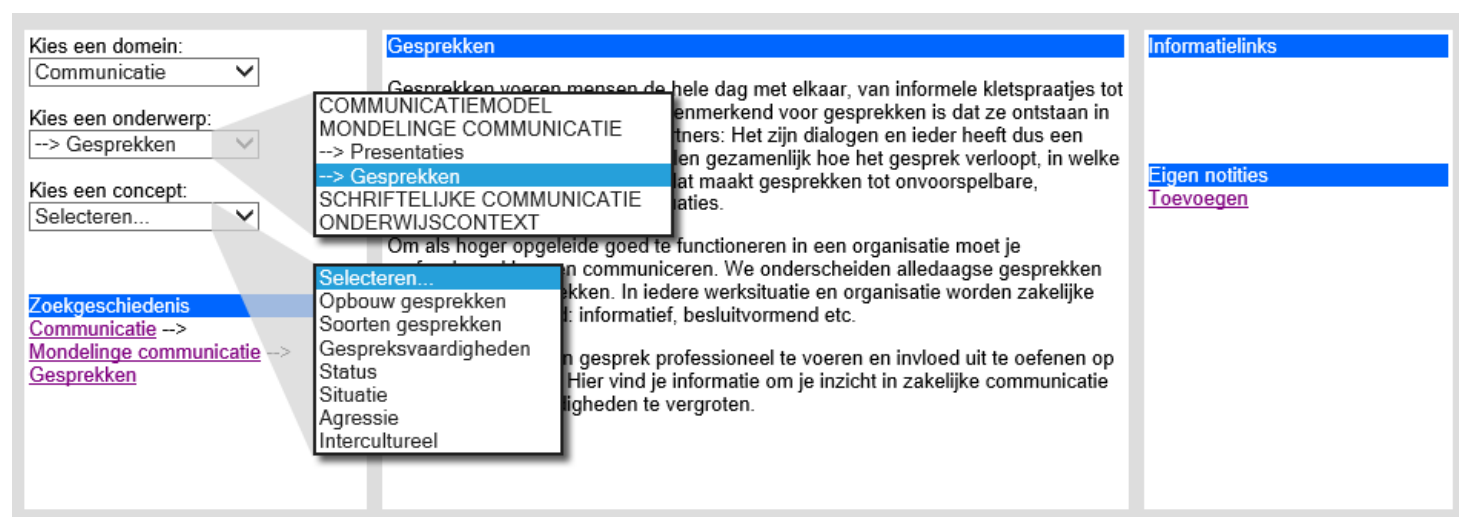

Figuur 3.3 Hoofdstructuur concept map

De concept map heeft ook als functie inzicht te bieden in de samenhang van concepten. Daartoe zijn de relaties tussen de concepten gedefinieerd. Per concept is opgenomen:

- de omschrijving van het concept (met voorbeeld uit onderwijs)

- de verbinding van het concept met andere concepten

- de verbinding met informatielinks: geselecteerde websites, google, wikipedia, literatuur

- eigen notities bij het concept

- eigen zoekgeschiedenis.

In Figuur 3.4 is te zien hoe het concept gespreksvaardigheden is opgenomen in de concept map; in de rechterkolom worden de relaties met andere concepten genoemd.

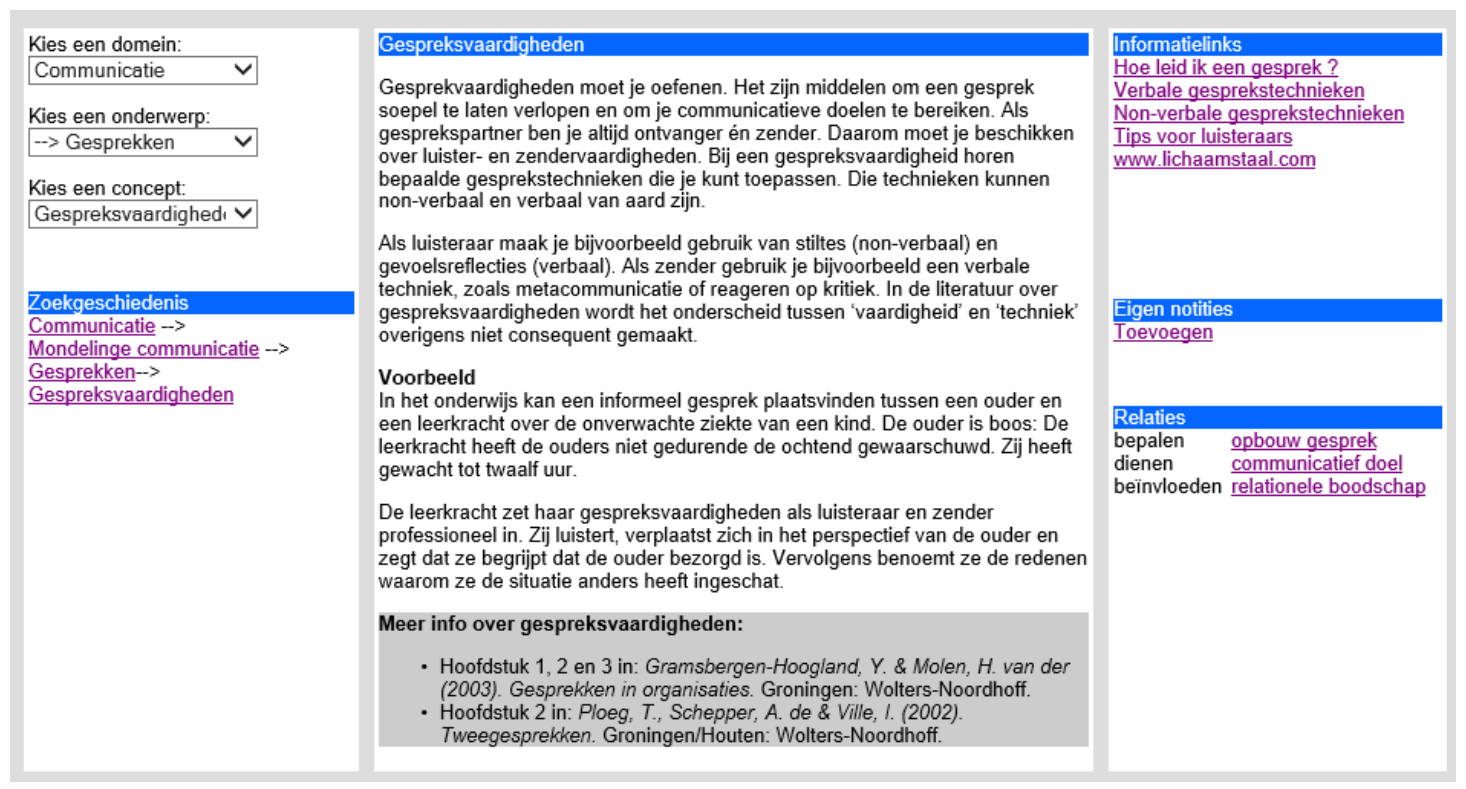

Figuur 3.4 Weergave van het concept 'gespreksvaardigheden', inclusief relaties met andere concepten. 
In het ontworpen curriculum is het voorwaardelijk dat de concept map in iedere opleidingsfase toegankelijk is. Concepten worden herhaaldelijk toegepast, andere concepten zijn specifiek voor een bepaalde casus. De herhaling maakt het mogelijk dat basisconcepten - en de daarmee gepaard gaande analytische werkwijze verankerd raken in de persoonlijke kennisstructuur van de student. Studenten gebruiken en hergebruiken de concept map als kennisbasis in ieder onderwijsarrangement om daarmee hun persoonlijke kennisstructuur op te bouwen, uit te breiden en te verfijnen (Spiro et al., 1992).

Bijlage A bevat een overzicht van alle videocases in het curriculum en de concepten die aan iedere videocasus zijn verbonden.

De concept map heeft diverse stadia van ontwikkeling gekend en is in een formatief proces met enkele prototypes tot stand gekomen. De eerste outline van een digitale concept map werd in 2006 gemaakt waarbij ict-deskundigen en docenten van de opleiding voor primair onderwijs waren betrokken. Een belangrijke bevinding was dat opleidingsdocenten niet vanzelfsprekend vakinhoudelijke en opleidingsdidactische aspecten van hun vakgebied loskoppelen. Het formuleren van concepten die essentieel zijn voor het vak dat zij doceren, bleek zeer lastig en te leiden tot uiteenlopende resultaten (Leeuw, Kemmeren, \& van den Berg, 2006).

Het eerste prototype van de concept map voor communicatie is ontworpen door een team van twee inhoudsdeskundigen, twee ict-specialisten en een onderwijskundige. De concept map bevatte begrippen en hun onderlinge relaties, uit de communicatiekunde en onderwijskunde-pedagogiek. Tevens waren verwijzingen opgenomen naar relevante, schriftelijke bronnen. De aanname was dat verwijzingen naar schriftelijke bronnen zouden werken, vanwege de ervaring in het Surfonderzoeksproject Colevi met deeltijdstudenten (van den Berg et al., 2005), waarbij de deeltijdstudenten zeer gemotiveerd en zoekend naar theoretische diepgang waren. Voor reguliere voltijdstudenten bleken de verwijzingen naar schriftelijke bronnen niet goed te werken. Het hybride karakter van de concept map, enerzijds digitaal, anderzijds verwijzend naar schriftelijke bronnen, functioneerde niet goed, want voltijdsstudenten raadpleegden de schriftelijke bronnen niet of onvoldoende. $\mathrm{Na}$ een formatieve evaluatie onder studenten en docenten heeft verdere ontwikkeling van de concept map plaatsgevonden in de richting van een compleet digitaal documentair informatiesysteem, waarbij links naar relevante websites zijn opgenomen, zodat alle informatie direct beschikbaar was.

Technologisch bleek het zeer weerbarstig om het principiële uitgangspunt - het weergeven van een conceptuele structuur én van de onderlinge relaties tussen de begrippen - te programmeren. Dit is wel in basale vorm gerealiseerd, maar een aantrekkelijk vormgegeven applicatie vraagt teveel investering in technologie. Volgens de cognitieve flexibiliteitstheorie behoort een instructie studenten te ondersteunen bij het leren analyseren en interpreteren van cases waarbij concepten uit diverse kennisdomeinen flexibel gecombineerd en toegepast worden. Idealiter worden hierbij hypermedia-omgevingen ontworpen die voorzien in de 
mogelijkheden voor niet-lineaire leerstrategieën, metaforisch omschreven als 'crisscrossing domains of practice and conceptual domains, resulting in cognitive flexibility' (Derry et al., 2006; Spiro et al., 1992). Het ontwikkelen van een zorgvuldig ontworpen hypermedia-omgeving met digitale tools waarin niet-lineaire leerstrategieën worden gefaciliteerd, valt buiten het bestek van dit proefschrift.

\subsection{Instructie-ontwerp}

Het curriculum- en instructieontwerp in zijn geheel is erop gericht een verbinding te bewerkstelligen tussen conceptuele kennis en professioneel handelen. In deze paragraaf wordt eerst het instructieontwerp beschreven aan de hand van één ontwerprichtlijn. De voorgaande drie ontwerprichtlijnen die zich bevinden op een algemener curriculumniveau, worden in het instructieontwerp gepreciseerd en gespecificeerd. Het instructieontwerp laat zien hoe het curriculumontwerp geconcretiseerd wordt in didactische keuzes (3.3.1). Daarna wordt op een concreet niveau beschreven hoe de onderwijsarrangementen en de leeromgeving zijn vormgegeven (3.3.2).

\subsubsection{Ontwerprichtlijn 4: een beperkt aantal rijke videocases diepgaand bestuderen}

De vierde ontwerprichtlijn wijst op het belang van het diepgaand bestuderen van videocases: dit draagt bij aan een dieper begrip van zowel de gegeven situatie als de gehanteerde concepten. In het instructieontwerp zijn verscheidene middelen gecombineerd die in samenhang een diepgaande bestudering van de videocases bewerkstelligen. Centraal in het instructieontwerp staat de leertaak voor studenten waaraan een didactisch model ten grondslag ligt. In het didactische model zijn keuzes gemaakt met betrekking tot de soort leeractiviteiten en de werkwijze. In deze paragraaf worden de gemaakte keuzes binnen het didactisch model en binnen het gehele instructieontwerp verantwoord met behulp van inzichten omtrent case-based learning, cognitieve flexibiliteit en case-based reasoning.

\section{Kenmerken van didactisch model en leertaken}

In het instructieontwerp zijn leertaken ontwikkeld om studenten te sturen bij het diepgaand bestuderen van de videocases ${ }^{5}$. De leertaken bestaan uit twee kerntaken die beide ten doel hebben een verbinding tussen de conceptuele structuur en het professioneel handelen te leggen:

1. analyse en interpretatie van de videocasus met behulp van concepten

2. productie van eigen videobeelden met toelichting.

5 De kwaliteit van de leertaken en de beoordeelbaarheid van de eindproducten zijn getoetst. Gebleken is dat aan belangrijke voorwaarden voor een valide beoordeling van videodossiers wordt voldaan; verbetering van de contextinformatie is mogelijk (Staman, 2009). 
Aan de leertaken ligt een didactisch model ten grondslag dat in een eerder uitgevoerd SURF-onderzoeksproject is getest op zijn bruikbaarheid en kwaliteit (Berg, Bakx, Thijs, \& Kemmeren, 2005). Het model bestond aanvankelijk uit vier fasen en is in deze studie uitgebreid met een vijfde fase. Alvorens we verder ingaan op het didactisch model en de leertaak, wordt in Tabel 3.3 kort de opbouw van de leertaak en de samenhang van leerprocessen en leeractiviteiten in het didactisch model weergegeven.

Tabel 3.3 Leerprocessen en leeractiviteiten in het didactisch model

\begin{tabular}{l|l|l} 
Leertaak & Leerproces & Leeractiviteit \\
\hline 1. Introductie & $\begin{array}{l}\text { Mentaal beeld opbouwen: } \\
\text { Voorkennis activeren } \\
\text { Confronteren met andere } \\
\text { perspectieven }\end{array}$ & $\begin{array}{l}\text { Studenten bekijken de videocasus } \\
\text { individueel; } \\
\text { Studenten bediscussiëren de } \\
\text { videocasus. }\end{array}$ \\
\hline $\begin{array}{l}\text { 2. Conceptuele } \\
\text { verdieping }\end{array}$ & $\begin{array}{l}\text { Analyseren: } \\
\text { (individueel) }\end{array}$ & $\begin{array}{l}\text { Studenten analyseren de videocasus } \\
\text { met behulp van (deel) conceptuele } \\
\text { structuur. }\end{array}$ \\
\hline 3. Integratie & $\begin{array}{l}\text { Integreren: } \\
\text { Samenvoegen met andere } \\
\text { concepten; } \\
\text { Samenvoegen van meer } \\
\text { perspectieven en persoonlijke } \\
\text { interpretaties; }\end{array}$ & $\begin{array}{l}\text { Studenten wisselen hun resultaten uit, } \\
\text { voegen die samen en herschrijven } \\
\text { casus gezamenlijk tot 'ideale' casus. }\end{array}$ \\
\hline 4. Toepassing & $\begin{array}{l}\text { Toepassen: } \\
\text { Uitvoeren en toepassen van } \\
\text { het geleerde }\end{array}$ & $\begin{array}{l}\text { Studenten maken gezamenlijk } \\
\text { videobeelden, inclusief toelichting } \\
\text { waarin conceptuele structuur wordt } \\
\text { toegepast. }\end{array}$ \\
\hline 5. Explicitering & $\begin{array}{l}\text { Expliciteren: } \\
\text { Expliciteren en verantwoorden } \\
\text { van interpretatie }\end{array}$ & $\begin{array}{l}\text { Studenten presenteren gezamenlijke } \\
\text { videobeelden met PPP aan peers en } \\
\text { docenten. }\end{array}$ \\
\hline
\end{tabular}

Alle leertaken zijn in principe op dezelfde manier opgebouwd, namelijk volgens het didactisch model rondom twee kerntaken. Vanwege het opleidingsdidactische perspectief zijn binnen ieder onderwijsarrangement specifieke keuzes gemaakt op het gebied van de inhoud en volgorde van de videocases en de precieze vormgeving van het onderwijsarrangement. Met name in onderwijsarrangement één en vier zijn ook aanpassingen gedaan aan de twee geformuleerde kerntaken.

De introductiefase van de leertaak geeft studenten de kans om een mentaal beeld van de gegeven situatie op te bouwen; eerst individueel en daarna in een uitwisseling met medestudenten. Individuele en gezamenlijke werkwijzen leiden tot verscheidene typen commentaar en reflectie (Zhang et al., 2011) en dragen daardoor bij aan het 
opbouwen van een veelzijdig mentaal beeld. De videocasus is in eerste instantie bedoeld om voorkennis, opvattingen en denkprocessen te activeren, eigen ideeën te expliciteren en een confrontatie met alternatieve zienswijzen aan te gaan. Kijkers van videobeelden blijken bovendien meteen te reageren op de videobeelden met emotioneel, ter zake doende en ook niet ter zake doende commentaar (Abell, Bryan, \& Anderson, 1998). Het didactisch model incorporeert dit proces: De introductiefase geeft hiertoe gelegenheid en structureert dit.

$\mathrm{Na}$ een aanvankelijke discussie wordt in de tweede fase van conceptuele verdieping de videocasus schriftelijk geanalyseerd met behulp van de conceptuele structuur, waarbij iedere student een deel van de analyse voor zijn rekening neemt. Bij deze analysetaak wordt gebruik gemaakt van (een deel van) de concept map. In overeenstemming met de cognitieve flexibiliteitstheorie richten de analyseopdrachten de student op het toepassen van concepten, op het betrekken van de specifieke context en op het innemen van verschillende perspectieven om een genuanceerd beeld van de situatie te verkrijgen.

In de derde fase, de integratiefase, worden de aparte delen van de analyse samengevoegd tot een geheel en leidt de coöperatieve leertaak tot een gezamenlijke analyse en interpretatie van de bestudeerde situatie. Persoonlijke interpretaties van de gehanteerde concepten worden in dit uitwisselingsproces tegelijkertijd bijgesteld. Vervolgens bediscussiëren de studenten wat in hun ogen een ideale aanpak van de situatie is; om tot een gezamenlijke oplossing van het probleem te komen en een handelingsalternatief te beschrijven, vindt een proces van afweging, argumentatie en onderhandeling plaats, waarbij ieder individu zijn persoonlijke perspectief inbrengt. De bestudeerde videocasus wordt herschreven tot een ideaal script waarin de verscheidene perspectieven en interpretaties van de studenten worden geïntegreerd.

$\mathrm{Na}$ analyse van de videocasus, wordt in de toepassingsfase een (semi-)authentieke taak uitgevoerd. Omdat het leren van cases kort gezegd is gebaseerd op het idee dat mensen leren van ervaring, is het voor de vormgeving van het onderwijs wezenlijk dat studenten actief ervaringen opdoen (Kolodner, 2006; Kolodner \& Guzdial, 2004; Kim \& Hannafin, 2008a). Dit hands-on uitgangspunt is in de toepassingsfase van het didactisch model geconcretiseerd doordat studenten zelf een gesprek met ouders voeren en videobeelden produceren met semi-authentieke dan wel authentieke beelden. Het ideale script wordt uitgespeeld en opgenomen en de benodigde communicatieve vaardigheden van de leerkracht worden in het rollenspel geoefend. Om videobeelden te maken die gepresenteerd kunnen worden aan medestudenten, wordt de opname bewerkt: studenten selecteren representatieve delen van de video en voegen daaraan commentaar toe waarbij opnieuw gebruik wordt gemaakt van het begrippenkader. De conceptuele structuur wordt dus niet alleen geleerd door een videocasus te analyseren, maar ook door hem te gebruiken in relatie tot het eigen handelen.

Op deze wijze wordt de bestudeerde videocasus omgevormd tot een eigen casus; het produceren van een eigen videocasus draagt bij aan een diepe verwerking van kennis 
en het opbouwen van een persoonlijke case library (Kolodner, 2006). Het gebruik van eigen videobeelden wordt ook gemotiveerd door het gegeven dat beelden van eigen gedrag als betekenisvoller worden ervaren dan beelden van een gegeven situatie en leiden tot meer motivatie en een inhoudelijker focus (Borko et al., 2008; Rosaen et al., 2008; Stockero, 2008; Van Es \& Sherin, 2008; Van Es \& Sherin 2010).

Vanwege de randvoorwaarden en de opbouw in complexiteit van de leertaken is in het eerste onderwijsarrangement gekozen voor een afwijkende authentieke taak: eerstejaars studenten voeren geen gesprek met ouders, maar brengen het communicatiebeleid van hun stageschool in kaart. In onderwijsarrangement 2 en 3 is gekozen voor semiauthentieke videobeelden en in onderwijsarrangement 4 voor authentieke videobeelden van een gesprek tussen stagiaire-leerkracht en ouders in de basisschool.

De laatste fase van het didactisch model richt zich in het bijzonder op het expliciteren van het geleerde; hiermee wordt de indexering van de videocases bevorderd, worden de cases beter opgeslagen in het geheugen en wordt de kans op transfer van het geleerde verhoogd. Het geleerde kan een breed palet beslaan van onder andere conceptuele, procedurele en conditionele kennis, opvattingen en vaardigheden. Deze laatste fase is toegevoegd aan het oorspronkelijke didactische model (van den Berg, Bakx, Thijs, \& Kemmeren, 2005), waarin toepassen en expliciteren nog als één fase werden beschouwd. Expliciteren echter kan als cognitief proces worden onderscheiden van toepassen en kent ook andere bijpassende leeractiviteiten.

In overeenstemming met de idee van case based reasoning dat kennis wordt opgeslagen in de vorm van verhalen, vindt explicitering van het geleerde plaats middels productie (en presentatie) van een eigen videocasus. Daarbij staan analyse, interpretatie en argumentatie centraal. Studenten leggen met gebruikmaking van concepten uit hoe zij de communicatieve situatie hebben opgevat, welke keuzes ze hebben gemaakt in hun professioneel handelen en welke afwegingen daaraan ten grondslag lagen. $\mathrm{Zij}$ vertonen ook eigen videobeelden waarmee zij hun communicatieve vaardigheden demonstreren, ze benoemen sterke en zwakke kanten van persoonlijke communicatieve vaardigheden en beschrijven wat ze van de casus hebben geleerd.

Het presenteren van de zelfgeproduceerde videocasus aan medestudenten biedt de mogelijkheid voor het toepassen van de concepten - en voor het bijstellen van die concepten, want studenten horen en zien elkaars interpretatie van de concepten. Ook het luisteren naar de verscheidene interpretaties van de gegeven situatie en de verschillende handelingsalternatieven geven aanleiding voor vergelijking met de eigen interpretatie en voor het vormen van een veelzijdig beeld van de situatie. Deze vorm van reflecteren op de eigen ervaring en expliciteren van het geleerde draagt bij aan het entameren van discussies onder peers en docenten en daarmee aan het sociale karakter van kennisconstructie.

De eindproducten die worden gemaakt in de vier onderwijsarrangementen verschillen onderling enigszins qua vorm vanwege de inpassing in het bestaande curriculum- en daarmee verschilt ook de wijze waarop de explicitering van het geleerde plaats vindt enigszins. In opleidingsfase 1 wordt een schriftelijke analyse van 
het communicatiebeleid in de stageschool van de student gemaakt en vindt explicitering niet plaats. In opleidingsfase 2 en 3 wordt, zoals beschreven, gewerkt met presentaties waarin plaats is voor een mondelinge reflectie. In opleidingsfase 4 wordt het geleerde tweemaal geëxpliciteerd. De afstuderende student produceert individueel een videocasus met authentieke beelden, inclusief een schriftelijke analyse en reflectie waarin geëxpliciteerd wordt wat is geleerd. Ook formuleren deze studenten gedurende het leerproces een keer mondeling wat ze hebben geleerd. In de mondelinge variant wordt voor de camera verteld wat is geleerd over communicatie, waarbij expliciet de opdracht is gegeven zich uit te drukken met behulp van concepten. Bij deze leeractiviteit proberen studenten concepten te integreren in hun mondelinge discours en deze betekenisvol te maken in relatie tot hun eigen handelen.

\section{Coöperatief leren}

Coöperatief leren is in het didactisch model een uitgangspunt. Dit komt voort uit een randvoorwaarde voor het ontwerp, namelijk aansluiten bij het bestaande curriculum van de hogeschool dat is gebaseerd op een sociaal-constructivistische kennisopvatting. Deze randvoorwaarde past inhoudelijk bij de uitgangspunten van het ontwerp - want met dit type leren kan vorm worden gegeven aan het sociale karakter van kennisconstructie. Coöperatief leren onderscheidt zich van individueel en competitief leren (Johnson \& Johnson, 2002) en kenmerkt zich door een interactieve werkwijze waarbij studenten onderling afhankelijk zijn voor het bereiken van een gemeenschappelijk leerdoel. Het meest effectief is coöperatief leren bij een opdracht die complex is en geen eenduidige oplossing kent. Coöperatief leren lijkt daarom een geschikte en zinvolle werkwijze voor een ill-structured domein zoals communicatie met ouders.

De leeractiviteiten in de vijf fasen van het didactisch model vinden afwisselend individueel en in groepsverband plaats. De verscheidene leeractiviteiten in groepsverband zijn er enerzijds op gericht studenten zoveel mogelijk kansen te bieden hun begrip van de concepten te verdiepen en bij te stellen door deze te toetsen aan de interpretaties van anderen. Sociale leeractiviteiten geven de mogelijkheid om in een proces van betekenisonderhandeling (mis)interpretaties van concepten bij te stellen, de reikwijdte van concepten te bepalen en feedback te geven en te krijgen. Dit gebeurt expliciet in de integratie- en toepassingsfase van het didactische model. Maar ook in de expliciteringsfase nemen studenten kennis van elkaars interpretaties van concepten en stellen zij hun eigen beeld ervan bij. Anderzijds zijn de leeractiviteiten gericht op het delen van persoonlijke afwegingen en interpretaties van de gegeven situatie. Samenwerken in een kleine groep draagt er toe bij dat studenten kunnen kennismaken met de inzichten en perspectieven van anderen. Kortom, de coöperatieve leertaak heeft een structurerende werking voor het samenwerken en de coöperatieve werkvormen dragen door hun interactieve karakter bij aan het leren van concepten én aan het leren interpreteren van communicatieve situaties.

In het vierde onderwijsarrangement is afgeweken van het uitgangspunt van coöperatief leren vanwege randvoorwaarden en praktische omstandigheden: het feit dat afstuderende studenten ieder op een eigen stageplaats een gesprek met ouders 
voorbereiden en uitvoeren leidt ertoe dat een coöperatieve leertaak niet uitvoerbaar is. Ook mogen afstudeerders niet worden gehinderd in hun studievoortgang door mogelijk vertragend werkende medestudenten. Desalniettemin hebben de meeste leeractiviteiten in dit onderwijsarrangement ook een sociaal en interactief karakter.

\section{Algemeen kenmerk van instructie: Kennisconstructie via interactie}

Uitgaand van het situated karakter van kennis, is het van belang dat studenten deelnemen aan een sociale en professionele omgeving waarin die kennis van belang is. Bij het leren van cases kan dit sociale aspect worden bevorderd door leeractiviteiten of 'social practices' op verschillende niveaus te ontwerpen (bijvoorbeeld met peers, docenten, professionals uit de praktijk) die uitnodigen tot interactie, uitwisseling en het geven van feedback (Kim \& Hannafin, 2008b). De leeractiviteiten in het gehele instructieontwerp creëren daarom interactie tussen verschillende groepen deelnemers aan de professionele omgeving: (a) peers onderling, (b) student en lerarenopleider en (c) student en professional in basisschool. Het bevorderen van interactie tussen peers vindt plaats door de leeractiviteiten die in de leertaak zijn genoemd, maar ook door bijvoorbeeld groepsdiscussies en peer-feedback in kleine groepen op eigen videobeelden. De interactie op het tweede niveau, tussen student en lerarenopleider, vindt plaats doordat de lerarenopleiders gedurende het leerproces doen aan 'modeling' van de analyse van een communicatieve situatie en mondelinge feedback geven op de uitgevoerde opdrachten. Dit laatste heeft ten doel mogelijke misinterpretaties van concepten bij te sturen en de voortgang van het proces te bewaken. De interactie tussen student en professional ten slotte wordt in onderwijsarrangement 1 en 4 gecreëerd: in het eerste jaar interviewt de student een leerkracht van zijn stageschool over het communicatiebeleid van de school en de uitwerking daarvan in de praktijk. In het vierde jaar doet de student een training in communicatieve vaardigheden met acteurs en krijgt hij rechtstreeks feedback op zijn handelen. Daarnaast wordt mondelinge en schriftelijke feedback door een leerkracht uit de basisschool gegeven op de uitvoering van de opdracht in de praktijk (het voeren van een gesprek met ouders).

Het doel van deze sociale leeractiviteiten is steeds het leren begrijpen en toepassen van de conceptuele structuur in relatie tot (het eigen handelen in) praktijksituaties. In een interactief proces wordt via oefening en feedback op verschillende niveaus een genuanceerd beeld gevormd van de concepten, de communicatieve situaties en mogelijke, passende handelwijzen. Hiermee wordt beoogd het professioneel handelen in goed doorgronde situaties te onderbouwen met goed begrepen concepten.

\subsubsection{Vormgeving van onderwijs en leeromgeving}

De vormgeving en organisatie van het onderwijs is beïnvloed door twee factoren. Enerzijds was het uitgangspunt onderwijs te ontwikkelen dat doelgericht, compact en 'to-the-point' is, aangezien uit studentevaluaties op de lerarenopleiding bleek dat studenten het onderwijs vaak ervaren als te langdradig. Daarom is gekozen voor een beperkte hoeveelheid plenaire colleges, relatief veel zelfstandigheid, consultatie van de docent voor het krijgen van gerichte feedback en werken aan een authentieke 
taak. De onderwijsarrangementen zijn zo georganiseerd dat studenten snel actief aan het werk zijn en feedback op maat krijgen. Anderzijds hebben randvoorwaarden de mogelijke vormgeving van het onderwijs beperkingen opgelegd: een beperkte hoeveelheid studiepunten en een navenant beperkte hoeveelheid docenttijd zijn beschikbaar. Het is daardoor dus niet mogelijk om onbeperkt colleges en/of begeleidingsmomenten te plannen.

De leeractiviteiten in de onderwijsarrangementen vinden face-to-face plaats en in ieder onderwijsarrangement is face-to-face contact tussen studenten en docent. De vier onderwijsarrangementen verschillen onderling enigszins in de vormgeving van het onderwijs, aangezien ze ingepast zijn in het bestaande curriculum van de Hogeschool. Ieder onderwijsarrangement bevat in principe de volgende elementen:
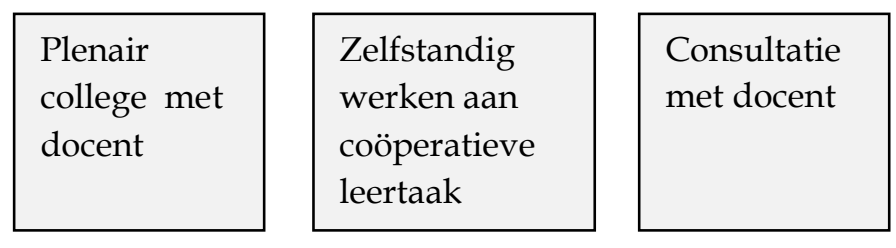
Presentatie eindproduct of inleveren eindproduct

De leeromgeving van het ontwerp is hybride en bestaat enerzijds uit digitaal toegankelijke materialen en anderzijds uit analoge materialen, zoals boeken en artikelen. In de digitale leeromgeving zijn verscheidene materialen voor studenten ondergebracht:

- videocases

- concept map met weblinks en links naar literatuur

- coöperatieve leertaken

- beoordelingscriteria ${ }^{6}$

- studiehandleiding.

De toetsing van de onderwijsarrangementen bestaat uit een beoordeling van het eindproduct. Voor docenten zijn daartoe enkele aanvullende materialen ontwikkeld. Onderwijsarrangement 1 wordt uitgevoerd door docenten met verscheidene achtergronden. Aangezien zij niet allemaal kennis hebben van communicatietheorieën, is ook een voorbeelduitwerking van de analyse-leertaak gemaakt ter ondersteuning van de beoordeling. Bij onderwijsarrangement 4 zijn voor de beoordeling behalve beoordelingscriteria ook scoringsvoorschriften geformuleerd. In Bijlage B wordt met een voorbeeld geillustreerd hoe het instructieontwerp in concreto is uitgewerkt voor studenten. Beschreven wordt een videocasus uit onderwijsarrangement 2 met de bijbehorende inhoudelijke issues, delen van de leertaak en de beoordelingscriteria.

6 De beoordelingscriteria van onderwijsarrangement 2 zijn in de eerste en een verbeterde versie ter vergelijking voorgelegd aan studenten. De feedback op de aangepaste versie was positief: studenten vonden de criteria concreter en eenvoudiger gesteld en daardoor duidelijker. De overige beoordelingscriteria zijn in het ontwerpproces ter verbetering voorgelegd aan docenten. Dit wordt beschreven in hoofdstuk 4, waar ook wordt beschreven hoe de toetsing in het ontwerpproces is geëvolueerd. 


\section{Tot slot}

In dit hoofdstuk is beschreven hoe het ontwerp binnen de gegeven randvoorwaarden voldoet aan de ontwerprichtlijnen, welke vorm het curriculum- en instructieontwerp heeft gekregen en welke keuzes daarin zijn gemaakt. Beschreven is hoe het ontwerp een leerproces faciliteert waarin, met een toenemende mate van complexiteit, conceptuele kennis en professioneel handelen aan elkaar worden verbonden door middel van het analyseren en produceren van videobeelden. Vanuit het perspectief van de cognitieve flexibiliteitstheorie wordt gesteld dat het analyseren en interpreteren van rijke videocases leidt tot cognitieve flexibiliteit. Cognitieve flexibiliteit wordt in dit onderzoek opgevat als 'beredeneerd professioneel handelen' dat als volgt is geoperationaliseerd: (a) de onderbouwing van professioneel handelen in realistische situaties met behulp van een conceptuele structuur, (b) waarbij verschillende perspectieven en (c) specifieke contextfactoren worden betrokken.

Verwacht wordt dat twee elementen van het ontwerp in het bijzonder bijdragen aan het beredeneerd professioneel handelen: Het produceren van videobeelden inclusief een verantwoording van het eigen professioneel handelen en het consequent gebruik van een conceptuele structuur bij alle leertaken. 


\section{Hoofdstuk 4}

\section{Tussen bedoeling en uitvoering: een evaluatie van het uitgevoerde curriculum}

\section{Inleiding}

Nadat in het vorige hoofdstuk het curriculum- en instructieontwerp is beschreven, wordt in de hoofdstukken 4 en 5 verslag gedaan van de formatieve evaluatie van de interventie. De formatieve evaluatie van de interventie is omvangrijk, omdat de verscheidene onderwijsarrangementen zijn geëvalueerd en omdat in een projectfase voorafgaand aan het voorliggende onderzoek, al een eerste formatieve evaluatiestudie heeft plaatsgevonden.

Dit hoofdstuk concentreert zich op de evaluatiestudie van onderwijsarrangement 2 en richt zich op de praktische bruikbaarheid. Nagegaan wordt welke ervaringen studenten en docenten hebben opgedaan met de eerste versie van de interventie om zo onderbouwde verbeteringen te genereren voor de uitvoering ervan. Om een helder beeld te geven van het stapsgewijze ontstaansproces van de interventie, wordt in dit hoofdstuk ook een beeld geschetst van het gehele evaluatieproces, waarbij samenvattingen worden gegeven van de overige formatieve evaluatiestudies en op een rijtje wordt gezet tot welke verbeteringen voor de onderwijsarrangementen ze hebben geleid.

De opbouw van dit hoofdstuk is als volgt: In de eerste paragraaf wordt een overzicht gegeven van de formatieve evaluatiestudies en wordt verantwoord waarom onderwijsarrangement 2 in het bijzonder wordt uitgelicht. Tevens wordt een beeld geschetst van het evaluatie- en implementatieproces. Paragraaf 4.2 bevat een samenvatting van de evaluatiestudie uit de projectfase en van de evaluaties van de onderwijsarrangementen 1 en 3 . Paragraaf 4.3 bevat de hoofdmoot van dit hoofdstuk. Hierin wordt verslag gedaan van de evaluatie van onderwijsarrangement 2 op basis van student- en docentervaringen. Afgesloten wordt in paragraaf 4.4 met conclusies en een overzicht van alle verbeteringen die de formatieve evaluatie heeft opgeleverd voor de uitvoering van dit onderwijsarrangement.

\subsection{Overzicht en opzet van de formatieve evaluatie}

\section{Overzicht van de formatieve evaluatiestudies}

De basis voor het curriculum- en instructieontwerp in dit onderzoek is gelegd in het Colevi-project, een ontwerp- en ontwikkelproject over Coöperatief Leren en toetsen met behulp van digitale Video in een hypermedia omgeving (Bakx \& van den Berg, 
2005). Doelstelling van dit project was om ideeën rondom competentiegericht onderwijs, coöperatief leren en leren met moderne media samen te brengen in de ontwikkeling van onderwijs over communicatieve vaardigheden voor studenten van lerarenopleidingen voor voortgezet en basisonderwijs. Binnen dit project zijn onder andere curriculummaterialen in de vorm van videocases met een aantal bijbehorende leertaken ontwikkeld en formatief geëvalueerd. $\mathrm{Na}$ afronding van de projectfase is in het voorliggende onderzoek het curriculum- en instructieontwerp verder uitgedacht en ontwikkeld.

Typerend voor ontwerponderzoek is dat het ontwerp in meerdere cycli van ontwerpen, evalueren en bijstellen tot stand komt, waarbij formatieve evaluaties dienen ter verbetering van het ontwerp (McKenney, Nieveen, \& van den Akker, 2006). In de verscheidene ontwikkel- en onderzoeksfasen van het curriculum- en instructieontwerp zijn diverse kwaliteitsaspecten van het ontwerp geëvalueerd, aansluitend bij de opbouw van formatieve evaluaties zoals Nieveen (2009) die gedetailleerd beschrijft. In de projectfase zijn met name de validiteit, de verwachte effectiviteit en de competentiegerichtheid van de curriculummaterialen geëvalueerd met behulp van een groep experts en een groep lerarenopleiders (Thijs, 2005). Ook is in deze projectfase de bruikbaarheid van de materialen met behulp van een microevaluatie met een groep studenten in kaart gebracht (Kemmeren, 2005). In de latere ontwikkel- en onderzoeksfasen is het accent in de evaluatiestudies verschoven naar de bruikbaarheid en effectiviteit van het curriculum- en instructieontwerp in de reële onderwijspraktijk en zijn deze onderzocht met behulp van try-outs. Figuur 4.1 geeft een overzicht van de verscheidene formatieve evaluaties.

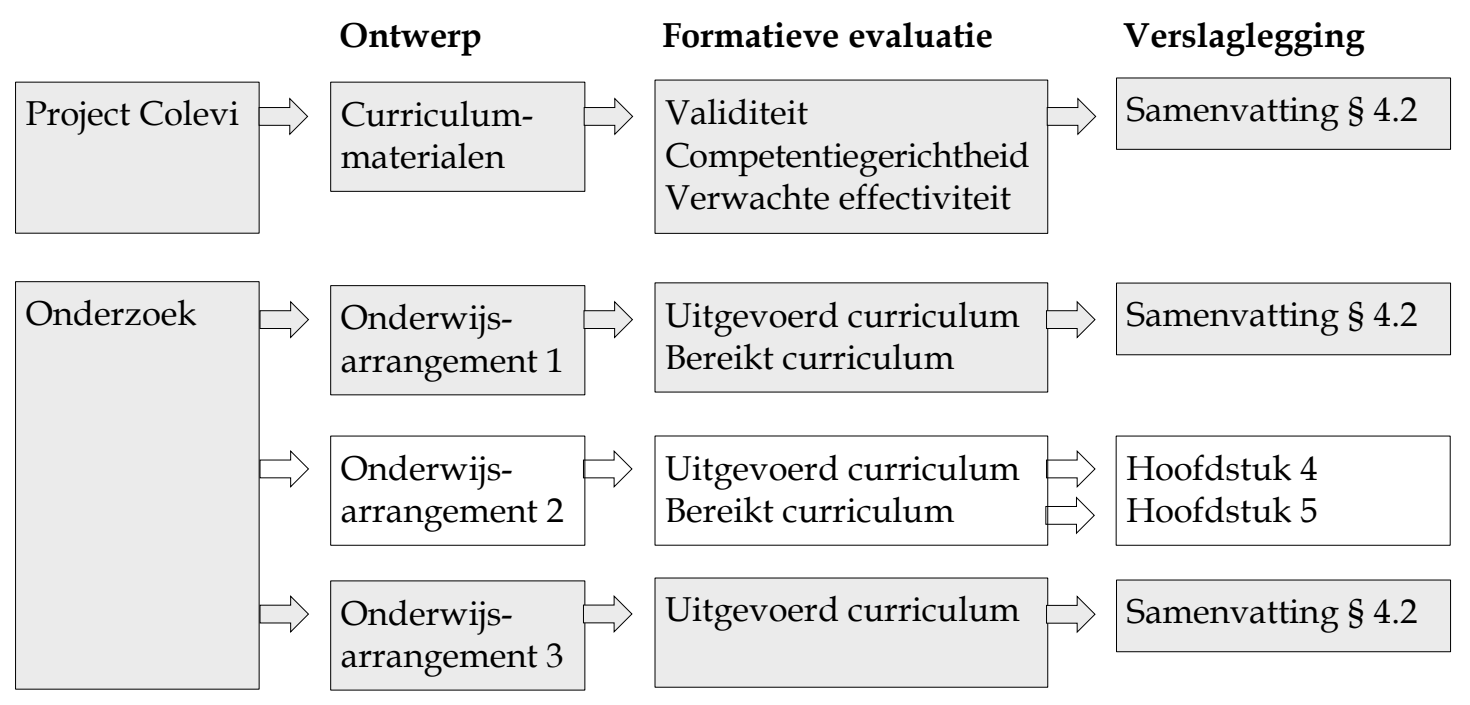

Figuur 4.1 Opzet van de formatieve evaluatie 


\section{Het proces van evaluatie en implementatie in de praktijk}

De drie onderwijsarrangementen die aanvankelijk zijn ontworpen, zijn bedoeld voor respectievelijk eerste-, tweede- en derdejaars studenten van een lerarenopleiding voor primair onderwijs. Het eerste onderwijsarrangement is ontworpen voor eerstejaars studenten en als eerste geïmplementeerd in het bestaande curriculum. Eenmaal begonnen met het geven van onderwijs in het eerste jaar van een curriculum, moet daaraan in de volgende jaren voor studenten een vervolg worden gegeven, waardoor de implementatiedruk groot is. In de volgende studiejaren zijn onderwijsarrangement 2 en 3 successievelijk ontworpen, geïmplementeerd, geëvalueerd en bijgesteld. De context waarin de onderwijsarrangementen functioneren, maakte het dus noodzakelijk ontwerpen, evalueren en implementeren te combineren. Deze werkwijze leidt ertoe dat diverse onderzoeks-, ontwerp- en implementatieactiviteiten tegelijkertijd plaatsvinden, omdat de verscheidene onderwijsarrangementen zich op een bepaald moment in verschillende stadia van ontwikkeling bevinden. In Tabel 4.1 is de complexiteit van het ontwerpen, onderzoeken en implementeren binnen een lopend curriculum verbeeld.

Tabel 4.1 Evaluatie en implementatie van drie onderwijsarrangementen

\begin{tabular}{l|l|l|l|l} 
& jaar 1 & jaar 2 & jaar 3 & jaar 4 \\
\hline Arrangement 1 & versie 1.0 & versie 1.1 & versie 1.1 & versie 1.1 \\
\hline Arrangement 2 & & versie 2.0 & versie 2.1 & versie 2.1 \\
\hline Arrangement 3 & & & versie 3.0 & versie 3.1
\end{tabular}

De vervlochtenheid van ontwerpen, implementeren, evalueren en bijstellen van verscheidene onderwijsarrangementen heeft ook gevolgen voor het ontwerpproces: Onderwijsarrangement 1.0 is het eerst geïmplementeerd en geëvalueerd. De praktische verbeteringen en inzichten die de formatieve evaluatie hiervan heeft opgeleverd zijn gebruikt om de verbeterde versie 1.1 te ontwikkelen en zijn, voor zover van toepassing, gaandeweg het ontwerpproces meteen opgenomen in het onderwijsarrangement 2.0. Hierbij gaat het met name om de rol van de docent bij het uitleggen van concepten en om de toegankelijkheid van materialen in de elektronische leeromgeving. Op dezelfde wijze zijn ook enkele verbeteringen die de evaluatie van onderwijsarrangement 2.0 heeft opgeleverd niet alleen verwerkt in versie 2.1, maar ook in onderwijsarrangement 3.0. Dit betreft met name verbeteringen rondom de toetsingsprocedure.

Het feit dat ontwerp en evaluatie tegelijkertijd plaatsvinden met grootschalige implementatie, stelt hoge eisen aan de bruikbaarheid van de onderwijsarrangementen. Vanwege de betrokkenheid van diverse docenten en honderden studenten moet versie .0 in ieder geval werkbaar zijn voor de gebruikers. De formatieve evaluatie is gebaseerd op daadwerkelijke uitvoering van het ontwerp in de praktijk - en niet op een laboratoriumsituatie of een uitvoering met een selecte groep studenten - wat leidt tot een reëel beeld van de uitvoering van het arrangement en tot onderbouwde verbeteringen voor de uitvoering van de volgende versie (.1) 


\section{I nhoud en verslaglegging van de formatieve evaluatie}

De drie onderwijsarrangementen zijn achtereenvolgens geëvalueerd in een proces waarbij verschillende accenten zijn gelegd. De onderwijsarrangementen 1 en 2 zijn uitgebreid geëvalueerd teneinde tot praktische verbeteringen voor de uitvoering én tot inzicht in de potentiële effectiviteit van het ontwerp te komen. Deze formatieve evaluaties richten zich daarom op twee aspecten van het ontwerp:

- de relatie tussen beoogd en uitgevoerd curriculum. Met behulp van student- en docentervaringen wordt in kaart gebracht in hoeverre het uitgevoerde curriculum voldoet aan het beoogde curriculum en worden verbeteringen voor de optimalisering van de uitvoering van het onderwijsarrangement gegenereerd. De praktische bruikbaarheid van het ontwerp wordt op deze wijze geëvalueerd.

- de relatie tussen beoogd en bereikt curriculum. Door bereikte resultaten te betrekken in de formatieve evaluatie wordt nagegaan in hoeverre het ontwerp leidt tot de beoogde resultaten. De potentiële effectiviteit van het ontwerp wordt op deze wijze geëvalueerd.

In de evaluatie van onderwijsarrangement 3 is volstaan met een minder uitgebreide en formele werkwijze, aangezien uitgebreide evaluaties reeds zijn uitgevoerd en het derde arrangement gestoeld is op dezelfde uitgangspunten.

De verslaglegging van de formatieve evaluatie concentreert zich op het tweede onderwijsarrangement. Aan deze keuze ligt een inhoudelijke motivatie ten grondslag: in onderwijsarrangement 2 gaat het om de fase van advanced learning waarop de cognitieve flexibiliteitstheorie zich richt - in tegenstelling tot het voorafgaande onderwijsarrangement 1 waarin sprake is van een inleiding in het vakgebied. Bovendien zijn in onderwijsarrangement 2 alle elementen van het didactisch model volledig uitgewerkt. De evaluatie van dit onderwijsarrangement levert dan ook mogelijk veel aanwijzingen op voor verbetering én inzicht in de potentie van het ontwerp.

In het voorliggende hoofdstuk wordt het eerste deel van de formatieve evaluatie beschreven, dat wil zeggen dat de relatie tussen beoogd en uitgevoerd curriculum centraal staat. In hoofdstuk 5 wordt het tweede deel van de formatieve evaluatie beschreven waarin de relatie tussen beoogd en bereikt curriculum wordt onderzocht. Mede omwille van de leesbaarheid wordt van de projectfase en van onderwijsarrangement 1 en 3 in hoofdlijnen beschreven hoe de evaluatie is aangepakt en tot welke verbeteringen deze heeft geleid in paragraaf 4.2.

\subsection{Samenvatting formatieve evaluaties}

\section{Voorgaande projectfase}

Binnen het Colevi-project zijn onder andere curriculummaterialen in de vorm van videocases met bijbehorende leertaken ontwikkeld. In de projectfase zijn deze producten met behulp van een micro-evaluatie met studenten in de praktijk uitgetest (Kemmeren, 2005) en heeft een formatieve evaluatiestudie van de producten 
plaatsgevonden met behulp van een groep experts (met verschillende expertisegebieden) en een groep lerarenopleiders (Thijs, 2005). Het doel van deze studie was om zicht te krijgen op de kwaliteit van de producten en suggesties ter verbetering te genereren. Deze evaluatiestudie is met name ingegaan op (a) de validiteit, ofwel de mate waarin de videocases inclusief leertaak zijn gebaseerd op de ontwerpprincipes, (b) de competentiegerichtheid en curriculaire inbedding, ofwel de mate waarin de videocases inclusief leertaak opgenomen kunnen worden in een competentiegericht curriculum en (c) de verwachte effectiviteit, ofwel de mate waarin de videocases inclusief leertaak een bijdrage kunnen leveren aan de ontwikkeling van communicatievaardigheden.

De evaluatiestudie laat zien dat de uitgangspunten van het Colevi-project breed worden onderschreven. Het uitgangspunt 'coöperatief leren met behulp van video binnen competentiegericht opleiden' wordt beschouwd als een veelbelovende idee. De validiteit van de producten is positief beoordeeld: de ontwerpprincipes hebben een duidelijke vertaling gevonden in de materialen en de validiteit van de producten is dan ook voldoende gegarandeerd.

Verder zijn de producten goed in te passen in een competentiegericht curriculum en vormen ze een basis voor coöperatief leren. Om de potentie van deze curriculaire inbedding ten volle te realiseren, worden echter wel verbetersuggesties gegeven. Het is nodig om studenten meer ondersteuning te geven bij het uitvoeren van coöperatieve leerprocessen en om de leertaken beter te structureren.

Wat betreft de verwachte effectiviteit zijn de experts van mening dat de producten de potentie hebben om bij te dragen aan het ontwikkelen van communicatieve vaardigheden. De effectiviteit zou kunnen worden vergroot door meer en gerichter aandacht te besteden aan concepten uit de communicatiewetenschap. De rol van deze conceptuele kennis in de leertaken moet verder worden doordacht: Het is belangrijk om conceptuele kennis aan te bieden, maar de vraag is hoeveel, op welk moment in de leertaak en met welk doel. Naast deze verbeteringen zijn nog talrijke suggesties ter verbetering gegeven die op meer gedetailleerd niveau liggen (zie Thijs, 2005).

De evaluatie heeft, behalve een oordeel over de kwaliteit van de videocases inclusief leertaak en mogelijkheden ter verbetering daarvan, ook twee meer fundamentele discussiepunten opgeworpen. De eerste vraag is of studenten zich voorafgaand aan de analyse van de videocasus meer zouden moeten verdiepen in conceptuele kennis. De experts verschillen hierover van mening: de inhoudelijk deskundigen vinden dat eerst een conceptuele structuur moet worden verworven voordat een casus van een praktijksituatie wordt bekeken. De didactisch deskundigen zijn van mening dat het juist goed is eerst de praktijksituatie te bekijken en daarna te gaan analyseren met behulp van een begrippenkader.

Het tweede discussiepunt betreft de selectie van cases en het gebruik van realistische voorbeelden. De experts verschillen van mening over de vraag of het verstandig is videocases met 'slechte voorbeelden' te tonen, vanwege het ongewenste leereffect dat daar vanuit zou kunnen gaan. De discussie heeft geleid tot keuzes op beide punten. In het gehanteerde didactisch model bekijken studenten eerst een praktijksituatie en bediscussiëren deze; pas daarna vindt verdieping in de conceptuele structuur plaats 
om tot een analyse van de videocasus te komen. Verder worden realistische, maar niet evident 'slechte' voorbeelden gebruikt.

Kortom, deze eerste formatieve evaluatie heeft de levensvatbaarheid van het instructieontwerp aangetoond. De kwaliteitsbeoordeling heeft laten zien dat de uitgangspunten van het Colevi-project nastrevenswaardig zijn en dat de videocases inclusief leertaak voldoende kwaliteit bezitten om verder te worden uitgewerkt. Tevens heeft de evaluatie geleid tot concrete verbeteringen van de curriculummaterialen en een aanscherping van het achterliggende gedachtegoed.

\section{Onderwijsarrangement 1 en 3}

Onderwijsarrangement 1 vormt een inleiding in het onderwerp 'communiceren met ouders' waarbij eerstejaars studenten kennismaken met concepten uit de communicatiekunde. De doelstelling van de evaluatiestudie was tweeledig: (a) inzicht verwerven in de manier waarop studenten en docenten het onderwijsarrangement hebben uitgevoerd om verbeteringen voor de uitvoering te genereren en (b) een indicatie te verkrijgen van de mate waarin studenten conceptuele kennis hebben toegepast in de leertaak. In het licht van de doelstelling van het gehele ontwerp - het verbinden van conceptuele kennis en professioneel handelen - is in deze formatieve evaluatie speciaal aandacht besteed aan de manier waarop studenten omgaan met het bestuderen van theorie, aan de student- en docentperceptie van de leeropbrengst en aan de toepassing van de conceptuele structuur bij de analyse van een communicatieve situatie.

De belangrijkste verbeteringen hebben betrekking op het verwerven van de conceptuele structuur, de aanpak van de opdracht en de studiebegeleiding. Studenten kunnen de (beperkte) conceptuele structuur niet zelfstandig verwerven, maar hebben meer inhoudelijke uitleg nodig van een docent voor het doorgronden van de begrippen. Daarnaast is het van belang studenten een reëel beeld te geven van het gewenste niveau van de opdracht door aandacht te besteden aan de manier waarop conceptuele kennis verwerkt moet worden in de taak en uitleg te geven over de functie van theorie. Een deel van de studenten heeft procedurele studiebegeleiding nodig op het gebied van planning.

Onderwijsarrangement 3 is bedoeld voor derdejaars studenten. In deze fase maakt communicatie deel uit van een grotere, thematisch samenhangende onderwijseenheid waarin vier vakgebieden worden samengebracht en gezamenlijk getoetst. Doelstelling van de evaluatie is verbeteringen voor de uitvoering te genereren en inzicht te verkrijgen in de ervaren leeropbrengst.

De evaluatie levert diverse gedetailleerde, praktische verbeteringen op voor de uitvoering van het onderwijsarrangement, maar ook een wezenlijke verbetering van het ontwerp. Gebleken is uit docent- en studentevaluaties dat de ontwikkeling van communicatieve vaardigheden geen gelijke tred hield met de ontwikkeling van de analytische vaardigheden en meer aandacht vergt. Een authentieke(re) oefencontext (dan samenwerken met medestudenten in een rollenspel) zou hiervoor motiverend 
zou kunnen werken. In het licht van de bedoeling van het gehele ontwerp - het verbinden van conceptuele kennis en praktisch handelen om professioneel gedrag te stimuleren - is het belangrijk in de onderwijsarrangementen een evenwicht te vinden tussen aandacht voor conceptuele kennis en aandacht voor de ontwikkeling van vaardigheden. Daarom is een vierde onderwijsarrangement ontworpen, waarin communicatieve vaardigheden worden geoefend in een semi-authentieke context (een communicatietraining met acteurs) én in de authentieke context van de basisschoolpraktijk (een gesprek met ouders). De curriculaire randvoorwaarden maakten het niet mogelijk deze wijziging in arrangement 3 in te voeren. Bovendien verzocht het management van de hogeschool naar aanleiding van intern evaluatieonderzoek, om ook onderwijs voor vierdejaars studenten in de afstudeerfase te ontwerpen over communicatie met ouders. Dit heeft geleid tot de toevoeging van een vierde onderwijsarrangement aan het oorspronkelijke ontwerp. In Tabel 4.2 wordt een overzicht gegeven van de opzet van beide evaluatiestudies en de belangrijkste verbeteringen die ze hebben opgeleverd voor optimalisering van de onderwijsarrangementen.

Tabel 4.2 Samenvatting van formatieve evaluatie onderwijsarrangement 1 en 3

\begin{tabular}{|c|c|c|}
\hline & Arrangement 1 & Arrangement 3 \\
\hline Deelnemers & $\begin{array}{l}\text { Studenten: } 325 \\
\text { Docenten: } 18 \\
\text { 1e-jaars Pabostudenten } \\
\text { Zelfstandige onderwijseenheid }\end{array}$ & $\begin{array}{l}\text { Studenten: } 184 \\
\text { Docenten: } 12 \\
\text { 3e-jaars Pabostudenten } \\
\text { Onderwijseenheid in samenhang met } \\
\text { drie andere vakgebieden }\end{array}$ \\
\hline $\begin{array}{l}\text { Evaluatie- } \\
\text { methode }\end{array}$ & $\begin{array}{l}\text { Evaluatie van praktische } \\
\text { bruikbaarheid op basis van: } \\
\text { Interviews studenten (9) } \\
\text { Interviews docenten (4) } \\
\text { Evaluatie van potentiële } \\
\text { effectiviteit op basis van: } \\
\text { Analyse leerresultaten } \\
\text { studenten (3) }\end{array}$ & $\begin{array}{l}\text { Evaluatie van praktische bruikbaarheid } \\
\text { op basis van: } \\
\text { Interviews studenten (7); } \\
\text { Evaluatiebijeenkomst docenten; } \\
\text { Mondelinge evaluatie studenten; } \\
\text { Observaties van onderzoeker tijdens } \\
\text { groepspresentaties; }\end{array}$ \\
\hline Verbeteringen & $\begin{array}{l}\text { Inhoud/leeropbrengst } \\
\text { Toelichting geven op theorie } \\
\text { door docent; } \\
\text { Verhelderen van verwacht } \\
\text { niveau m.b.v. voorbeelden; } \\
\text { Uitleg geven over functie van } \\
\text { theorie. }\end{array}$ & $\begin{array}{l}\text { Inhoud/leeropbrengst } \\
\text { Samenhang inhouden verhelderen; } \\
\text { Inhouden deels aanpassen en beperken } \\
\text { om diepgang te bewerkstelligen; } \\
\text { Demonstreren van samenhang en } \\
\text { gebruik van verschillende theoretische } \\
\text { invalshoeken; } \\
\text { Meer aandacht voor oefening } \\
\text { communicatieve vaardigheden; } \\
\text { Meer contacttijd voor verdieping; }\end{array}$ \\
\hline
\end{tabular}


Tabel 4.2 Samenvatting van formatieve evaluatie onderwijsarrangement 1 en 3 (Vervolg)

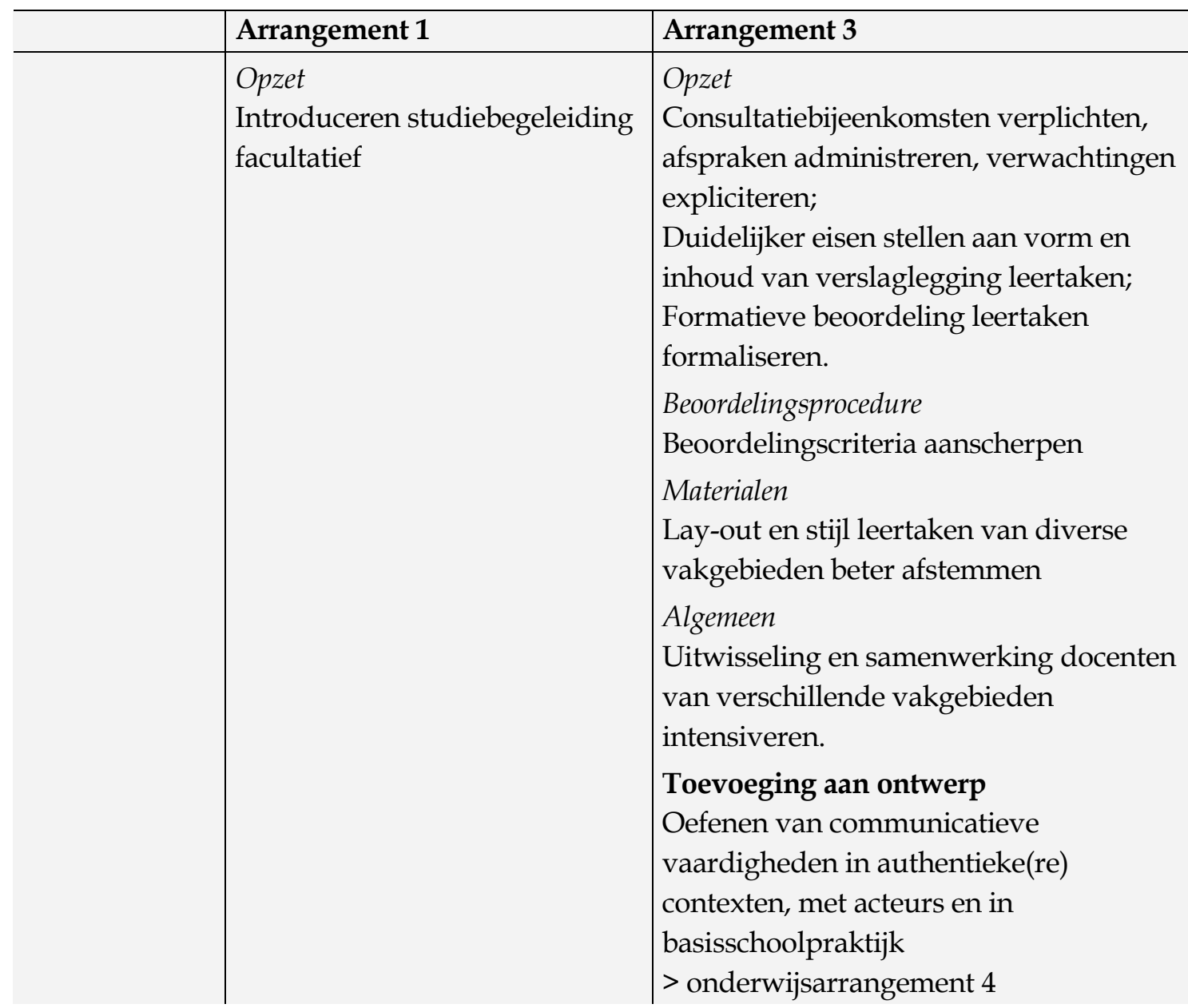

\section{Tot slot}

De formatieve evaluaties hebben geleid tot diverse verbeteringen voor de uitvoering van de onderwijsarrangementen en tot een wezenlijke toevoeging aan het ontwerp. De ontwikkeling van communicatieve vaardigheden komt beter tot zijn recht als studenten niet alleen met medestudenten oefenen, maar ook in een context die meer spanning en motivatie oproept. Een semi-authentieke en een authentieke context zijn daarom toegevoegd aan het curriculumontwerp in een volgend onderwijsarrangement.

De toevoeging van een onderwijsarrangement aan het ontwerp betekent ook dat het evaluatie- en implementatieproces in tijd is verlengd en in complexiteit is toegenomen. Tabel 4.1 is dan ook uitgebreid met een extra jaar, zoals in Tabel 4.3 is aangegeven

Tabel 4.3 Evaluatie en implementatie van vier onderwijsarrangementen

\begin{tabular}{l|l|l|l|l|l} 
& jaar 1 & jaar 2 & jaar 3 & jaar $\mathbf{4}$ & jaar $\mathbf{5}$ \\
\hline Arrangement 1 & versie 1.0 & versie 1.1 & versie 1.1 & versie 1.1 & versie 1.1 \\
\hline Arrangement 2 & & versie 2.0 & versie 2.1 & versie 2.1 & versie 2.1 \\
\hline Arrangement 3 & & & versie 3.0 & versie 3.1 & versie 3.1 \\
\hline Arrangement 4 & & & & versie 4.0 & versie 4.1
\end{tabular}




\subsection{Formatieve evaluatie van het uitgevoerde curriculum}

\section{Inleiding}

De formatieve evaluatie van onderwijsarrangement 2 heeft als doel tot onderbouwde verbeteringen van het arrangement te komen en de praktische bruikbaarheid ervan te vergroten. Daarvoor is het van belang inzicht te krijgen in de manier waarop het onderwijsarrangement in de praktijk wordt uitgevoerd. De centrale vraag in deze studie is in hoeverre het uitgevoerde curriculum overeenkomt met het beoogde curriculum. Om gedetailleerd inzicht te krijgen in de manier waarop het onderwijsarrangement is uitgevoerd door studenten en docenten zijn gebruikerservaringen in kaart gebracht. Voor de evaluatie is een kwalitatieve onderzoeksmethode gehanteerd vanwege de grote informatierijkdom die deze werkwijze oplevert, waardoor de resultaten zich laten vertalen in bruikbare aanwijzingen voor verbetering. De studie kan gekarakteriseerd worden als een meervoudige gevalsstudie (Yin, 2009).

\subsubsection{Onderzoeksmethode}

\section{Onderzoeksvraag}

In deze studie wordt eerst nagegaan hoe studenten en docenten het onderwijsarrangement uitvoeren en welke mogelijkheden zij zien voor verbetering van de uitvoering. Voor de evaluatie van de uitvoering van het onderwijsarrangement luidt de onderzoeksvraag voor studenten: Welke ervaringen hebben studenten opgedaan met de inhoud, de opzet, de werkwijze, beoordelingsprocedure en de materialen van het onderwijsontwerp en welke verbeteringen dragen zij aan?

Voor docenten luidt de onderzoeksvraag: Welke ervaringen hebben docenten opgedaan met de inhoud, de beoordelingsprocedure en de materialen van het onderwijsarrangement en welke verbeteringen dragen zij aan?

De gebruikerservaringen zijn in kaart gebracht met interviews die gedetailleerd inzicht geven in de manier waarop studenten en docenten met het onderwijsontwerp hebben gewerkt en hoe zij het hebben ervaren. Op basis van deze gegevens vindt een vergelijking plaats van het uitgevoerde en het beoogde curriculum, waarbij wordt onderzocht in hoeverre het onderwijsarrangement is uitgevoerd conform de bedoeling van het ontwerp. Verbeteringen om de praktische bruikbaarheid van het onderwijsarrangement te optimaliseren zijn vervolgens afgeleid; de verbetersuggesties van studenten en docenten zijn ook beoordeeld in het licht van optimalisering van de praktische bruikbaarheid. Door Doyle en Ponder (1977-1978) worden in het begrip praktische bruikbaarheid drie dimensies onderscheiden: instrumentality, congruence en cost. Met instrumentaliteit wordt verwezen naar de procedurele kant van het onderwijsarrangement: Is het duidelijk wat er gedaan moet worden? Valt ermee te werken? De dimensie congruentie verwijst naar de mate waarin de onderwijsvernieuwing overeenstemt met de percepties en de opvattingen 
van de uitvoerder over onderwijs en leren. De dimensie kosten tenslotte verwijst naar de verhouding tussen kosten en baten, dat wil zeggen: is het onderwijsarrangement, of zijn delen ervan, de moeite waard om energie in te steken? In deze studie wordt gefocust op het aspect instrumentaliteit.

\section{Participanten}

Het onderwijsarrangement is geïmplementeerd in het curriculum van een lerarenopleiding en uitgevoerd in 2006-2007 door 200 tweedejaarsstudenten en 2 docenten Nederlands in twee opleidingstrajecten: In een versneld opleidingstraject met 35 studenten en in het reguliere opleidingstraject met 165 studenten. Beide groepen hebben hetzelfde arrangement doorlopen.

Alle studenten zijn tijdens de toetsing mondeling geïnformeerd over het feit dat er onderzoek wordt gedaan naar de relatie tussen theorie en handelen. Onder studenten uit het reguliere opleidingstraject is een oproep gedaan per email om hun ervaringen te delen. Voor deze groep studenten is gekozen omdat hun opleidingsachtergrond het meest overeenkomt met de opleidingsachtergrond van de grootste groep Pabostudenten (havo en mbo). De studenten uit het versnelde opleidingstraject hebben vrijwel allemaal een vwo-achtergrond. Tien studenten hebben gereageerd op de oproep en daarvan zijn er zes at random geselecteerd voor een interview. Vijf studenten volgen de voltijdopleiding (leeftijd varieert van 19 tot 23 jaar), één student volgt de vierjarige deeltijdopleiding (leeftijd 35 jaar). De vooropleiding van de voltijdstudenten is havo, van de deeltijdstudent meao.

De twee betrokken docenten Nederlands verleenden onmiddellijk hun medewerking aan het verzoek om een evaluatie en zijn beide geïnterviewd. De docenten hebben beide ruime onderwijservaring ( 20 en 13 jaar), maar verschillen in ervaring als docent in de lerarenopleiding: de één heeft 13 jaar ervaring, de ander nog geen jaar.

\section{Dataverzameling en procedure}

Voor het inventariseren van de gebruikerservaringen zijn gegevens verzameld door middel van half-gestructureerde interviews met studenten en docenten.

Drie weken na afloop van het onderwijsarrangement zijn individueel, face-to-face, halfgestructureerde interviews van een half uur à drie kwartier afgenomen bij zes studenten. Het interview bevat vragen naar feitelijk gedrag, waardering en verbetersuggesties. In het interviewschema zijn de volgende onderwerpen aan bod gekomen:

1. Leeropbrengst en motivatie voor casus

2. Opzet (vormgeving van de module in plenaire en niet-plenaire bijeenkomsten)

3. Werkwijze (conceptuele verdieping, presentatie voorbereiden, samenwerking)

4. Beoordelingsprocedure

5. Materialen

6. Algemene indruk.

In het interviewschema is zoveel mogelijk een chronologische volgorde aangehouden, dat wil zeggen dat de vragen zijn geordend volgens de fasen van het onderwijsarrangement zoals de student die ervaart. 
Met de twee betrokken docenten is het onderwijsarrangement van tevoren uitvoerig besproken, omdat het een nieuw onderdeel in het curriculum betreft. Eén week na de uitvoering is een half-gestructureerd interview van een uur gehouden met beide docenten tegelijk. Eén van hen had op eigen initiatief de onderzoeker al een schriftelijke evaluatie toegestuurd. Gevraagd is naar de manier waarop de docenten het onderwijsarrangement hebben uitgevoerd, welke leeropbrengst zij ervaren voor studenten, hoe zij het onderwijsarrangement waarderen en welke verbeteringen zij aandragen.

Het interviewschema voor docenten bevat vragen over de volgende onderwerpen:

1. Leeropbrengst

2. Materialen

3. Beoordelingsprocedure

4. Algemene indruk en verwachtingen.

De interviewschema's voor studenten en docenten zijn opgenomen in Bijlage C en D.

\section{Dataverwerking en -analyse}

De audiobestanden van de interviews met studenten en docenten zijn volledig getranscribeerd. Daarna zijn de gegevens eerst per onderwerp gerubriceerd en daarna samengevat. De samenvatting is toegelicht met citaten die de ervaringen van studenten en docenten illustreren. Tenslotte zijn in een interpretatief proces de bevindingen vergeleken met de bedoeling van het onderwijsarrangement en is op basis van die vergelijking nagegaan welke consequenties afgeleid kunnen worden voor verbetering van het onderwijsarrangement.

Bij het afleiden van verbeteringen uit de bevindingen is de volgende werkwijze gehanteerd. De verbetersuggesties die de participanten zelf expliciet hebben aangedragen, zijn door de onderzoeker gewogen op basis van de vraag: Leidt het verbetervoorstel tot een uitvoering van het onderwijsarrangement zoals bedoeld? Vervolgens is nagegaan of het verbetervoorstel haalbaar is binnen de gegeven randvoorwaarden. Mocht het verbetervoorstel niet haalbaar zijn, dan is een alternatief gezocht dat wel haalbaar is. Deze werkwijze levert drie mogelijke behandelingen op van verbetersuggesties: (a) overnemen, (b) afwijzen of (c) aanpassen aan de randvoorwaarden.

Behalve verbeteringen die voortkomen uit de beoordeling van expliciet geformuleerde verbetervoorstellen door de participanten, zijn ook door de onderzoeker verbeteringen afgeleid uit de bevindingen. Als uit de ervaringen van docenten en studenten bleek dat het onderwijsarrangement suboptimaal werd uitgevoerd of knelpunten opleverde waarvoor geen expliciete verbetervoorstellen werden gedaan, heeft de onderzoeker zelf een verbetering geformuleerd.

De resultaten van de interviews met studenten en docenten zijn per onderwerp als volgt weergegeven:

- Samenvatting van de gegevens

- Uitwerking: toelichting op de gegevens met citaten

- Interpretatie: consequenties en verbeteringen voor het onderwijsontwerp. 
In de verslaglegging worden de studenten aangeduid met gefingeerde namen: de vijf voltijdstudenten heten Wendy, Leanne, Nicole, Nick en Karla, de deeltijdstudent heet Sas. De docenten worden aangeduid met de gefingeerde namen Joe en Lea.

\subsubsection{Resultaten studenten}

\subsubsection{Leeropbrengst en motivatie voor casus}

Gevraagd is waarom een bepaalde casus werd kozen en wat ervaren wordt als leeropbrengst.

\section{Samenvatting}

Studenten formuleren leeropbrengsten op diverse gebieden: kennis, handelingsrepertoire, attitude, bewustwording en samenwerking. Het accent ligt per individu anders.

Eén docent heeft de keuze van de cases niet helemaal vrij gelaten. Twee studenten hebben zich laten leiden door de docent, maar vonden dat geen probleem. De andere studenten baseren hun keuze op de verwachting een dergelijke situatie in de praktijk tegen te komen, hebben zelf ervaring met een dergelijke situatie en wisten daar geen raad mee of kennen de ervaring van een medestudent. Vooral bij de agressieve ouder speelt 'spanning' een rol bij de keuze.

\section{Uitwerking}

De toegenomen kennis die wordt benoemd, bestaat uit: achtergrond van agressie en emoties, communicatieve en beleidsdoelen en het communicatiemodel en -proces. Kennis van de achtergrond van emoties en agressie leidt tot meer begrip voor de ouder en professioneler reacties. Leanne: 'Ik snap best dat sommige mensen vanuit de eerste emotie erg kwaad kunnen reageren. Hun eerste gevoel komt naar boven en dat reageren ze direct af. Maar als je dat weet, dan kun je ook denken: Ach, diegene meent het niet zo. Als ik er even rustig mee praat, komt het wel goed. Dan weet je ook dat het emotionele agressie is en dat het wel goed komt. Of je weet dat sommige mensen echt agressief kunnen zijn en dat het echt verkeerd kan aflopen.' Wendy formuleert het nut van kennis als volgt: 'Je hebt je gewoon beter verdiept in de theorie en daarom kun je er ook logischer over nadenken. Dan gaat het allemaal wat soepeler als het daadwerkelijk echt gebeurt.' Eén student, Nick, betwijfelt of je over communicatie iets kunt leren, want 'een beetje sociaal omgaan met elkaar en respect betonen komt vanuit jezelf en niet uit een boekje'. Ook zal het 'in het echt' misschien anders gaan. Toch noemt hij enkele concepten en wijst hij erop dat nadenken over een dilemma én oefenen zinvol is.

Het nut van oefenen wordt gedeeld door de overige studenten. Hoewel de situatie gefingeerd is, wordt het oefenen toch als zinvol ervaren. Karla wijst op haar veranderde attitude en toegenomen zelfverzekerdheid: 'Eerst durfde ik dat niet in de stage. $\mathrm{Nu}$ weet je waarom je het doet en dat je een keer moet doorpakken en hoe je dat moet doen op een redelijk subtiele manier.' Ze heeft hierbij veel geleerd van haar 
medestudenten. Het toegenomen handelingsrepertoire in de vorm van gespreksvaardigheden wordt benoemd: gesprek voeren, gesprek beginnen, inspelen op situatie en het stappenplan bij agressie.

De deeltijdstudent benadrukt vooral de bewustwording van de rol van leerkracht en de meerwaarde van samenwerking en kennis, zij wijst minder op een toename van haar eigen vaardigheden. Sas geeft aan dat opdrachten vaak geschreven lijken voor jongere studenten. Toch vindt zij deze opdracht nuttig voor deeltijdstudenten, omdat die onderling erg verschillen in gesprekservaring en in samenwerkingsvaardigheden. Voor zichzelf vindt ze de opdracht een nuttige oefening.

\section{I nterpretatie}

De ervaren leeropbrengsten op het gebied van kennis en handelingsrepertoire komen overeen met de leerdoelen van het onderwijsarrangement. Leeropbrengsten op het gebied van attitude, samenwerking en bewustwording werden niet expliciet verwacht, maar worden beschouwd als gewenst neveneffect. Niet alle studenten rapporteren dezelfde leeropbrengsten. Deze verschillen in ervaren leeropbrengsten kunnen samenhangen met de verwachtingen en voorkennis van studenten. Wendy, Nicole en Leanne, de drie studenten met hoge verwachtingen, vinden dat ze veel hebben geleerd. Deze studenten kozen het onderwerp 'agressieve ouder'. Karla verwachtte niet veel te leren, maar dat bleek anders uit te pakken. $\mathrm{Zij}$ heeft veel geleerd dat toepasbaar is in haar stage. Nick had weinig en ongearticuleerde verwachtingen. Hij benoemt weinig leeropbrengsten. Sas, de deeltijdstudent had onduidelijke verwachtingen en meer voorkennis dan de overige studenten; zij heeft al veel ervaring met communicatie via haar werk en vorige opleiding. Ze benoemt toch leeropbrengsten op het gebied van kennis, bewustwording en samenwerking.

Vier studenten wijzen erop dat kennis van concepten hun communicatieve gedrag ondersteunt. Nick ziet weinig meerwaarde van de theorie en Karla schrijft haar veranderde attitude en verbeterde communicatieve handelingsrepertoire uitsluitend toe aan uitwisseling en oefening met haar medestudenten. Hieruit wordt opgemaakt dat de bedoeling van het onderwijsarrangement, namelijk het verbinden van conceptuele kennis aan professioneel handelen, door een deel van de studenten bewust wordt beleefd en door een deel niet.

Een andere mogelijke oorzaak voor verschillen in ervaren leeropbrengsten is besloten in het onderwerp van de casus. Agressie in een gesprek is een spannend onderwerp waarmee de meeste studenten weinig ervaring hebben. Het ervaren leereffect van een verdieping in dit onderwerp is in deze context misschien groter dan het ervaren leereffect van een verdieping in een minder spectaculaire gesprekssituatie.

Ten slotte konden niet alle studenten vrij kiezen welke casus ze wilden bestuderen. Mogelijk heeft dit invloed gehad op de ervaren leeropbrengst.

$>$ Verbetering: De ervaren leeropbrengst kan toenemen door een vrije keuze van de te bestuderen casus te bevorderen. Dit vergt een explicitering in de docentenhandleiding en instructie aan de uitvoerende docenten. 


\subsubsection{Opzet van het onderwijsarrangement}

Gevraagd is naar ervaringen met de vormgeving van de module in (plenaire) contacttijd.

\section{Samenvatting}

De studenten zijn enthousiast over de gehele opzet van het onderwijsarrangement: helder, bondig, gestructureerd met voldoende vrijheid. De vastgestelde planning wordt positief gewaardeerd en voorkomt uitstelgedrag. De drie contactmomenten worden beoordeeld op hun merites: Het college vormt een goede introductie op de opdracht, de consultatie is nuttig om de voortgang te checken en als voorbereiding op de presentatie, de presentatie is motiverend. Tussentijdse bereikbaarheid van de docent wordt positief gewaardeerd. De mogelijkheid van extra, facultatief consultatiemoment wordt geopperd.

\section{Uitwerking}

De opzet van het onderwijsarrangement wordt door de studenten positief gewaardeerd. Zij ervaren een goede balans tussen sturing en zelfstandigheid. De vastgestelde planning van consultatie en toetsing heeft een positief effect op de studieplanning: uitstelgedrag wordt voorkomen en alle zes studenten hebben de opdracht op het vastgestelde moment afgerond. Dit is voor de helft van hen ongebruikelijk: Karla, Nicole en Nick hebben grote moeite met zelfstandige studieplanning. De andere helft heeft uit zichzelf al een zelfstandige studiehouding; zij waarderen vooral de duidelijkheid. Het onderwijsarrangement is, in het kader van de kwaliteitszorg van de hogeschool, genoemd als goed voorbeeld.

De contacttijd is efficiënt. Het college vormt heldere introductie op de opdracht: studenten weten wat ze moeten doen. De consultatie werkt als middel om de voortgang, diepgang en uitwerking van de opdracht te bewaken. Dit werkt enerzijds goed voor de kwaliteitsbewaking, anderzijds voor het zelfvertrouwen waarmee studenten de presentatie voorbereiden. Tussentijdse beschikbaarheid van de docent, middels email of live contact wordt positief gewaardeerd. Deze vorm van just-intime-informatie voorkomt demotivatie door inefficiënte plenaire bijeenkomsten.

\section{Interpretatie}

Verwacht werd een positieve waardering van de (compacte) opzet van het onderwijsarrangement en de gerichte begeleiding in de vorm van consultatie, maar de mate waarin de opzet sturend werkt voor de studieplanning van zwakke planners, is verrassend. Voor de opzet van het onderwijsarrangement is één voorstel voor verbetering gedaan: een extra, facultatieve consultatie inlassen.

> Verbetering: In overleg met de docenten is bepaald hoe op maat extra begeleiding van de studenten het meest efficiënt vormgegeven kan worden. Gekozen is voor digitaal contact, omdat de werkbelasting van docenten, gezien de randvoorwaarden, beperkt moet blijven en omdat de studenten hiermee op maat begeleiding krijgen. 


\subsubsection{Werkwijze in het onderwijsarrangement}

Gevraagd is naar de manier van werken bij de verscheidene onderdelen van de opdracht: conceptuele verdieping, het maken van de videobeelden en de voorbereiding van de gezamenlijke presentatie. Daarnaast is gevraagd naar de wijze van samenwerking en het eventuele leereffect ervan.

\section{Samenvatting}

Het maken van de videobeelden is motiverend en plezierig voor alle studenten. De aanpak van de conceptuele verdieping en het maken van de videobeelden is zeer verschillend: Vier studenten hebben de opdracht uitgevoerd zoals bedoeld, één student heeft eerst videobeelden gemaakt en daarna de theorie bestudeerd en één student heeft de theoretische verdieping achterwege gelaten.

Op één na werken de studenten in zelfgekozen vaste samenwerkingsverbanden. Zij zijn allen tevreden over deze samenwerking. Vijf studenten noemen positieve effecten van de samenwerking, één vindt het weliswaar leuk en in dit geval praktisch, maar ziet geen meerwaarde.

\section{Uitwerking}

Studenten verschillen zeer in hun aanpak van de conceptuele verdieping en het maken van de videobeelden. Vier studenten hebben de opdracht uitgevoerd volgens opzet. In één geval (Sas, deeltijdstudent) zijn daarbij taken in haar groep verdeeld naar voorkeuren: theorie en creativiteit. Toch vindt ze dat iedereen zich de theorie eigen heeft gemaakt door discussie en overleg. '(...) Er zaten ontzettend veel overlegmomenten in: Hoe zou jij daar tegen aan kijken, overleg dat met elkaar. Dus dan spreek je toch die hele opdracht weer door'. Sas, Wendy en Leanne geven aan alle onderdelen van de opdracht serieus te hebben gedaan, de literatuur te hebben doorgenomen; zij noemen hiervoor verscheidene redenen: interesse in het onderwerp, willen weten hoe je een bepaalde situatie professioneel aanpakt, bereidwilligheid om te leren van theorie. Nick daarentegen heeft de conceptuele verdieping snel gedaan en zich vooral geconcentreerd op het filmen, omdat hij dat een leuk onderdeel vond.

Eén student heeft de volgorde in de opdrachtonderdelen veranderd en eerst videobeelden gemaakt en daarna de conceptuele verdieping gedaan, uit enthousiasme voor het onderwerp en het filmen. Dat vond Nicole achteraf wel onhandig: 'Handiger en gemakkelijker om eerst theorie te bestuderen en dan filmpjes te maken, want je komt dan toch dingetjes te weten.' Haar groep kreeg aanvankelijk een onvoldoende en moest herkansen. Ze geeft nadrukkelijk een verbetersuggestie: 'Eerst vereisen dat studenten theorie doen en dan pas mogen ze filmen'.

Eén student, Karla, heeft de conceptuele verdieping achterwege gelaten. Enige theorie heeft ze wel verwerkt in de presentatie: 'We hebben ook die begrippen nog eventjes erin gezet. Wat is wel goed, wat is niet goed? En die beleidsdoelen, die begrippen kwamen er ook nog wel even in voor. Ja, we hebben met $z^{\prime} n$ vieren gekeken welke begrippen bij welk videofilmpje hoort en we hadden die begrippen dus uit de aantekeningen gehaald.' Karla beschrijft haar eigen aanpak als snel en 
handig, maar tegelijkertijd onbevredigend: 'Theoretische verdieping was niet nodig, want de collegeaantekeningen gaven voldoende info. Er was altijd wel iemand die zo'n begrip kon ophalen en wist wat het inhield. Ik heb geen boek gezien. Toch hoort theorie eigenlijk wel bij een opdracht'.

Het maken van de presentatie met videobeelden was motiverend en plezierig voor alle studenten, ook voor degene die zich aanvankelijk schaamde en er tegenop zag om gefilmd te worden. Daadwerkelijk iets kunnen doen in plaats van alleen theorie verwerken sluit goed aan bij de behoefte van studenten.

De tijdsinvestering voor het maken van de videobeelden ligt tussen 1 en 2 uur. Alleen de deeltijdstudent heeft enig commentaar op de tijdsinvestering. Zij heeft 1 à 2 vrije avonden op de hogeschool nodig die moeilijk beschikbaar zijn. Niet alle studenten beschikken over de technische vaardigheden om video te bewerken, ofschoon dit een onderdeel van de opleiding is. Zij schakelen daarvoor medestudenten of externe hulp in.

Wat betreft de samenwerking: Studenten werkten op één na in zelfgekozen samenwerkingsverbanden en zijn hierover tevreden. Vijf studenten noemen diverse positieve effecten van de samenwerking:

1. Bij het rollenspel brengen anderen je in lastige situaties die je zelf niet had bedacht;

2. Anderen hebben andere ideeën en oplossingen voor hetzelfde probleem;

3. Theorie gaat sneller met tweeën;

4. Kwaliteiten zijn aanvullend: de een is goed in planning, de ander in precisie en ikzelf in de middenweg;

5. Je leert samenwerken in een team, net als op een basisschool;

6. Je leert kritiek ontvangen en geven en aanvaarden dat anderen anders communiceren;

7. Samenwerken werkt als stok achter de deur om daadwerkelijk te beginnen aan een opdracht.

Nick vindt dat vooral het theoretische onderdeel waarvoor hij zelf verantwoordelijk was, goed blijft hangen: 'Andermans onderdeel maak je je niet eigen.' Nick was afwezig bij de consultatie en geeft aan dat hij nauwelijks heeft uitgewisseld met zijn medestudenten.

\section{Interpretatie}

Nagegaan wordt wat de voorgaande resultaten betekenen voor de werkwijze die wordt verwacht in het onderwijsarrangement op het gebied van het verbinden van conceptuele kennis aan professioneel handelen en voor de samenwerking. Verwacht werden dat studenten een bepaalde volgorde in de uitvoering van de deeltaken zouden aanhouden en dat op grond van de conceptuele verdieping theorie werd geïntegreerd in de presentatie met eigen videobeelden. Op het gebied van samenwerking was de verwachting dat deze als positief zou worden ervaren. 
Sommige studenten voeren de opdracht uit zoals bedoeld, maar niet alle: een student verandert de volgorde, een student slaat de conceptuele verdieping over. De mate van verdieping in de conceptuele structuur verschilt, alsook de 'serieusheid' waarmee de communicatieve situatie wordt geanalyseerd. Ook verschilt de mate van aandacht waarmee de relatie tussen conceptuele kennis en professioneel handelen in de eigen videobeelden wordt gelegd. Sommige studenten concentreren zich op het maken van videobeelden zonder de relatie met conceptuele kennis te leggen of door dit oppervlakkig te doen. Het maken van videobeelden wordt niet als bijzonder arbeidsintensief ervaren, behalve door de deeltijdstudent.

Om studenten te stimuleren tot gewenst leergedrag waarbij de concepten diepgaand worden bestudeerd en de verbinding tussen concepten en professioneel handelen wordt gelegd, worden twee verbeteringen aangebracht.

Een student stelt voor de juiste volgorde in de uitvoering van de opdracht op te leggen: Videobeelden mogen pas worden gemaakt nadat de theorie is verwerkt in opdrachten. Dit voorkomt mogelijkerwijs dat de 'doeners' vergeten te 'denken'. Deze suggestie is niet uitvoerbaar, de docent kan dit niet verbieden of controleren, en een dergelijke vorm van sturing is bovendien niet passend bij het uitgangspunt van verantwoordelijkheid nemen voor het eigen leerproces dat wordt gehanteerd in de opleiding. Om enigszins tegemoet te komen aan de geuite behoefte aan sturing, is het wel haalbaar dat dat de docent tijdens de consultatie nadrukkelijker aandacht besteedt aan het verband tussen de conceptuele verdieping en de videobeelden.

$>$ Verbetering: Docent geeft extra aandacht aan inhoudelijk verband tussen conceptuele verdieping en videobeelden.

Sommige studenten verdiepen zich onvoldoende of niet in de theorie. Het aanscherpen van de beoordelingscriteria kan een stimulans zijn om dit wel te gaan doen. Dit schept de juiste verwachting van het vereiste niveau en bevordert daardoor mogelijkerwijs conceptuele verdieping van studenten die dit overslaan of oppervlakkig aanpakken.

> Verbetering: Concretiseren en aanscherpen van beoordelingscriteria.

Uit de resultaten met betrekking tot samenwerking wordt het volgende afgeleid: samenwerking leidt tot positieve leerervaringen, mits die samenwerking daadwerkelijk plaatsvindt. In één geval heeft uitwisseling van ervaringen en conceptuele verdieping nauwelijks plaatsgevonden en wordt de meerwaarde dan ook niet ervaren. Studenten hebben reeds de mogelijkheid bij onoplosbare problemen in de samenwerking de docent hulp te vragen. Een verbetering van het onderwijsarrangement volgt hieruit niet. 


\subsubsection{Presentatie en beoordeling}

Gevraagd is naar de ervaring met het presenteren en de manier van beoordeling.

\section{Samenvatting}

Drie studenten vinden het presenteren erg motiverend vanwege het vertonen van de filmpjes waarop ze trots zijn. Voor twee is het spannend om eigen beelden te vertonen. Het is belangrijk om dit in de eigen tutorgroep te kunnen doen vanwege vertrouwdheid en veiligheid. Het houden van een presentatie is motiverender dan het inleveren van een werkstuk. Studenten hebben belangstelling voor presentaties van medestudenten. Videobeelden maken presentaties interessanter, spannender en leerzamer dan normaal.

De werkwijze bij de beoordeling leidt tot enige ongelijkheid. Er is een volgordeeffect: Latere groepen profiteren van eerste groep. Alternatieven hiervoor worden niet geboden. Op het meebeoordelen door studenten wordt positief gereageerd, hoewel het lastige kanten heeft op het sociale vlak: kritiek leveren is moeilijk. De docent moet wel het laatste woord hebben en de criteria toepassen. De status van de conceptuele verdieping was niet voor iedereen duidelijk. Dit kan verbeterd worden.

\section{Uitwerking}

Studenten hebben belangstelling voor de groepspresentaties van medestudenten. Videobeelden maken presentaties interessanter, spannender dan normaal. Leerzaam is zien hoe anderen dezelfde communicatieve situatie hebben aangepakt, maar studenten noemen ook de andere situaties waarvan je leert. Op hun eigen presentatie doen ze hun best 'want je wil goed voor de dag komen'. Leanne benadrukt dat de duur van de presentatie te kort was en verlengd moet worden tot 20 minuten om bevredigend te zijn.

Op inspraak in de beoordeling wordt positief gereageerd. Studenten zitten in hetzelfde schuitje, weten precies wat anderen hebben gedaan, hebben een andere kijk dan docenten, benadrukken vooral de positieve kanten. De docent moet daarentegen het laatste woord hebben: hij is objectiever, kent de bedoeling van de opdracht, soms beheersen studenten stof niet en kunnen ze criteria dus niet toepassen.

Bovendien heeft meebeoordelen lastige kanten op het sociale vlak: Afhankelijk van zelfvertrouwen en de sfeer in de groep durven studenten wel of geen negatieve kritiek te leveren. Karla geeft expliciet aan dat je er bij negatieve kritiek 'uit ligt'. Zij levert dan ook geen negatieve kritiek, hoewel ze een slechte prestatie wel herkent. In andere groepen wordt wel negatieve kritiek geuit als de prestatie echt slecht is, ook al is dat moeilijk. De drive hiervoor is rechtvaardigheid: 'Als dit een voldoende is, hoef ik nooit meer mijn best te doen' (Wendy).

De werkwijze bij de beoordeling leidt tot enige ongelijkheid. De eerste groep heeft het 't moeilijkst, de latere groepen profiteren van de informatie en de doorvragen bij de eerdere presentaties. $\mathrm{Zij}$ kunnen daarop inspelen en er gebruik van maken. 
Hiermee is te leven, zolang de docent evident slechte prestaties gewoon een onvoldoende geeft en studenten geen ruimte geeft om 'zich eruit te kletsen'. Doorvragen van docent is wel rechtvaardig als bijvoorbeeld een onderdeel ontbreekt of niet helder is.

De status van de conceptuele verdieping was niet voor iedereen duidelijk. Sommige studenten hadden een werkstuk gemaakt. De uitwerking en vormgeving daarvan kostte veel tijd. Niet helder was dat de conceptuele verdieping slechts diende als voorbereiding op de presentatie. Dat de docent het werkstuk niet beoordeelde, leidde tot frustratie bij degenen die er werk van hadden gemaakt. Studenten stellen voor ofwel de conceptuele verdieping te beoordelen ofwel de status ervan te verhelderen.

\section{Interpretatie}

Verwacht werd dat studenten elkaars presentaties leerzaam zouden vinden en dat ze veel invloed op de beoordeling zouden willen hebben. Het eerste blijkt waar te zijn, maar het tweede niet.

Videobeelden spelen een belangrijke motiverende rol bij het presenteren en het bijwonen van presentaties van medestudenten. Om de presentatie voldoende inhoudelijk te maken, wordt voorgesteld de duur te verlengen tot 20 minuten.

$>$ Verbetering: Duur presentatie verlengen tot 20 minuten.

Inspraak in de beoordeling wordt door studenten positief gewaardeerd, maar de kwaliteit ervan is afhankelijk van de sfeer in de groep en het zelfvertrouwen en de kennis van de individuele student. Daarom blijft het belangrijk dat het oordeel van de docent doorslaggevend is. Concretere, hardere criteria kunnen de docent hierbij behulpzaam zijn.

> Verbetering: Beoordelingscriteria concretiseren.

De bedoeling en status van de conceptuele verdieping was niet voor iedereen duidelijk. Klassieke beelden van theorie en praktijk lijken hierbij een rol te spelen: in het werkstuk staat de theorie, in de presentatie staat de praktijk in de videobeelden centraal. Om te bereiken dat tijdens de presentatie de concepten worden gehanteerd als gereedschap waarmee het communicatieve gedrag kan worden onderbouwd, is het zinvol de opdrachten waarin theorie wordt verwerkt voorafgaande aan de presentatie te bespreken, bijvoorbeeld in de consultatie. Dit sluit tevens aan bij de behoefte van studenten dat hun werk erkend wordt door de docent. De algemene verbetersuggestie van studenten om de functie en status van de conceptuele verdieping te verhelderen, wordt op deze wijze geconcretiseerd.

$>$ Verbetering: Docent geeft extra aandacht aan inhoudelijk verband tussen conceptuele verdieping en videobeelden tijdens de consultatie (komt overeen met verbetering bij werkwijze). 


\subsubsection{Materialen}

Gevraagd is welke materialen zijn gebruikt en hoe ze worden gewaardeerd.

\section{Samenvatting}

De opdracht is helder en toegankelijk.

Drie studenten met de casus 'agressieve ouder' hebben de concept map niet gebruikt, omdat deze nog onvolledig was. Zij hebben de bijbehorende literatuur wel bestudeerd en de beoordelingscriteria bekeken.

Eén student heeft de concept map uitgebreid gebruikt en daarnaast collegeaantekeningen. De beoordelingscriteria heeft hij kort voor de presentatie vluchtig bekeken. Eén (deeltijd)student heeft de concept map uitgebreid gebruikt, daarnaast aanbevolen literatuur en de beoordelingscriteria. Eén student heeft uitsluitend collegeaantekeningen gebruikt.

\section{Uitwerking}

In het onderwijsarrangement wordt er vanuit gegaan dat studenten gebruik maken van de concept map en de daarin opgenomen verwijzingen naar andere bronnen. Dit gebeurt maar ten dele.

De opdracht voor de casus 'agressieve ouder' is uitgedeeld op papier, omdat de concept map in dit stadium nog onvolledig was. De noodzaak voor het raadplegen van de concept map bestond voor deze studenten dus niet. Zij hebben wel de bijbehorende literatuur bestudeerd.

Van de overige drie studenten hebben twee de concept map uitgebreid geraadpleegd. De deeltijdstudent Sas benoemt de aansluiting met een eerdere opdracht: 'Het sloot mooi aan op wat je vorig jaar had. Je kreeg dezelfde begrippen, het werd uitgebreid met nieuwe begrippen, je moest het toepassen.' Zij heeft gebruik gemaakt van de concept map en van de doorverwijzende functie naar analoge bronnen. Deze manier van werken is bedoeld in het onderwijsontwerp.

Nick heeft de concept map gebruikt als primaire bron: 'Ik heb er eigenlijk alles vandaan gehaald, naast de collegeaantekeningen.' Hij heeft geen gebruik gemaakt van de doorverwijzende functie van de concept map. Karla heeft alleen gebruik gemaakt van de collegeaantekeningen, want er was geen noodzaak om meer theorie te bestuderen.

\section{Interpretatie}

De omstandigheden maakten dat slechts drie studenten functioneel gebruik konden maken van de concept map. De deeltijdstudent heeft deze gebruikt en begrepen zoals de bedoeling was: als structuur en als doorverwijzing. Eén student, Nick, heeft de concept map gebruikt als primaire informatiebron. Eén student, Karla, heeft hem niet gebruikt (uitsluitend collegeaantekeningen). In het onderwijsontwerp wordt er vanuit gegaan dat studenten gebruik maken van de concept map en de daarin opgenomen doorverwijzingen naar andere bronnen. Dit gebeurt maar ten dele. 
$>$ Verbeteringen:

De praktische bruikbaarheid van de concept map vergroten door uitbreiding met concept 'agressie' en opname van informatielinks naar digitale bronnen.

De functie van de concept map verhelderen.

\subsubsection{Samenvatting resultaten studenten}

Het doel van dit onderdeel van de formatieve evaluatie is gedetailleerd inzicht te verwerven in de ervaringen van studenten met het onderwijsarrangement en in de verbeteringen die zij aandragen. Hun verhalen zijn tegen het licht gehouden van de bedoeling van het ontwerp; bij discrepanties zijn voorstellen voor verbeteringen geformuleerd door de onderzoeker. In Tabel 4.4 worden de belangrijkste uitkomsten kort weergegeven.

Tabel 4.4 Samenvatting van ervaringen studenten en verbeteringen van onderwijsarrangement 2 op basis van studentenevaluatie

\begin{tabular}{|c|c|c|c|}
\hline & Ervaringen studenten & $\begin{array}{l}\text { Verbeteringen } \\
\text { studenten }^{\mathrm{a}}\end{array}$ & $\begin{array}{l}\text { Verbeteringen } \\
\text { onderzoeker }\end{array}$ \\
\hline $\begin{array}{l}\text { Leeropbrengst } \\
\text { a. Motivatie voor } \\
\text { casus }\end{array}$ & $\begin{array}{l}\text { Eigen of andermans ervaring } \\
\text { met onderwerp casus; } \\
\text { Nieuwsgierigheid; } \\
\text { Toegewezen door docent. }\end{array}$ & & $\begin{array}{l}\text { Docenten- } \\
\text { handleiding } \\
\text { verbeteren: vrije } \\
\text { keuze voor casus }\end{array}$ \\
\hline b. leeropbrengst & $\begin{array}{l}\text { Uitbreiding kennis en } \\
\text { handelingsrepertoire, } \\
\text { verandering in attitude, } \\
\text { bewustwording rol } \\
\text { leerkracht; } \\
\text { Accent verschilt per student. }\end{array}$ & & \\
\hline Opzet & $\begin{array}{l}\text { Goed voorbeeld van } \\
\text { structuur met voldoende } \\
\text { vrijheid; helpt bij zwakke } \\
\text { studieplanners }\end{array}$ & $\begin{array}{l}\text { Extra, facultatieve } \\
\text { consultatie inlassen }>\end{array}$ & $\begin{array}{l}\text { Digitaal contact met } \\
\text { docent toevoegen ter } \\
\text { begeleiding }\end{array}$ \\
\hline $\begin{array}{l}\text { Werkwijze } \\
\text { a. conceptuele } \\
\text { verdieping }\end{array}$ & $\begin{array}{l}\text { Door } 5 \text { studenten gedaan, } \\
\text { door } 1 \text { niet. Verschillend in } \\
\text { aanpak en diepgang. }\end{array}$ & $\begin{array}{l}\text { Juiste volgorde eisen: } \\
\text { videobeelden mogen } \\
\text { pas gemaakt worden } \\
\text { na conceptuele } \\
\text { verdieping > }\end{array}$ & $\begin{array}{l}\text { Docent geeft extra } \\
\text { aandacht aan } \\
\text { inhoudelijk verband } \\
\text { tussen conceptuele } \\
\text { verdieping en } \\
\text { videobeelden in } \\
\text { consultatie } \\
+ \\
\text { Beoordelings-criteria } \\
\text { concretiseren en } \\
\text { aanscherpen }\end{array}$ \\
\hline
\end{tabular}


Tabel 4.4 Samenvatting van ervaringen studenten en verbeteringen van onderwijsarrangement 2 op basis van studentenevaluatie (Vervolg)

\begin{tabular}{|c|c|c|c|}
\hline & Ervaringen studenten & $\begin{array}{l}\text { Verbeteringen } \\
\text { studenten }^{\mathrm{a}}\end{array}$ & $\begin{array}{l}\text { Verbeteringen } \\
\text { onderzoeker }\end{array}$ \\
\hline $\begin{array}{l}\text { b. videobeelden } \\
\text { maken }\end{array}$ & Motiverend en functioneel. & & \\
\hline c. samenwerking & $\begin{array}{l}\text { Samenwerking leidt tot } \\
\text { toegevoegde leeropbreng- } \\
\text { sten, behalve voor } 1 \text { student }\end{array}$ & & \\
\hline $\begin{array}{l}\text { Beoordelings- } \\
\text { procedure } \\
\text { a. presenteren }\end{array}$ & $\begin{array}{l}\text { Presentaties zijn motiverend } \\
\text { vanwege videobeelden; }\end{array}$ & $\begin{array}{l}\text { Duur presentatie } \\
\text { verlengen tot } 20 \\
\text { minuten. }\end{array}$ & \\
\hline b. beoordelen & $\begin{array}{l}\text { Inspraak studenten in } \\
\text { beoordeling is goed, maar } \\
\text { docent moet doorslag- } \\
\text { gevend oordeel geven; } \\
\text { Volgorde-effect: Latere } \\
\text { groepen hebben voordeel } \\
\text { van presentatie eerste groep. }\end{array}$ & $\begin{array}{l}\text { Status conceptuele } \\
\text { verdieping } \\
\text { verhelderen }\end{array}$ & $\begin{array}{l}\begin{array}{l}\text { Beoordelings- } \\
\text { criteria concreti- } \\
\text { seren; }\end{array} \\
\text { Uitstellen van } \\
\text { beoordeling tot alle } \\
\text { groepen hebben } \\
\text { gepresenteerd. }\end{array}$ \\
\hline $\begin{array}{l}\text { Materialen } \\
\text { a. opdracht }\end{array}$ & Opdracht is helder. & & $\begin{array}{l}\text { De functie van de } \\
\text { concept map } \\
\text { verhelderen; }\end{array}$ \\
\hline $\begin{array}{l}\text { b. beoordelings- } \\
\text { formulier }\end{array}$ & $\begin{array}{l}\text { Beoordelingscriteria worden } \\
\text { door } 4 \text { studenten gebruikt. }\end{array}$ & & \\
\hline $\begin{array}{l}\text { c. bronnen/ } \\
\text { concept map }\end{array}$ & $\begin{array}{l}\text { Mate van bestudering } \\
\text { bronnen is zeer verschillend. } \\
\text { Concept map is door twee } \\
\text { studenten gebruikt: als } \\
\text { primaire informatiebron én } \\
\text { zoals bedoeld (als structuur } \\
\text { en doorverwijzend naar } \\
\text { andere bronnen). }\end{array}$ & & $\begin{array}{l}\text { De praktische } \\
\text { bruikbaarheid van } \\
\text { de concept map } \\
\text { vergroten door } \\
\text { uitbreiding (o.a. } \\
\text { met concept } \\
\text { agressie) en } \\
\text { informatielinks op } \\
\text { te nemen naar } \\
\text { digitale bronnen. }\end{array}$ \\
\hline
\end{tabular}

Noot: aCursief en met een > wordt aangegeven dat een verbetervoorstel is aangepast door de onderzoeker. 


\subsubsection{Resultaten docenten}

\subsubsection{Leeropbrengst}

Gevraagd is naar de indruk van de leeropbrengst voor studenten.

\section{Samenvatting}

De docenten formuleren leeropbrengsten op het gebied van kennis, handelingsrepertoire, attitude en bewustwording. Het begrippenkader wordt deels goed en deels minder goed begrepen en toegepast. Verder signaleren de docenten grote niveauverschillen tussen de studenten. Opmerkelijk is tenslotte het grote enthousiasme van de studenten voor het onderwijsarrangement.

\section{Uitwerking}

Volgens de docenten is het niveau van de opdrachten goed, de moeilijkheid ligt in het verbinden van concepten met eigen opvattingen en communicatief gedrag. Communicatie kent diverse dimensies en studenten leren vrij veel nieuwe begrippen. De begrippen 'communicatieve doelen, 'beleidsdoelen' en 'kenmerken van agressie' zijn vaak goed begrepen en toegepast. Minder goed begrepen werden begrippen die verbonden zijn aan de onderwijscontext, zoals 'loyaliteit, deskundigheid' en het begrip 'gespreksvaardigheden'. Studenten gebruiken deze begrippen vaak niet of (deels) verkeerd. De docenten verschillen enigszins in hun indruk van de begrippen 'referentiele, expressieve, relationele boodschap'. Twee mogelijke verklaringen worden geopperd voor het verschil in verwerking van bepaalde begrippen: in het college is door de docenten aandacht besteed aan een beperkt aantal begrippen, sommige begrippen zijn in het eerste leerjaar al aan de orde geweest en andere moeten studenten zich via zelfstudie eigen maken. Juist die laatste begrippen zijn niet of oppervlakkig verwerkt. Dat kan erop duiden dat studenten te weinig of niet aan zelfstudie doen. Een andere verklaring is dat deze begrippen abstracter zijn en daardoor moeilijker. Joe suggereert dat eventueel een extra college een oplossing voor dit probleem kan zijn.

Daarnaast signaleren de docenten grote verschillen in niveau van verwerking. Joe signaleert dat sommige studenten vooral gericht zijn op het handelen en het maken van de videobeelden, waardoor de theoretische onderbouwing weinig diepgang krijgt. Lea benoemt ook een verschil tussen studenten uit het reguliere (met havo-, mbo- en diverse achtergrond) en het versnelde opleidingstraject (met vwoachtergrond). De laatste groep verdiept zich theoretisch meer, is haar indruk. Haar indruk is dat reguliere studenten vooral gericht zijn op het handelen. Lea wijst op de interesse en motivatie van deze studenten: 'Voor ons (docenten) was heel belangrijk dat je ook de onderbouwing zag. Maar voor de studenten was ook heel belangrijk: Doe ik het goed, in de communicatie met de ouder?' Joe en Lea stellen voor dat zij tijdens de consultatiebijeenkomst meer aandacht besteden aan de conceptuele kennis en verantwoording bij de videobeelden.

Op het gebied van gespreksvaardigheden hebben studenten zeker geleerd, zo is de indruk. Joe: 'Ik had een paar hele goede voorbeelden, die heel goed een gesprek 
openden en van wie je echt kon merken dat ze aandacht hadden besteed aan zenderen luistervaardigheden. Hoe moet ik een gesprek openen en afsluiten, een stukje samenvatten, hoe kan ik de ouder er weer bij krijgen, dat vond ik wel heel erg goed.' Opvallend vonden de docenten dat studenten uit zichzelf, in spontane gesprekken, leeropbrengsten formuleren op het gebied van bewustwording: bewustzijn van het belang van voorbereiding van een gesprek, bewustzijn dat communiceren als leerkracht meer is dan 'gewoon even praten', bewustzijn van diverse aspecten die meespelen in communicatie met ouders. Ook signaleert Joe een opvallend enthousiasme bij de studenten dat hij nooit eerder heeft ervaren. Hij schrijft dit enthousiasme toe aan de opzet van de module (beknopt, duidelijk, leerzaam, volgens studenten) en de vorm van de opdracht (het maken van videobeelden). 'Dat enthousiasme vind ik wel echt héél bijzonder. Niet voor niks nemen ze de bloopers ook nog op en willen ze die graag laten zien. Er waren meerdere groepen die dat hadden, ook bij de herkansing. Dat zegt wel wat, vind ik. Het zegt niks over het leereffect, maar wel over het plezier waarmee ze ermee bezig waren'.

\section{Interpretatie}

Om het begrip en de toepassing van conceptuele kennis te verbeteren, formuleren de docenten het voornemen hun docentgedrag aan te passen: In de consultatie meer accent leggen op de rol van conceptuele kennis en de theoretische verantwoording bij de videobeelden. Dit verbetervoorstel komt voort uit ervaring met het onderwijsarrangement en leidt niet tot een wijziging van het onderwijsarrangement. De suggestie een extra college te verbinden aan het onderwijsarrangement is vanwege beperkende randvoorwaarden niet haalbaar. Wel is het wenselijk dat de docent nieuwe begrippen met betrekking tot de onderwijscontext introduceert en toelicht, zodat studenten een handvat hebben bij de verdere bestudering ervan.

> Verbetering: Toelichting geven op nieuwe concepten met betrekking tot de onderwijscontext in college.

\subsubsection{Beoordelingsprocedure}

Gevraagd is naar ervaringen met de beoordelingsprocedure en de beoordelingscriteria.

\section{Samenvatting}

De toetsvorm wordt positief gewaardeerd, de beoordelingsprocedure en beoordelingscriteria kunnen verbeterd worden.

\section{Uitwerking}

De docenten vinden de presentatie met videobeelden een goede toetsvorm en hebben gebruik gemaakt van het beoordelingsformulier met beoordelingscriteria. De beoordelingsprocedure levert wel enkele knelpunten op. Voor de studenten is er een volgorde-effect: latere groepen profiteren van de eerdere presentaties. Zij weten beter wat de bedoeling is en waarop de docent doorvraagt en passen hun presentatie daarop aan. Dit wordt soms ervaren als onrechtvaardig. De tijdslimiet was lastig te 
handhaven, want soms ontspon zich een langdurig gesprek. Het uitspreken van een beoordeling direct na de presentatie geeft de docent weinig tijd voor reflectie en beïnvloedt de sfeer in een groep bovendien.

De beoordelingscriteria zijn niet allemaal helder, met name die betrekking hebben op de onderwijscontext en gespreksvaardigheden. Dit geeft ruimte voor ongewenste onderhandeling.

Verder constateren de docenten dat de beoordeling van presentaties zeer intensief is voor docenten en veel concentratie vergt. Het zou daarom goed zijn het aantal presentaties in een sessie te beperken.

Ten slotte is Joe is nog onvoldoende bekend met algemene procedures rond toetsen en herkansingen op de hogeschool. Een deel van zijn opmerkingen geldt daarom niet specifiek voor dit onderwijsarrangement. Wel is van belang dat een herkansingsprocedure wordt geformuleerd en dat deze werkbaar is voor docenten en studenten. Diverse suggesties voor verbetering van de knelpunten zijn in overleg met elkaar gedaan.

\section{Interpretatie}

De docenten geven de volgende verbetersuggesties voor de beoordeling die allemaal aangenomen worden, omdat ze leiden tot een betere uitvoering van het onderwijsarrangement.

> Het beoordelingsformulier kan worden verbeterd op enkele praktische punten:

- Enkele beoordelingscriteria concretiseren, met name die betrekking hebben op onderwijscontext, gespreksvaardigheden en beroepsidentiteit;

- Een categorie opmerkingen toevoegen;

- Als cesuur stellen dat alle criteria voldoende worden gescoord.

> De beoordelingsprocedure kan verbeterd worden:

- Docent stelt zo nodig enkele informatieve doorvragen, maar stelt beoordeling uit totdat alle presentaties hebben plaatsgevonden. Dit heeft verscheidene voordelen: De docent kan rustig nadenken, het 'volgorde-voordeel' voor studenten wordt beperkt en de sfeer in de groep wordt niet negatief beïnvloed door het uitspreken van onvoldoendes;

- Maximaal 4 presentaties achter elkaar plannen, vanwege spanningsboog bij studenten en gevergde concentratie van docenten;

- Duur presentatie verlengen naar 20 minuten.

$>$ Beoordelingsprocedure moet gedetailleerd gecommuniceerd worden met studenten.

$>$ Herkansingsprocedure moet expliciet geformuleerd worden en zo arbeidsextensief mogelijk zijn.

\subsubsection{Materialen}

Gevraagd is naar de waardering van de materialen, met name opdracht, videocases en concept map. 


\section{Samenvatting}

De opdrachten en videocases zijn helder en motiverend, de concept map wordt verschillend gewaardeerd door de docenten vanwege hun uiteenlopende persoonlijke ict-gerichtheid. Suggesties worden zowel gedaan voor het verbeteren van de concept map als voor het gebruik ervan door studenten.

\section{Uitwerking}

De opdrachten zijn helder en motiverend. Voor enkele studenten was niet duidelijk op welke wijze ze de conceptuele verdieping moesten vormgeven. Zij maakten naast de presentatie een heel schriftelijk werkstuk wat niet de bedoeling was. De videocases zijn volgens de docenten passend in de opleidingsfase en werken als trigger. De concept map levert verschillende reacties op van de docenten.

Joe vindt de praktische bruikbaarheid van de concept map groot: overzichtelijk, handige links, informatie is altijd beschikbaar voor iedereen, docenten kunnen gemakkelijk aanpassingen doen en studenten worden op weg geholpen naar andere bronnen. Het gebruik door studenten kan volgens hem wel verbeterd worden in kwantitatieve en kwalitatieve zin. Niet alle studenten gebruiken namelijk de concept map. Sommige studenten maken geen gebruik van bronverwijzingen en beschouwen de concept map als database en enige informatiebron.

Lea geeft persoonlijk de voorkeur aan werken met een boek dat middels een inhoudsopgave een beeld geeft van de informatie en wijt dit aan haar niet-digitale werkinstelling. Lea signaleert dat studenten uit het versnelde opleidingstraject meer met de concept map werken dan reguliere studenten. Zij suggereert dat uitbreiding van de concept map met links naar videobeelden die gesprekstechnieken demonstreren mooi zou zijn.

\section{I nterpretatie}

De docenten doen verscheidene voorstellen ter verbetering van (het gebruik van) de concept map:

$>$ Uitbreiding met concept 'gesprekssoorten' (onder andere slechtnieuws- en tienminutengesprek);

$>$ Uitbreiding met links naar videobeelden die een concreet beeld geven van gesprekstechnieken;

> Docentgedrag aanpassen: studenten moeten duidelijker geïntroduceerd worden in het gebruik en de functie van de concept map.

Een laatste verbetering van de materialen wordt afgeleid uit de bevindingen van de docenten. Om ervoor te zorgen dat studenten een helder beeld hebben van de bedoeling van de conceptuele verdieping en te voorkomen dat zij onnodig een heel werkstuk maken, kan de formulering in de opdracht worden aangepast.

$>$ Formulering opdracht aanpassen. Duidelijk maken dat 'conceptuele verdieping' niet aan vormeisen van een werkstuk hoeft te voldoen; 


\subsubsection{Samenvatting resultaten docenten}

Het doel van dit onderdeel van de formatieve evaluatie is gedetailleerd inzicht te verwerven in de ervaringen van docenten met het onderwijsarrangement en in de verbeteringen die zij aandragen. De verbetervoorstellen zijn samengevat in Tabel 4.5.

Tabel 4.5 Verbeteringen van onderwijsarrangement 2 op basis van docentenevaluatie

\begin{tabular}{|c|c|c|}
\hline & Verbetering docenten ${ }^{a}$ & $\begin{array}{l}\text { Verbetering } \\
\text { onderzoeker }\end{array}$ \\
\hline Leeropbrengst & Extra college toevoegen > & $\begin{array}{l}\text { Docentenhandleiding } \\
\text { aanpassen: toelichting } \\
\text { geven op nieuwe } \\
\text { begrippen tijdens } \\
\text { college }\end{array}$ \\
\hline $\begin{array}{l}\text { Beoordelings- } \\
\text { procedure } \\
\text { a. presenteren } \\
\text { b. beoordelen }\end{array}$ & $\begin{array}{l}\text { Duur presentatie verlengen tot } 20 \text { minuten; } \\
\text { Uitstellen van beoordeling tot alle groepen } \\
\text { hebben gepresenteerd; } \\
\text { Maximaal } 4 \text { presentaties achtereen plannen; } \\
\text { Cesuur aanpassen: alle criteria voldoende; } \\
\text { Beoordelingsprocedure gedetailleerd } \\
\text { communiceren met studenten; } \\
\text { Herkansingsprocedure vastleggen } \\
\text { - }\end{array}$ & \\
\hline $\begin{array}{l}\text { Materialen } \\
\text { a. opdracht }\end{array}$ & & $\begin{array}{l}\text { Formulering aanpassen } \\
\text { zodat verwarring } \\
\text { omtrent vorm en status } \\
\text { van conceptuele } \\
\text { verdieping wordt } \\
\text { voorkomen. }\end{array}$ \\
\hline $\begin{array}{l}\text { b. beoordelings- } \\
\text { formulier }\end{array}$ & $\begin{array}{l}\text { Beoordelingscriteria concretiseren } \\
\text { Beoordelingsformulier uitbreiden met kolom } \\
\text { opmerkingen }\end{array}$ & \\
\hline $\begin{array}{l}\text { c. bronnen/ } \\
\text { concept map }\end{array}$ & $\begin{array}{l}\text { Uitbreiden met concepten (gesprekssoorten } \\
\text { en agressie) en met links naar videobronnen } \\
\text { Docentgedrag aanpassen: studenten } \\
\text { duidelijker introduceren in functie en gebruik }\end{array}$ & \\
\hline
\end{tabular}

Noot: a Cursief en met een > wordt aangegeven dat een verbetervoorstel is aangepast door de onderzoeker. 


\subsection{Conclusie formatieve evaluatie van uitgevoerd curriculum}

De formatieve evaluatie op basis van gebruikerservaringen heeft inzicht opgeleverd in de manier waarop het onderwijsarrangement is uitgevoerd door studenten en docenten en heeft geleid tot een serie gedetailleerde verbetervoorstellen. Bij het afwegen van de verbetervoorstellen is de richtinggevende vraag steeds geweest: leidt het verbetervoorstel tot een uitvoering van het onderwijsarrangement zoals bedoeld? En past het binnen de randvoorwaarden? Op basis van de evaluatie wordt vastgesteld dat het onderwijsarrangement in hoofdlijnen wordt uitgevoerd conform de bedoeling. De bevindingen hebben naar verwachting geleid tot verbeteringen van de instrumentality van het onderwijsarrangement en geven spontaan geen aanleiding tot het signaleren van mogelijke problemen op het vlak van de congruence en cost (Doyle \& Ponder, 1977-1978). De belangrijkste conclusies worden hieronder toegelicht.

1. Het onderwijsarrangement wordt door docenten uitgevoerd zoals het is bedoeld; de mate waarin studenten het onderwijsarrangement conform de bedoeling uitvoeren is verschillend.

Docenten zijn tevreden over de praktische bruikbaarheid van het onderwijswijsarrangement en hebben het onderwijs, op een enkel detail na, uitgevoerd conform de bedoeling. De studenten hebben het onderwijsarrangement in hoofdlijnen ook uitgevoerd zoals bedoeld, maar voor een deel niet. Een student heeft de conceptuele verdieping overgeslagen en een student heeft de volgorde van de opdracht veranderd waardoor er te weinig verband ontstond tussen conceptuele verdieping en het eigen handelen in de videobeelden.

De mate waarin studenten zich verdiepen in conceptuele kennis is ook verschillend. Sommige studenten zijn vooral gericht op het uitvoerende gedeelte van de taak waarin videobeelden worden gemaakt, andere studenten bestuderen de theorie serieus en verbinden deze aan hun eigen handelen.

2. Belangrijke verbeteringen van het onderwijsarrangement hangen met elkaar samen en hebben gezamenlijk betrekking op het verwerven en toepassen van conceptuele kennis door studenten.

De verbeteringen voor het verwerven en toepassen van conceptuele kennis betreffen het docentgedrag, de concept map en de begeleiding. Het verbeterde docentgedrag gaat steeds om het accentueren en verhelderen van conceptuele kennis: zowel bij de introductie als bij de begeleiding en beoordeling van de leertaak. Docenten zien zelf kansen om hun handelen te verbeteren, waardoor de leeropbrengst voor studenten op het gebied van conceptuele kennis vergroot kan worden. Ook het vergroten van de bruikbaarheid van de concept map kan bijdragen aan een grotere leeropbrengst voor studenten. Extra begeleiding van de leertaak tenslotte is een laatste verbeterpunt om de conceptuele kennis beter te verankeren in het leerproces van de student. 
De evaluatie heeft verbeteringen van instrumentele aard opgeleverd, maar er zijn ook enkele verbeteringen geformuleerd die voortkomen uit de opvattingen en behoeften van studenten. Zo heeft de een behoefte aan meer sturing (verbetersuggestie: stel de volgorde van leeractiviteiten verplicht); een ander wil graag dat haar inspanning meer erkend wordt door de docent (verbetersuggestie: docent beoordeelt ook de conceptuele verdiepingsopdracht) en een laatste student heeft behoefte aan meer begeleiding (verbetersuggestie: extra facultatief college). Ofschoon niet alle voorstellen direct zijn gehonoreerd, is binnen de randvoorwaarden, wel tegemoet gekomen aan de behoeften van de student. Dergelijke verbeteringen dragen bij aan het aspect congruentie van het onderwijsarrangement.

3. Diverse verbeteringen betreffen de beoordeling, de beoordelingsprocedure en enkele materialen.

Vooral voor de beoordeling, de beoordelingsprocedure en enkele materialen zijn gedetailleerde verbeteringen geformuleerd die instrumenteel van aard zijn.

In Tabel 4.6 zijn alle verbeteringen die de formatieve evaluatie heeft opgeleverd, samengevat.

\section{Tot slot}

Docenten en studenten rapporteren genuanceerde leeropbrengsten met betrekking tot de verwerving en de toepassing van conceptuele kennis. Om conceptuele kennis in verband te kunnen brengen met het eigen handelen, is het voorwaardelijk dat studenten zich de conceptuele kennis eigen maken. Over de mate waarin het onderwijsarrangement erin slaagt het beoogde leerproces op gang te brengen, bestaat nog onvoldoende duidelijkheid. Meer inzicht verkrijgen in de potentiële effectiviteit van het onderwijsarrangement is daarom een doel van de formatieve evaluatiestudie in hoofdstuk 5 . 
Tabel 4.6 Verbeteringen voor de praktische bruikbaarheid van onderwijsarrangement 2 op basis van student- en docentevaluatie

\begin{tabular}{|c|c|}
\hline & Verbeteringen \\
\hline Leeropbrengst & $\begin{array}{l}\text { Docentenhandleiding aanpassen: } \\
\text { Studenten duidelijker introduceren in functie en gebruik van concept } \\
\text { map tijdens college; } \\
\text { Toelichting geven op nieuwe begrippen tijdens college; } \\
\text { Extra aandacht geven aan verband tussen conceptuele verdieping en } \\
\text { videobeelden in begeleiding; } \\
\text { Vrije keuze voor casus. }\end{array}$ \\
\hline Opzet & Digitaal contact met docent toevoegen ter begeleiding \\
\hline $\begin{array}{l}\text { Beoordelings- } \\
\text { procedure }\end{array}$ & $\begin{array}{l}\text { Duur presentatie verlengen tot } 20 \text { minuten; } \\
\text { Uitstellen van beoordeling tot alle groepen hebben gepresenteerd; } \\
\text { Maximaal } 4 \text { presentaties achtereen plannen; } \\
\text { Cesuur aanpassen: alle criteria voldoende; } \\
\text { Beoordelingsprocedure gedetailleerd communiceren met studenten; } \\
\text { Herkansingsprocedure vastleggen. }\end{array}$ \\
\hline $\begin{array}{l}\text { Materialen } \\
\text { a. opdracht }\end{array}$ & $\begin{array}{l}\text { Formulering opdracht aanpassen zodat verwarring omtrent vorm en } \\
\text { status van conceptuele verdieping wordt voorkomen. }\end{array}$ \\
\hline $\begin{array}{l}\text { b. beoordelings- } \\
\text { formulier }\end{array}$ & $\begin{array}{l}\text { Beoordelingscriteria concretiseren; } \\
\text { Beoordelingsformulier uitbreiden met kolom opmerkingen. }\end{array}$ \\
\hline $\begin{array}{l}\text { c. bronnen/ } \\
\text { concept map }\end{array}$ & $\begin{array}{l}\text { Concept map uitbreiden met o.a. begrippen 'gesprekssoorten' en } \\
\text { 'agressie'; } \\
\text { Concept map uitbreiden met links naar digitale bronnen (o.a. video). }\end{array}$ \\
\hline
\end{tabular}




\section{HOOFDSTUK 5}

\section{Tussen bedoeling en resultaat: een evaluatie van het bereikte curriculum}

\section{Inleiding}

$\mathrm{Na}$ het onderzoeken van de mogelijkheden tot verbetering van het uitgevoerde curriculum, staat in dit hoofdstuk het bereikte curriculum centraal. De bedoeling van dit tweede deel van de formatieve evaluatie is een indicatie te verkrijgen van de werking van onderwijsarrangement $2 \mathrm{om}$, op basis van diep inzicht in het leerproces en de leerresultaten van studenten, zo mogelijk tot optimalisering van het ontwerp te komen.

In deze studie wordt ten behoeve van verbetering van het onderwijsarrangement verkend welke leerresultaten het onderwijsarrangement heeft opgebracht op het gebied van conceptuele kennis. De leerresultaten alleen geven echter een onvolledig beeld van de werking van het onderwijsarrangement. Nader ingezoemd wordt ook op de manier waarop de leerresultaten tot stand zijn gekomen; met achtergrondinformatie over het leerproces van de student wordt inzicht verworven in de daadwerkelijke uitwerking van het onderwijsarrangement en ontstaat de mogelijkheid na te gaan in hoeverre het onderwijsarrangement de potentie heeft het beoogde leerproces op gang te brengen. Mocht het beoogde leerproces onvoldoende of niet op gang komen, dan zijn aanpassingen aan het ontwerp noodzakelijk.

Het hoofdstuk begint met een beschrijving van de onderzoeksmethode in paragraaf 5.1. De resultaten van een meervoudige gevalsstudie volgen in paragraaf 5.2. In paragraaf 5.3 worden de resultaten weergegeven van een vergelijking van gevallen en het hoofdstuk eindigt in paragraaf 5.4 met conclusies waarin de betekenis van de resultaten voor het ontwerp worden besproken.

\subsection{Onderzoeksmethode}

\section{Onderzoeksvragen}

Voor het in kaart te brengen van de effectiviteit van het onderwijsarrangement is een meervoudige gevalsstudie uitgevoerd (Yin, 2009) naar de leerresultaten en naar het leerproces van de student met als doel een indicatie te verkrijgen van het potentieel van het ontwerp en verbeteringen voor het onderwijsarrangement te genereren. Twee onderzoeksvragen worden in dit kader gesteld: 
1. In hoeverre gebruiken studenten conceptuele kennis bij de toelichting op videobeelden van eigen professioneel handelen?

2. Wat is de relatie tussen de werkwijze en motivatie van de student, en zijn gebruik van conceptuele kennis?

De eerste onderzoeksvraag is gericht op het beoogde leerresultaat. Het beoogde leerresultaat bestaat eruit dat studenten een communicatieve situatie kunnen analyseren en dat zij hun eigen communicatieve vaardigheden kunnen verantwoorden met behulp van een conceptuele structuur. De mate waarin studenten conceptuele kennis betekenisvol hanteren bij een mondelinge toelichting op videobeelden van hun eigen communicatief gedrag, geeft daarom een beeld van de leerresultaten.

In de tweede onderzoeksvraag worden de werkwijze en motivatie van de student bij dit specifieke onderwijsarrangement onderzocht. Een aanname daarbij was dat een positieve houding ten opzichte van theorie en interesse in het specifieke onderwerp 'Communiceren met ouders' zouden resulteren in de beoogde leerresultaten. De achterliggende vraag is of het onderwijsarrangement leidt tot het op gang brengen van het beoogde leerproces zoals beschreven in het didactisch model in hoofdstuk 3. Dat bestaat uit vijf opeenvolgende deelprocessen: mentaal beeld opbouwen, analyseren, integreren, toepassen en expliciteren. Door diep inzicht te verwerven in de motivatie en werkwijze van de student, kunnen factoren aan 't licht komen die het op gang brengen van het beoogde leerproces bevorderen, belemmeren of verklaren. Op basis van kennis over zowel de leerresultaten als het leerproces wordt inzicht verworven in de werking van het ontwerp en worden mogelijke verbeteringen afgeleid.

\section{Dataverzameling en -procedure}

Het onderwijsarrangement is uitgevoerd door 200 tweedejaarsstudenten en twee docenten Nederlands. Voor deze formatieve evaluatie zijn twee databronnen gebruikt: video-opnamen en half-gestructureerde interviews.

Om na te gaan in hoeverre studenten conceptuele kennis gebruiken, zijn video-opnamen gemaakt van de mondelinge eindpresentaties. Tijdens de eindpresentaties tonen studenten videobeelden van een (gefingeerd) oudergesprek waarin zij zelf de rol van communicatief vaardige leerkracht vervullen aan medestudenten en geven zij met behulp van conceptuele kennis een toelichting op deze beelden. Bij de eerste toetsgelegenheid zijn alle eindpresentaties van groepen studenten op video opgenomen. Om de werkwijze en motivatie van de student in kaart te brengen zijn de interviewgegevens van studenten hergebruikt (zie hoofdstuk 4). Deze (halfgestructureerde) interviews zijn afgenomen ten dienste van het eerste deel van de formatieve evaluatie dat gericht is op de uitvoering en praktische bruikbaarheid van het onderwijsarrangement. Doel van de interviews was gedetailleerd inzicht te verkrijgen in de manier waarop studenten en docenten met het arrangement hebben gewerkt om daaruit verbeteringen voor het geheel af te leiden. De interviews bevatten informatie over de werkwijze en motivatie van studenten voor dit onderwijsarrangement. 


\section{Selectie van gevallen}

Om gedetailleerd en diep inzicht te krijgen in het leerproces van de student is een kwalitatieve onderzoeksaanpak gehanteerd. In deze gevalsstudie zijn drie withincase-analyses en een cross-case-analyse uitgevoerd (Yin, 2009). Voor de selectie van de drie gevallen, golden twee voorwaarden. De eerste voorwaarde is volledigheid van de dataset. Een volledige dataset bestaat uit:

- een interview met de student

- een video-opname van de mondelinge eindpresentatie

- het digitale eindproduct: PowerPointpresentatie, inclusief videobeelden.

De selectie van participanten is met name beperkt door het aantal van zes geïnterviewde studenten (zie hoofdstuk 4). Ook de opslag van digitale eindproducten van studenten op de hogeschool bleek echter beperkingen te kennen.

De tweede voorwaarde voor selectie van de gevallen is informatierijkdom. Informatierijkdom ontstaat als een student in het interview veel gegevens verstrekt over werkwijze en motivatie.

$\mathrm{Na}$ het selecteren van de eerste casus met behulp van bovenstaande criteria zijn de twee volgende cases als volgt geselecteerd: ze bieden andere, nieuwe informatie op het gebied van werkwijze en motivatie in vergelijking met de eerste casus, zodat een genuanceerder en breder beeld ontstaat. Ook is gezorgd voor spreiding van de onderwerpen: de studenten kunnen kiezen uit drie videocases die elk een eigen opdracht kennen. Gezien deze variatie is het zinvol elk van de onderwerpen vertegenwoordigd te laten zijn in de analyse.

\section{Dataverwerking en data-analyse}

Als eerste stap zijn de video-opnamen van de drie eindpresentaties geanalyseerd op leerresultaten. Onder leerresultaten wordt het expliciete gebruik van conceptuele kennis verstaan bij de toelichting op de eigen videobeelden. Als analysekader diende een lijst van concepten die deel uitmaakten van de beoordelingscriteria. In kaart gebracht is of concepten genoemd worden en in hoeverre concepten adequaat worden toegepast op de videobeelden. Tevens is genoteerd welke concepten onverwacht werden gebruikt; daarbij gaat het om concepten die niet waren opgenomen in de beoordelingscriteria. Ook zijn researcher's notes gemaakt. Het gebruik van concepten is weergegeven in drie categorieën:

- Het concept is expliciet genoemd;

- Het concept is juist geconcretiseerd, dat wil zeggen juist begrepen en gerelateerd aan het handelen in de videobeelden;

- Het concept is onjuist geconcretiseerd, dat wil zeggen verkeerd begrepen of onjuist gerelateerd aan het handelen in de videobeelden.

De researcher's notes zijn verwerkt onder de noemer commentaar. Dit commentaar bevat een algemene indruk van de presentatie en soms specifieke opmerkingen over het gebruik van concepten. Voor het beantwoorden van de tweede onderzoeksvraag is als tweede stap informatie geselecteerd uit de interviews over de werkwijze en motivatie van de student. De werkwijze wordt opgevat als de manier waarop de student de leertaken in het onderwijsarrangement aanpakt en de motivatie wordt 
opgevat als de beweegredenen en drijfveren van de student voor het onderwijsarrangement. De studenten geven ter vergelijking ook vaak informatie over hun werkwijze en motivatie voor de opleiding in het algemeen. De informatie is verwerkt in een 'portret' van de student waarmee een gedetailleerd beeld ontstaat van hoe deze student zijn eigen werkwijze in en motivatie voor het onderwijsarrangement beschrijft. Bij de derde stap is het portret gecombineerd met de analyse van de leerresultaten in een interpretatief proces. Deze combinatie van gegevens levert mogelijke verklaringen op voor de bereikte leerresultaten en inzicht in het verband tussen de werkwijze en motivatie van de student en de bereikte leerresultaten. Op basis van de bevindingen zijn onderbouwde verbeteringen voor het onderwijsarrangement geformuleerd. Deze verbeteringen zijn tot stand gekomen door de bevindingen te vergelijken met de bedoeling van het onderwijsarrangement. De leidende vraag daarbij is: welke verbetering leidt tot het bevorderen van de beoogde leerresultaten en het beoogde leerproces?

Iedere gevalsbeschrijving bestaat uit drie onderdelen:

- samenvatting van analyse leerresultaten

- portret van de student: beeld van werkwijze en motivatie

- interpretatie: combinatie van leerresultaten en portret, inclusief verbeteringen voor het onderwijsarrangement.

Tenslotte zijn in een cross-case-analyse vergelijkingen getrokken tussen de gevallen en is gezocht naar betekenisvolle patronen. Bij deze vergelijking vormen de beide onderzoeksvragen de focus. Betekenisvolle patronen zijn gezocht met betrekking tot (a) het gebruik van conceptuele kennis en (b) de relatie tussen werkwijze, motivatie en leerresultaten. Aangezien het een eerste exploratie betreft van de leerresultaten is in dit stadium afgezien van het bepalen van interbeoordelaarsbetrouwbaarheid. In de verslaglegging worden de drie geselecteerde gevallen aangeduid als Nick, Sas en Leanne.

\subsection{Resultaten}

\subsubsection{Gevalsbeschrijving 1, Nick}

\section{Samenvatting van leerresultaten}

Van de vier concepten waarop wordt beoordeeld, wordt er één genoemd en juist geconcretiseerd: het beleidsdoel. 'Gespreksvaardigheden' worden niet genoemd, maar enkele worden wel juist geconcretiseerd. Twee concepten ontbreken. Daarnaast noemt en concretiseert Nick twee andere, relevante concepten uit het communicatiemodel: de referentiële en appellerende boodschap. De laatste is onjuist geconcretiseerd en wordt inhoudelijk verward met relationele boodschap.

Algemeen commentaar: In de presentatie wordt nadruk gelegd op het creëren van een positieve sfeer en het instandhouden van de relatie met de ouder, vanwege het beleidsdoel van de school. De meeste aandacht gaat uit naar de videobeelden. Opmerkingen getuigen van inzicht in de communicatieve situatie. 
Tabel 5.1 Samenvatting van leerresultaten Nick

\begin{tabular}{|c|c|c|c|c|}
\hline & $\begin{array}{l}\text { Concept } \\
\text { noemen }\end{array}$ & $\begin{array}{l}\text { Concept juist } \\
\text { concretiseren }\end{array}$ & $\begin{array}{l}\text { Concept } \\
\text { onjuist } \\
\text { concretiseren }\end{array}$ & Commentaar \\
\hline Beleidsdoel & Ja & $\begin{array}{l}\text { Ja } \\
\text { 'Binnen de school een } \\
\text { positieve sfeer creëren } \\
\text { door open te staan voor } \\
\text { enthousiasme van } \\
\text { ouders en opvoeders en } \\
\text { deze respecteren en } \\
\text { waarderen' }\end{array}$ & & $\begin{array}{l}\text { Dit begrip } \\
\text { wordt } \\
\text { herhaaldelijk } \\
\text { genoemd }\end{array}$ \\
\hline $\begin{array}{l}\text { Communicatief doel } \\
\text { informatief, persuasief, } \\
\text { motiverend, } \\
\text { instruerend, affectief }\end{array}$ & Nee & - & - & \\
\hline $\begin{array}{l}\text { Onderwijscontext } \\
\text { loyaliteit, } \\
\text { deskundigheid, } \\
\text { verantwoordelijkheid, } \\
\text { ouderbetrokkenheid, } \\
\text { positie stagiaire, } \\
\text { communicatiebeleid }\end{array}$ & Nee & - & - & \\
\hline $\begin{array}{l}\text { Gespreksvaardigheden } \\
\text { zender- en luister- } \\
\text { vaardigheden }\end{array}$ & Nee & $\begin{array}{l}\text { Deels } \\
\text { 'Ouder ruimte geven' } \\
\text { 'Informatie vragen' } \\
\text { 'Fysiek afwenden' }\end{array}$ & \begin{tabular}{|l|} 
Deels \\
'Fout op \\
zichzelf \\
betrekken'
\end{tabular} & $\begin{array}{l}\text { Enkele } \\
\text { gesprekstech- } \\
\text { nieken en hun } \\
\text { effect op de } \\
\text { sfeer worden } \\
\text { beschreven. }\end{array}$ \\
\hline \multicolumn{5}{|l|}{ Toegevoegde concepten } \\
\hline Referentiële boodschap & $\mathrm{Ja}$ & Ja & & \\
\hline $\begin{array}{l}\text { Appellerende } \\
\text { boodschap }\end{array}$ & $\mathrm{Ja}$ & & Onjuist & \\
\hline
\end{tabular}

\section{Portret van Nick}

In het interview geeft Nick blijk van zijn werkwijze en motivatie. Uit de interviewgegevens blijkt Nick de opdracht volgens de opzet te hebben uitgevoerd, maar het accent vooral te leggen op het filmen. Videobeelden maken heeft hem zeer gemotiveerd. 'Als ik iets doe, beklijft dat het beste'. Van de theorie is in zijn eigen woorden 'weinig blijven hangen'. Hij heeft hieraan weinig aandacht besteed en als enige bronnen de concept map en zijn collegeaantekeningen geraadpleegd.

Over het niveau van de opleiding in zijn geheel uit Nick zich ambigu. Enerzijds vindt hij de opleiding niet moeilijk en zou hij meer uitdaging op zijn plaats vinden. Theorietoetsen haalt hij gemakkelijk en dit geldt voor de meeste studenten niet. Zijn zelfbeeld is positief op dit gebied: 'Misschien ben ik wel te intelligent. Ik snap niet dat anderen het niet halen'. Anderzijds moet hij voor een ander type toetsen 
(werkstukken) meer moeite doen. Over het niveau van de communicatieopdracht weifelt Nick. De praktijkgerichtheid vindt hij goed en het oefenen vindt hij zinvol, maar meer theorie was misschien op zijn plaats geweest.

In het algemeen kost het Nick grote moeite zich aan te zetten tot het bestuderen van theorie. Als hij is geïnteresseerd in bepaalde onderwerpen, verdiept hij zich graag, maar zodra deze intrinsieke motivatie minder is, haakt hij af. Ook het niveau en de toegankelijkheid van de literatuur speelt hem parten. Hij geeft hiervan voorbeelden: Als hij een boek toegankelijk en interessant vindt (geschiedenis), leest hij het uit. Maar zodra de literatuur enigszins lastig wordt of hem niet boeit (natuuronderwijs), legt hij het weg. Bij de opdracht voor communicatie was Nick enthousiast voor het maken van videobeelden, de inhoud was voor hem van ondergeschikt belang, hoewel hij het onderwerp communicatie met ouders wel relevant vond. Nick betwijfelt of je over communicatie iets kunt leren, want 'een beetje sociaal omgaan met elkaar en respect betonen komt vanuit jezelf en niet uit een boekje'. Ook zal het 'in het echt' misschien anders gaan. Toch vindt hij dat theorie wel iets toevoegt, noemt hij enkele begrippen uit de conceptuele structuur en wijst hij erop dat nadenken over een dilemma en oefenen zinvol is.

Van extrinsieke motivatie voor het bestuderen van theorie is weinig sprake. Nick is gedemotiveerd geraakt voor het bestuderen van theorie, omdat de toetsen weinig van hem vergen. Hij beschrijft een vroege ervaring in de opleiding met toetsing: 'Geschiedenis vind ik dan wel leuk, dus ik dat hele boek doorlezen en dan krijg je drie vragen in de toets. Als je daar iets over zegt, krijg je natuurlijk commentaar van 'Je leest het voor jezelf'. Dat is ook wel zo. Maar het is wel leuk, als je zo'n heel boek hebt gelezen, dat je wat meer vragen over zo'n boek krijgt.' Naar aanleiding van deze ervaring is Nick voor het bestuderen van theorie in volgende toetsen minder gemotiveerd geraakt. 'Ik dacht: Ik krijg er toch geen vragen over en dat was ook zo.' Nick heeft tijdens zijn opleiding de ervaring opgedaan dat het mogelijk is voor toetsen een voldoende te behalen zonder dat hij daarvoor veel hoeft te leren. Hierop heeft hij zijn leergedrag aangepast: niet nodig, dan niet doen. Dit leergedrag heeft hij ook getoond bij het uitvoeren van de opdracht voor communicatie. Zijn werkwijze heeft ook in dit geval geleid tot een voldoende beoordeling.

\section{I nterpretatie}

De werkwijze van Nick is in het algemeen én bij dit onderwijsarrangement te typeren als handig en oppervlakkig, gericht op handelen. In het onderwijsarrangement heeft hij zich gericht op het maken van de videobeelden, waarin tevens zijn belangrijkste motivatie ligt voor het onderwijsarrangement. Het onderwerp communiceren met ouders wordt door hem relevant geacht. Voor conceptuele verdieping is hij om twee redenen weinig gemotiveerd: ervaring heeft hem geleerd dat deze verdieping niet nodig is voor het behalen van een voldoende en hij is de opvatting toegedaan dat communicatie niet leerbaar is.

Nicks werkwijze leidt tot beperkte leerresultaten. De analyse van leerresultaten wijst uit dat concepten strikt genomen nauwelijks worden beheerst: één concept is genoemd en juist geconcretiseerd. Ofschoon drie andere concepten worden genoemd 
en/of geconcretiseerd, ontbreken daarin conceptuele helderheid en een betekenisvolle relatie met de videobeelden.

Het beperkte gebruik van bronnen bij de conceptuele verdieping kan een deel van de leerresultaten verklaren, namelijk het toevoegen van twee concepten uit het communicatiemodel waarop zijn presentatie niet werd beoordeeld. In het college zijn die concepten uitgelegd en zo konden ze gemakkelijk (maar deels onjuist) vanuit de collegeaantekeningen worden geïntegreerd in de presentatie. De concepten waarvoor zelfstandig literatuur moest worden bestudeerd, zijn niet genoemd of op een common sense-niveau geïnterpreteerd (zoals het begrip gespreksvaardigheden).

Overigens wordt in eerste instantie tijdens de presentatie de indruk van een zekere beheersing wel gewekt. Een mogelijke verklaring voor deze indruk is dat op een common-sense-niveau wel verstandig wordt gesproken over de communicatieve situatie. Door deze common sense, het hanteren én het herhalen van enkele concepten wordt de indruk gewekt van inzicht en de beheersing van een professioneel discours. De beoordeling van de presentatie door de docent is hierdoor mogelijk beïnvloed. Hoewel uit de analyse van de leerresultaten blijkt dat zijn beheersing van concepten zeer beperkt is, is de presentatie beoordeeld met een voldoende.

De bevindingen tonen aan dat een oppervlakkige werkwijze met het accent op het maken van videobeelden, mogelijk is in het onderwijsarrangement. Om onwenselijk, oppervlakkig leergedrag zoveel mogelijk te voorkomen, kunnen twee maatregelen worden genomen:

- Beoordelingscriteria presentatie verscherpen;

- Bij tussentijdse consultatie hogere eisen stellen aan de conceptuele verdieping.

\subsubsection{Gevalsbeschrijving 2, Sas}

\section{Samenvatting leerresultaten Sas}

De vier concepten waarop wordt beoordeeld, worden allemaal genoemd. Twee zijn helemaal juist geconcretiseerd, en twee zijn niet verbonden aan het eigen handelen. Hieronder volgt een precisering:

De 'onderwijscontext' wordt uitgebreid toegelicht met relevante overwegingen, ofschoon niet alle begrippen helder onderscheiden worden. De 'gespreksvaardigheden' worden na doorvragen van de docent geconcretiseerd en enkele gespreksvaardigheden worden beschreven.

Twee concepten uit het communicatiemodel, het communicatieve en beleidsdoel, zijn toegevoegd. Deze worden niet geconcretiseerd.

Algemeen commentaar: In de presentatie wordt benadrukt dat de samenwerking verschillen en overeenkomsten tussen de groepsleden aan 't licht bracht met betrekking tot de juiste aanpak van het communicatieve probleem. De presentatie getuigt van volwassen inzicht in de communicatieve situatie en van bewustzijn van de onderwijscontext. 
Tabel 5.2 Samenvatting van leerresultaten Sas

\begin{tabular}{|c|c|c|c|c|}
\hline & $\begin{array}{l}\text { Concept } \\
\text { noemen }\end{array}$ & $\begin{array}{l}\text { Concept juist } \\
\text { concretiseren }\end{array}$ & $\begin{array}{l}\text { Concept } \\
\text { onjuist } \\
\text { concretiseren }\end{array}$ & Commentaar \\
\hline Expressieve boodschap & Ja & Deels & Deels & $\begin{array}{l}\text { Begrip juist } \\
\text { geplaatst in } \\
\text { context van } \\
\text { communicatie- } \\
\text { model. Niet } \\
\text { verbonden aan } \\
\text { eigen handelen. }\end{array}$ \\
\hline Relationele boodschap & Ja & \begin{tabular}{|l} 
Deels \\
'Altijd open staan voor \\
de ouder, bereid zijn tot \\
gesprek, meedenken, \\
oplossingen zoeken, \\
serieus nemen, willen \\
helpen'
\end{tabular} & $\begin{array}{l}\text { Deels } \\
\text { Onderscheid } \\
\text { met } \\
\text { expressieve } \\
\text { boodschap } \\
\text { wordt niet } \\
\text { gemaakt. }\end{array}$ & $\begin{array}{l}\text { Begrip juist } \\
\text { geplaatst in } \\
\text { context van } \\
\text { communicatie- } \\
\text { model. Niet } \\
\text { verbonden aan } \\
\text { eigen handelen. }\end{array}$ \\
\hline $\begin{array}{l}\text { Onderwijscontext } \\
\text { loyaliteit, } \\
\text { deskundigheid, } \\
\text { verantwoordelijkheid, } \\
\text { ouderbetrokkenheid, } \\
\text { positie stagiaire, } \\
\text { communicatiebeleid }\end{array}$ & Ja & $\begin{array}{l}\text { Ja } \\
\text { 'organisatiecultuur } \\
\text { positie stagiaire } \\
\text { inschatting urgentie } \\
\text { probleem, } \\
\text { prioriteiten stellen } \\
\text { deskundigheid } \\
\text { verantwoordelijkheid' } \\
\end{array}$ & & $\begin{array}{l}\text { Begrip wordt } \\
\text { uitgebreid } \\
\text { toegelicht. } \\
\text { Aspecten } \\
\text { worden niet } \\
\text { heel helder } \\
\text { onderscheiden. }\end{array}$ \\
\hline $\begin{array}{l}\text { Gespreksvaardigheden } \\
\text { zender- en luister- } \\
\text { vaardigheden }\end{array}$ & Ja & $\begin{array}{l}\text { Ja } \\
\text { 'Houding aanpassen' } \\
\text { 'Op gelijke hoogte } \\
\text { zitten' } \\
\text { 'Oogcontact maken' } \\
\text { 'Afspraken maken' }\end{array}$ & & $\begin{array}{l}\text { Gespreksvaar- } \\
\text { digheden } \\
\text { worden } \\
\text { geconcretiseerd } \\
\text { na doorvragen } \\
\text { docent. } \\
\end{array}$ \\
\hline \multicolumn{5}{|l|}{ Toegevoegde concepten } \\
\hline $\begin{array}{l}\text { Communicatief doel } \\
\text { Informatief, affectief, } \\
\text { persuasief, motiverend }\end{array}$ & Ja & - & - & \\
\hline Beleidsdoel & Ja & - & - & \\
\hline
\end{tabular}

\section{Portret van Sas}

In het interview gaat Sas uitgebreid in op haar werkwijze in de opdracht en haar motivatie. Ze heeft de opdracht volgens de opzet uitgevoerd en was vooral geïnteresseerd in de theorie en de uitwisseling van gedachten met haar medestudenten. Het verbeteren van haar persoonlijke communicatieve vaardigheden ervoer ze vanwege haar werkervaring als minder urgent. De opdracht vindt ze wel relevant voor deeltijdstudenten, omdat die erg verschillen in (werk)ervaring en voorkennis. Ze heeft uitgebreid gebruik gemaakt van de concept map en literatuur. 
Sas praat op een metaniveau en plaatst de opdracht in het grotere verband van opleiding en beroep: Zij benoemt de opbouw van het curriculumontwerp, legt een inhoudelijk verband met de opdracht communicatie van vorig studiejaar en bespreekt de relevantie van communicatie voor het leraarsberoep. Sas karakteriseert haar werkwijze als zelfstandig en bij voorkeur vraaggestuurd. De communicatieopdracht dwong meer tot zelfstandigheid dan menig andere opdracht en dat waardeert zij zeer. De efficiënt ingezette contacttijd en de bereikbaarheid van de docent per mail, pasten bij haar zelfsturende werkwijze.

Sas is gemotiveerd voor de gehele opleiding: ze heeft op 34-jarige leeftijd besloten tot een career change. Schriftelijke verantwoording en theoretische verdieping, vindt ze belangrijk. Ze relateert dit zelf aan haar werk: ze heeft veel met academici te maken, zorgvuldigheid en schriftelijke onderbouwing zijn in haar werk van groot belang. Deze eisen stelt ze ook aan haar opdrachten voor de opleiding. Voor de communicatieopdracht heeft Sas de aangegeven bronnen uitgebreid bestudeerd en de opdracht van vorig jaar opnieuw bekeken om haar voorkennis op te halen. Voor haar was duidelijk dat het theoretische kader werd uitgebreid met nieuwe begrippen en dat toepassing van communicatieve vaardigheden werd gevraagd. Zij heeft veel energie gestoken in de schriftelijke analyse van de videocasus waarmee ze aan de docent kon bewijzen zich verdiept te hebben in de theorie. Een ander aspect van haar motivatie ligt in een zeker vertrouwen. Sas gaat er vanuit dat de docent het beste weet wat belangrijk is en dat zij van iedere taak iets kan leren. De inhoudelijke focus van de presentatie lag voornamelijk op het communicatieve probleem zelf, de onderwijscontext en de relationele boodschap.

Sas is zeer positief over de toegevoegde waarde van coöperatief werken. $\mathrm{Zij}$ heeft veel van de opvattingen van haar medestudenten geleerd. Sas noemt de intensieve discussies (naar aanleiding van de videocasus) die ze heeft gevoerd met haar medestudenten over de dilemma's die leerkrachten tegenkomen in de beroepspraktijk. Centrale issues waren bijvoorbeeld: 'Tot hoever gaan de verantwoordelijkheid en deskundigheid van leerkrachten, wat is een professionele stijl van communiceren, hoe verschillen onze persoonlijke stijlen?'

\section{Interpretatie}

De werkwijze van Sas is in het algemeen en bij het onderwijsarrangement te typeren als zelfstandig en inhoudelijk, gericht op conceptuele verdieping. De verbetering van de eigen communicatieve vaardigheden kreeg minder aandacht, vanwege zelfvertrouwen en werkervaring met professionele communicatie. Daarnaast was Sas bijzonder gemotiveerd voor leeractiviteiten die leiden tot discussie en uitwisseling met medestudenten. Deze gedrevenheid en diepgaande interesse in de beroepspraktijk en in elkaars persoonlijke opvattingen is typerend voor deeltijdstudenten en wordt weerspiegeld in de presentatie.

Analyse van de leerresultaten laat zien dat haar werkwijze leidt tot het benoemen van zes concepten tijdens de presentatie. Twee daarvan worden adequaat en uitgebreid in verband gebracht met het eigen handelen (vooral de onderwijscontext), 
vier daarvan worden niet betekenisvol geconcretiseerd waardoor de begrippen 'los' blijven staan van het eigen handelen. Tussen verscheidene concepten wordt niet steeds een helder onderscheid gemaakt; deze blijven diffuus. Ondanks een inhoudelijke gerichte werkwijze en hoge motivatie voor de taak zijn de leerresultaten suboptimaal; Een mogelijke verklaring voor deze matige leerresultaten is de verwarring over de bedoeling van de presentatie en de schriftelijke analyse van de videocasus. De theorie is uitgewerkt in een werkstuk en in de presentatie zijn andere aspecten benadrukt. Een klassieke opvatting over toetsing lijkt mee te spelen in deze overwegingen: begrip van theorie bewijs je met een schriftelijk product.

Een andere mogelijke verklaring ligt in de complexiteit van de taak; de bevindingen laten zien dat zelfs iemand die alle kenmerken van een 'ideale' student heeft (gemotiveerd voor leren, positief gestemd ten opzichte van conceptuele kennis, zelfstandig, coöperatief werkend volgens de opdracht), niet vanzelfsprekend concepten foutloos interpreteert en relateert aan eigen handelen.

Om de leerresultaten te optimaliseren is een gerichtere aanpak van de taak wenselijk, wat kan worden bevorderd door studenten meer ondersteuning te bieden op het gebied van metacognitieve vaardigheden. Het verhelderen van de beoordelingscriteria is een maatregel die hiertoe binnen het onderwijsarrangement (en de beperkende randvoorwaarden) kan worden genomen; helder geformuleerde beoordelingscriteria geven de student richting en houvast bij het leerproces.

- Verbeteren van beoordelingscriteria

\subsubsection{Gevalsbeschrijving 3, Leanne}

\section{Samenvatting leerresultaten Leanne}

Drie concepten (van de vijf waarop wordt beoordeeld), worden expliciet genoemd en inhoudelijk juist geconcretiseerd: emotionele en instrumentele agressie, beleidsdoel en communicatief doel.

Twee concepten worden niet genoemd, maar wel juist geconcretiseerd: onderwijscontext en gespreksvaardigheden. Bij onderwijscontext worden twee aspecten op een common sense-niveau beschreven. Diverse verbale en non-verbale gespreksvaardigheden komen aan de orde. Toegevoegd zijn de concepten zender en ontvanger uit het communicatiemodel om de rollen van de gesprekspartners te beschrijven.

Algemeen commentaar: Uit de presentatie blijkt begrip van de communicatieve situatie en van de conceptuele structuur. 
Tabel 5.3 Samenvatting van leerresultaten Leanne

\begin{tabular}{|c|c|c|c|c|}
\hline & $\begin{array}{l}\text { Concept } \\
\text { noemen }\end{array}$ & $\begin{array}{l}\text { Concept juist } \\
\text { concretiseren }\end{array}$ & $\begin{array}{l}\text { Concept } \\
\text { onjuist } \\
\text { concretiseren }\end{array}$ & Commentaar \\
\hline $\begin{array}{l}\text { Emotionele en } \\
\text { instrumentele agressie }\end{array}$ & Ja & $\begin{array}{l}\text { Ja } \\
\text { ‘Reageert primair, niet } \\
\text { van tevoren beraamd.' } \\
\text { Kenmerken worden } \\
\text { genoemd. }\end{array}$ & & \\
\hline Beleidsdoel & Ja & $\begin{array}{l}\text { Ja } \\
\text { ‘Veilige sfeer voor } \\
\text { kinderen en ouders.' } \\
\text { Voorbeelden genoemd, } \\
\text { ook uit eigen ervaring. }\end{array}$ & & \\
\hline $\begin{array}{l}\text { Communicatief doel } \\
\text { informatief, persuasief, } \\
\text { motiverend, } \\
\text { instruerend, affectief }\end{array}$ & $\mathrm{Ja}$ & $\begin{array}{l}\text { Ja } \\
\text { Persuasief en affectief } \\
\text { doel worden toegelicht. }\end{array}$ & & $\begin{array}{l}\text { Verband tussen } \\
\text { beleidsdoel en } \\
\text { communicatief } \\
\text { doel wordt juist } \\
\text { verhelderd. }\end{array}$ \\
\hline $\begin{array}{l}\text { Onderwijscontext }{ }^{7} \\
\text { loyaliteit, deskundig- } \\
\text { heid, verantwoordelijk- } \\
\text { heid, ouderbetrokken- } \\
\text { heid, positie stagiaire, } \\
\text { communicatiebeleid }\end{array}$ & Nee & $\begin{array}{l}\text { Deels } \\
\text { Verantwoordelijkheid } \\
\text { en deskundigheid } \\
\text { worden enigszins } \\
\text { toegelicht. }\end{array}$ & & $\begin{array}{l}\text { Vooral op } \\
\text { common sense- } \\
\text { niveau }\end{array}$ \\
\hline $\begin{array}{l}\text { Gespreksvaardigheden } \\
\text { zender- en luister- } \\
\text { vaardigheden }\end{array}$ & Nee & $\begin{array}{l}\text { Ja } \\
\text { ‘Begroeten; Actief } \\
\text { luisteren; Ontspannen } \\
\text { houding aannemen; } \\
\text { Samenvatten; } \\
\text { Vragen stellen; } \\
\text { Oplossing bieden; } \\
\text { Positief afsluiten' }\end{array}$ & & $\begin{array}{l}\text { In het stappen- } \\
\text { plan uit de lite- } \\
\text { ratuur over } \\
\text { omgaan met } \\
\text { agressie worden } \\
\text { gespreksfasen } \\
\text { en -vaardig- } \\
\text { heden genoemd. }\end{array}$ \\
\hline \multicolumn{5}{|l|}{ Toegevoegde begrippen } \\
\hline Zender en ontvanger & $\mathrm{Ja}$ & Ja & & \\
\hline
\end{tabular}

\section{Portret van Leanne}

Leanne heeft de opdracht uitgevoerd volgens de opzet. Haar werkwijze is in het algemeen zelfsturend. Ze typeert zichzelf en de studenten met wie ze vaak samenwerkt als initiatiefrijk en doortastend. De zelfstandige werkwijze in het onderwijsarrangement sluit aan bij haar eigen werkwijze. Leanne kent echter veel medestudenten die juist behoefte hebben aan externe sturing bij (de planning en

7 Dit concept is niet bestudeerd door Leanne, maar door een medestudent in haar groep; Voor de casus 'agressieve ouder' heeft de groep schriftelijke literatuur gekregen, aangezien de concept map in dit stadium nog onvolledig was. 
inhoud van) opdrachten. Conceptuele verdieping vindt ze een vanzelfsprekend en belangrijk element van haar opleiding. Bij de communicatieopdracht noemt ze het aantonen van professioneel handelen middels videobeelden echter juist relevant, omdat 'je communicatieve vaardigheden 't beste kunt laten zien aan anderen'. In het algemeen moet het accent wat haar betreft echter niet liggen op handelen. Leanne beseft dat haar werkwijze en opvatting niet door al haar medestudenten worden gedeeld: 'Maar ik weet ook van bepaalde mensen, die denken daar heel anders over. Die denken zo makkelijk mogelijk, even snel wat filmen en we zijn er vanaf. Die hebben zich dan niet zodanig verdiept in de stof dat ze daadwerkelijk weten waar ze het over hebben'.

Leanne is in het algemeen gemotiveerd voor de opleiding. Voor het onderwijsarrangement is ze in het bijzonder gemotiveerd vanwege het onderwerp. Leanne heeft de videocasus met een 'agressieve ouder' bestudeerd. Ze heeft agressie in een gesprek nog nooit meegemaakt, maar verwacht dit in haar toekomstige beroepspraktijk wel tegen te komen. Daarom vindt Leanne het uitdagend om zich hierop voor te bereiden en wil ze weten hoe je professioneel op zoiets kunt reageren. Ze heeft veel energie gestoken in de analyse van de videocasus en de voorbereiding van haar eigen videocasus, ofschoon ze vanwege roosterplanningsproblemen slechts één week tijd had om eraan te werken. Ze heeft veel geleerd, vindt ze, omdat ze nu kennis heeft over de achtergrond van agressie en manieren om daarmee om te gaan. Zowel de theoretische verdieping als de oefening in gespreksvaardigheden vond ze zinvol. Leanne voelt zich vanwege haar toegenomen kennis en vaardigheden nu beter toegerust om dergelijke situaties in de praktijk het hoofd te bieden. Leanne heeft voor de conceptuele verdieping vooral gebruik gemaakt van de literatuur die de docent heeft uitgereikt omdat het begrip 'agressie' in de concept map nog ontbrak. Voor haar aandeel in de conceptuele verdieping had ze de concept map niet nodig.

Het blijkt belangrijk voor haar motivatie dat haar resultaten erkend worden. Leanne ervoer het als frustrerend dat de schriftelijke analyse van de videocasus als zodanig niet werd beoordeeld én dat de duur van de presentatie te kort was om alles aan bod te laten komen. Ook haar opmerkingen over de beoordeling wijzen op de behoefte aan erkenning. Ze merkt op dat een deel van haar medestudenten theorie nauwelijks bestudeert. 'Als het echt slecht is, vind ik een onvoldoende terecht, want anders hoef ik nooit meer mijn best te doen'.

\section{Interpretatie}

Leanne is in het algemeen intrinsiek gemotiveerd om te leren en hoog te presteren; zij zoekt meer naar conceptuele verdieping dan naar verbetering van haar vaardigheden. Haar werkwijze is in het algemeen en bij dit onderwijsarrangement te karakteriseren als zelfsturend en inhoudelijk, gericht op conceptuele verdieping. In dit onderwijsarrangement is zij echter ook nadrukkelijk gericht op verbetering van haar communicatieve vaardigheden vanwege onervarenheid met professionele gesprekken en handelingsverlegenheid. Deze handelingsverlegenheid motiveert haar tot 
uitbreiding en verbetering van haar communicatieve vaardigheden. Analyse van haar leerresultaten toont dat haar werkwijze goede resultaten oplevert en dat ze de meeste concepten juist hanteert en concretiseert: drie concepten worden expliciet genoemd, vier zijn juist geconcretiseerd en in verband gebracht met het eigen handelen, en éen is alleen op common sense-niveau geconcretiseerd. Dit begrip 'onderwijscontext' had, in het kader van de onderlinge taakverdeling, bestudeerd moeten worden door een groepsgenoot van Leanne door gebruik te maken van de concept map. Dat lijkt, op grond van de leerresultaten, niet gebeurd. Een mogelijke verklaring hiervoor is dat haar groepje voor de casus 'de agressieve ouder' schriftelijke literatuur kreeg van de docent, omdat de concept map nog onvolledig was; daarop heeft de groep zich geconcentreerd. Het concept wordt in de presentatie dan ook op een common senseniveau geconcretiseerd. Leannes leerresultaten benaderen de beoogde leerresultaten dicht, omdat zij de (overige) concepten betekenisvol in verband brengt met de communicatieve situatie en haar eigen handelen.

Omdat aan de concept map het concept agressie nog ontbrak, heeft Leannes groep de concept map niet bestudeerd en is het begrip onderwijscontext niet bestudeerd. Het vergroten van de praktische bruikbaarheid van de concept map is dan ook een voor de hand liggende verbetering van het onderwijsarrangement:

- Uitbreiding van de concept map met het begrip 'agressie' (en links en digitale middelen) zodat studenten altijd toegang hebben tot alle bronnen.

\subsection{Resultaten van gevalsvergelijking}

In de vorm van drie gevalsbeschrijvingen is nagegaan in hoeverre studenten conceptuele kennis hanteren om hun professioneel handelen te verantwoorden. Dit geeft een indicatie van welke concepten wel of niet worden gehanteerd en met welke diepgang. Vervolgens is in de portretten beschreven wat werkwijze, motivatie en persoonlijke leerdoelen van de student bij dit onderwijsarrangement precies behelzen. Ook is nagegaan in hoeverre werkwijze en motivatie van de student samenhangen met het leerresultaat en welke mogelijke verklaringen er voor het leerresultaat zijn. In deze cross-case-analyse wordt nagegaan welke betekenisvolle patronen gesignaleerd kunnen worden bij een vergelijking van de resultaten met betrekking tot 1) het gebruik van conceptuele kennis en 2) de relatie tussen werkwijze, motivatie en leerresultaten. In Tabel 5.4 zijn de resultaten van de gevalsbeschrijvingen kort samengevat. 
Tabel 5.4 Samenvatting resultaten gevalsbeschrijvingen

\begin{tabular}{|c|c|c|c|c|c|}
\hline & Leerresultaten & \multicolumn{3}{|l|}{ Portret } & Relatie \\
\hline & Concepten & Werkwijzeb & Motivatie $^{c}$ & $\begin{array}{l}\text { Persoonlijk } \\
\text { leerdoel }\end{array}$ & $\begin{array}{l}\text { Aanpak en } \\
\text { motivatie leiden tot }\end{array}$ \\
\hline $\begin{array}{l}\text { Geval } 1 \\
\text { Nick }\end{array}$ & $\begin{array}{l}\text { Juist } \\
\text { geconcretiseerd } \\
1(4)^{a}\end{array}$ & Video maken & $\begin{array}{l}\text { Theorie: - } \\
\text { Inhoud: } \pm\end{array}$ & - & $\begin{array}{l}\text { Nauwelijks gebruik } \\
\text { van concepten; geen } \\
\text { betekenisvolle rela- } \\
\text { tie met videocasus }\end{array}$ \\
\hline $\begin{array}{l}\text { Geval } 2 \\
\text { Sas }\end{array}$ & $\begin{array}{l}\text { Juist } \\
\text { geconcretiseerd } \\
2(4)\end{array}$ & $\begin{array}{l}\text { Verdiepen in } \\
\text { theorie } \\
\text { Discussie met } \\
\text { peers }\end{array}$ & $\begin{array}{l}\text { Theorie: + } \\
\text { Inhoud: + }\end{array}$ & $\begin{array}{l}\text { Vorming } \\
\text { beroeps- } \\
\text { identiteit }\end{array}$ & $\begin{array}{l}\text { Niet altijd juist } \\
\text { gebruik van concep- } \\
\text { ten; soms betekenis- } \\
\text { volle relatie met } \\
\text { videocasus } \\
\end{array}$ \\
\hline $\begin{array}{l}\text { Geval } 3 \\
\text { Leanne }\end{array}$ & $\begin{array}{l}\text { Juist } \\
\text { geconcretiseerd } \\
4(5)\end{array}$ & $\begin{array}{l}\text { Verdiepen in } \\
\text { theorie } \\
\text { Professioneel } \\
\text { handelen }\end{array}$ & $\begin{array}{l}\text { Theorie: }+ \\
\text { Inhoud:++ }\end{array}$ & $\begin{array}{l}\text { Opheffen } \\
\text { handelings } \\
\text { verlegen- } \\
\text { heid }\end{array}$ & $\begin{array}{l}\text { Goed gebruik van } \\
\text { concepten; } \\
\text { Vaak betekenisvolle } \\
\text { relatie met } \\
\text { videocasus }\end{array}$ \\
\hline
\end{tabular}

Noot: a Tussen () staat het totaal aantal beoordeelde concepten. bGenoemd wordt op welk onderdelen van de werkwijze de student het accent legde. ${ }^{c}-=$ niet gemotiveerd, $\pm=$ neutraal, $+=$ gemotiveerd, $++=$ zeer gemotiveerd

1. In hoeverre gebruiken studenten conceptuele kennis bij de toelichting op videobeelden van eigen professioneel handelen?

Verschillen in kwantiteit en kwaliteit

In alle drie gevallen is gebruik gemaakt van concepten in de mondelinge toelichting op videobeelden. De analyse van de leerresultaten laat echter ook een gedifferentieerd beeld zien, van zeer goed tot zwak, met betrekking tot de kwaliteit en kwantiteit van het gebruik van concepten. Niet altijd is er sprake van conceptuele helderheid: concepten worden soms deels (on)juist gehanteerd. In twee gevallen, Leanne en Sas, worden relatief veel concepten die behoren bij de leerdoelen genoemd en juist toegepast. Vooral Leanne toont een adequate toepassing van concepten op de videobeelden. Sas benoemt concepten, maar relateert deze niet altijd (adequaat) aan het eigen professioneel handelen in de eigen videobeelden. Het derde geval, Nick, toont beperkingen in benoemen én toepassen van concepten. Overigens moet de volgende kanttekening worden geplaatst: de studenten bestuderen voor een deel verschillende concepten (mede afhankelijk van de bestudeerde videocasus), wat een precieze vergelijking verhindert; de verschillende aard van de concepten beïnvloedt mogelijk het begrip ervan.

\section{Transfer}

Opvallend is dat alle drie studenten ook concepten gebruiken in de mondelinge toelichting op de videobeelden die niet direct worden getoetst en niet zijn bestudeerd in de conceptuele verdieping. Hierbij gaat het om begrippen die behoren tot het communicatiemodel dat in het voorgaande onderwijsarrangement is geïntroduceerd 
(referentiële boodschap, appellerende boodschap, communicatief doel, beleidsdoel, zender, ontvanger). Herhaling en verdieping van de conceptuele structuur in de opeenvolgende onderwijsarrangementen is een kenmerk van het curriculumontwerp. Hier lijkt sprake te zijn van een zekere mate van transfer, een gewenst effect van het curriculumontwerp.

\section{Common sense}

Verdieping van concepten vindt niet altijd plaats. Wanneer studenten bepaalde concepten niet hebben bestudeerd, worden deze genegeerd of geïnterpreteerd op basis van voorkennis en gezond verstand. Intuïtief wordt een communicatieve situatie dan wel redelijk adequaat geïnterpreteerd, maar bepaalde aspecten ontbreken in de analyse, aangezien die onbekend zijn.

Samenvattend wordt geconstateerd wordt dat het niveau waarop conceptuele kennis betekenisvol wordt verbonden aan het eigen praktisch handelen varieert van zeer goed tot zwak; verder worden enkele centrale concepten uit het begrippenkader spontaan in de analyse geïntegreerd, conform de bedoeling van het curriculumontwerp, maar vindt verdieping van concepten niet altijd plaats.

\section{Wat is de relatie tussen de werkwijze en motivatie van de student, en zijn gebruik van conceptuele kennis?}

Motivatie voor conceptuele verdieping is noodzakelijk, maar niet voldoende

De verwachting dat een positieve houding ten opzichte van conceptuele verdieping en interesse in het specifieke onderwerp 'Communiceren met ouders' zouden bijdragen aan een adequaat gebruik van conceptuele kennis, lijkt bevestigd te worden. Leanne en Sas zijn intrinsiek gemotiveerd voor conceptuele verdieping en specifiek geïnteresseerd in het onderwerp communicatie, waarvoor zij ook persoonlijke leerdoelen stellen. Leanne heeft een persoonlijk leerdoel dat voortkomt uit handelingsverlegenheid: verbetering van haar professionele vaardigheden. Sas, de deeltijdstudent, heeft als persoonlijk leerdoel de vorming van haar beroepsidentiteit door uitwisseling en discussie met medestudenten over persoonlijke opvattingen met betrekking tot communicatie. Deze twee studenten behalen zeer goede of redelijke/matige leerresultaten, omdat zij voldoende diepgang aan het leerproces weten te geven. Omgekeerd lijkt de aanname ook waar: als motivatie voor conceptuele verdieping ontbreekt, worden de beoogde leerresultaten niet behaald. Nick staat negatief tegenover conceptuele verdieping, heeft geen persoonlijke doelen op het gebied van communicatie en heeft zich in zijn werkwijze geconcentreerd op de uitvoering van een deeltaak: het maken van videobeelden. Dit heeft niet tot gewenste leerresultaten geleid, maar tot een schaars en oppervlakkig gebruik van concepten, waarbij nauwelijks betekenisvolle verbanden worden gelegd tussen concepten en eigen professionele vaardigheden.

Een werkwijze waarbij het accent ligt op conceptuele verdieping, draagt bij aan het bereiken van de beoogde leerresultaten. Motivatie voor conceptuele verdieping is daarom een noodzakelijke voorwaarde voor het bereiken van de beoogde 
leerresultaten. Interesse in het onderwerp communicatie (blijkend uit het stellen van persoonlijke leerdoelen) draagt bij aan de motivatie van studenten voor het onderwijsarrangement. Hoewel motivatie voor conceptuele verdieping noodzakelijk is om de beoogde leerresultaten te kunnen bereiken, blijkt uit de uiteenlopende kwaliteit van de leerresultaten van Leanne en Sas dat motivatie alleen niet voldoende is. Weliswaar hebben beide studenten zich gericht op conceptuele verdieping, maar de resultaten zijn verschillend. Leannes werkwijze heeft geleid tot helder gebruik van concepten en betekenisvolle verbanden tussen concepten en de eigen videocasus; de werkwijze van Sas leidt tot een deels diffuus begrip van concepten en een beperktere toepassing van concepten op het eigen handelen.

\section{Motiverend kenmerk van het onderwijsarrangement}

De motivatie van Leanne en Sas lijkt ook positief beïnvloed te worden door een kenmerk van het onderwijsarrangement zelf: de zelfsturende werkwijze. Deze werkwijze in het onderwijsarrangement sluit aan bij hun persoonlijke voorkeur.

Op basis van het voorgaande wordt vastgesteld dat de beoogde leerresultaten met behulp van het onderwijsarrangement bereikt kunnen worden, maar niet zonder meer. Het onderwijsarrangement heeft enkele kenmerken die bijdragen aan de motivatie van de student, zoals het bieden van ruimte voor het leggen van persoonlijke accenten en het stellen van persoonlijke leerdoelen; de zelfsturende werkwijze is voor sommige studenten ook extra motiverend. Voor het op gang brengen van het leerproces echter is motivatie voor conceptuele verdieping een noodzakelijke voorwaarde, want hiervoor gemotiveerde studenten weten diepgang te geven aan het leerproces. Motivatie voor conceptuele verdieping is echter geen garantie voor optimale leerresultaten: conceptuele helderheid en een betekenisvol verband leggen tussen eigen handelen en een conceptuele structuur komen niet vanzelf tot stand. Indien de motivatie voor conceptuele verdieping ontbreekt, komt het beoogde leerproces niet tot stand en worden de beoogde leerresultaten niet bereikt. Bij gebrek aan intrinsieke motivatie, ligt een mogelijkheid in het versterken van de extrinsieke motivatie door de beoordeling van eindresultaten te verscherpen.

\section{Verbeteringen van onderwijsarrangement}

Uit de gevalsbeschrijvingen en de cross-case-analyse volgen drie verbeteringen voor het onderwijsarrangement die in Tabel 5.5 zijn weergegeven. Deze verbeteringen worden ook onderbouwd door de formatieve evaluatie van de uitvoering van het onderwijsarrangement (zie hoofdstuk 4) en dragen bij aan het verhogen van de kwaliteit van het leerproces.

Tabel 5.5 Verbeteringen van onderwijsarrangement 2

\begin{tabular}{l|l} 
Leeropbrengst & $\begin{array}{l}\text { Beoordelingscriteria presentatie verscherpen } \\
\text { Hogere eisen stellen aan conceptuele verdieping bij tussentijdse consultatie }\end{array}$ \\
\hline Materialen & Uitbreiden concept map met links en digitale bronnen
\end{tabular}




\subsection{Conclusie}

De cross-case-analyse van drie gevallen levert inzicht op in de achtergronden van de bereikte leerresultaten en een versterkte onderbouwing van een aantal verbeteringen voor het onderwijsarrangement. In deze conclusie wordt eerst nagegaan wat de betekenis is van de belangrijkste bevindingen voor het onderwijsarrangement en vervolgens wat de twee formatieve evaluatiestudies van uitgevoerd en bereikt curriculum betekenen voor het ontwerp.

Deze formatieve evaluatie is gericht op het verkrijgen van inzicht in de potentiële effectiviteit van het onderwijsarrangement. Vragen daarbij zijn in hoeverre het onderwijsarrangement leidt tot de beoogde leerresultaten en in hoeverre het beoogde leerproces waarin conceptuele kennis wordt verbonden aan professioneel handelen tot stand wordt gebracht.

Geconstateerd is dat het onderwijsarrangement kan leiden tot de beoogde leerresultaten en het beoogde leerproces, mits motivatie voor het aspect conceptuele verdieping aanwezig is. De leerresultaten geven ook een indicatie voor transfer, een wezenlijk aspect van cognitieve flexibiliteit. Het beoogde leerproces bestaat uit vijf deelprocessen: opbouwen van een mentaal beeld, analyseren, integreren, toepassen en expliciteren. Conceptuele verdieping vindt met name plaats tijdens het analyseren en integreren. In geval 2 en 3 wordt het gehele leerproces doorlopen en worden binnen dat proces op grond van persoonlijke leerdoelen en interesse verschillende accenten gelegd. In geval 1 wordt het beoogde leerproces niet tot stand gebracht. Gebrek aan motivatie voor conceptuele verdieping leidt tot het overslaan van de leerprocessen analyseren en integreren: er wordt onmiddellijk overgegaan naar de toepassingsfase, wat zwakke leerresultaten tot gevolg heeft. In Figuur 5.1 is een overzicht gegeven van de leerprocessen en de accenten die de verscheidene gevallen daarin hebben gelegd.

\begin{tabular}{|c|c|c|c|}
\hline $\begin{array}{l}\text { Beoogd leerproces } \\
\text { Rich media-casus }\end{array}$ & Geval 1 Nick & Geval 2 Sas & Geval 3 Leanne \\
\hline $\begin{array}{l}\text { Rich media-casus } \\
\text { Analyseren } \\
\text { Integreren }\end{array}$ & $\begin{array}{l}\text { Mentaal beeld } \\
\text { opbouwen } \\
\text { (Analyseren) } \\
\text { (Integreren) }\end{array}$ & $\begin{array}{l}\text { Mentaal beeld } \\
\text { opbouwen } \\
\text { Analyseren } \\
\text { Integreren }\end{array}$ & $\begin{array}{l}\text { Mentaal beeld } \\
\text { opbouwen } \\
\text { Analyseren } \\
\text { Integreren }\end{array}$ \\
\hline $\begin{array}{l}\text { Toepassen } \\
\text { Expliciteren }\end{array}$ & $\begin{array}{l}\text { Toepassen } \\
\text { Expliciteren }\end{array}$ & $\begin{array}{l}\text { Toepassen } \\
\text { Expliciteren }\end{array}$ & $\begin{array}{l}\text { Toepassen } \\
\text { Expliciteren }\end{array}$ \\
\hline
\end{tabular}

Noot: De leerprocessen die de meeste aandacht van de student krijgen, zijn vetgedrukt. Tussen () staan de leerprocessen die niet plaatsvinden.

Figuur 5.1 Overzicht van de accenten die worden gelegd in het leerproces 
Nuancering is op zijn plaats over de kwaliteit van het op gang gebrachte leerproces. Motivatie blijkt een noodzakelijke, maar niet voldoende voorwaarde voor het bereiken van goede leerresultaten. Duidelijk is geworden dat er een grote spreiding is in het niveau waarop conceptuele kennis wordt verbonden aan het professioneel handelen, ook wanneer het beoogde leerproces wel plaatsvindt. De mate waarin de conceptuele kennis adequaat wordt begrepen en toegepast loopt uiteen van zeer goed (geval 3) tot matig (geval 2).

\section{Betekenis van de evaluatiestudies voor het ontwerp}

De formatieve evaluatiestudies van het uitgevoerde curriculum (hoofdstuk 4) en het bereikte curriculum (hoofdstuk 5) geven een gedetailleerd beeld van de verbeteraspecten, mogelijkheden en beperkingen van het onderwijsarrangement. Tegelijkertijd geven ze aanleiding tot enkele overwegingen met betrekking tot de doelstelling van het ontwerp.

De beperkingen in de leerresultaten en de verscheidene leerprocessen geven een indicatie dat de beoogde leerresultaten niet voor alle studenten eenvoudigweg te bereiken zijn door het onderwijsarrangement uit te voeren. Het hanteren van een conceptuele structuur om (eigen) praktisch handelen in communicatieve situaties te analyseren en te onderbouwen, blijkt niet eenvoudig te realiseren. Een mogelijke verklaring hiervoor kan enerzijds liggen in het voorgaande, inleidende onderwijsarrangement waarin de basis wordt gelegd voor het verwerven van de conceptuele structuur. Het feit dat enkele centrale concepten uit de conceptuele structuur nog diffuus worden gebruikt door studenten, wijst erop dat deze basis onvoldoende is verworven en dat meer aandacht gegeven moet worden aan deze eerste fase. De formatieve evaluatie van onderwijsarrangement 1 geeft hiervoor ook aanwijzingen en ondersteunt deze aanbeveling.

Anderzijds is de complexiteit van de taak en de concepten, die kenmerkend is voor advanced learning, mogelijk debet aan de uiteenlopende leerresultaten in dit stadium van het curriculumontwerp. Volgens de CFT is het namelijk noodzakelijk dat studenten verscheidene cases analyseren om zo in meer contexten feeling te krijgen voor de betekenis van concepten. In dit geval hebben studenten nog niet de gelegenheid gehad om zich in meerdere cases te verdiepen en bevinden zij zich in het beginstadium van het advanced learning. Het curriculumontwerp voorziet in het bestuderen van meer cases in de onderwijsarrangementen 3 en 4 en in herhaling en verdieping van de conceptuele structuur; in dat licht bezien zijn de leerresultaten bemoedigend, hoewel moet blijken of onderwijsarrangement 3 en 4 inderdaad leiden tot een diepgaand leerproces en een dieper begrip van de conceptuele structuur. Echter, het lijkt niet onwaarschijnlijk dat vanwege de complexiteit van de taak en de conceptuele structuur meer ondersteuning in bepaalde gevallen noodzakelijk is om voldoende diepgang in het leerproces aan te brengen.

De formatieve evaluatiestudie werpt ook een licht op een kwestie van geheel andere aard: de kwaliteit van de beoordeling door de docent en de cultuur van toetsing. Een factor in Nicks gebrek aan motivatie voor conceptuele verdieping, is zijn ervaring 
met toetsing op de lerarenopleiding. Conceptuele verdieping wordt niet gehonoreerd en is niet noodzakelijk voor het behalen van de toetsen, zo is Nicks ervaring. Hoewel zijn leerresultaten zwak zijn, is zijn presentatie ook in dit onderwijsarrangement beoordeeld met een voldoende.

Interessant is dat de inschatting van de beoordelende docent over de leerresultaten van studenten overeenstemt met de analyse van de leerresultaten. Toch stemt het gedrag van de docent bij de beoordeling van Nick niet overeen met haar inschatting: Er wordt een voldoende gegeven voor een presentatie die niet aan de beoordelingscriteria voldoet. Waarom gebeurt dit? Enigszins speculatief wordt hier een mogelijke reden voor opgeworpen die de docenten zelf suggereren: docenten vinden het vervelend om onmiddellijk, en plein public, een negatief oordeel te geven. Dit beïnvloedt de sfeer in de groep meestal negatief. De beoordelingsprocedure in het ontwerp brengt de docenten in een lastig parket: zij moeten snel en face to face een oordeel geven. Ten tweede is het aspect van common sense genoemd in dit onderzoek: doordat communicatieve situaties intuïtief juist worden begrepen, wordt er met gezond verstand gesproken over de situaties. Dit geeft de indruk van inzicht, maar voldoet niet aan criteria voor professioneel communiceren. De docent moet bij de beoordeling dus bijzonder alert zijn, want de algehele indruk die ontstaat tijdens een presentatie is er al gauw één van 'gezond verstand.'

Hiermee rijst in breder perspectief de vraag of docenten gewend zijn kritisch op de inhoud te beoordelen of dat zij in het algemeen gezond verstand en de relatie met de student centraal stellen. Uitspraken over het niveau van toetsing in de paboopleiding kunnen niet worden gedaan; wel is Nicks ervaring een aanwijzing dat de cultuur waarin het onderwijsontwerp functioneert, niet specifiek is gericht op conceptuele kennis. 


\section{HOOFDSTUK 6}

\section{Cognitieve flexibiliteit in ontwikkeling}

\section{Inleiding}

$\mathrm{Na}$ de formatieve evaluatie in de vorige hoofdstukken, wordt in dit hoofdstuk een effectevaluatie gepresenteerd van onderwijsarrangement 2, bestaande uit twee studies. De leerresultaten in dit vroege stadium van het leerproces geven een beeld van cognitieve flexibiliteit in ontwikkeling en vormen een aanwijzing voor de kans van slagen van de gehele interventie. Het betreft leerresultaten in een tussenstadium 'op weg naar cognitieve flexibiliteit', want in onderwijsarrangement 2 maken studenten net de overgang van introductory naar advanced learning (Jones \& Spiro, 1992; Spiro et al., 1991). Zij bevinden zich in het begin van de fase van advanced learning. Daarom worden in dit stadium minder complexe leerdoelen nagestreefd op het gebied van cognitieve flexibiliteit dan in het laatste onderwijsarrangement. Typerend voor cognitieve flexibiliteit zijn drie elementen: (a) de onderbouwing van professioneel handelen in realistische situaties met behulp van een conceptuele structuur, (b) het innemen van verschillende perspectieven en (c) het rekening houden met situatiespecifieke factoren uit de context (zie hoofdstuk 3). Het accent van de leerdoelen in onderwijsarrangement 2 ligt op de eerste twee elementen, waarbij een semi-authentieke situatie centraal staat.

De eerste studie is kwantitatief van aard en richt zich op de vraag in hoeverre conceptuele kennis, voorwaardelijk voor cognitieve flexibiliteit, door studenten wordt gehanteerd bij de onderbouwing van professioneel handelen in communicatieve situaties. De tweede studie is kwalitatief van aard en gaat nader in op de kwaliteit van het gebruik van die conceptuele kennis en van het innemen van verschillende perspectieven.

Studie 1 wordt beschreven in paragraaf 6.2 tot en met 6.4 , studie 2 in paragraaf 6.5 tot en met 6.8. Beide studies hebben dezelfde opbouw, bestaande uit een beschrijving van de onderzoeksmethode, een weergave van de resultaten en de conclusies. Het geheel wordt voorafgegaan door een beschrijving van onderwijsarrangement 2 in paragraaf 6.1 en afgesloten met een conclusie en discussie in paragraaf 6.9.

\subsection{De interventie: onderwijsarrangement 2}

In hoofdstuk 3 (Ontwerp van curriculum en instructie) is beschreven hoe onderwijsarrangement 2 past in het gehele curriculumontwerp en is het instructieontwerp verhelderd met behulp van een voorbeeld uit dit 
onderwijsarrangement. In deze paragraaf wordt een concreet beeld gegeven van de gehele opzet van onderwijsarrangement 2 (zie ook paragraaf 3.2.3).

\section{Opzet}

Het onderwijsarrangement is bedoeld voor tweedejaars Pabo-studenten die onderwijsarrangement 1 al hebben doorlopen en bestaat uit achtereenvolgens een plenair college, zelfstandig werken aan een coöperatieve leertaak, consultatie met de docent en een presentatie. Studenten kiezen ter bestudering op basis van voorkeur en persoonlijk leerdoel één van de drie beschikbare videocases: Inschakelen van ouders, Ouder de klas uit en Agressieve ouder. In groepen van vier wordt gewerkt aan twee kerntaken: (a) de analyse en interpretatie van een bestaande videocasus met behulp van concepten en (b) de productie van eigen videobeelden met toelichting. Beide kerntaken worden besproken met de docent in de consultatie. De toetsing bestaat uit een beoordeling van een presentatie van de zelfgeproduceerde videobeelden aan medestudenten en een docent.

\section{De presentatie-opdracht}

De opdracht voor de presentatie van zelfgeproduceerde videobeelden bevat twee onderdelen, waarvan de eerste het belangrijkst is: een toelichting op videobeelden van goed communicatief gedrag en een reflectie op het professioneel handelen, beide met gebruikmaking van concepten. In de reflectie beschrijven studenten persoonlijke sterke en zwakke kanten in de communicatie met ouders en verwoorden zij wat zij hebben geleerd. In Figuur 6.1 is de opzet van het onderwijsarrangement weergegeven.

De opdracht en de beoordelingscriteria sturen de studenten per videocasus naar het gebruik van bepaalde concepten uit de conceptuele structuur voor het onderdeel 'toelichting op het handelen'. Alle concepten uit de conceptuele structuur zijn op alle videocases van toepassing, met uitzondering van een enkel casusspecifiek concept zoals agressie. Bij iedere casus zijn echter bepaalde concepten relevanter dan andere en daarom lenen sommige cases zich beter dan andere voor de toepassing van bepaalde concepten. Uit didactische overwegingen is per casus een keuze gemaakt voor de toepassing van een bepaalde selectie van concepten (zie Bijlage A, hoofdstuk 3). Bijlage A bevat een overzicht van alle videocases uit de interventie en de bijbehorende selectie van concepten. Bij het tweede onderdeel van de opdracht, de reflectie, kiezen studenten zelf, afhankelijk van de inhoud van de reflectie, welke concepten relevant zijn om te hanteren. 


\section{Plenair college met docent}

Toelichting op conceptuele structuur

Keuze uit 3 videocases

1) Inschakelen ouder

2) Ouder de klas uit

3) Agressieve ouder
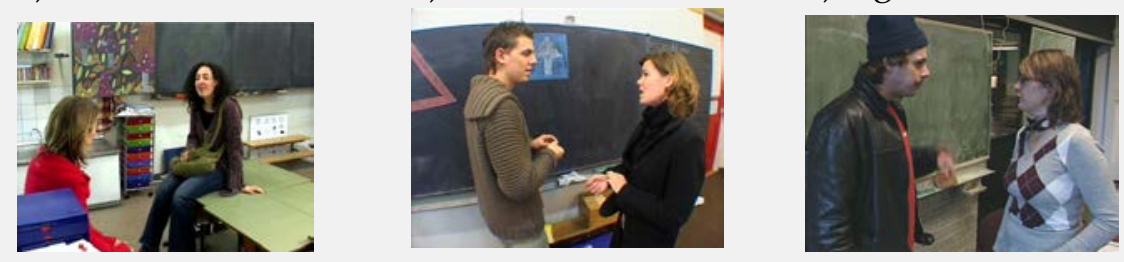

1

Zelfstandig werken aan (coöperatieve) leertaak

In groepen van vier studenten

Consultatie met docent

Bespreking van kerntaak 1: Analyse en interpretatie van bestaande videocasus

Bespreking van kerntaak 2: Productie van eigen videobeelden met toelichting

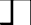

Presentatie videobeelden aan medestudenten en docent

Videobeelden van professioneel handelen studenten

Toelichting met behulp van concepten op handelen in videobeelden

Reflectie op ontwikkeling professioneel handelen: Wat geleerd?

Figuur 6.1: Opzet van onderwijsarrangement 2

\subsection{Onderzoeksmethode studie 1}

\section{Onderzoeksvragen}

In deze studie wordt nagegaan in hoeverre studenten cognitieve flexibiliteit tonen bij de mondelinge toelichting op hun professioneel handelen in videobeelden. Voor het onderzoeken daarvan is in deze eerste studie de aandacht gericht op het gebruik van de conceptuele structuur door studenten. De onderzoeksvraag luidt: In hoeverre gebruiken studenten conceptuele kennis bij de mondelinge toelichting op videobeelden van eigen professioneel handelen?

In de studie worden twee vormen van conceptgebruik onderscheiden: door de opdracht gestuurd en spontaan gebruik. Studenten worden, zoals vermeld, door de opdracht expliciet uitgenodigd bepaalde concepten te gebruiken. Daarnaast kunnen studenten concepten uit de conceptuele structuur gebruiken waarop niet is gestuurd door de opdracht; dat wordt in deze studie spontaan gebruik van concepten genoemd. Juist het spontaan gebruik van concepten duidt erop dat studenten zich de conceptuele structuur eigen beginnen te maken en dat zij cognitieve flexibiliteit ontwikkelen. Om de onderzoeksvraag te beantwoorden wordt zowel het door de 
opdracht gestuurde gebruik van concepten als het spontaan gebruik ervan in de mondelinge toelichting op de videobeelden geïnventariseerd.

In deze studie wordt een kwantitatieve benadering gehanteerd, waarbij wordt geïnventariseerd hoeveel en welke concepten uit de conceptuele structuur door studenten worden genoemd bij de mondelinge toelichting op hun professioneel handelen.

\section{Participanten}

Het onderwijsarrangement is uitgevoerd door alle voltijd tweedejaarsstudenten (124) van een lerarenopleiding in 31 groepjes samenwerkende studenten. Het onderwijsarrangement is uitgevoerd door vier docenten Nederlands. Alle docenten hebben vooraf een gezamenlijke training gekregen over de opzet en bedoeling van het arrangement waarin is kennisgemaakt met alle materialen en enkele eindproducten van studenten.

\section{Dataverzameling en procedure}

Voor het in kaart brengen van de leerresultaten zijn video-opnamen gemaakt van de presentaties van groepjes samenwerkende studenten. De video-opnamen zijn gemaakt tijdens het eerste reguliere toetsmoment voor de studenten. Deze mondelinge toetsen vinden plaats in vast klassenverband, dat wil zeggen dat de studenten elkaar kennen. De presentaties duren gemiddeld een kwartier, de duur varieert van elf tot achttien minuten.

Aan het eerste toetsmoment namen 30 van de 31 groepjes samenwerkende studenten deel. De data zijn verzameld in acht verschillende klassen waar de 30 presentaties werden gehouden. Bij twee klassen deden zich praktische problemen voor (zoals onverwachte roosterwijzigingen en disfunctionerende videoapparatuur). In totaal zijn daarom 23 presentaties opgenomen, afkomstig uit zeven verschillende klassen. Hiervan zijn twee presentaties niet betrokken in de analyse, omdat de betreffende studenten de opdracht niet hadden begrepen en in de toelichting op hun videobeelden geen concepten hanteerden. Dit levert 21 bruikbare presentaties op die als volgt zijn verdeeld over de drie videocases waaruit de studenten konden kiezen: Inschakelen van ouders (6), Ouder de klas uit (8) en Agressieve ouder (7). De opgenomen presentaties zijn opvraagbaar bij de auteur.

De presentaties van studenten bevatten videobeelden en worden ondersteund door een PowerPointpresentatie. Om alle informatie in ieder geval beschikbaar te hebben, zijn de getoonde PowerPointpresentaties en videobeelden ook als aparte bestanden verzameld. Iedere dataset bestaat dus uit een:

- video-opname van de presentatie (toelichting en reflectie)

$\checkmark$ PowerPointpresentatie

$\checkmark$ videobeelden.

Alle opnamen zijn gemaakt met één camera; om zo min mogelijk inbreuk te maken op de voor studenten toch al spanningsvolle toetssituatie en om docenten zo min mogelijk te belasten, is een kleine digitale camera op statief neergezet. 


\section{I nstrument}

Het instrument voor analyse van het gebruik van concepten bevat een opsomming van alle basisconcepten uit de conceptuele structuur, inclusief een aantal bijbehorende subconcepten. De basisconcepten zijn onderscheiden in (a) basisconcepten behorend bij het communicatiemodel en (b) overige basisconcepten. De verzameling subconcepten is niet uitputtend; bij bepaalde basisconcepten hoort een uitgebreide set van subconcepten die in de vakliteratuur wordt genoemd.

Per videocasus is aangegeven welke concepten in de opdracht en de beoordelingscriteria bevraagd worden, de zogenaamde opdrachtgestuurde concepten. Het instrument maakt inzichtelijk welke concepten per videocasus opdrachtgestuurd zijn en daarom 'verwacht' kunnen worden in de toelichting en welke concepten uit de conceptuele structuur daarnaast spontaan gehanteerd kunnen worden. Bijlage A geeft een overzicht van de opdrachtgestuurde concepten in alle vier onderwijsarrangementen; het gedeelte dat betrekking heeft op onderwijsarrangement 2 is in deze studie als instrument gebruikt.

\section{Dataverwerking en data- analyse}

Voor het inventariseren van de concepten is de volgende werkwijze gehanteerd. De videobeelden van de eenentwintig presentaties zijn in zijn geheel bekeken en aan de hand van het analyse-instrument is per presentatie genoteerd welke concepten expliciet worden genoemd in de toelichting. Ook is aangeven of deze concepten in de begeleidende PowerPointpresentatie waren opgenomen. Als een concept wel in de PowerPointdia stond, maar niet werd opgenomen in de mondelinge toelichting, is het concept niet gescoord. Bij de inventarisatie is een onderscheid gemaakt tussen opdrachtgestuurde concepten en spontaan genoemde concepten. In de videocases 'Inschakelen ouder' en 'Ouder de klas uit' worden in de opdracht vijf basisconcepten bevraagd, in de videocasus 'Agressieve ouder' zijn dat er zes, waardoor de maximale score verschilt per videocasus.

Concepten zijn de begrippen die in de conceptuele structuur zijn opgenomen en die te kenschetsen zijn als vaktaal uit de communicatiekunde en de pedagogiek/psychologie. De conceptuele structuur is opgebouwd rondom een beperkt aantal basisconcepten die vaak een aantal subconcepten in zich verenigen. Het basisconcept 'communicatief doel' bijvoorbeeld kent de vier subconcepten 'informatief doel, persuasief doel, affectief doel, motiverend doel en instructief doel'.

Als in de mondelinge toelichting het basisconcept óf een of meer van de bijbehorende subconcepten expliciet wordt genoemd, is het basisconcept gescoord. De grammaticale verschijningsvorm van een concept kan verschillen vanwege de zinsstructuur waarin het is opgenomen. Zo kan 'informatief doel' (substantief) ook geformuleerd worden als 'Ons belangrijkste doel is informeren' (infinitief). In deze verschijningsvorm is het concept ook gescoord.

Gescoord is het aantal basisconcepten dat wordt opgenomen in de mondelinge toelichting waarbij geen onderscheid wordt gemaakt tussen het gebruik van één of meer subconcepten. Hiermee wordt aangesloten bij de opdrachtformulering waarin studenten 
is gevraagd bepaalde basisconcepten op te nemen in hun toelichting. De basisconcepten betreffen feitelijk deelonderwerpen die relevant zijn in de analyse en interpretatie van een communicatieve situatie. Een opsomming van subconcepten is bewust niet opgenomen in de opdrachtformulering, aangezien het de bedoeling van de opdracht is dat studenten binnen de basisconcepten zelf relevante subconcepten selecteren.

De dataverwerking heeft plaatsgevonden in twee stappen. De eerste stap bestond uit het noteren van citaten per toelichting waarin concepten en subconcepten werden genoemd en de tweede stap bestond uit het onderbrengen van de subconcepten bij het bijbehorende basisconcept.

De analyse van het conceptgebruik in de toelichting op de videobeelden van professioneel handelen, heeft als volgt plaatsgevonden: Ten eerste is geteld hoeveel concepten per toelichting worden gehanteerd, zowel opdrachtgestuurd als spontaan. Dit geeft een getalsmatig beeld van het conceptgebruik. Ten tweede is het gebruik van de opdrachtgestuurde concepten nader geanalyseerd. Daarvoor is per opdrachtgestuurd concept geteld in hoeveel toelichtingen het is gebruikt, waarmee duidelijk wordt in welke mate de opdrachtgestuurde concepten worden gehanteerd. Ten derde zijn de spontaan genoemde concepten geanalyseerd, waarbij is nagegaan welke soort concepten spontaan zijn gehanteerd in de toelichtingen. Ten slotte is per videocasus nagegaan hoe vaak bepaalde concepten worden gehanteerd om eventueel specifieke onderwerpsgebonden invloeden op te sporen. Dat bleek niet het geval te zijn: in ieder van de drie videocases is door studenten zowel de hoogste als de laagste score behaald.

\subsection{Resultaten conceptgebruik}

In de rapportage van de resultaten worden drie aspecten van het gebruik van concepten in de toelichting op de videobeelden weergegeven. Eerst wordt weergegeven hoeveel opdrachtgestuurde concepten per toelichting worden genoemd. Daarna wordt het aantal en soort spontaan gebruikte concepten weergegeven. Ten slotte wordt weergegeven hoe vaak ieder opdrachtgestuurd concept is gehanteerd.

\section{Aantal opdrachtgestuurde concepten}

Uit de analyse van de toelichting op de videobeelden blijkt dat in 18 (van de 21) toelichtingen tenminste 4 opdrachtgestuurde concepten zijn gebruikt. Figuur 6.2 laat zien hoe het conceptgebruik is verdeeld over de 21 toelichtingen. Het gemiddeld aantal concepten per toelichting is 4,3 met een minimum van 3 en een maximum van 6 concepten. ${ }^{8}$

8 De hoogste score is niet af te leiden uit de grafiek, aangezien in veertien toelichtingen het hoogst aatal opdrachtgestuurde concepten vijf is en in zeven toelichtingen het hoogst aantal opdrachtgestuurde concepten zes is. 


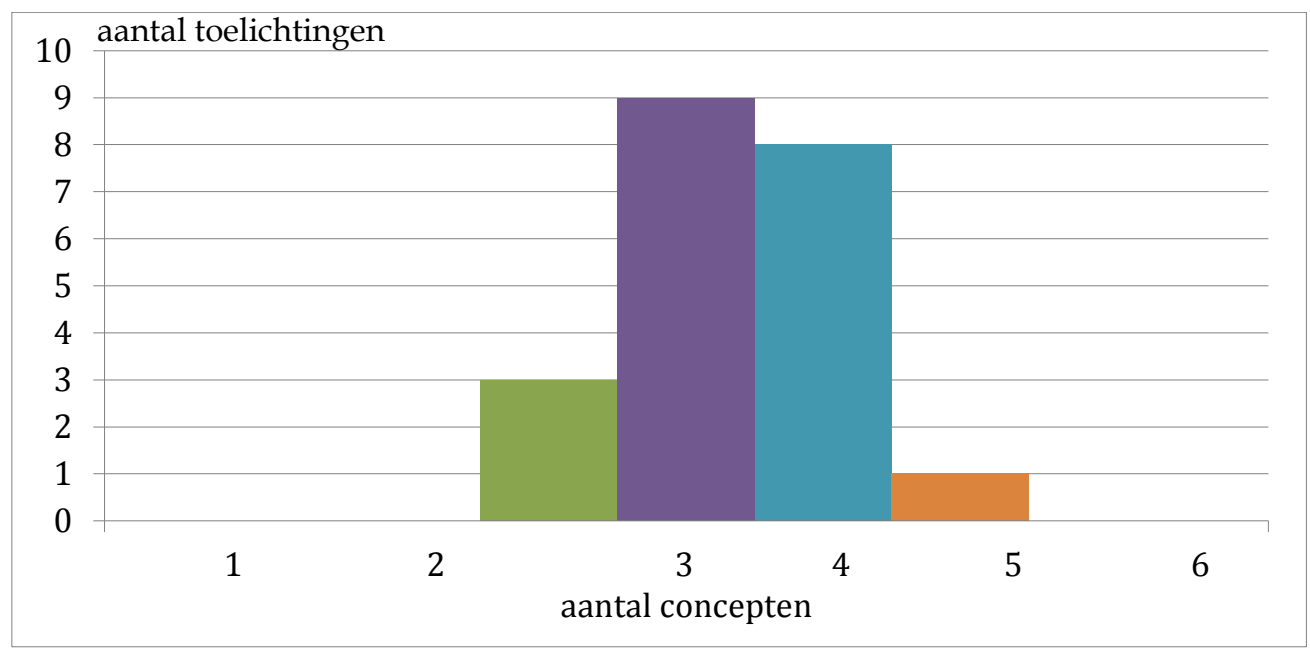

Figuur 6.2: Het aantal opdrachtgestuurde concepten

\section{Aantal en soort spontaan genoemde concepten}

In ruim tweederde van de toelichtingen (15 van 21) worden ook spontaan concepten gehanteerd. Het gemiddeld aantal spontaan gehanteerde concepten is 2,3 met een minimum van 1 en een maximum van 7 concepten.

Nagegaan is welk soort concepten spontaan zijn opgenomen in de mondelinge toelichting op de videobeelden. Bijna driekwart van deze concepten betreft concepten uit het communicatiemodel (25 van 34), waarbij 'communicatief doel' het vaakst (6) wordt genoemd. Binnen het overige kwart heeft het concept 'gespreksvaardigheden' een opvallend hoge score (7 van 9).

\section{Frequentie van opdrachtgestuurde concepten}

Tabel 6.1 laat per opdrachtgestuurd concept zien in hoeveel toelichtingen op de videobeelden het is gehanteerd. Aangezien sommige concepten in alle videocases worden bevraagd en andere casusgebonden zijn, is het maximaal aantal mogelijke scores verschillend, variërend van 21 tot 6 . De dataverzameling bestaat uit zes gevallen voor videocasus 1 , acht gevallen voor videocasus 2 en zeven gevallen voor videocasus 3 .

Zeven concepten worden in vrijwel alle toelichtingen genoemd. De concepten 'communicatief doel' en 'emotionele en instrumentele agressie' hebben beide een maximale score en worden dus in alle relevante toelichtingen genoemd. De concepten 'beleidsdoel, gespreksvaardigheden, expressieve boodschap, relationele boodschap, fasering in gesprek' hebben een maximale score minus één, dat wil zeggen dat zij in één relevante toelichting niet worden genoemd. Het concept 'onderwijscontext' wordt vaak, in ruim driekwart van de toelichtingen, genoemd. Relatief laag scoort 'soort gesprek' (2 van 6) en een opvallend lage score heeft 'communicatiebeleid/ protocollen' (1 van 7). 
Tabel 6.1 Frequentie van opdrachtgestuurde concepten in de toelichting op de videobeelden

\begin{tabular}{l|l} 
Opdrachtgestuurde concepten & Frequentie \\
\hline $\begin{array}{l}\text { Onderwijscontext } \\
\text { (loyaliteit, dynamische driehoek, ouderbetrokkenheid, positie stagiaire, } \\
\text { communicatiebeleid, verantwoordelijkheid, deskundigheid) }\end{array}$ & $16(21)$ \\
\hline Beleidsdoel & $20(21)$ \\
\hline $\begin{array}{l}\text { Communicatief doel } \\
\text { (informatief, motiverend, persuasief, affectief, instructief) }\end{array}$ & $14(14)$ \\
\hline $\begin{array}{l}\text { Gespreksvaardigheden } \\
\text { (concretiseringen van luister- en zendervaardigheden, regulerende } \\
\text { gespreksvaardigheden, non-verbale en verbale gespreksvaardigheden) }\end{array}$ & $12(13)$ \\
\hline $\begin{array}{l}\text { Soort gesprek } \\
\text { (Slecht-nieuwsgesprek, probleemverkennend, probleemoplossend } \\
\text { gesprek; informatief, persuasief, motiverend, instructief, evaluatief) }\end{array}$ & $2(6)$ \\
\hline Expressieve boodschap & $7(8)$ \\
\hline Relationele boodschap & $7(8)$ \\
\hline Fasering in gesprek & $6(7)$ \\
\hline Emotionele en instrumentele agressie & $7(7)$ \\
\hline Communicatiebeleid/protocollen & $1(7)$
\end{tabular}

Noot. Tussen haakjes staat het maximale aantal mogelijkheden genoemd.

\subsection{Conclusie}

Op basis van het voorgaande onderzoek worden enkele conclusies getrokken over het gebruik van concepten door studenten in het licht van de ontwikkeling van cognitieve flexibiliteit. Deze conclusies worden gevolgd door een samenvatting.

\section{Studenten gebruiken de conceptuele structuur.}

Het feit dat studenten concepten daadwerkelijk hanteren, betekent dat aan een belangrijke voorwaarde voor de ontwikkeling van cognitieve flexibiliteit is voldaan. Wel worden verschillen opgemerkt in de mate waarin concepten worden genoemd. In een derde van de gevallen worden alle opdrachtgestuurde concepten gebruikt, ruim de helft van de studenten mist één of twee concepten en een kleine groep mist twee of drie concepten.

2. Het grootste deel van de conceptuele structuur wordt frequent gebruikt.

Een nadere blik op de frequentie waarmee de opdrachtgestuurde concepten worden opgenomen in de toelichtingen laat precies zien in welke mate bepaalde concepten worden gehanteerd. Hierin is een duidelijke spreiding zichtbaar, dat wil zeggen dat zeven concepten vrijwel altijd worden genoemd, één vaak en twee weinig.

De hoge score van een deel van de concepten kan verklaard worden door de opbouw van het ontwerp, waarin herhaling en verdieping van basisconcepten essentiële 
elementen zijn. Vier concepten die vrijwel altijd worden genoemd, behoren tot het communicatiemodel dat de basis vormt van de conceptuele structuur. In het voorgaande, inleidende onderwijsarrangement stond het communicatiemodel met bijbehorende concepten centraal en in onderwijsarrangement 2 zijn de concepten, volgens het spiral curriculumprincipe, herhaald en toegepast op complexere situaties. Het frequente gebruik wijst op een brede bekendheid van deze concepten onder de studenten.

Een ander deel van de concepten die vrijwel altijd worden genoemd, betreft concepten met een procedureel karakter en het casusspecifieke concept agressie. Hoewel de concepten nieuw zijn voor de studenten en voor het eerst door hen worden toegepast, zijn ze vrijwel altijd opgenomen in de toelichting. Een mogelijke verklaring hiervoor ligt in het grote belang dat studenten hechten aan het verbeteren van hun communicatieve vaardigheden. De concepten met een procedureel karakter komen het meest tegemoet aan deze behoefte. Ook de aard van de opdracht, 'het toelichten van videobeelden van eigen professioneel handelen', leidt tot het gebruik van procedurele concepten. De maximale score van het casusspecifieke concept laat zich verklaren door de aard van de videocasus en de motivatie van studenten: begrip van dit concept is noodzakelijk om de videocasus zinvol te kunnen interpreteren en studenten hebben uit persoonlijke interesse dit onderwerp gekozen.

Eén concept, de onderwijscontext, wordt in driekwart van de toelichtingen opgenomen. In deze fase van het leerproces is het betrekken van de context bij de interpretatie van communicatieve situaties nieuw voor de studenten. De score kan dan ook beschouwd worden als een positieve indicatie voor de ontwikkeling van cognitieve flexibiliteit. In de volgende onderwijsarrangementen krijgt dit aspect meer nadruk.

Twee concepten ten slotte worden weinig gebruikt. Een mogelijke verklaring hiervoor ligt in het feit dat ze nieuw zijn en dat er weinig aandacht aan is besteed in de colleges.

3. Studenten zijn in staat, ook als de opdracht er niet om vraagt, concepten spontaan op te nemen in de toelichting op hun professioneel handelen.

Studenten blijken in staat, ook als de opdracht er niet expliciet op stuurt, concepten uit de conceptuele structuur spontaan op te nemen in hun toelichting op de videobeelden. Bij de spontaan genoemde concepten is eenzelfde patroon zichtbaar als bij de hoog scorende opdrachtgestuurde concepten: de meeste spontaan toegevoegde concepten behoren tot het communicatiemodel. Een mogelijke verklaring hiervoor is de opbouw van het ontwerp waarin herhaling en verdieping van concepten plaatsvindt. Daarnaast worden vooral gespreksvaardigheden spontaan genoemd. Hoewel deze concepten in dit tweede onderwijsarrangement nieuw zijn voor de studenten, kunnen de motivatie voor het verbeteren van hun communicatieve vaardigheden en de aard van de opdracht een verklaring vormen voor het spontaan gebruik van deze concepten. 


\subsection{Onderzoeksmethode studie $2 \mathrm{a}$}

\section{Onderzoeksvragen}

In deze tweede studie wordt de aandacht gericht op de kwaliteit van de cognitieve flexibiliteit die studenten tonen in onderwijsarrangement 2. In onderwijsarrangement 2 ligt het accent van de leerdoelen op de toepassing van de conceptuele structuur en op het innemen van diverse perspectieven op de communicatieve situatie. Daarom richten de onderzoeksvragen zich op deze aspecten van cognitieve flexibiliteit..

De eerste onderzoeksvraag luidt: Hoe en met welke kwaliteit hanteren studenten conceptuele kennis bij de toelichting op videobeelden van eigen professioneel handelen en bij de reflectie op hun handelen?

De tweede onderzoeksvraag luidt: Welke perspectieven op de communicatieve situatie betrekken studenten bij de toelichting op videobeelden van eigen professioneel handelen en welke uitwerking geven zij daaraan?

De studenten kregen een open geformuleerde opdracht om de communicatieve situatie vanuit verschillende perspectieven (leerkracht, ouder, school) te belichten. Voor de manier waarop die perspectieven geïntegreerd kunnen worden in de presentatie zijn geen richtlijnen gegeven. Daarom wordt niet alleen nagegaan welke perspectieven studenten betrekken in de toelichting, maar ook hoe zij dit doen.

Met behulp van deze twee onderzoeksvragen wordt in kaart gebracht op welke wijze cognitieve flexibiliteit zich in deze fase van de interventie manifesteert en wat de kwaliteit is van de cognitieve flexibiliteit die studenten tonen. De verwachting is dat studenten na het doorlopen van onderwijsarrangement 1 en 2 enerzijds de communicatieve situatie analyseren en hun professioneel handelen verantwoorden met behulp van juist geïnterpreteerde concepten. Anderzijds wordt verwacht dat studenten blijk geven van begrip voor de verschillende belanghebbenden in de communicatieve situatie.

\section{Onderzoeksopzet}

Deze studie is opgezet als een exploratieve, meervoudige gevalsstudie waarbij zowel drie sterke als drie zwakke gevallen (presentaties) worden onderzocht (Yin, 2009). Met deze opzet worden de uitersten van het spectrum waarbinnen de cognitieve flexibiliteit zich beweegt, in beeld gebracht. Eerst wordt iedere sterke presentatie geanalyseerd en vervolgens vindt een duiding plaats van alle sterke presentaties. Eenzelfde werkwijze wordt gevolgd voor de zwakke presentaties. In de duiding wordt gezocht naar overeenkomsten en verschillen tussen de presentaties op het gebied van het gebruiken van concepten en het innemen van perspectieven. Ten slotte wordt een vergelijking getrokken tussen de sterke en zwakke presentaties en wordt gezocht naar patronen, om te komen tot een beschrijving van de kwaliteit van de getoonde cognitieve flexibiliteit in onderwijsarrangement 2 . Waar een vergelijking van sterke en zwakke gevallen geen relevante informatie opleverde, is een afzonderlijke duiding van sterke en zwakke gevallen achterwege gelaten en vervangen door een duiding van de totale dataset ${ }^{9}$.

9 In deze studie worden de begrippen 'geval' en 'presentatie' als synoniemen gebruikt. 


\section{Dataverzameling en procedure}

In deze studie wordt gebruik gemaakt van dezelfde dataverzameling als in de eerste studie van dit hoofdstuk. De dataverzameling bestaat uit video-opnamen van presentaties van 21 groepjes samenwerkende studenten. De presentaties bevatten videobeelden van de studenten, een PowerPointpresentatie, en een mondelinge toelichting en reflectie op het professioneel handelen van de studenten. Voor een precieze beschrijving van de dataverzameling en de procedure, zie paragraaf 6.2.

\section{Selectie van gevallen}

Voor deze studie zijn zes presentaties geselecteerd. De eenentwintig presentaties van de dataverzameling zijn in eerste instantie globaal verdeeld in drie categorieën: sterk, gemiddeld en zwak. Deze indeling is gemaakt op basis van twee criteria: het aantal gehanteerde opdrachtgestuurde concepten en de mate waarin deze concepten juist zijn geïnterpreteerd. De combinatie van deze criteria leidt tot de globale indeling sterk, gemiddeld, zwak. De sleutel voor deze indeling is weergegeven in Tabel $6.2^{10}$.

Tabel 6.2 Sleutel voor globale beoordeling van presentaties

\begin{tabular}{l|l|l} 
& Aantal concepten & Mate van adequate interpretatie \\
\hline Sterk & 4,5 & helemaal juist \\
\hline Gemiddeld & 4,5 & grotendeels juist/deels onjuist \\
\hline Zwak & 3 of minder & - \\
& $1,2,3,4,5$ & grotendeels onjuist
\end{tabular}

Bij iedere presentatie is het aantal concepten beoordeeld met een + of -. De kwaliteit van de interpretatie van de concepten is globaal beoordeeld met helemaal juist $(+)$, grotendeels juist, maar niet helemaal $( \pm)$ of grotendeels onjuist $(-)$. De onderzoeker en een docent hebben ieder apart een globale beoordeling gegeven. De uiteindelijke beoordeling is tot stand gekomen door hun beoordelingen te vergelijken, waarbij geen verschillen werden geconstateerd.

Sterk zijn presentaties met twee maal een + , zwak zijn presentaties met eenmaal of tweemaal -, gemiddeld zijn presentaties met + en \pm . Tabel 6.3 geeft een overzicht van de verdeling van het aantal presentaties in de categorieën sterk, gemiddeld, zwak.

Tabel 6.3 Verdeling van presentaties naar videocasus en globale beoordeling

\begin{tabular}{l|l|l|l} 
& Sterk & Gemiddeld & Zwak \\
\hline Videocasus 1 (Ouder de klas uit) & 4 & 2 & 2 \\
\hline Videocasus 2 (Inschakelen ouder) & 2 & 3 & 1 \\
\hline Videocasus 3 (Agressieve ouder) & 2 & 3 & 2 \\
\hline Totaal & 8 & 8 & 5
\end{tabular}

10 Bij casus 3, De agressieve ouder, konden maximaal zes concepten worden toegepast. Daarom gelden iets andere getallen voor de globale indeling in sterk $(5,6)$, gemiddeld $(4,5,6)$ en zwak $(1 \mathrm{t} / \mathrm{m} 6)$ voor die casus . 
De eenentwintig presentaties betreffen drie verschillende onderwerpen (Inschakelen ouder, Ouder de klas uit en Agressieve ouder). Per onderwerp zijn een sterke en een zwakke presentatie geselecteerd, zodat een breed beeld van het gehele onderwijsarrangement wordt gegeven en eventuele verschillen die veroorzaakt worden door typische onderwerpskenmerken, ondervangen worden. De uiteindelijke keuze voor de te onderzoeken presentaties is ten slotte at random gemaakt, behalve bij videocasus 1 waar maar één zwakke presentatie was. De geselecteerde zwakke gevallen scoorden verschillend op de beide selectiecriteria. Bij videocasus 2 scoorde de zwakke presentatie twee maal een min, bij de andere videocases werd één min gescoord: videocasus 1 (- en +), videocasus 2 (- en - ) en videocasus 3 (+ en -).

\section{Instrument}

Voor het bepalen van de manier waarop en de kwaliteit waarmee studenten concepten hanteren, wordt in deze studie aangesloten bij Oonk (2009) die het gebruik van conceptuele kennis door studenten analyseert aan de hand van twee aspecten: de aard en het niveau van theoriegebruik. Het bestaande analyse-instrument van Oonk (2009) is wat betreft de aard van het theoriegebruik aangepast. Het oorspronkelijke instrument bevat hiervoor vier categorieën: beschrijven, interpreteren, verklaren en inspelen op. In het aangepaste instrument worden twee categorieën onderscheiden: beschrijven en verklaren.

Bij het beschrijven worden gebeurtenissen en/of handelingen feitelijk beschreven zonder daaraan een waardeoordeel of conclusie te verbinden. Bij het verklaren wordt uitgelegd waarom een bepaalde handeling plaatsvindt of waarom iets wordt gedacht. Kenmerkende woorden voor deze categorie zijn woorden die een causale relatie uitdrukken of een anderszins redenerend verband tonen zoals 'dus, om, want, omdat, zo, daarom' et cetera.

Het oorspronkelijke instrument bevat ook de categorieën 'interpreteren' en 'inspelen op'. Deze beide vormen van theoriegebruik zijn niet opgenomen in het aangepaste analyse-instrument gezien de aard van de opdracht aan studenten. Het eerste deel van de opdracht (conceptuele verdieping) vraagt studenten weliswaar een communicatieve situatie te interpreteren, maar vervolgens wordt van hen gevraagd om alternatief handelen ten opzichte van de bestudeerde videocasus te laten zien in eigen videobeelden en dit te verantwoorden in een mondelinge toelichting (toepassing). De interpretatie van een videocasus gaat dus vooraf aan de presentatie van eigen videobeelden. In de presentatie van de eigen videobeelden is het dan niet logisch de eigen videobeelden weer te interpreteren. De categorie 'inspelen op' (anticiperen, mogelijk vervolg of alternatief ontwerpen) is ook niet van toepassing gezien de aard van de opdracht. In de voorliggende studie benoemen studenten mogelijk alternatief gedrag niet, ze tonen dat alternatieve gedrag in videobeelden. 'Inspelen op' is daarom geen relevante categorie in het kader van deze studie. 
Het niveau van theoriegebruik wordt onderscheiden in drie categorieën met de volgende kenmerken:

1. Geen zichtbaar gebruik van theorie

- Concepten uit het conceptueel kader worden niet gehanteerd; of

- Concepten worden foutief gehanteerd.

Toelichting: Op niveau 1 ontbreken concepten ontbreken en wordt alleen alledaagse taal gehanteerd of concepten worden wel gehanteerd, maar zodanig verkeerd dat geen zinvolle uitspraken ontstaan.

2. Reproductief gebruik van theorie

- Relevant gebruik van één concept; of

- Twee of meer concepten worden gebruikt, zonder dat er sprake is van zichtbaar inzicht in de samenhang tussen de concepten.

Toelichting: Op niveau 2 vindt vooral reproductie van theorie plaats. In uitspraken waarbij gebruik wordt gemaakt van een concept, wordt nauwelijks/eenvoudig geredeneerd.

3. Integratie van theorie

- Twee of meer concepten worden gebruikt, met zichtbaar inzicht in de samenhang tussen de concepten.

Toelichting: In uitspraken op niveau 3 wordt logisch geredeneerd (wat herkenbaar is aan constructies zoals 'als ... dan, het gebruik van argumenten, het leggen van verbanden, het maken van generalisaties) of wordt verwezen naar literatuur. Soms wordt een eigen theorie geformuleerd of vindt reconstructie van theorie plaats.

Het aangepaste instrument is weergegeven in Tabel 6.4 en levert zes mogelijke categoriseringen op van uitspraken van studenten: beschrijven en verklaren kunnen beide op drie niveaus plaatsvinden.

Tabel 6.4 Instrument voor analyse van aard en niveau conceptgebruik

\begin{tabular}{|c|c|c|}
\hline & $\begin{array}{l}\text { A. Beschrijven } \\
\text { Feiten: wie, wat, waar, hoe }\end{array}$ & $\begin{array}{l}\text { C. Verklaren } \\
\text { o.a. uitleg van het waarom }\end{array}$ \\
\hline Niveau 1 & $\begin{array}{l}\text { A1 } \\
\text { Feitelijke beschrijving van de } \\
\text { communicatieve situatie zonder } \\
\text { gebruik van theoretische begrippen } \\
\text { of foutief gebruik }\end{array}$ & $\begin{array}{l}\text { C1 } \\
\text { Verklaring van de communicatieve } \\
\text { situatie zonder gebruik van } \\
\text { theoretische begrippen of foutief } \\
\text { gebruik }\end{array}$ \\
\hline Niveau 2 & $\begin{array}{l}\text { A2 } \\
\text { Feitelijke beschrijving van de } \\
\text { communicatieve situatie met } \\
\text { gebruik van één of meer } \\
\text { theoretische begrippen, zonder } \\
\text { onderlinge samenhang }\end{array}$ & $\begin{array}{l}\text { C2 } \\
\text { Verklaring van de communicatieve } \\
\text { situatie met gebruik van één of meer } \\
\text { theoretische begrippen, zonder } \\
\text { onderlinge samenhang }\end{array}$ \\
\hline Niveau 3 & $\begin{array}{l}\text { A3 } \\
\text { Feitelijke beschrijving van de } \\
\text { communicatieve situatie met } \\
\text { gebruik van twee of meer } \\
\text { theoretische begrippen in } \\
\text { betekenisvolle samenhang }\end{array}$ & $\begin{array}{l}\text { C3 } \\
\text { Verklaring van de communicatieve } \\
\text { situatie met gebruik van twee of meer } \\
\text { theoretische begrippen in } \\
\text { betekenisvolle samenhang }\end{array}$ \\
\hline
\end{tabular}


Om de kwaliteit waarmee de conceptuele structuur in de toelichting op het handelen wordt gehanteerd nader te bepalen, zijn als aanvulling op de aspecten aard en niveau van het conceptgebruik, twee andere aspecten betrokken. Ten eerste is bepaald in hoeverre de conceptuele structuur in de presentatie wordt verbonden aan het eigen professioneel handelen, aangezien dit de specifieke aard van de opdracht is. De leidende vraag hierbij is: Krijgen concepten een specifieke, situatiegebonden invulling? Dit aspect van de presentatie wordt beoordeeld met behulp van drie categorieën: consequent, incidenteel of niet. Ten tweede is, evenals bij de kwantitatieve analyse (zie 6.2), geobserveerd of studenten, naast opdrachtgestuurde concepten, ook spontaan concepten hanteren.

In het onderdeel reflectie op het handelen zijn als aanvulling op de aspecten aard en niveau van het conceptgebruik, ook twee andere aspecten betrokken. In kaart wordt gebracht welke concepten de studenten hanteren (de open opdracht geeft hierin keuzevrijheid) en waarop de reflectie betrekking heeft. Op basis van de data zijn twee situaties afgeleid waarop de reflectie betrekking kan hebben. Deze situaties verschillen in mate van 'nabijheid'. Studenten reflecteren op sterke en zwakke kanten van de eigen communicatieve vaardigheden in (a) de situatie van de getoonde video of (b) situaties uit hun beroepspraktijk.

\section{Dataverwerking}

Van de presentaties is een protocol uitgeschreven dat is opgedeeld in betekenisvolle eenheden voor de analyse. De criteria voor het vaststellen van betekenisvolle analyse-eenheden zijn afgeleid uit de data en betreffen de volgende aspecten:

- Een betekenisvolle eenheid heeft betrekking op de inhoud van de presentatie;

De communicatieve situatie staat centraal in de analyse-eenheid. De presentaties kennen ook niet-inhoudelijke delen. Vaak betreft het structuurelementen, korte delen die de opbouw van de presentatie verhelderen: de aankondiging van een videofragment, de introductie van de presentatie et cetera. Deze stukken worden niet betrokken in de analyse.

- Een betekenisvolle eenheid bevat een thematisch samenhangend onderwerp.

Vaak wordt in de presentatie zelf al duidelijk gemaakt dat er sprake is van een thematisch samenhangend onderwerp, doordat een onderwerp visueel wordt ondersteund met een PowerPoint dia. Segmentering vindt ook op natuurlijke wijze plaats doordat een deel van de presentatie betrekking heeft op één videofragment of doordat wisseling van presentator plaatsvindt. Gemiddeld bevat iedere presentatie acht betekenisvolle eenheden.

\section{Data-analyse}

Voor het beantwoorden van de eerste onderzoeksvraag zijn de betekenisvolle eenheden van iedere presentatie gecategoriseerd met behulp van het instrument (aard en niveau). Per eenheid is met een letter en een cijfer aangegeven tot welke categorie de eenheid wordt gerekend. Per eenheid is tevens beschreven in hoeverre 
de concepten juist zijn geïnterpreteerd door te bestuderen hoe de concepten in de context worden geplaatst.

Concepten zijn in deze studie beschouwd als de begrippen die in de conceptuele structuur zijn opgenomen. De grammaticale verschijningsvorm van een concept kan verschillen vanwege de zinsstructuur waarin het is opgenomen. Zo kan 'informatief doel' (substantief) ook geformuleerd worden als 'Ons belangrijkste doel is informeren' (infinitief). Voor een uitgebreidere beschrijving van de concepten, zie paragraaf 6.2. In Bijlage E wordt van iedere categorie een voorbeeld gegeven met toelichting om een beeld te geven van de data-analyse en de overwegingen die daarin hebben meegespeeld. De voorbeelden zijn afkomstig uit de zes geanalyseerde protocollen.

Bij de analyse van de betekenisvolle eenheden in de toelichting op het handelen is tevens genoteerd of de conceptuele structuur concreet wordt betrokken op het eigen professioneel handelen in de videobeelden. Vervolgens is dit aspect in de presentatie gekarakteriseerd met:

- consequent (in alle analyse-eenheden)

- incidenteel (in minder dan de helft van de analyse-eenheden)

- niet.

Tevens is bepaald of en zo ja welke concepten spontaan zijn opgenomen in de toelichting door te vergelijken welke concepten tot de opdrachtgestuurde behoren en welke daarnaast nog gebruikt zijn.

Bij de betekenisvolle eenheden die betrekking hebben op de reflectie op het handelen is genoteerd welke concepten in de reflectie worden betrokken en op welke situatie de reflectie betrekking heeft.

Om de betrouwbaarheid van de analyse te vergroten, is iedere presentatie door twee beoordelaars geanalyseerd. Drie beoordelaars zijn betrokken in de analyse: de onderzoeker, een inhoudsdeskundige (docent) en een ervaringsdeskundige (student). De onderzoeker heeft alle gevallen geanalyseerd, de beide tweede beoordelaars ieder drie gevallen. Bij verschil van inzicht is het betreffende videofragment opnieuw bekeken en is het protocol opnieuw bestudeerd, waarna door middel van discussie consensus is gezocht. Verschillen in analyse tussen de tweede beoordelaars zijn niet geconstateerd.

Bij de toelichting op het handelen zijn in totaal 36 eenheden geanalyseerd. Over 25 eenheden (70\%) was onmiddellijk consensus, over 11 eenheden (30\%) is gediscussieerd door de eerste en tweede beoordelaar en is in alle gevallen tot een eensluidend oordeel gekomen. Bij de bediscussieerde eenheden is 6 maal over de aard, 4 maal over het niveau en 1 maal over beide gesproken.

Het onderdeel 'reflectie' is ook door twee beoordelaars gescoord. Aan één presentatie ontbrak de reflectie en daarom is het totaal aantal reflecties vijf in plaats van zes. Over drie reflecties is gesproken, met name over de aard van de reflectie. De discussie werd veroorzaakt doordat de reflectie aanvankelijk als één betekenisvolle eenheid werd beschouwd waarbinnen soms verscheidene studenten het woord nemen. $\mathrm{Na}$ discussie is tot consensus gekomen door in die gevallen de eenheid te 
verkleinen tot de inbreng van één student, waarmee recht wordt gedaan aan de verschillen tussen studenten op dit vlak.

Voor het in kaart brengen van de manier waarop studenten verschillende perspectieven op de communicatieve situatie betrekken in hun toelichting, is de volgende werkwijze gehanteerd. Bij iedere analyse-eenheid is genoteerd welke perspectieven op de communicatieve situatie studenten laten meeklinken in hun toelichting. (Gebleken is dat studenten naast de perspectieven van leerkracht, ouder en school ook die van het kind betrekken). Vervolgens zijn uit de data twee kenmerken afgeleid voor de wijze waarop die perspectieven worden uitgewerkt. Van elk perspectief wordt beschreven (a) de wijze waarop het perspectief wordt verwoord (impliciet of expliciet) en (b) de mate waarin het perspectief wordt verwoord (uitgebreid of beperkt).

\subsection{Resultaten}

In deze paragraaf worden de resultaten van de analyse weergegeven in drie onderdelen: het conceptgebruik in de toelichting op het handelen, het conceptgebruik in de reflectie en het innemen van perspectieven.

Per onderdeel wordt dezelfde opbouw gehanteerd. Eerst worden de resultaten van de drie sterke gevallen weergegeven (geval 1, 2 en 3), gevolgd door de resultaten van de drie zwakke gevallen (geval 4, 5 en 6). Daarna vindt een duiding plaats van de sterke en van de zwakke gevallen. Tenslotte wordt een vergelijking getrokken tussen de sterke en de zwakke gevallen om tot conclusies te komen.

\subsubsection{Conceptgebruik in toelichting op handelen}

\subsubsection{Resultaten}

Per geval is onderzocht wat aard en niveau van het conceptgebruik zijn in de toelichting op het handelen door de analyse-eenheden te categoriseren. Daarnaast is per geval gekeken in hoeverre de conceptuele structuur gerelateerd wordt aan concrete voorbeelden van eigen communicatief gedrag en of concepten spontaan worden geïntegreerd in de toelichting. In Tabel 6.5 is voor alle zes gevallen een overzicht gegeven van de onderzochte aspecten. Bij alle gevallen worden specifieke kenmerken of zaken die aanvullend zijn op het overzicht genoteerd om recht te doen aan het kwalitatieve karakter van de analyse. 
Tabel 6.5 Aard en niveau van conceptgebruik, relatie met handelen en spontaan gebruik concepten in toelichting

\begin{tabular}{|c|c|c|c|c|c|c|}
\hline \multirow[t]{2}{*}{ Geval } & \multirow[t]{2}{*}{ Aard CG } & \multicolumn{3}{|c|}{$\begin{array}{l}\text { Niveau } \\
\text { CG }\end{array}$} & \multirow[t]{2}{*}{$\begin{array}{l}\text { Relatie met } \\
\text { handelen }\end{array}$} & \multirow[t]{2}{*}{ Spontaan gebruik concepten } \\
\hline & & 1 & 2 & 3 & & \\
\hline 1 sterk & $\begin{array}{l}\text { Beschrijven } \\
\text { Verklaren }\end{array}$ & 1 & & 3 & consequent & $\begin{array}{l}\text { gespreksvaardigheden (open } \\
\text { lichaamshouding, luisteren, doorvragen, } \\
\text { rustig stemgebruik) }\end{array}$ \\
\hline 2 sterk & $\begin{array}{l}\text { Beschrijven } \\
\text { Verklaren }\end{array}$ & & & 1 & consequent & $\begin{array}{l}\text { expressieve, relationele, appellerende } \\
\text { boodschap }\end{array}$ \\
\hline 3 sterk & $\begin{array}{l}\text { Beschrijven } \\
\text { Verklaren }\end{array}$ & & 5 & 1 & consequent & - \\
\hline 4 zwak & $\begin{array}{l}\text { Beschrijven } \\
\text { Verklaren }\end{array}$ & 1 & 3 & & incidenteel & $\begin{array}{l}\text { gespreksvaardigheden (begrip tonen, } \\
\text { open en gesloten vragen stellen, mimiek, } \\
\text { oogcontact, gebaren, lichaamshouding) }\end{array}$ \\
\hline 5 zwak & $\begin{array}{l}\text { Beschrijven } \\
\text { Verklaren }\end{array}$ & 2 & $\begin{array}{l}1 \\
3\end{array}$ & 1 & incidenteel & zender, ontvanger \\
\hline 6 zwak & \begin{tabular}{|l} 
Beschrijven \\
Verklaren
\end{tabular} & 1 & $\begin{array}{l}1 \\
1\end{array}$ & & incidenteel & communicatief doel, persuasief, affectief \\
\hline
\end{tabular}

Noot. $\mathrm{CG}=$ conceptgebruik

aNiveau 1 = zonder gebruik van concepten of foutief gebruik; Niveau 2 = gebruik van één of meer concepten zonder zichtbare samenhang; Niveau 3 = gebruik van twee of meer concepten met zichtbare samenhang. bDe getallen verwijzen naar het aantal analyse-eenheden eenheden per niveau. Het totaal aantal analyse-eenheden per geval varieert van 3 tot 8 .

\section{Geval 1 sterk}

In geval 1 worden alle opdrachtgestuurde concepten gebruikt en wordt drie keer een verband gelegd tussen verschillende concepten. Zo worden bijvoorbeeld onderwijscontext en gespreksvaardigheden aan elkaar verbonden.

Geval 2 sterk

In geval 2 valt op dat de concepten 'expressieve, relationele en appellerende boodschap' herhaaldelijk worden toegepast.

\section{Geval 3 sterk}

In geval 3 valt op dat de aard van twee analyse-eenheden buiten de categorieën van het analysekader valt. In deze analyse-eenheden wordt weliswaar verklaard, maar de verklaring betreft niet de communicatieve situatie. De studenten geven op interactieve wijze uitleg over bepaalde casusgebonden concepten zelf (emotionele/instrumentele agressie en het 7-stappenplan voor de fasering van een gesprek met agressie) voordat ze worden toegepast op de communicatieve situatie.

Geval 4 zwak

Het conceptgebruik in geval 4 is een mengeling van juist, deels onjuist of beperkt geïnterpreteerde concepten op niveau 2, wat leidt tot beschrijvingen die van beperkte waarde zijn. Op niveau 1 worden wel verscheidene concepten gehanteerd, maar de interpretatie ervan is inadequaat en leidt tot een onjuiste beschrijving. Enkele opdrachtgestuurde concepten ontbreken. 


\section{Geval 5 zwak}

In geval 5 laat het conceptgebruik op niveau 2 een diffuus beeld zien: een enkel concept wordt uitgebreid besproken, andere concepten zijn onvolledig geïnterpreteerd, twee concepten ontbreken.

Geval 6 zwak

In geval 6 is een mengeling zichtbaar van juist, deels onjuist of beperkt geïnterpreteerde concepten op niveau 2. In geval 6 is de manier waarop spontaan gehanteerde concepten in de presentatie zijn opgenomen, afwijkend. Dit gedeelte van de presentatie wordt niet ondersteund door een PowerPointdia en wordt op een onlogisch moment toegevoegd, namelijk nadat de reflectie op het handelen al heeft plaatsgevonden. Hiermee wordt de indruk gewekt dat de student dit onderdeel improviseert naar aanleiding van voorgaande presentaties waarin andere groepjes studenten deze concepten ook toepasten. Een deel van deze concepten is, net als bij de opdrachtgestuurde concepten, onjuist geïnterpreteerd.

\subsubsection{Duiding van sterke gevallen}

Aard van theoriegebruik

In de sterke presentaties ligt het accent op het verklaren. De studenten zijn erop gericht uit te leggen waarom ze een bepaalde aanpak hebben gekozen. In geval 1 en 3 wordt overwegend verklaard, maar in geval 2 wordt bijna evenveel beschreven als verklaard.

\section{Niveau van theoriegebruik}

Het theoretisch begrippenkader wordt in de sterke presentaties op niveau 2 en 3 toegepast; niveau 1 waarbij geen concepten worden gebruikt, komt eenmaal voor. Getalsmatig is de verhouding voor niveau 1, 2 en 3 als volgt: 1-14-5. Het meest voorkomende niveau waarop concepten worden toegepast, is niveau 2.

Vrijwel altijd gebruiken studenten bij niveau 2 niet slechts één, maar meer concepten om een beschrijving of verklaring te geven. Inhoudelijk worden zinvolle aspecten van het communicatieve gedrag verklaard of beschreven met behulp van die concepten, waarmee een diepgaand begrip van de situatie wordt getoond. De redeneringen in de presentaties blijven vaak impliciet. Door het ontbreken van een expliciet redenerend verband, blijven verscheidene benoemde aspecten 'naast' elkaar staan in plaats van logisch te worden verbonden. Aan de hand van een voorbeeld wordt dit geïllustreerd.

'De appellerende boodschap van Jennifer is eigenlijk het aanzetten of motiveren tot een andere activiteit. Die hulp hebben we dus eigenlijk niet nodig, maar er zijn, wat [onverstaanbaar] ook al vertelde, wel heel veel andere dingen waar we hulp van ouders wel bij nodig hebben. Dus Jennifer probeert in dit geval de ouder te motiveren om een andere activiteit te doen zodat ze zich toch nog een beetje gewaardeerd voelt omdat ze ja, eigenlijk toch wordt afgewezen. De expressieve boodschap, ik vond hem bij Jennifer best wel heel erg zeker. Jennifer komt heel ... ze straalt wel overtuigingskracht uit en lijkt wel heel zeker van haar zaak. Ik vind 
dat je een beetje verschil kan zien met Carien, die komt toch iets meer onzeker over en Jennifer is wat zekerder in dit geval. De relationele boodschap: Jennifer weet dat de ouder heel hulpvaardig is, dat ze heel enthousiast is om haar hulp aan te bieden, om te helpen bij allerlei dingen en tegelijkertijd weet ze ook dat die ouder het heel jammer vindt. Dus ze probeert voorzichtig een beetje de boodschap te geven, dus dat ze de ouder niet wil teleurstellen, om haar dus af te wijzen, maar dat ze wel een andere opdracht, een andere activiteit kan begeleiden. Dat hangt een beetje met elkaar samen' (uit geval 2).

In dit fragment wordt een verklaring gegeven voor het communicatieve gedrag van de leerkracht, waarbij de appellerende, relationele en expressieve boodschap relevant zijn. Aan de appellerende en relationele boodschap wordt ook een redenering verbonden: eerst worden ze benoemd en vervolgens wordt beredeneerd waarom ze in deze context zinvol zijn. De concepten worden echter niet met behulp van een duidelijke redenering aan elkaar verbonden. Van zichtbare betekenisvolle samenhang tussen concepten is dus geen sprake.

In elke sterke presentatie komt niveau 3, waarbij zichtbaar verband wordt gelegd tussen verscheidene concepten, wel voor. In geval 1 wordt dit zichtbare verband driemaal gelegd, in geval 2 en 3 vindt dit eenmaal plaats.

\section{Relatie met het handelen}

Kenmerkend voor de sterke presentaties is dat de concepten worden geconcretiseerd en consequent worden gerelateerd aan concrete voorbeelden van eigen communicatief gedrag. Een voorbeeld waarbij de begrippen expressieve en relationele boodschap worden geconcretiseerd, illustreert dit:

[Op PowerPointdia worden de volgende begrippen vertoond: expressief $>$ rust, stemgebruik, lichaamshouding relationeel > gelijkwaardig, belangstellend]

'M. Ik zal verder vertellen. Het leerkrachtgedrag, dat hier dan heel kort te zien is, straalt rust uit enne ... waarbij we dan ook heel rustig vertellen van 'Wat is er nou aan de hand' (...) Het stemgebruik was dan heel rustig, dat is dan verbaal, om aan te geven dat je wel de tijd neemt voor die moeder. Lichaamshouding was ook open, en $\mathrm{uhm}$, hier liet ze ook de pen, ik legde de pen weg om aan te geven dat ik tijd nam voor die moeder, dat ik er tijd voor had om even te luisteren. Ik ging ook open staan, zo van, laat maar zien wat er aan de hand is.

Op relationeel gebied staan we gelijkwaardig, door open te staan en te laten zien dat ik wil luisteren, dat ik tijd voor haar heb, en ik ben belangstellend. Dat deed ik door dus door te vragen wat er nou aan de hand was, wat er precies was gebeurd. En door mijn houding, door dat te laten zien' (uit geval 1).

Dit fragment laat zien dat abstracte begrippen een specifieke situatiegebonden inhoud krijgen en dat een concreet verband wordt gelegd met zichtbaar communicatief gedrag. 
Spontaan gehanteerde concepten

Concepten worden in twee sterke gevallen ook spontaan geïntegreerd in de toelichting. De concepten zijn juist geïnterpreteerd en gerelateerd aan het professioneel handelen.

Samengevat: In de sterke presentaties blijken studenten de conceptuele structuur adequaat te hanteren. Het hanteren van concepten gebeurt voornamelijk op niveau 2, maar in iedere presentatie wordt incidenteel ook het hoogste niveau (3) bereikt. Spontaan worden in twee gevallen concepten toegevoegd naast de opdrachtgestuurde concepten. Daarbij wordt in de sterke presentaties de relatie met het eigen professioneel handelen consequent gelegd en ligt het accent op het verklaren van de communicatieve situatie. Inhoudelijk houden de studenten een correct betoog dat getuigt van begrip van de situatie; de redeneringen binnen dat betoog blijven vaak impliciet.

\subsubsection{Duiding van zwakke gevallen}

\section{Aard van theoriegebruik}

De aard van het conceptgebruik in de zwakke presentaties is sterk uiteenlopend: in geval 4 wordt uitsluitend beschreven, in geval 5 wordt overwegend verklaard en in geval 6 wordt meer beschreven dan verklaard.

Niveau van theoriegebruik

De conceptuele structuur wordt in de zwakke presentaties op niveau 1 en 2 toegepast, niveau 3 komt eenmaal voor. Getalsmatig is de verhouding voor niveau 1 , 2 en 3 als volgt: 4-9-1. Het conceptueel kader wordt voornamelijk toegepast op niveau 2 en enkele keren op niveau 1.

De manier waarop de concepten op niveau 2 worden toegepast is zeer uiteenlopend. In geval 4 en 6 worden meerdere concepten gehanteerd, maar is een mengeling zichtbaar van juist en onjuist geïnterpreteerde concepten. Deze conceptuele onduidelijkheid leidt tot beschrijvingen die inhoudelijk zowel sterke als zwakke elementen bevatten. In geval 5 echter worden de weinige concepten grotendeels juist geïnterpreteerd.

In elke zwakke presentatie komt niveau 1 voor, maar niet op dezelfde wijze. Ook hierin onderscheidt geval 5 zich van beide andere presentaties: in geval 5 ontbreken concepten en in geval 4 en 6 worden concepten onjuist geïnterpreteerd wat leidt tot onjuiste, irrelevante uitspraken

In alle drie gevallen ontbreken bepaalde opdrachtgestuurde concepten waardoor relevante aspecten van de communicatieve situatie niet aan de orde komen. Dit leidt tot een beperkte inhoudelijke toelichting, wat in de gevallen 4 en 6 ook zichtbaar is aan het lage aantal analyse-eenheden. Geval 5 onderscheidt zich in aard en niveau van het conceptgebruik van de andere twee.

\section{Relatie met het handelen}

Kenmerkend voor de zwakke presentaties is dat de concepten niet consequent worden verbonden aan concrete voorbeelden van eigen communicatief gedrag. 
Incidenteel gebeurt het wel en het niveau hiervan varieert: soms worden concepten goed geconcretiseerd en gerelateerd aan voorbeelden van communicatief gedrag, maar soms worden concepten alleen genoemd en ontbreekt de relevantie in relatie tot het handelen.

Spontaan gehanteerde concepten

Concepten worden spontaan geïntegreerd in alle zwakke presentaties. In geval 4 worden gespreksvaardigheden adequaat benoemd, maar niet verbonden aan het eigen handelen. In geval 5 gaat het om concepten die weinig toegevoegde waarde hebben in het betreffende fragment. Bij geval 6 worden de concepten deels juist en deels onjuist geïnterpreteerd en wordt dit onderdeel hoogstwaarschijnlijk geïmproviseerd.

Samengevat: In de zwakke presentaties worden de concepten hoofdzakelijk toegepast op niveau 2 en in alle presentaties incidenteel op niveau 1. Binnen deze niveaus is variatie zichtbaar: In geval 5 is sprake van onvolledigheid (maar niet van misinterpretatie), in geval 4 en 6 is sprake van een diffuus begrip van concepten. De zwakke presentaties verschillen in de aard waarmee concepten worden toegepast: zowel overwegend verklaren (geval 5) als uitsluitend beschrijven (geval 4) als een combinatie van beide (geval 6) vindt plaats. Geconcludeerd wordt dat geval 5 qua aard van het conceptgebruik overeenkomsten met de sterke gevallen vertoont en qua niveau van het conceptgebruik een tussenpositie inneemt tussen sterk en zwak.

Spontaan worden in alle drie presentaties concepten toegevoegd. Gemeenschappelijk in de zwakke presentaties is ook de incidentele relatie die wordt gelegd met het eigen handelen. De inhoudelijke interpretatie van de communicatieve situatie ten slotte kent beperkingen doordat relevante aspecten van de communicatieve situatie ontbreken of onvolledig worden uitgewerkt. Kortom, de zwakke presentaties vertonen zowel sterke als zwakke elementen, in een unieke combinatie.

\subsubsection{Vergelijking van sterke en zwakke gevallen}

Bij een vergelijking van de sterke en zwakke presentaties, ontstaat het volgende beeld over het gebruik van concepten:

1. In de sterke presentaties is een duidelijke tendens zichtbaar naar verklaring van het communicatieve gedrag en de communicatieve situatie. De bevindingen zijn voor de zwakke presentaties op dit vlak diffuus.

2. In de sterke presentaties wordt de conceptuele structuur voornamelijk op niveau 2 toegepast en komt niveau 3 in iedere presentatie voor. Niveau 1 komt nauwelijks voor. In de zwakke presentaties wordt de conceptuele structuur voornamelijk op niveau 2 toegepast en komt niveau 1 in iedere presentatie voor. Niveau 3 komt nauwelijks voor.

3. In de sterke presentaties wordt de conceptuele structuur consequent verbonden aan concrete voorbeelden van eigen handelen; in de zwakke presentaties gebeurt dit incidenteel. 
4. Er is geen verschil tussen sterke en zwakke presentaties in het opnemen van spontaan toegevoegde concepten in de toelichting; in de sterke presentaties worden de concepten wel adequater geïnterpreteerd en verbonden aan het eigen handelen.

5. De inhoudelijke interpretatie van de communicatieve situatie is bij de zwakke presentaties beperkter dan bij de sterke gevallen: relevante aspecten van de communicatieve situatie ontbreken of worden onvolledig uitgewerkt waardoor het begrip van de situatie minder diepgang heeft.

\subsubsection{Conceptgebruik in reflectie ${ }^{11}$}

\subsubsection{Resultaten}

Bij de reflectie op het handelen hebben studenten de ruimte zelf relevante concepten te kiezen. Onderzocht is welke concepten de studenten spontaan hanteren en wat de aard en het niveau van dit conceptgebruik is. Deze aspecten worden weergegeven in kolom 2, 3 en 4 van Tabel 6.6. Tevens is onderzocht op welke situatie de reflectie betrekking heeft; dit is weergegeven in kolom 5. Studenten reflecteren op hun communicatieve vaardigheden in de concrete situatie van de videobeelden of op concrete situaties in de beroepspraktijk (stage).

Tabel 6.6 Aard en niveau van conceptgebruik, soort concepten en situatie in reflectie

\begin{tabular}{|c|c|c|c|c|c|c|}
\hline \multirow[t]{2}{*}{ Geval $^{\mathrm{a}}$} & \multirow[t]{2}{*}{ Aard CG } & \multicolumn{3}{|c|}{$\begin{array}{l}\text { Niveau } \\
\text { CGbc }\end{array}$} & \multirow[t]{2}{*}{ Concepten } & \multirow{2}{*}{$\begin{array}{l}\text { Situatie } \\
\text { Sterke/zwakke } \\
\text { kanten in: }\end{array}$} \\
\hline & & 1 & 2 & 3 & & \\
\hline 1 & $\begin{array}{l}\text { Beschrijven } \\
\text { Verklaren }\end{array}$ & & 1 & & $\begin{array}{l}\text { persuasief, motiverend en } \\
\text { affectief doel }\end{array}$ & videobeelden \\
\hline 2 & $\begin{array}{l}\text { Beschrijven } \\
\text { Verklaren }\end{array}$ & $\begin{array}{l}2 \\
1\end{array}$ & 1 & & relationele boodschap & $\begin{array}{l}\text { videobeelden } \\
\text { beroepspraktijk }\end{array}$ \\
\hline 3 & $\begin{array}{l}\text { Beschrijven } \\
\text { Verklaren }\end{array}$ & 1 & & 1 & $\begin{array}{l}\text { gespreksvaardigheden (open } \\
\text { houding, inspelen op, luisteren), } \\
\text { soorten agressie }\end{array}$ & videobeelden \\
\hline 4 & $\begin{array}{l}\text { Beschrijven } \\
\text { Verklaren } \\
\end{array}$ & & 1 & & $\begin{array}{l}\text { relationele boodschap, affectieve } \\
\text { boodschap }\end{array}$ & videobeelden \\
\hline 6 & $\begin{array}{l}\text { Beschrijven } \\
\text { Verklaren }\end{array}$ & 1 & $\begin{array}{l}1 \\
2\end{array}$ & & $\begin{array}{l}\text { gespreksvaardigheden } \\
\text { (oogcontact, open houding, rust } \\
\text { creëren, luisteren, } \\
\text { laten uitpraten, samen uitkomen) }\end{array}$ & $\begin{array}{l}\text { videobeelden } \\
\text { beroepspraktijk }\end{array}$ \\
\hline
\end{tabular}

Noot. $\mathrm{CG}=$ conceptgebruik; $\mathrm{CV}=$ communicatieve vaardigheden.

${ }^{a}$ Van geval 5 ontbreekt de reflectie. ${ }^{b}$ Niveau $1=$ zonder gebruik van concepten of foutief gebruik; Niveau 2 = gebruik van één of meer concepten zonder zichtbare samenhang; Niveau 3 = gebruik van twee of meer concepten met zichtbare samenhang. "De getallen verwijzen naar het aantal analyse-eenheden eenheden per niveau. Het totaal aantal analyse-eenheden per geval varieert van 1 tot 4 .

11 In deze paragraaf worden de resultaten van sterke en zwakke gevallen niet apart weergegeven. Zie voor verantwoording paragraaf 6.5. 


\subsubsection{Duiding van alle gevallen}

De reflecties variëren in aard van het conceptgebruik: zowel beschrijven (geval 3 en 4) als verklaren (geval 1) als een combinatie van beide (geval 2 en 6) komt voor.

In alle gevallen worden spontaan concepten gehanteerd bij de reflecties op het professioneel handelen.

Getalsmatig is de verhouding voor niveau 1, 2 en 3 als volgt: 5-6-1. Dit betekent dat in ruim de helft van de analyse-eenheden concepten worden gehanteerd. Het meest voorkomende niveau waarop concepten worden toegepast, is niveau 2; niveau 3 komt eenmaal voor in geval 3 . In drie gevallen $(2,3$ en 6$)$ bevatten de reflecties een combinatie van analyse-eenheden waarin wel concepten worden gebruikt én analyseeenheden waarin geen concepten worden gebruikt (niveau 1).

De reflectie heeft inhoudelijk (qua situatie) in alle gevallen betrekking op de communicatieve vaardigheden van de studenten in de getoonde videobeelden. Een voorbeeld hiervan:

'Bij de sterke punten hadden we persuasief, overtuigen van iets en motiverend: aanzetten tot iets. We wilden graag dat die ouder met een fijn gevoel de klas weer uitging en toch met een oplossing komen, ondanks dat je tijdgebrek hebt. En affectief: laten merken dat je meeleeft. Dat je wel begrip hebt voor de reactie van de ouder en dat je dat dan ook laat merken naar de ouder toe' (uit geval 1).

In twee gevallen reflecteren de studenten daarnaast op hun communicatieve gedrag in de beroepspraktijk (stage). In geval 2 reflecteert een student op een concrete ervaring met een oudergesprek en hanteert hierbij ook een concept. Dit getuigt van transfer waarbij een concept wordt toegepast op een geheel andere situatie:

'Ik denk dat mijn sterke kant met betrekking tot dit onderwerp is dat ik ... mijn relationele boodschap is over het algemeen vaak wel goed. Ik heb zelf met een geschiedenisportfolio de hulp van ouders ingeschakeld, dat de kinderen spulletjes van huis mee moesten nemen. Dat had ik gedaan door middel van een briefje. Daarna had ik dus een ouder die kwam naar mij toe en die zei 'het was een heel probleem met die leerling, want die had geen contact meer met zijn opa's en oma's. Dus daarom moest ik wel een beetje heel begripvol zijn en dat gaat me over het algemeen wel goed af. Wat mijn mindere kanten zijn, is dat ik wel goed voorbereid moet zijn op zo'n gesprek, want als ik onvoorbereid zo'n gesprek in moet gaan, weet ik soms niet helemaal wat ik moet zeggen. Ik moet wel even weten van tevoren waar het over gaat om zo'n gesprek goed en netjes af te kunnen ronden' (uit geval 2).

In geval 6 wordt ook gereflecteerd op de communicatieve vaardigheden in de beroepspraktijk. Dit gebeurt in hypothetische zin, dat wil zeggen dat de reflectie gaat over een situatie die denkbaar is maar zich nog niet heeft voorgedaan. Dat wordt met het volgende fragment geïllustreerd:

'Aan de ene kant kan ik wel iemand uit laten praten denk ik, maar ik ben iemand die altijd heel erg mijn gelijk wil hebben. En misschien is dat niet heel erg handig. Ik wil wel gelijk hebben, maar als de ouder het er niet mee eens is, dan is het 
misschien verstandig om toch sommige dingen te laten voor wat het is. Dat is gewoon een zwak punt van mij. En het sterke punt is uh dat ik wel uh heel goed luister naar die persoon, en dat ik wel graag wil dat we er op een goede manier samen uitkomen. Dat iedereen positief zeg maar, na het gesprek weg kan gaan' (uit geval 6).

Samengevat: Studenten gebruiken in alle reflecties concepten om hun professioneel handelen te beschrijven en/of te verklaren. In alle gevallen heeft de reflectie betrekking op de situatie in de videobeelden, in twee gevallen trekken studenten de reflectie breder en reflecteren zij ook op hun beroepspraktijk.

\subsubsection{Conclusie}

Over het gebruik van concepten in de reflectie op het handelen wordt het volgende geconcludeerd:

1. Alle reflecties op het professioneel handelen bevatten spontaan gehanteerde concepten op niveau 2; De reflecties variëren in aard van het conceptgebruik.

2. Inhoudelijk hebben alle reflecties betrekking op de communicatieve vaardigheden in de videosituatie; in twee gevallen wordt ook gereflecteerd op situaties in de beroepspraktijk. Eén geval van transfer treedt hierbij op.

Het spontaan gebruik van concepten in de reflectie laat zien dat studenten zich de conceptuele structuur eigen weten te maken en hun professioneel handelen weten te beschrijven met behulp van enige abstractie. Dat gebeurt echter niet in alle analyseeenheden. In die gevallen waar meer studenten het woord nemen (geval 2, 3, 6) integreert niet iedere individuele student concepten in de reflectie.

De reflecties worden ten slotte gekenmerkt door een openhartige en kritische houding ten opzichte van de eigen communicatieve vaardigheden.

\subsubsection{Innemen van diverse perspectieven}

\subsubsection{Resultaten}

Onderzocht is welke perspectieven op de communicatieve situatie de studenten betrekken in hun toelichting. Daarbij is onderscheiden of dit expliciet of impliciet is verwoord en met welke mate van uitgebreidheid. In Tabel 6.7 is hiervan een overzicht gegeven. Vervolgens wordt per geval aanvullende informatie gegeven over de wijze waarop verscheidene perspectieven worden betrokken in de toelichting 
Tabel 6.7 Perspectieven op de communicatieve situatie

\begin{tabular}{c|l|l|l|l|l|l|l|l} 
Geval & \multicolumn{2}{l}{ Leerkracht/ } & Ouder & \multicolumn{2}{l}{ School } & \multicolumn{2}{l}{ Kind } \\
& stagiaire & \multicolumn{2}{l}{} & \multicolumn{2}{l}{} \\
\hline & Wijze & Mate & Wijze & Mate & Wijze & Mate & Wijze & Mate \\
\hline 1 & expl & + & expl & + & & & expl & + \\
\hline 2 & expl & + & expl & + & expl & + & & \\
\hline 3 & expl & + & expl & + & expl & + & & \\
\hline 4 & expl & + & impl & \pm & & & & \\
\hline 5 & expl & + & expl & \pm & expl & + & & \\
\hline 6 & expl & + & impl & \pm & expl & \pm & expl & \pm
\end{tabular}

Noot. expl $=$ expliciet; impl $=$ impliciet; $+=$ uitgebreid; $\pm=$ beperkt.

\section{Geval 1 sterk}

In de presentatie is expliciet ruimte voor het perspectief van de leerkracht/stagiaire, de ouder en de betrokken kinderen (relevante anderen). Het perspectief van de school ontbreekt.

In deze presentatie is veel begrip voor het perspectief van de ouder. Het dilemma van de stagiaire/leerkracht 'Ik wil wel helpen, maar niet nu' wordt goed uitgewerkt. De stagiaire-leerkracht heeft als belangrijk doel 'De ouder moet met een fijn gevoel de klas uitgaan'. Ook wordt belang gehecht aan 'de zaak van twee kanten bekijken, een oplossing willen bieden' en wordt in dat verband het perspectief van de betrokken kinderen nadrukkelijk genoemd. De perspectieven van ouder, kind en stagiaire worden betrokken in de uiteindelijke oplossing van het probleem. Het volgende citaat verduidelijkt dit:

'We hebben dus gekozen voor de oplossing om na schooltijd verder te gaan praten en ook om met de jongens zelf in gesprek te gaan. En zoals de moeder in dit geval zelf ook zegt: Je hoort het verhaal uh alleen van haar zoontjes kant in dat geval. Dus om van allebei de kanten het verhaal te horen, draagt alleen maar bij aan de oplossing. En om na schooltijd in gesprek te gaan met de moeder, dan zorg je ervoor dat je weet wat er gebeurd is uit het verhaal van die jongens en je geeft die moeder dan ook aan wat er precies is gebeurd. En je gaat dan daarmee weer in gesprek met die moeder, met die uitslag daarvan'.

In de verklaring van het communicatieve gedrag van de stagiaire komt de verhouding tussen leerkracht en stagiaire uitgebreid aan de orde, waarbij het perspectief van de stagiaire de meeste aandacht krijgt.

\section{Geval 2 sterk}

In de presentatie worden expliciet de perspectieven van de leerkracht, de ouder en de school belicht. In de presentatie wordt veel begrip getoond voor de teleurstelling van de ouder die niet mag meehelpen met een activiteit. Inleving in het perspectief van de ouder vindt plaats. Een voorbeeld hiervan:

'Want het is natuurlijk niet leuk als je hoort ... als je heel graag wilt helpen, maar dat de school eigenlijk je hulp niet kan gebruiken.' 
Ook is de groep zich sterk bewust van het langetermijnbelang van de leerkracht die gebaat is bij ouderbetrokkenheid en behoud van de relatie. In de oplossing van het probleem worden het langetermijnbelang en de beleving van de ouder meegewogen. Verder heeft deze groep een duidelijk bewustzijn van het organisatieperspectief: de leerkracht is gecommitteerd aan de afspraken binnen de school/bestuur. Dat wordt bijvoorbeeld zo uitgedrukt:

'Loyaliteit, we hebben gekozen voor loyaliteit, want je hebt trouw zeg maar aan de verplichtingen die je van hogerop is gegeven, dus dat er geen ouders mogen helpen tijdens dit project zeg maar. En de leerkracht is daarbij trouw aan de afspraken die gemaakt worden of zijn met het bestuur. (...) En ook wat daarover afgesproken is tijdens de vergaderingen op school.'

\section{Geval 3 sterk}

In de presentatie is expliciet aandacht voor het perspectief van de ouder, de leerkracht en de school. De presentatie heeft een heldere, zich herhalende structuur waarbij steeds leerkrachtgedrag en oudergedrag worden verklaard. Het perspectief van de school wordt betrokken door de formulering van het beleidsdoel: respectvol omgaan met ouders en rust handhaven. Dit beleidsdoel wordt consequent betrokken bij de verklaring van het leerkrachtgedrag. Door deze aanpak wordt in de presentatie consequent begrip getoond voor verscheidene perspectieven op de communicatieve situatie.

Aandacht voor het perspectief van de ouder uit zich in een beschrijving van de oorzaak van het agressieve gedrag. Doordat de student zich inleeft in de oorzaak van emotionele agressie vanuit het perspectief van de ouder, toont zij begrip voor het gedrag van de ouder:

'En de kenmerken van de emotionele agressie, ja, het is een opeenvolging van negatieve ervaringen, want zijn zoon komt dus constant thuis met 'en de leerkracht dit en de leerkracht dat en die doet zus en die doet zo'. Dus het is niet alleen dit ene incident, maar die leerkracht doet volgens de zoon wel meer vervelende dingen. Dus dit is nog een voorbeeld van vervelende ervaringen, waardoor die vader zoiets heeft van de maat is vol, bah. [gelach]. Dus vandaar, dat hoort ook bij emotionele agressie.'

Het belang van de ouder en van de leerkracht wordt in de oplossing van het probleem meegenomen:

'(...) want je geeft eigenlijk de ouder ook een beetje zijn zin, dus je komt tegemoet aan ... omdat het kind naar een voetbalwedstrijd heen moet. De ouder is gekalmeerd door het uit te praten, tevens krijgt de leerling toch zijn straf en toch kan hij op tijd bij de voetbalwedstrijd zijn. Dus voor alle twee de partijen zit er winst.'

\section{Geval 4 zwak}

Het perspectief van de stagiaire-leerkracht is expliciet aanwezig, het perspectief van de ouder impliciet en dat van de school ontbreekt.

Het communicatieve dilemma, met de conflicterende belangen van ouder en leerkracht, komt niet goed uit de verf: de studenten zien het belang van de leerkracht niet (hoewel in de reflectie op het handelen wel blijk wordt gegeven van een 
beginnend inzicht hierin). Inhoudelijk is een goede oplossing voor het communicatieve probleem bedacht; de verantwoording is echter eenzijdig gericht op het respectvol met elkaar omgaan. Verscheidene keren wordt niet zozeer het verschillende perspectief of belang van ouder en leerkracht benoemd, maar vooral de respectvolle attitude van beide gesprekspartners. Impliciet getuigt dit wel van aandacht voor 'het verhaal van de ander'. Respect en begrip voor de ouder en goed luisteren, zijn belangrijke uitgangspunten voor de studenten. Daarmee wordt rekening gehouden in het communicatieve gedrag van de stagiaire-leerkracht:

'Ze laat de moeder dus ook heel veel uh aan het gesprek uh ja betrokken zeg maar. Ze laat duidelijk de stem van de moeder ook gelden; dat die ook belangrijk is en dat niet alleen de leerkracht beslist van dit gaat gebeuren. Enne .. ze leeft dus ook heel erg mee met de moeder. Dat kun je duidelijk zien, dat zij zich ook goed kan verplaatsen.'

\section{Geval 5 zwak}

De perspectieven en (tegenstrijdige) belangen van leerkracht, ouder en school worden expliciet meegewogen in de bespreking van het communicatieve probleem en de gekozen oplossing. Een ethische dimensie van het probleem wordt daarbij belicht: is een leugentje om bestwil geoorloofd?

Je. 'We wouden ja eerst eigenlijk, we hadden eerst eigenlijk gedacht om met een leugentje voor bestwil haar af te wijzen, maar ... ja ... dat hadden we toch niet gedaan, want we dachten ... we waren bang dat ze via via .. stel, het is een echte situatie ... dat ze er dan achter komt. En in een echte situatie, hadden we gezegd, zouden we dat niet aandurven, dus daarom deden we dat nu ook niet.

J. En sowieso denk ik ook dat je als school toch wil uitstralen dat je elke hulp kan gebruiken. En elke ouder ... je wil gewoon als school laagdrempelig zijn ... ik bedoel, elke ouder moet zo binnen kunnen lopen en wat kunnen vragen. Maar ook dat je gewoon kunt vertrouwen op hun hulp. En ik denk dat als je iemand toch uh afwijst ... als dat dan misschien rond zou gaan, dat zij dan, wat Jenny ook zei, er toch achter zou komen, dat het toch niet helemaal zo is als dat jij gezegd hebt, dat je daar dan toch ook voor jezelf een probleem mee krijgt en dat ouders misschien helemaal niet meer willen helpen. Ik denk dat je toch als doel moet hebben dat je beide partijen tevreden houdt en door op deze manier de ouder te informeren zo van wat het geval is, dat [onverstaanbaar] wat jouw situatie op dat moment is. Dat het voor de Pabo is en voor jou een belangrijk bezoek. En uh, ja, zij weet dan ook in principe wat er van haar verwacht wordt dus je speelt wel een beetje in op de situatie.'

Het perspectief en belang van leerkracht en school hebben de overhand, het perspectief van de ouder krijgt beperkt aandacht in de presentatie. Een voorbeeld hiervan is dat alleen het communicatieve doel van de leerkracht wordt beschreven, het perspectief of de beleving van de ouder ontbreekt. 


\section{Geval 6 zwak}

In de presentatie is expliciet aandacht voor het perspectief van de leerkracht. Voor de ouder wordt vooral empathie getoond en het belang van een goede relatie tussen ouder en leerkracht wordt genoemd. Impliciet getuigt dit wel van aandacht voor 'het verhaal van de ander'.

'Stap 7, positief afsluiten, dat ik de moeder toch nog even bedank dat ze toch wat rustiger is geworden en dat ik blij ben dat ze bij me is gekomen en dat het vervelend is als er zulke problemen tussen ouder en leerkracht in blijven staan. Voor de relatie is dat natuurlijk vervelend. De moeder gaat dan ook met een positief gevoel, naar mijn gevoel, weer weg, dus het is positief afgesloten.'

Voor het perspectief van de school is beperkt aandacht: Dit wordt wel genoemd, maar niet uitgewerkt. Ook het perspectief van het kind (relevante ander) wordt beperkt betrokken in de oplossing voor het probleem:

'En bij stap 6, nou, dan is de oplossing dat iedereen nog wel een tweede kans krijgt, maar dat het dus verkeerd is begrepen. En dat ik dan zelf nog even met het kind praat de volgende dag om voortaan zulke misverstanden te voorkomen, omdat het gewoon erg vervelend is.'

\subsubsection{Duiding van alle gevallen ${ }^{12}$}

Het aantal perspectieven dat wordt betrokken bij de communicatieve situatie en de manier waarop dat gebeurt laat enkele patronen zien. In alle presentaties wordt het perspectief van de leerkracht/stagiaire expliciet benoemd en uitgebreid uitgewerkt. Het perspectief van de ouder wordt ook in alle gevallen ingenomen, maar niet in alle gevallen expliciet en uitgebreid; geval 1, 2 en 3 geven meer inhoud aan het ouderperspectief dan geval 4, 5 en 6 .

Het perspectief van de school dat verder afligt van de directe communicatieve situatie, wordt in vier presentaties (geval 2, 3, 5 en 6) expliciet ingenomen, wat getuigt van een zeker organisatiebewustzijn. In drie presentaties is dit schoolperspectief uitgebreid belicht. In geval 5 bijvoorbeeld wordt het communicatieve probleem expliciet vanuit de drie invalshoeken van leerkracht, schoolorganisatie en ouder bekeken en worden ethische afwegingen worden gemaakt in het zoeken naar een passende oplossing. Het schoolperspectief ontbreekt in twee presentaties (geval 1 en 4). Ten slotte wordt in twee presentaties het perspectief van de leerlingen die betrokken zijn bij de communicatieve situatie, expliciet genoemd. In geval 1 gebeurt dit uitgebreid en in geval 6 is dit perspectief inhoudelijk beperkt uitgewerkt.

Gemeenschappelijk in alle presentaties is een respectvolle, begripvolle en empathische attitude tegenover ouders, een gerichtheid op het behoud van een goede relatie met de ouder en een besef van het belang van ouderbetrokkenheid voor de school. Ook wordt in alle presentaties een constructieve oplossing voor het communicatieve probleem gevonden.

12 In deze paragraaf worden de resultaten van sterke en zwakke gevallen niet apart weergegeven. Zie voor verantwoording paragraaf 6.5. 
In de gevallen 1, 2, 3 en 5 worden drie perspectieven expliciet benoemd en uitgebreid toegelicht. Het innemen van verschillende perspectieven op de communicatieve situatie blijkt uit enkele inhoudelijke elementen van de presentaties:

- Leerkrachtgedrag wordt toegelicht vanuit uitgesproken begrip voor de situatie van ouder;

- Leerkrachtgedrag wordt toegelicht vanuit een uitgesproken besef van het belang van ouderbetrokkenheid en behoud van de relatie;

- Een voor alle betrokken partijen bevredigende oplossing van het probleem wordt expliciet gezocht.

In de gevallen 4 en 6 worden respectievelijk twee en vier perspectieven ingenomen en is de inhoudelijke uitwerking daarvan beperkter. De motivatie voor het leerkrachtgedrag en voor het zoeken van een bevredigende oplossing van het probleem gebeurt in deze gevallen impliciet.

Samengevat: In alle presentaties wordt vanuit verschillende invalshoeken het communicatieve probleem belicht. Daarnaast wordt een constructieve oplossing voor het probleem gezocht, worden ouders positief benaderd en wordt een goede relatie met ouders nagestreefd.

Verschillend is de mate van articulatie waarmee deze elementen worden betrokken in de toelichting. In vier presentaties worden deze elementen expliciet geformuleerd als onderbouwing voor het leerkrachtgedrag, in twee presentaties liggen deze elementen wel ten grondslag aan het leerkrachtgedrag, maar blijven ze impliciet.

\subsubsection{Conclusie}

De zes presentaties laten voor het innemen van diverse perspectieven op het communicatieve probleem het volgende beeld zien:

1. In alle presentaties wordt de communicatieve situatie vanuit meerdere perspectieven belicht en wordt een voor alle partijen bevredigende oplossing van het probleem gezocht. De mate waarin en de wijze waarop studenten verschillende perspectieven betrekken in hun probleemanalyse en oplossing verschillen wel.

2. De perspectieven van leerkracht en ouder wordt inhoudelijk het meest uitgewerkt, ook het perspectief van de school wordt in vier gevallen betrokken.

3. Gemeenschappelijk in de presentaties is een positieve, constructieve en begripvolle attitude tegenover ouders en een gerichtheid op het behoud van een goede relatie tussen ouder en leerkracht. 


\subsection{Conclusie en discussie}

In deze studie is nagegaan hoe en met welke kwaliteit de cognitieve flexibiliteit van studenten zich in de tweede fase van het ontwerp manifesteert. Wat betekenen de resultaten nu voor de ontwikkeling en de kwaliteit van de cognitieve flexibiliteit? Hoe ver zijn de studenten op weg?

\section{Conceptgebruik in toelichting}

In de sterke gevallen is de conceptuele structuur goed ontwikkeld en krijgt het betekenis voor het professioneel handelen. Studenten hanteren de conceptuele structuur adequaat in de toelichting op professioneel handelen met een duidelijke tendens naar verklaring van dat gedrag. Consequent worden de concepten geconcretiseerd en verbonden aan voorbeelden van professioneel handelen in de videobeelden. In zoverre ontwikkelt dit aspect van cognitieve flexibiliteit zich positief. In de zwakke gevallen wordt de conceptuele structuur ook toegepast om het professioneel handelen te beschrijven en te verklaren; in de basis zijn deze studenten echter minder ver, omdat de conceptuele structuur onvolledig wordt beheerst, deze hiaten en/of fouten bevat, en omdat de relatie met het eigen handelen minder concreet en consequent wordt gelegd.

Studenten nemen behalve opdrachtgestuurde concepten ook spontaan begrippen op in de toelichting. Zowel in de zwakke als sterke gevallen beperken de studenten zich niet tot de strikte aard van de opdracht. De veronderstelling naar aanleiding van studie 1 dat concepten vooral in sterke presentaties spontaan zouden worden geïntegreerd en in zwakke niet, blijkt onjuist. De wijze waarop concepten spontaan worden opgenomen in de toelichting bevestigt het beeld van de verschillen tussen sterke en zwakke gevallen. In de sterke gevallen is het spontane conceptgebruik adequater en meer verbonden aan het eigen handelen.

Met betrekking tot het niveau waarop de conceptuele structuur is toegepast, is opgevallen dat de kwaliteit van de redeneringen voor verbetering vatbaar is. In de sterke gevallen komt een expliciet redenerend verband wel voor, maar vaak blijven, overigens binnen een inhoudelijk correct betoog, de redenerende verbanden impliciet. Het is een vraag of deze impliciete wijze van redeneren samenhangt met de mondelinge aard van de toelichting (en dat van de toehoorders verwacht wordt dat de verbanden wel worden begrepen) - of dat de studenten hierin meer oefening en ondersteuning behoeven. In het onderwijsarrangement en in de beoordelingscriteria wordt niet expliciet aandacht besteed aan redeneren en argumenteren en dit kan een omissie zijn. Het leggen van expliciete verbanden tussen concepten vraagt echter wel een groot redenerend vermogen, wat in deze fase van de interventie misschien een te hoge verwachting is. Om de kwaliteit van de redeneringen te verhogen is het expliciteren van logische verbanden een punt dat in de volgende fasen van de interventie aandacht behoeft. 


\section{Conceptgebruik in reflectie}

Ook in de reflectie op het handelen worden in alle gevallen spontaan concepten gehanteerd. Een doelstelling van de interventie is het bevorderen van een professioneel discours onder leraren. De resultaten geven een aanwijzing dat een eerste stap in die richting wordt gezet in deze fase van de interventie. In één sterk geval vindt tijdens de reflectie bovendien transfer plaats: met behulp van een concept wordt gereflecteerd op een ervaring in de beroepspraktijk (stage). Deze vorm van cognitieve flexibiliteit behoort tot de beoogde einddoelen van de interventie.

Het spontaan gebruik van concepten in de reflectie vormt, net als het spontaan gebruik in de toelichting, een aanwijzing dat studenten zich de conceptuele structuur eigen weten te maken en hun professioneel handelen beginnen te verantwoorden met behulp van concepten. Hierbij kan worden opgemerkt dat nog niet alle studenten dit doen en dat de reflectie zich in een aantal gevallen nog beperkt tot het professioneel handelen in de videobeelden.

\section{Perspectieven innemen}

Behalve de toepassing van de conceptuele structuur, is het innemen van verschillende perspectieven op de communicatieve situatie een aspect van cognitieve flexibiliteit. De bevindingen laten zien dat een deel van de studenten goede resultaten boekt op dit aspect en dat een ander deel van de studenten hierin achterblijft. Verschillen liggen niet eenduidig tussen sterke en zwakke gevallen. In vier gevallen worden expliciet en uitgebreid verschillende perspectieven betrokken en belangen afgewogen; in drie gevallen wordt hierbij ook het organisatieperspectief, dat het verst afligt van de communicatieve situatie zelf, betrokken. Dit beginnend organisatiebewustzijn wordt in deze fase van de interventie beschouwd als een positief signaal. In de volgende fase van de interventie is namelijk pas sprake van een authentieke situatie, wat studenten in staat stelt daadwerkelijk informatie te verzamelen over het perspectief van de school.

In twee (zwakke) gevallen is het leerkrachtperspectief dominant en zijn andere perspectieven impliciet of expliciet maar beperkt meegewogen. In deze gevallen vergt het expliciet benoemen van perspectieven en deze inhoudelijk zinvol betrekken op de communicatieve situatie nog aandacht. Alle gevallen worden ten slotte gekenmerkt door een empathische, constructieve en respectvolle houding jegens ouders.

\section{Verantwoording van vervolganalyse}

In deze studie is gepoogd inzicht te verwerven in de zich ontwikkelende cognitieve flexibiliteit van studenten. Daartoe is onder andere onderzocht met welke kwaliteit de conceptuele structuur door studenten wordt gehanteerd (§ 6.6.1 en 6.6.2). In de studie is een deductieve aanpak gehanteerd voor het onderzoeken van de aspecten aard en niveau van het conceptgebruik. Deze aanpak levert inzichten op in de manier waarop studenten de conceptuele structuur gebruiken, maar kent ook beperkingen. Tijdens de analyse van de sterke gevallen is opgemerkt dat elementen die wel indicatief lijken voor cognitieve flexibiliteit geen plaats krijgen in de analyse. In één presentatie bijvoorbeeld worden concepten herhaaldelijk toegepast op verschillende 
videofragmenten van leerkrachtgedrag. Studenten tonen hiermee aan dat ze concepten op verschillende situaties kunnen toepassen, een aspect van cognitieve flexibiliteit. Dergelijke observaties hebben geen plaats gekregen in de analyse, maar geven wel een genuanceerd inzicht in de manier waarop studenten de conceptuele structuur hanteren. Om recht te doen aan de data en een diepgaander beeld te verkrijgen van de wijze waarop cognitieve flexibiliteit zich manifesteert, worden de data in een vervolganalyse op een inductieve wijze benaderd (Glaser \& Strauss, 1967; Henry, 2012).

\subsection{Nadere data-analyse van kwaliteitsbevorderende elementen}

\subsubsection{Onderzoeksmethode studie $\mathbf{2 b}$}

\section{Onderzoeksvraag}

In deze aanvullende studie wordt gezocht naar een nadere invulling van het begrip cognitieve flexibiliteit. Onderzocht wordt welke andere elementen dan benoemd in studie 2a bevorderend zijn voor de kwaliteit waarmee de conceptuele structuur gebruikt. De onderzoeksvraag hierbij is: Welke kwaliteitsbevorderende elementen van cognitieve flexibiliteit tonen studenten in het gebruik van de conceptuele structuur bij de toelichting op videobeelden van eigen professioneel handelen? Het doel hiervan is om een genuanceerd beeld te verkrijgen van de manier waarop cognitieve flexibiliteit zich manifesteert en zo een bijdrage te leveren aan de specificering van het begrip.

\section{Data-analyse}

Voor deze derde onderzoeksvraag is een interpretatieve werkwijze gehanteerd. Bij de analyse van drie sterke presentaties houdt de onderzoeker een open oog voor de manier waarop de conceptuele structuur wordt gehanteerd in de presentatie. Opvallende aspecten waaruit blijkt dat concepten adequaat worden gehanteerd worden genoteerd. Op basis van deze notities is beargumenteerd in hoeverre de opvallende aspecten daadwerkelijk geïnterpreteerd kunnen worden als uitingen van cognitieve flexibiliteit en de kwaliteit van de getoonde cognitieve flexibiliteit verhogen.

\subsubsection{Resultaten}

\section{Geval 1 sterk}

De presentatie bevat twee kwaliteitsbevorderende elementen.

- Twee aspecten van cognitieve flexibiliteit worden herhaaldelijk gecombineerd: de toepassing van concepten op verschillende situaties en het innemen van verschillende perspectieven.

De presentatie bevat videobeelden van ouder- en leerkrachtgedrag; deze fragmenten kunnen worden beschouwd als verschillende communicatieve situaties; bij alle 
videofragmenten worden het communicatieve doel, de expressieve en de relationele boodschap geanalyseerd. Deze aanpak maakt duidelijk dat de studenten het perspectief van leerkracht en van de ouder innemen én dat zij concepten op verschillende situaties kunnen toepassen. De combinatie van de herhaalde toepassing van concepten op videofragmenten van ouder- en leerkrachtgedrag, geeft diepgang aan de getoonde cognitieve flexibiliteit.

- Het verband tussen doel, middel (gespreksvaardigheden) en effect wordt herhaaldelijk adequaat geëxpliciteerd en geillustreerd met concrete eigen videobeelden.

In deze presentatie wordt bij twee videofragmenten van de concepten 'relationele en expressieve boodschap' uitgelegd wat de boodschap is, hoe deze vorm krijgt door bepaalde gespreksvaardigheden toe te passen en wat het bedoelde effect ervan is. Hiermee vindt de concretisering van abstracte begrippen in zichtbaar communicatief gedrag plaats, een uiting van cognitieve flexibiliteit. Een voorbeeld hiervan:

‘Expressieve boodschap: Het leerkrachtgedrag straalt rust uit (doel) (...). Het stemgebruik was dan heel rustig (middel), dat is dan verbaal, om aan te geven dat je wel de tijd neemt voor die moeder (effect). Lichaamshouding was ook open (middel), en uhm, hier liet ze ook de pen, ik legde de pen weg (middel) om aan te geven dat ik tijd nam voor die moeder, dat ik er tijd voor had om even te luisteren (effect). Ik ging ook open staan (middel), zo van, laat maar zien wat er aan de hand is (effect).'

\section{Geval 2 sterk}

Deze presentatie bevat drie kwaliteitsbevorderende elementen:

- Spontaan gehanteerde concepten worden herhaaldelijk op verschillende situaties toegepast.

In de toelichting worden de concepten 'appellerende, relationele en expressieve boodschap' spontaan gehanteerd, want ze behoren niet tot de opdrachtgestuurde concepten. Deze concepten worden herhaaldelijk toegepast op verschillende videofragmenten van leerkrachtgedrag (beschouwd als situaties). Studenten tonen hiermee aan dat ze concepten spontaan op verschillende situaties kunnen toepassen, een aspect van cognitieve flexibiliteit.

- De 'verschijningsvormen' van een concept worden vergeleken.

Een korte vergelijking vindt plaats van de expressieve boodschap van twee studenten.

'De expressieve boodschap, ik vond hem bij Jennifer best wel heel erg zeker. Jennifer komt heel ... ze straalt wel overtuigingskracht uit en lijkt wel heel zeker van haar zaak. Ik vind dat je een beetje verschil kan zien met Carien, die komt toch iets meer onzeker over en Jennifer is wat zekerder in dit geval'.

Hiermee laten studenten zien dat zij inzien dat dit begrip op verschillende manieren invulling kan krijgen in concrete situaties, een aspect van cognitieve flexibiliteit. Een impliciete waardering van de verschillende 'invullingen' wordt gegeven.

- Twee concepten (communicatief doel en gespreksvaardigheden) worden uitgebreid toegelicht met subconcepten en selectief toegepast op de situatie. 
Kennis hebben van de conceptuele structuur, maar vooral een bewuste keuze maken in de toepassing ervan, laat zien dat de concepten met gevoel voor de specifieke context worden toegepast. Dit is een uiting van cognitieve flexibiliteit.

- Transfer van een concept naar een situatie in de beroepspraktijk vindt plaats.

Eén student reflecteert met behulp van een concept op een ervaring in de beroepspraktijk (zie paragraaf 6.6.2). Transfer van concepten naar andere situaties is het doel van cognitieve flexibiliteit.

\section{Geval 3 sterk}

Deze presentatie bevat vier kwaliteitsbevorderende elementen.

- Concepten worden herhaaldelijk op verschillende situaties toegepast .

Bij alle videofragmenten wordt het leerkrachtgedrag verklaard in relatie tot het beleidsdoel van de school en wordt het oudergedrag verklaard met behulp van kennis over agressief gedrag. Door deze aanpak worden in de presentatie enkele concepten herhaaldelijk toegepast en in verband met elkaar gebracht (zie paragraaf 6.6.3).

- Het verband tussen doel, middel en bedoeld effect wordt herhaaldelijk adequaat geëxpliciteerd en geïllustreerd met concrete eigen videobeelden.

In deze presentatie wordt in alle videofragmenten inhoud gegeven aan de concepten 'beleidsdoel en communicatieve doel', wordt verhelderd met welke gespreksvaardigheden daaraan wordt vormgegeven en welk bedoeld effect wordt beoogd. Een voorbeeld hiervan:

'Het beleidsdoel van de school met betrekking tot de agressieve ouder is respect, je respecteert wat de ouder zegt. En dat hij naar je toekomt. Je respecteert zijn verhaal. Rust handhaven (doel), is dat de ouder naar jou toe komt en je zegt: Doe even rustig, we zoeken even een ander plekje op (middel), dat we rustig kunnen praten zonder dat er kinderen bij zijn en zonder dat er andere ouders bij zijn, anders krijg je weer van 'blabla (effect)'.

Hier is sprake van cognitieve flexibiliteit, omdat abstracte begrippen geconcretiseerd worden in zichtbaar communicatief gedrag.

- Er is afwisseling van aandacht voor concrete details en abstractie.

In de presentatie tonen studenten aandacht voor de praktische details en concrete situatie waarin ze moeten handelen. Het beleidsdoel 'rust handhaven' bijvoorbeeld wordt omgezet in een handelingsvoorschrift (andere leerkracht op de hoogte brengen) met aandacht voor de praktische uitvoering.

'Wat je hier ziet is het beleidsdoel van de school, hoe je dan omgaat met agressieve ouders, is uh ... ook een andere leerkracht op de hoogte stellen, zodat je dus niet zonder dat iemand anders daarvan op de hoogte is, dat je daar zit in een kamertje met zo'n boze ouder, daar kan van alles en nog wat gebeuren .. dus het beleid is van ... vertel dat aan iemand anders, in dit geval de directeur, want ten eerste moest er in dit geval ook even vervanging geregeld worden om de klas op te vangen voor het geval zij niet op tijd terug zou zijn en dat dus iemand weet dat zij daar met een ouder in gesprek is.' 
Tegelijkertijd blijken de studenten in staat om in een kort bestek (onder enige tijdsdruk) verbanden te leggen tussen diverse concepten en de getoonde videobeelden, waaruit blijkt dat de concepten een concrete invulling voor de student hebben zonder dat op ieder detail wordt ingegaan. De wisselwerking tussen concrete situatiegebonden details en het gebruik van algemene concepten is een uiting van cognitieve flexibiliteit.

'En dan nog even kort naar de onderwijscontext. In het filmpje zag je loyaliteit terug. De leerkracht houdt zich aan het beleidsdoel van de school, dus hij is er trouw aan. Deskundigheid: de leerkrachten weten hoe ze moeten handelen, ze kennen het stappenplan, positief afsluiten, tussendoor begrip tonen et cetera. En verantwoordelijkheid voor een veilige omgeving voor de leerlingen. Dus een aparte ruimte zoeken. En natuurlijk zijn eigen veiligheid door even iemand op de hoogte te stellen.

\subsubsection{Vergelijking en conclusie}

In elk van de sterke presentaties zijn diverse elementen gevonden die de kwaliteit van het conceptgebruik verhogen. Een gemeenschappelijk element is de herhaalde toepassing van concepten op verschillende situaties. Eén element komt in twee presentaties voor en de overige zijn uniek voor een bepaalde presentatie. In Tabel 6.8 zijn de resultaten weergegeven.

Tabel 6.8 Overzicht van kwaliteitsbevorderende elementen in de sterke gevallen

\begin{tabular}{l|l|l|l} 
Kwaliteitsbevorderend element & Geval 1 & Geval 2 & Geval 3 \\
\hline $\begin{array}{l}\text { Herhaalde toepassing van concepten op verschillende } \\
\text { situaties (ook spontaan gehanteerde concepten of in } \\
\text { combinatie met het innemen van verschillende } \\
\text { perspectieven) }\end{array}$ & $\mathrm{X}$ & $\mathrm{X}$ & $\mathrm{X}$ \\
\hline $\begin{array}{l}\text { Concretisering van concept door herhaaldelijke } \\
\text { adequate explicitering van doel, middel en effect en } \\
\text { illustratie met concrete voorbeelden }\end{array}$ & $\mathrm{X}$ & & $\mathrm{X}$ \\
\hline Transfer van concept naar beroepspraktijk & & $\mathrm{X}$ & \\
\hline Afwisseling van situatiegebonden details en concepten & & & $\mathrm{X}$ \\
\hline $\begin{array}{l}\text { Expliciete vergelijking van verschillende } \\
\text { verschijningsvormen van een concept }\end{array}$ & & $\mathrm{X}$ & \\
\hline $\begin{array}{l}\text { Uitgebreide toelichting van concepten met } \\
\text { subconcepten en selectieve toepassing op situatie }\end{array}$ & & $\mathrm{X}$ &
\end{tabular}

De sterke presentaties bevatten ieder een vorm van herhaling die een bijdrage levert aan de kwaliteit waarmee de concepten worden gehanteerd. Bepaalde concepten worden herhaaldelijk toegepast op verschillende videofragmenten, wat leidt tot een verdieping van het begrip van de communicatieve situatie. Met deze aanpak tonen studenten een diep begrip van de gehanteerde concepten. In alle gevallen wordt de herhaalde toepassing van concepten bovendien gecombineerd met een ander sterk 
element: In geval 1 wordt met deze aanpak aandacht besteed aan de perspectieven van leerkracht en ouder, in geval 2 betreft het spontaan toegevoegde concepten en in geval 3 wordt aandacht besteed aan de perspectieven van leerkracht, ouder en school.

Een tweede element dat de kwaliteit van het conceptgebruik bevordert, is te vinden in twee presentaties. Daarin wordt een aantal concepten opvallend goed geconcretiseerd door het verband tussen doel, middel (gespreksvaardigheden) en effect adequaat te expliciteren en te illustreren met concrete voorbeelden. Een dergelijke expliciete redenering - 'Ik wil $\mathrm{X}$ bereiken, daarom doe ik $\mathrm{Y}$ en dat leidt tot $\mathrm{Z}$ bij de ouder'- getuigt van het bewust en doelgericht inzetten van professioneel gedrag en van het concretiseren van een abstract begrip in een specifieke context.

De overige kwaliteitsbevorderende elementen doen zich eenmalig voor en dragen, in een context die al gekenmerkt wordt door positieve indicaties, bij aan het verhogen van de getoonde cognitieve flexibiliteit.

\section{Conclusies}

1. De analyse levert een nadere invulling van het begrip cognitieve flexibiliteit op. Een diep begrip van concepten wordt getoond door herhaaldelijke toepassing of concretisering van die concepten in verschillende situaties. Daarnaast wordt een diep begrip van enkele concepten getoond door transfer, vergelijking, uitgebreid gebruik van subconcepten en pendelen tussen concept en situatiegebonden details.

2. De sterke presentaties bevatten ieder een unieke combinatie van elementen die de kwaliteit waarmee concepten worden gehanteerd, bevordert.

Een gemeenschappelijke element in de sterke presentaties is dat concepten herhaaldelijk worden toegepast of geconcretiseerd in verschillende situaties. Ook bevat elke sterke presentatie nog een aantal andere kwaliteitsbevorderende elementen in een unieke combinatie. Studenten tonen hiermee een zekere wendbaarheid in de toepassing van concepten. De herhaaldelijke toepassing van concepten wijst op een diepe verwerking van concepten en op vertrouwdheid met de concepten; de andere elementen die zich incidenteel voordoen, wijzen ook in die richting.

In deze studie is de herhaalde toepassing van concepten op verschillende situaties gekarakteriseerd als kwaliteitsbevorderend element. In deze context heeft het begrip 'situatie' betrekking op verschillende fragmenten van hetzelfde gesprek. Er is dus geen sprake van een volstrekt andere communicatieve situatie; de verschillende situaties liggen nog dicht bij elkaar. Daarmee heeft het begrip 'situatie' een beperkte reikwijdte en van transfer wordt dan ook nog niet gesproken. 


\subsection{Slotconclusie en discussie}

In deze paragraaf worden de conclusies van het voorgaande onderzoek gerecapituleerd en worden ze bediscussieerd.

In dit hoofdstuk is onderzocht hoe cognitieve flexibiliteit zich in een vroeg stadium van de interventie manifesteert en daartoe zijn twee studies uitgevoerd. De leerdoelen in dit stadium zijn gericht op twee aspecten van cognitieve flexibiliteit, namelijk het gebruik van de conceptuele structuur en het innemen van diverse perspectieven.

1. In de eerste kwantitatieve studie is onderzocht in hoeverre studenten concepten hanteren bij de mondelinge toelichting op videobeelden van eigen professioneel handelen. De resultaten laten zien dat aan een belangrijke voorwaarde voor de ontwikkeling van cognitieve flexibiliteit is voldaan: studenten hanteren de conceptuele structuur. Ook nemen studenten spontaan (dat wil zeggen, niet door de opdracht gestuurd) concepten op in hun toelichting wat erop wijst dat zij zich de conceptuele structuur eigen beginnen te maken. Daarnaast heeft studie 1 een genuanceerd beeld opgeleverd van welke concepten meer en minder frequent worden gehanteerd.

In de tweede studie stond de vraag centraal naar de wijze waarop cognitieve flexibiliteit zich manifesteert om inzicht te krijgen in de ontwikkeling ervan. In deze kwalitatieve studie is onderzocht met welke kwaliteit de conceptuele structuur door studenten wordt gehanteerd in de toelichting en de reflectie op het professioneel handelen. Daarnaast is nagegaan welke perspectieven studenten betrekken bij de toelichting op hun professioneel handelen en hoe zij dit uitwerken. Op grond van de studie rijst een rijkgeschakeerd beeld op van een zich ontwikkelende cognitieve flexibiliteit in een vroege fase van de interventie.

2. Met betrekking tot de vraag hoe en met welke kwaliteit studenten conceptuele ennis gebruiken in de toelichting op hun handelen wordt het volgende geconcludeerd.

Aan de ene kant van het spectrum bevindt zich een groep studenten die uitstekend slaagt in de adequate interpretatie en toepassing van de eerder geleerde conceptuele structuur. Deze studenten hanteren de concepten met een duidelijke tendens naar verklaring van hun professioneel handelen.

De beheersing van de conceptuele structuur komt op verschillende manieren tot uitdrukking. De studenten weten betekenis te geven aan de concepten door consequent een concrete relatie te leggen met het professioneel handelen. Ook worden concepten spontaan in de toelichting op het handelen geïntegreerd, waarbij ze juist worden geïnterpreteerd en verbonden aan het handelen. Dit spontane en adequate gebruik van concepten duidt op een zekere vertrouwdheid met de conceptuele structuur. 
De resultaten van studie $2 b$ laten bovendien zien dat de kwaliteit waarmee de conceptuele structuur wordt gebruikt, wordt versterkt door elementen die duiden op een diep begrip van concepten en een zekere wendbaarheid in de toepassing ervan. Herhaaldelijke toepassing en concretisering van concepten in verschillende situaties is een gemeenschappelijk kwaliteitsbevorderend element in de presentaties; daarnaast komen, in een unieke combinatie, ook transfer, vergelijking, uitgebreid gebruik van subconcepten en pendelen tussen concept en situatiegebonden details voor. Kortom, de adequate interpretatie van opdrachtgestuurde en spontaan gehanteerde concepten, de concrete relatie met het professioneel handelen en de inzet van verscheidene kwaliteitsbevorderende elementen duiden op een goede beheersing van de conceptuele structuur.

Aan de andere kant van het spectrum bevindt zich een groep studenten bij wie de toepassing van de conceptuele structuur sterke en zwakke kanten kent. De conceptuele structuur dient om het professioneel handelen te beschrijven en te verklaren. Ook nemen deze studenten spontaan concepten op in hun toelichting op het handelen wat getuigt van een zekere vertrouwdheid met de conceptuele structuur. De kwaliteit van het conceptgebruik is echter in het geheel minder goed, omdat de conceptuele structuur onvolledig of deels onjuist wordt toegepast en omdat de relatie met het eigen handelen minder concreet en consequent wordt gelegd.

3. Met betrekking tot de vraag welke perspectieven studenten innemen in de toelichting op hun handelen en welke uitwerking zij hieraan geven, worden de volgende conclusies getrokken.

In alle presentaties worden verscheidene perspectieven op de communicatieve situatie ingenomen en wordt een voor alle partijen bevredigende oplossing voor het communicatieve probleem gevonden. De perspectieven van ouder en leerkracht worden steeds ingenomen en inhoudelijk het meest uitgewerkt. Ook wordt het perspectief van de school in vier presentaties betrokken. Het feit dat studenten het organisatieperspectief (dat het verst afligt van de communicatieve situatie zelf), betrekken in hun toelichting getuigt van een beginnend organisatiebewustzijn en wordt in deze fase van de interventie beschouwd als een positief signaal.

Verschillen zijn opgemerkt in de kwaliteit waarmee de verscheidene perspectieven worden uitgewerkt. Deze verschillen liggen niet eenduidig tussen de sterke en zwakke gevallen. Aan de ene kant van het spectrum worden expliciet en uitgebreid diverse perspectieven ingenomen en worden de belangen van diverse betrokken partijen afgewogen. Aan de andere kant van het spectrum worden weliswaar ook diverse perspectieven op de communicatieve situatie ingenomen, maar is de uitwerking ervan veelal impliciet en inhoudelijk beperkt.

Een empathische, constructieve en respectvolle houding ten slotte, en een gerichtheid op het behoud van een goede relatie tussen ouder en leerkracht, zijn typerend voor de manier waarop ouders worden bejegend. 
De combinatie van verschillende goed ontwikkelde aspecten van cognitieve flexibiliteit - de adequate toepassing van de conceptuele structuur, de inzet van kwaliteitsbevorderende elementen en het expliciet en uitgebreid innemen van diverse perspectieven - geeft samenhang en diepgang aan de toelichting op de communicatieve situatie en het professioneel handelen daarin. Dit wordt in de sterke gevallen getoond. Als een van de aspecten minder goed is ontwikkeld, zoals in de drie zwakke gevallen, heeft dit negatieve gevolgen voor de diepgang van en samenhang in de toelichting op het handelen.

4. Met betrekking tot de vraag hoe en met welke kwaliteit studenten conceptuele kennis gebruiken in de reflectie op het handelen wordt het volgende geconcludeerd. Concepten worden spontaan gehanteerd in alle reflecties. In alle gevallen wordt gereflecteerd op het handelen in de situatie in de videobeelden. Opgevallen is dat de reflectie in twee gevallen werd verbreed naar het handelen in de beroepspraktijk en dat in één geval hierbij zelfs transfer plaatsvond: de ervaring in de beroepspraktijk werd beschreven met behulp van een concept. Deze vorm van cognitieve flexibiliteit behoort tot de beoogde einddoelen van de interventie. Een doelstelling van de interventie is het bevorderen van een professioneel discours onder leraren. De resultaten geven een aanwijzing dat een eerste stap in die richting wordt gezet in deze fase van de interventie. Het spontaan gebruik van concepten in de reflectie vormt, net als het spontaan gebruik in de toelichting, een aanwijzing dat studenten zich de conceptuele structuur eigen weten te maken en hun professioneel handelen beginnen te verantwoorden met behulp van concepten.

\section{Discussie}

De conclusies over de ontwikkeling van cognitieve flexibiliteit werpen de vraag op of in deze fase van de interventie voor alle studenten al gesproken kan worden van advanced learning (cf. cognitieve flexibiliteitstheorie) of dat hier sprake is van een soort tussenfase tussen introductory en advanced learning.

Typerend voor introductory learning in een ill-structured domein is dat de conceptuele structuur van en denkwijzen binnen een domein worden geïntroduceerd aan de hand van niet al te ingewikkelde situaties; in de daaropvolgende fase van advanced learning komen de details en complexiteiten aan de orde waarbij kennis van de conceptuele structuur als voorwaardelijk wordt beschouwd. De resultaten uit deze studie laten zien dat een deel van de studenten aan deze voorwaarde voldoet; zij bevinden zich in het stadium van advanced learning. Niet voor alle studenten is de volledige beheersing en een betekenisvolle toepassing van de conceptuele structuur echter een gegeven. Voor deze studenten is het daarom passender nog niet te spreken van advanced learning, maar van een tussenfase tussen introductory en advanced learning, waarin de beheersing van de conceptuele structuur nog tot stand komt. 


\section{Hoofdstuk 7}

\section{Bereikte cognitieve flexibiliteit}

\section{Inleiding}

In dit hoofdstuk wordt verslag gedaan van de effectevaluatie van het vierde en laatste onderwijsarrangement. Het doel van de studie is te exploreren op welke wijze cognitieve flexibiliteit zich manifesteert in het eindstadium van de interventie. De hoofdmoot van dit hoofdstuk bestaat uit een meervoudige gevalsstudie waarin eindproducten van studenten worden geanalyseerd om inzicht te krijgen in de manifestatie van cognitieve flexibiliteit.

Kenmerkend voor cognitieve flexibiliteit is (a) de onderbouwing van professioneel handelen in realistische situaties met behulp van een conceptuele structuur, waarbij (b) het innemen van verschillende perspectieven en (c) situatiespecifieke factoren uit de context worden betrokken (zie hoofdstuk 3). Deze drie elementen vormen in samenhang de basis voor een verantwoording door de student van zijn professioneel handelen in een communicatieve situatie. In voorgaande onderwijsarrangementen lag het accent van de leerdoelen op twee van de drie elementen. In onderwijsarrangement 4 behoort ook het derde element, het betrekken van specifieke contextfactoren in de verantwoording van het handelen, tot de leerdoelen. Dat wordt mogelijk gemaakt doordat in onderwijsarrangement 4 een authentieke situatie centraal staat: studenten voeren een gesprek met ouders in de basisschool. Vanwege deze authentieke situatie zijn studenten daadwerkelijk in de gelegenheid om specifieke contextinformatie te vergaren (anders dan bij de geproduceerde videocases in de vorige arrangementen) en deze te betrekken in de verantwoording van hun professioneel handelen.

In lijn met de opbouw van de interventie wordt in deze studie onderzocht hoe de drie elementen van cognitieve flexibiliteit worden betrokken in de verantwoording van professioneel handelen. Nagegaan wordt in hoeverre studenten situatiespecifieke informatie en concepten verbinden in de onderbouwing van hun professioneel handelen in een authentieke situatie én in hoeverre zij de perspectieven van ouder en school daarin betrekken.

In dit hoofdstuk wordt ook een tweede, aanvullende studie gepresenteerd. Het ontwerp heeft naast het ontwikkelen van cognitieve flexibiliteit als nevendoelstelling professioneel taalgebruik onder leraren te bevorderen. In dit hoofdstuk wordt daarom onderzocht in hoeverre studenten concepten hanteren in een mondelinge taak met een informeel karakter. Deze studie sluit aan op (de tweede studie in) hoofdstuk 6 waarin het spontaan gebruik van concepten in een reflectie op communicatieve vaardigheden is onderzocht. 
Het hoofdstuk is als volgt opgebouwd: In paragraaf 7.1 wordt eerst de opzet van het onderwijsarrangement beschreven. Daarna wordt in paragraaf 7.2 tot en met 7.4 de eerste studie beschreven. Achtereenvolgens komen in die paragrafen de onderzoeksmethode, de resultaten en de conclusies aan de orde. In paragraaf 7.5 tot en met 7.7 wordt de tweede studie gepresenteerd volgens eenzelfde opzet.

\subsection{De interventie: onderwijsarrangement 4}

Het vierde onderwijsarrangement is bedoeld voor vierdejaars Pabo-studenten die de voorgaande drie onderwijsarrangementen hebben doorlopen en nu als leraar-inopleiding stage lopen in de basisschool. Tijdens deze afstudeerstage dragen zij medeverantwoordelijkheid voor het onderwijs van een groep leerlingen en onderhouden zij ook contacten met ouders. Het onderwijsarrangement bestaat uit twee plenaire bijeenkomsten van drie uur en het maken van een eindproduct. Tussen beide bijeenkomsten zit twee maanden tijd waarin de studenten werken aan een opdracht in de beroepspraktijk. De eerste bijeenkomst wordt besteed aan het trainen van communicatieve vaardigheden met een acteur, de tweede aan de analyse van een videocasus, het reflecteren op eigen ervaringen in de beroepspraktijk en het formuleren van leeropbrengsten, op basis van de uitgevoerde opdracht in de basisschool. Deelname aan de bijeenkomsten is verplicht, evenals het maken van de opdracht die fungeert als toets en wordt beoordeeld door een docent. In Figuur 7.1 is het onderwijsarrangement schematisch weergegeven.

\section{Bijeenkomst 1}

Training communicatieve vaardigheden met acteur, docent en peers

\section{Werken aan opdracht in basisschool}

Gesprek met ouders in authentieke context: 1 . voorbereiden, 2 . uitvoeren, videoopname maken, 3. analyseren en 4. reflecteren op persoonlijke ontwikkeling m.b.v. feedback mentor

Bijeenkomst 2

Analyse videocasus; Uitwisseling opdracht; Reflectie op communicatieve vaardigheden

S

Inleveren opdracht

Beoordeling door docent

Figuur 7.1: Opzet van onderwijsarrangement 4

De gehele interventie is erop gericht het toepassen van een conceptuele structuur hand in hand te laten gaan met het ontwikkelen van effectieve communicatieve vaardigheden, zodat een betekenisvolle relatie wordt gelegd tussen concepten en 
professioneel handelen. In dit vierde onderwijsarrangement worden beide elementen in samenhang geoefend in diverse situaties.

In de eerste bijeenkomst worden communicatieve vaardigheden geoefend met een acteur; deze semi-authentieke situatie ligt dichtbij de werkelijke situatie waarmee studenten in hun afstudeerstage worden geconfronteerd en waarin zij de opdracht uitvoeren. In deze trainingssessie worden met behulp van de eerder geleerde concepten door studenten ingebrachte communicatieve situaties geanalyseerd en wordt feedback gegeven op de getoonde communicatieve vaardigheden. De uit te voeren opdracht bestaat uit het voeren van een gesprek met ouders in de basisschool en het maken van een schriftelijke verantwoording van het professioneel handelen. De studenten maken individueel vooraf een schriftelijke voorbereiding en achteraf een schriftelijke analyse van het verloop van het gesprek. Met behulp van aandachtspunten worden de studenten in hun voorbereiding en analyse gericht op het communicatieve doel van het gesprek, de relatie met de ouders, hun eigen gespreksvaardigheden en contextfactoren die het gespreksverloop beïnvloeden. De opdracht bevat ook een reflectie op de communicatieve vaardigheden in het gevoerde gesprek en de ontwikkeling van deze vaardigheden tot dan toe. Hierbij wordt feedback van de mentor (basisschoolleraar) die het gesprek heeft bijgewoond, betrokken. Het gesprek zelf wordt met video opgenomen.

De tweede bijeenkomst betreft de analyse van een videocasus, het reflecteren op eigen ervaringen in de beroepspraktijk en het formuleren van leeropbrengsten, op basis van de uitgevoerde opdracht in de basisschool. Steeds wordt de conceptuele structuur gehanteerd om de eigen ervaringen in de beroepspraktijk te beschrijven. Met deze werkwijze wordt beoogd de conceptuele structuur op een betekenisvolle wijze te verbinden aan het eigen professioneel handelen en professioneel taalgebruik van aanstaande leraren te bevorderen.

De studenten leveren een eindproduct in waarin zij in de voorbereiding en analyse een verantwoording geven van hun professioneel gedrag met behulp van de conceptuele structuur. De analyse wordt ondersteund door delen van de videoopname die dienen als bewijsvoering voor een sterk en zwak stuk in het gevoerde gesprek. Het eindproduct bestaat uit drie onderdelen:

- verantwoording (voorbereiding en analyse van gesprek met ouders)

- selectie van videobeelden van gesprek met ouders

- reflectie op ontwikkeling van communicatieve vaardigheden.

De gehele opdracht voor studenten is opgenomen in Bijlage F.

\subsection{Onderzoeksmethode studie 1}

\section{Onderzoeksvragen}

In deze studie wordt onderzocht hoe de cognitieve flexibiliteit van studenten zich manifesteert in de schriftelijk verantwoording van hun professioneel handelen in een authentieke situatie. De authentieke situatie biedt de mogelijkheid om situatiespecifieke informatie in de verantwoording te integreren en concepten 
daarmee een situatiespecifieke inkleuring te geven. Daarom wordt de volgende onderzoeksvraag gesteld: Hoe verbinden studenten concepten en situatiespecifieke informatie in de schriftelijke verantwoording van hun handelen in een authentieke situatie?

Het betrekken van verschillende perspectieven op de communicatieve situatie is het derde element van cognitieve flexibiliteit. Daarom wordt tevens de vraag gesteld in hoeverre studenten verschillende perspectieven op de communicatieve situatie betrekken in hun verantwoording: In hoeverre betrekken studenten de perspectieven van ouder en school bij de schriftelijke verantwoording van hun handelen in een authentieke situatie?

Ten slotte wordt nagegaan in hoeverre studenten het niveau van cognitieve flexibiliteit dat voor afstuderende studenten wordt nagestreefd in dit laatste onderwijswijsarrangement bereiken: In hoeverre wordt het beoogde niveau van cognitieve flexibiliteit bereikt?

\section{Onderzoeksopzet}

In deze studie wordt een kwalitatieve onderzoeksbenadering gehanteerd. De studie is opgezet als een exploratieve, meervoudige gevalsstudie (Yin, 2009) met als doel het in kaart brengen van de wijze waarop cognitieve flexibiliteit zich als leerresultaat manifesteert in de schriftelijke verantwoording van professioneel handelen in een authentieke situatie. Om hiervan een gedifferentieerd beeld te verkrijgen zijn drie goede en zes voldoende gevallen geanalyseerd en vervolgens geduid in het licht van de beoogde cognitieve flexibiliteit. Vervolgens zijn de goede en voldoende gevallen onderling vergeleken en zijn overeenkomsten en verschillen gezocht. Hiermee wordt in kaart gebracht welke uitkomsten typerend zijn voor goede en voor voldoende gevallen. Ten slotte is een vergelijking getrokken tussen de goede en voldoende gevallen om te komen tot een beschrijving van het spectrum waarbinnen de bereikte cognitieve flexibiliteit in dit laatste onderwijsarrangement zich beweegt.

\section{Participanten}

Het onderwijsarrangement is uitgevoerd door alle voltijd vierdejaarsstudenten (169) van een lerarenopleiding. De studenten hebben de onderwijsarrangementen 1, 2 en 3 in voorgaande jaren doorlopen. Het onderwijsarrangement is uitgevoerd door drie docenten Nederlands. Zij hebben vooraf een gezamenlijke training gekregen over de opzet en bedoeling van het arrangement.

\section{Dataverzameling en procedure}

Het eindproduct van de student bestaat uit (a) een schriftelijke verantwoording van het handelen, (b) een selectie van videobeelden van het gevoerde gesprek met ouders en (c) een reflectie. Voor deze studie wordt gebruik gemaakt van (een deel van) de schriftelijke verantwoording. Deze bevat twee onderdelen: de voorbereiding en de analyse van een gesprek met ouders. De gesprekken met ouders die de studenten voeren, zijn vergelijkbaar van aard; vaak betreft het informatieve gesprekken over de voortgang van leerlingen (de zogenaamde 10-minutengesprekken). 
Het eindproduct wordt individueel en digitaal ingeleverd bij de docent en dient als individuele toets. Verzameld zijn alle eindproducten die in het lopende studiejaar zijn ingeleverd. In deze periode zijn 112 eindproducten verzameld. De overige producten zijn om diverse redenen later ingeleverd (vanwege studievertraging, ziekte, ict-problemen etc.).

\section{Selectie van gevallen}

Voor de selectie is gebruik gemaakt van de docentbeoordelingen, die tot stand zijn gekomen op grond van de beoordelingscriteria en scoringsvoorschriften. De beoordelingscriteria van de docent zijn gericht op het gebruik van concepten en situatiespecifieke informatie, het aspect perspectieven innemen is impliciet in de criteria opgenomen. De beoordeling kent vier niveaus, te weten goed, ruim voldoende, voldoende en onvoldoende. In Tabel 7.1 is weergegeven hoe de beoordelingen zijn verdeeld over deze vier niveaus. Studenten hebben de gelegenheid gehad voor een herkansing, wat het lage aantal onvoldoendes verklaart. Nagegaan is of de beoordeling door de verschillende docenten sterk uiteenliep, maar dat bleek niet het geval.

Voor deze studie is uit de dataset een gestratificeerde steekproef genomen uit de strata goed en voldoende. Op aselecte wijze zijn drie goede en zes voldoende gevallen geselecteerd. De als 'goed' geselecteerde gevallen worden in deze studie beschouwd als goed en de als 'voldoende' geselecteerde gevallen als voldoende. Met deze selectie van drie goede en zes voldoende gevallen wordt enerzijds in kaart gebracht wat het optimale resultaat van de interventie is en anderzijds wat een gangbaar resultaat is; op deze manier wordt recht gedaan aan de dataset waarin een kleine groep verantwoordingen is beoordeeld met goed (7\%) en een grote groep (73\%) met voldoende.

Tabel 7.1 Docentbeoordeling van verantwoording

\begin{tabular}{l|l|l|l|l} 
& Goed & Ruim voldoende & Voldoende & Onvoldoende \\
\hline Verantwoording (112) & $7 \%(8)$ & $15 \%(17)$ & $73 \%(82)$ & $4 \%(5)$
\end{tabular}

\section{Instrument}

Voor het analyseren van de wijze waarop studenten concepten en situatiespecifieke informatie met elkaar verbinden om hun handelen in een authentieke situatie te verantwoorden, is een instrument ontwikkeld met drie niveaus. In het vorige hoofdstuk is in navolging van Oonk (2009) een instrument gebruikt voor de analyse van conceptgebruik. In dit hoofdstuk is het analyse-instrument, in overeenstemming met de opbouw van het curriculum, gericht op meer facetten van cognitieve flexibiliteit, namelijk op het gebruik van concepten en van situatiespecifieke informatie.

1. Het eerste niveau betreft het beschrijven van situatiespecifieke informatie of concepten. Hieronder wordt verstaan dat studenten informatie die deze ene communicatieve situatie beïnvloedt, beschrijven of dat zij abstracte concepten concretiseren.

2. Het tweede niveau betreft het redeneren met situatiespecifieke informatie of met concepten. Hieronder wordt verstaan dat situatiespecifieke informatie of 
concepten worden betrokken in een redenering over het handelen. Met deze redenering wordt het handelen onderbouwd en verantwoord.

3. Het derde niveau betreft het samenhangend redeneren met situatiespecifieke informatie en concepten. Op dit niveau wordt het handelen onderbouwd met een redenering waarin situatiespecifieke informatie en concepten betekenisvol aan elkaar worden gekoppeld, zodat de concepten een door de situatie bepaalde inkleuring krijgen.

In Tabel 7.2 is het analyse-instrument weergegeven en wordt ieder niveau met voorbeelden, geïnspireerd op teksten van studenten, geïllustreerd.

Tabel 7.2 Analyse-instrument met voorbeelden

\begin{tabular}{|c|c|c|}
\hline $\begin{array}{l}\mathrm{Niv} \\
1\end{array}$ & $\begin{array}{l}\text { Beschrijven van situatiespecifieke } \\
\text { informatie } \\
\text { 'Ouders vinden prestaties heel } \\
\text { belangrijk en zijn onlangs zelfs verhuisd } \\
\text { om dichter bij de school te wonen; } \\
\text { komen meestal samen.' }\end{array}$ & $\begin{array}{l}\text { Beschrijven van concepten } \\
\text { 'Mijn expressieve boodschap is } \\
\text { belangstellend en professioneel. Ik } \\
\text { wil graag belangstellend en } \\
\text { professioneel overkomen.' }\end{array}$ \\
\hline $\begin{array}{l}\text { Niv } \\
2\end{array}$ & $\begin{array}{l}\text { Redeneren met situatiespecifieke } \\
\text { informatie } \\
\text { 'Ouders vinden prestaties heel } \\
\text { belangrijk en zijn onlangs zelfs verhuisd } \\
\text { om dichter bij de school te wonen; } \\
\text { komen meestal samen. } \\
\text { Daarom zal ik vragen hoe de verhuizing } \\
\text { hen tot nu toe bevalt. Omdat ik weet dat } \\
\text { de prestaties van hun dochter erg } \\
\text { belangrijk voor hen zijn, zal ik hen } \\
\text { inzage geven in de toetsresultaten. Dan } \\
\text { kunnen ze zich een beeld vormen. Maar } \\
\text { ik zal ook vertellen dat Myrie een heel } \\
\text { sociaal, sympathiek kind is en dat ik die } \\
\text { ontwikkeling ook erg belangrijk vind.' }\end{array}$ & $\begin{array}{l}\text { Redeneren met concepten } \\
\text { 'Mijn expressieve boodschap is } \\
\text { belangstellend en professioneel. Ik } \\
\text { wil graag belangstellend en } \\
\text { professioneel overkomen. } \\
\text { Daarom zal ik vragen hoe het met } \\
\text { hun gaat. Ook zal ik hen inzage } \\
\text { geven in de toetsresultaten, zodat ze } \\
\text { zich een beeld kunnen vormen van } \\
\text { de prestaties van hun dochter. En ik } \\
\text { zal vertellen dat Myrie een heel } \\
\text { sociaal, sympathiek kind is en dat ik } \\
\text { die ontwikkeling ook erg belangrijk } \\
\text { vind.' }\end{array}$ \\
\hline $\begin{array}{l}\text { Niv } \\
3\end{array}$ & \multicolumn{2}{|c|}{$\begin{array}{l}\text { Samenhangend redeneren met situatiespecifieke informatie en concepten } \\
\text { ‘Ouders vinden prestaties heel belangrijk en zijn onlangs zelfs verhuisd om } \\
\text { dichter bij de school te wonen; komen meestal samen. } \\
\text { Mijn expressieve boodschap is belangstellend en professioneel. Ik wil graag } \\
\text { belangstellend en professioneel overkomen. } \\
\text { Daarom zal ik vragen hoe de verhuizing hen totnutoe bevalt. Omdat ik weet } \\
\text { dat de prestaties van hun dochter erg belangrijk voor hen zijn, zal ik hen inzage } \\
\text { geven in de toetsresultaten. Dan kunnen ze zich een beeld vormen. Maar ik zal } \\
\text { ook vertellen dat Myrie een heel sociaal, sympathiek kind is en dat ik die } \\
\text { ontwikkeling ook erg belangrijk vind.' }\end{array}$} \\
\hline
\end{tabular}




\section{Dataverwerking}

De verantwoording van het handelen, bestaand uit een voorbereiding en een analyse van het gesprek met ouders, is opgedeeld in betekenisvolle eenheden. Deze eenheden zijn gebaseerd op de opdrachtformulering en vormen een inhoudelijke eenheid. De segmentering wordt vaak ondersteund door de manier waarop studenten de tekst vormgeven: met koppen, tussenkoppen en witregels wordt duidelijk gemaakt dat een bepaald tekstgedeelte een inhoudelijke eenheid vormt. De verantwoording bevat vier betekenisvolle eenheden: voorbereiding 1, voorbereiding 2 , analyse 1 en analyse 2 .

\section{Data-analyse}

Om onderzoeksvraag 1 te beantwoorden zijn voor ieder geval de betekenisvolle eenheden geanalyseerd met behulp van de categorieën van het analyse-instrument. De opdracht stuurt de student naar een bepaald niveau in het gebruik van concepten en situatiespecifieke informatie. In Tabel 7.3 is aangegeven welke inhoud in de betekenisvolle eenheden van de student wordt gevraagd.

Tabel 7.3 Inhoud van analyse-eenheden in verantwoording

\begin{tabular}{lll}
\hline $\begin{array}{l}\text { Analyse-eenheid } \\
\text { Voorbereiding 1 }\end{array}$ & $\begin{array}{l}\text { Essentie van opdracht } \\
\text { Beschrijf consistent de referentiële } \\
\text { boodschap, het communicatieve } \\
\text { doel en de gespreksopbouw. }\end{array}$ & $\begin{array}{l}\text { Gevraagd niveau } \\
\text { Niveau 1: Beschrijven van } \\
\text { concepten }\end{array}$ \\
Voorbereiding 2 & $\begin{array}{l}\text { Beschrijf en motiveer je expressieve } \\
\text { en relationele boodschap. Betrek } \\
\text { alle relevante situatiespecifieke } \\
\text { informatie in je voorbereiding. }\end{array}$ & $\begin{array}{l}\text { Niveau 3: Samenhangend } \\
\text { redeneren met } \\
\text { situatiespecifieke informatie } \\
\text { en concepten }\end{array}$ \\
Analyse 1 & $\begin{array}{l}\text { Beschrijf een gespreksfragment } \\
\text { waarin je tevreden bent over je } \\
\text { eigen handelen en motiveer je } \\
\text { oordeel. Gebruik hierbij concepten. }\end{array}$ & $\begin{array}{l}\text { Niveau 2: Redeneren met } \\
\text { concepten }\end{array}$ \\
\hline Analyse 2 & $\begin{array}{l}\text { Beschrijf een gespreksfragment } \\
\text { waarin je ontevreden bent over je } \\
\text { eigen handelen en motiveer je } \\
\text { oordeel. Gebruik hierbij concepten. }\end{array}$ & $\begin{array}{l}\text { Niveau 2: Redeneren met } \\
\text { concepten }\end{array}$ \\
\hline
\end{tabular}

Per eenheid is bepaald op welke niveaus concepten en situatiespecifieke informatie worden gehanteerd. Met uitgebreide citaten en deels met samenvattingen wordt in de analyse duidelijk gemaakt op grond waarvan de niveaubepaling tot stand is gekomen. Hierbij wordt het eerder gemaakte onderscheid tussen opdrachtgestuurde concepten en spontaan gehanteerde concepten gebruikt (zie ook hoofdstuk 6). In 
voorbereiding 1 en 2 worden vijf concepten in de opdracht bevraagd: communicatief doel, referentiële boodschap, gespreksopbouw, expressieve en relationele boodschap. Dit zijn de opdrachtgestuurde concepten. Het staat de student vrij om aan de voorbereiding andere concepten toe te voegen, dat zijn dan spontaan gehanteerde concepten. In analyse 1 en 2 selecteren studenten zelf relevante concepten voor de beschrijving en beoordeling van twee gespreksfragmenten. In deze analyse-eenheden is dus uitsluitend sprake van spontaan gehanteerde concepten.

Om onderzoeksvraag 2 naar de mate waarin studenten de verschillende perspectieven van ouder en school betrekken in hun verantwoording te beantwoorden, is de volgende werkwijze gehanteerd. Onder het perspectief van de ouder wordt verstaan dat de student er blijk van geeft zich te verplaatsen in de positie van zijn gesprekspartner en oog te hebben voor diens belang (analyse-aspect). Tevens laat de student zien dit inlevingsvermogen ook te concretiseren in het professioneel handelen, dat wil zeggen dat de student formuleert hoe hij in zijn handelen rekening houdt met zijn gesprekspartner (handelingsaspect). Onder perspectief van de schoolorganisatie wordt verstaan dat de student er blijk van geeft zich bewust te zijn van zijn positie als vertegenwoordiger van een organisatie. Hij is zich ervan bewust, als beginnend professional, mede de doelen van de organisatie te realiseren en 't organisatiebelang te behartigen. Dit kan zich uiten in verwijzingen naar formele bronnen van het schoolbeleid of naar de gang van zaken in de school (analyse-aspect).

Bij de analyse-eenheden is met behulp van citaten aangegeven welke perspectieven worden betrokken. Vervolgens is hieraan een kwalificatie gegeven: herhaaldelijk betrokken $(++)$, betrokken $(+)$, niet betrokken (-).

Om onderzoeksvraag 3 te beantwoorden, is nagegaan hoe de verschillende elementen van cognitieve flexibiliteit door studenten worden gecombineerd. Het beoogde niveau van cognitieve flexibiliteit wordt bereikt wanneer de drie elementen die worden onderzocht, namelijk het gebruik van concepten, het gebruik van situatiespecifieke informatie én het innemen van perspectieven, in combinatie op een bepaald niveau worden uitgevoerd:

- Redeneren met concepten en situatiespecifieke informatie (niveau 2 en 3); en

- Blijk geven van perspectiefwisseling (perspectief gesprekspartner en/of schoolorganisatie).

Om recht te doen aan de kwalitatieve onderzoeksaanpak is op basis van de analyses een duiding van ieder geval geschreven. In de duiding worden het niveau waarop concepten en situatiespecifieke informatie worden gehanteerd én de mate waarin de perspectieven worden ingenomen beschreven, geïllustreerd met behulp van citaten en parafrases en gekwalificeerd in het licht van de beoogde cognitieve flexibiliteit. In de duiding wordt ook de kwaliteit van het conceptgebruik betrokken. Aangegeven wordt in hoeverre concepten juist of onjuist zijn geïnterpreteerd door studenten, of concepten uitgewerkt worden met subconcepten en in hoeverre er sprake is van het gebruik van opdrachtgestuurde of spontaan gehanteerde concepten. 
Iedere duiding is opgebouwd met de volgende elementen: (a) voorbereiding, (b) analyse, (c) perspectieven en (d) conclusie. Deze duidingen zijn opgenomen in paragraaf 7.3.

\subsection{Resultaten}

\subsubsection{Duiding van drie goede gevallen}

\section{Duiding van geval 1: Robijn Voorbereiding}

In voorbereiding 1 worden de opdrachtgestuurde concepten (referentiële boodschap, communicatief doel, opbouw gesprek) door Robijn juist en consistent beschreven met behulp van een adequate selectie van subconcepten (niveau 1). Met name de gespreksopbouw kent veel subconcepten (inleiding, opening, doelaanduiding, vooruitblik, randvoorwaarden, kern, afsluiting, metacommunicatie, social talk) en is ook inhoudelijk uitgebreid. Een voorbeeld hiervan:

'Afsluiting:

- Ik vat het gesprek kort samen en vertel tot slot dat D. een fijne leerling is om de klas te hebben.

- Meta communicatie: Ik geef aan hoe ik het gesprek ervaren heb.

- Vervolgens maak ik eventuele vervolg afspraken. Ik vertel dat ze altijd bij me mogen komen en dat ik hen ook op de hoogte houd als er iets bijzonders is.

- Socialtalk (koetjes en kalfjes).'

Bij de gespreksopbouw neemt Robijn ook spontaan concepten op: relevante gespreksvaardigheden worden genoemd (o.a. verifiëren van begrip, samenvatten, structureren, afstemmen van doelen, afspraken maken). Twee voorbeelden hiervan:

'We bespreken wat we van elkaar verwachten en stemmen onze doelen hierop af.'

'Ik bespreek structuur van het gesprek en controleer of ze het hiermee eens zijn.'

Robijn laat hiermee zien dat ze de conceptuele structuur beheerst en weet toe te passen.

Verder voert Robijn een redenering aan voor haar handelen, waarbij ze concepten en situatiespecifieke informatie verbindt (niveau 3). Ze verantwoordt de gespreksopbouw door toe te lichten dat in dit specifieke geval afgeweken wordt van de gebruikelijke aanpak, met als argument dat het gesprek plaatsvindt zonder dat de ouders het rapport hebben kunnen lezen. Deze specifieke omstandigheid leidt ertoe dat ze haar gespreksopbouw aanpast.

'Vervolgens stel ik voor dat ouders eerst rustig het rapport gaan bekijken. Wanneer er dingen opvallen kunnen ze dat meteen vragen. Daarna nemen we het rapport samen door en vertel ik per onderdeel de belangrijkste punten.'

Robijn toont hiermee kennis van concepten, kennis van de gebruikelijke aanpak en gevoel voor de specifieke situatie waarin ander gedrag gepast is.

Andere situatiespecifieke informatie (over de school en ouders en over de waarden/uitgangspunten van de school) wordt door Robijn beschreven maar niet 
betrokken in een redenering (niveau 1). Deze informatie typeert de school en de ouders in algemene zin en is relevant voor een beeld van de context waarin de gesprekssituatie zich afspeelt (zie Perspectieven).

In voorbereiding 2 motiveert Robijn haar handelen met behulp van situatiespecifieke informatie en concepten (niveau 3). Ze beschrijft haar positieve persoonlijke band met de ouders:

'Ik heb met de moeder van D. goed contact. Op de donderdag en de vrijdag maak ik altijd een praatje met haar. Ze is een gezellige vrouw, kletst gemakkelijk en graag en houdt wel van een grapje. De moeder van D. is erg betrokken bij school. Ze is klassenouder en organiseert veel. Ze hoorde van mijn portfolio-opdracht en ze stelde zelf voor, dat ik wel van haar het 10 min. gesprek mocht opnemen. Met de vader van D. heb ik minder contact. Die heb ik nog maar één keer eerder gezien, tijdens de eerste 10 min. gesprekken. Ik vond het meteen een aardige man.'

Vervolgens betrekt ze deze band bij de concretisering van het concept relationele boodschap.

'Mijn relationele boodschap is dat ik erg tevreden over D. ben en dat ik beide ouders dus graag mag. Ook laat ik de ontvangers (de ouders van D.) vrij in het gesprek. Ik wil zorgen voor een open en ontspannen sfeer.'

Robijn toont een passende invulling van het concept in deze specifieke situatie en laat zien dat ze haar handelen aanpast aan de gesprekspartner.

Daarnaast beredeneert Robijn haar handelen met situatiespecifieke informatie over het communicatiebeleid van de school (niveau 2). Zij laat middels een passend citaat uit het schoolplan zien dat ze het communicatiebeleid kent en hoe ze daarnaar handelt. Concreet wordt toegelicht hoe zij 'goede contacten met de ouders onderhoudt'. Dit getuigt van organisatiebewustzijn. Robijn laat zien dat zij als een professional in staat is te handelen in overeenstemming met het belang van de organisatie (zie Perspectieven).

Robijn hanteert ten slotte een concept in beschrijvende zin ('Mijn expressieve boodschap naar de ouders van $D$. is dat ik een betrokken, open, eerlijke, vrolijke en positieve leerkracht ben') en beschrijft situatiespecifieke informatie over de gespreksopstelling (niveau 1). Hieraan worden geen conclusies voor het handelen verbonden.

\section{Analyse}

In analyse 1 betrekt Robijn relevante concepten (opening, structureren, begrip controleren, randvoorwaarden, non-verbale communicatie) in de beschrijving van het communicatief handelen en beredeneert zij expliciet wat goed is aan het communicatief handelen. Daarnaast betrekt Robijn situatiespecifieke informatie (over de relatie met de ouders en over voorafgaand gesprek met de ouders) in diverse redeneringen waarmee ze haar communicatief gedrag verantwoordt. De analyse bestaat uit redeneringen op niveau 2 en 3 .

Een voorbeeld waarin Robijn met concepten en situatiespecifieke informatie haar handelen beredeneert (niveau 3):

'Hierna vertel ik kort hoe ik $D$. in de klas zie, ik benoem haar positieve kenmerken. Je ziet dat ouders hiervan stralen. Vervolgens structureer ik het gesprek door te vertellen hoe we 
het gesprek indelen. Nadat ik dit heb verteld, controleer ik of ouders dit ook goed vinden. Ik vind het belangrijk om het gesprek voor te structureren zodat beide partijen weten wat er wordt verwacht. Ik ben vergeten te vermelden wat de randvoorwaarden zijn, maar dit heb $i k$ eigenlijk vooraf al met de ouders van $D$. besproken en ik vond het eigenlijk onzin om dit dan nog een keer te doen.'

Een voorbeeld waarin situatiespecifieke informatie wordt betrokken (niveau 2):

'Ik vind het goed dat ik eerst vraag of ouders belangrijke vragen hebben of ergens tegenaan lopen zodat we hier eventueel genoeg aandacht aan kunnen schenken. Ik had al wel het vermoeden dat dit niet het geval was omdat ik redelijk veel contact met de moeder heb en ik dit dan al wel geweten had.'

In analyse 2 betrekt Robijn opnieuw concepten en situatiespecifieke info in redeneringen over haar handelen (niveau 3). Ze analyseert het gespreksverloop met concepten (kern, afsluiting, samenvatten, vragen formuleren, social talk) en veel situatiespecifieke info. Zo beredeneert ze waarom er weinig interactie in de kern van het gesprek was en betrekt ze hierin drie situatiespecifieke factoren:

- Gedegen voorbereiding maakt dat ze zelf veel heeft te vertellen;

- Goed-nieuwsgesprek blijkt lastiger dan verwacht (geen 'issues');

- Ouder blijkt minder spraakzaam dan normaliter.

De laatste twee aspecten worden als volgt verwoord:

'Maar dit was dus eigenlijk een heel gemakkelijk gesprek, maar hierdoor ook wel weer moeilijk, omdat je niet heel veel te bespreken hebt. Toen de moeder van D. aanbood om haar gesprek te filmen was ik ook erg blij, want ik weet dat ze normaal erg veel kletst en heel direct is. Ik dacht dat is goed voor mijn film, maar tijdens het gesprek was ze dus heel rustig. Zo ken ik haar eigenlijk niet.'

Robijn formuleert tenslotte ook een oplossing voor het gebrek aan interactie: van tevoren vragen formuleren om aan de ouders te stellen.

In een ander deel van de analyse beredeneert Robijn waarom ze niet tevreden is over de afsluiting van het gesprek. Ze betrekt daarin enkele concepten en twee situatiespecifieke factoren: haar duopartner mengt zich in 't gesprek en de ouder neemt't initiatief tot de afsluiting (niveau 3).

'Waar ik niet tevreden over ben, is de afsluiting. Het gesprek had ik dus eigenlijk al min of meer afgesloten; had het gesprek samengevat, aangegeven dat ze altijd bij me terecht kunnen en ik hen ook op de hoogte houd als er iets is. Hierna kwamen de ouders dus met vragen (duopartner mengt zich in gesprek) en werd het meer een echt gesprek tussen ons vieren. Op een gegeven moment merkte je dat er een stilte viel en we elkaar aankeken. Vader gaf aan geen vragen meer te hebben en moeder zei: 'Klaar'. Ik vond het raar om toen nog een keer het gesprek samen te vatten. Ik heb hen dus bedankt voor het gesprek en vervolgens heb ik de camera uitgezet. Nadat de camera uit was, hebben we nog even gepraat (social talk). Al met al duurde het gesprek dus iets langer.'

Met de uitgebreide analyse toont Robijn aan dat ze in staat is haar eigen handelen adequaat te analyseren, te zien welke factoren invloed hebben op de gesprekssituatie en betekenis te geven aan de concepten. Ze verwoordt dit in redeneringen op niveau 2 en 3. 


\section{Perspectieven}

1. Perspectief ouder. Het perspectief van de ouders als gesprekspartner is verweven in de gehele voorbereiding. Robijn leeft zich in het perspectief van de ouders in, houdt rekening met hun (mogelijke) gevoelens en benadert de ouders als gelijkwaardige gesprekspartners. Kenmerkend is dat Robijn concreet formuleert hoe ze in haar handelen rekening houdt met de gevoelens en belangen van de ouders. Bovendien hanteert in de formulering hiervan geregeld concepten op het gebied van gespreksvaardigheden. Enkele voorbeelden van aandacht voor het ouderperspectief:

'Ik vertel wat ik vooral zie en hoor in de klas en ik controleer of ouders dit ook zien of horen door hiernaar te vragen.'

'Ik vraag of de ouders vragen hebben, voordat ik de tijd volpraat, terwijl zij nog belangrijke vragen hebben.'

Ook in de analyse heeft Robijn oog voor het perspectief van de ouders en integreert ze concepten bij het innemen van dat perspectief. Haar positieve oordeel is gebaseerd op het (positieve) effect van de gespreksvaardigheden op de ouders. Voorbeelden die dit illustreren:

'Hierna vertel ik kort hoe ik D. in de klas zie, ik benoem haar positieve kenmerken. Je ziet dat ouders hiervan stralen.'

'Ik controleerde tijdens het gesprek of ouders de informatie hebben begrepen en lette vooral op hun non-verbale communicatie of ik controleerde dit d.m.v. vragen. Ouders reageerden vooral non-verbaal op wat ik zei en dit is voor mij een goed teken. Ze waren betrokken bij het gesprek en tevreden over hoe het gaat.'

Robijns aandacht voor het ouderperspectief blijkt ook uit het achteraf navraag doen bij de ouders:

'Ik heb ouders na de tijd gevraagd wat ze vonden van het gesprek en gelukkig gaven ze aan dat ze tevreden waren over het gesprek. Zij gaven ook aan dat ze wel een beetje zenuwachtig waren voor de camera.'

2. Perspectief school. Robijn houdt in haar handelen rekening met het perspectief van de school door zich expliciet te verhouden tot het communicatiebeleid en te laten zien hoe zij in haar handelen rekening houdt met het beleid. Middels een citaat uit het schoolplan laat ze zien dat ze het communicatiebeleid kent en hoe ze daarnaar handelt (zie Voorbereiding). Dit getuigt van organisatiebewustzijn. Robijn laat zien dat zij als een professional in staat is te handelen in overeenstemming met het belang van de organisatie.

\section{Conclusie}

Robijn laat zien dat ze de conceptuele structuur beheerst. Zij hanteert de opdrachtgestuurde concepten juist en toont diepgaand begrip van concepten door veel subconcepten op te nemen in haar verantwoording (niveau 1). Bovendien integreert ze spontaan diverse concepten in de voorbereiding en analyse wat wijst op een goede beheersing van de concepten.

Zowel in de voorbereiding als in de analyse beredeneert Robijn haar handelen met concepten en relevante situatiespecifieke informatie (niveau 2 en 3). Situatiespecifieke informatie speelt een grote rol in Robijns voorbereiding en analyse. Inhoudelijk zijn voorbereiding en analyse sterk: verschillende aspecten van de situatie worden 
uitgediept met oog voor details. Robijn laat ook zien haar handelen aan de specifieke situatie aan te kunnen passen. In de analyse toont Robijn aan dat ze in staat is haar eigen handelen adequaat te analyseren, te zien welke factoren invloed hebben op de situatie en betekenis te geven aan de concepten. Een enkele keer wordt situatiespecifieke informatie alleen genoemd en niet betrokken in redenering, zoals een algemene typering van de schoolpopulatie ('witte school, hoogopgeleide ouders') of van de waarden van de school.

Perspectieven van de schoolorganisatie en de ouders worden beide betrokken in de verantwoording. Het ouderperspectief wordt consequent beschreven en geconcretiseerd in het handelen. Ook het communicatiebeleid van de school wordt benoemd met een formele bron en bewust nageleefd.

In Robijns geval wordt cognitieve flexibiliteit overtuigend bereikt op het beoogde niveau. Het handelen wordt steeds verantwoord in redeneringen waarin concepten en/of situatiespecifieke informatie betekenisvol zijn betrokken, vaak op niveau 3 en soms op 2.

De gehele verantwoording is doordesemd van het perspectief van de ouder: uit alle handelingen van Robijn blijkt dat zij zich bewust is van het effect van haar communicatief handelen op de ouders en dat zij haar handelen consequent afstemt op haar gesprekspartner. Ook het perspectief van de school wordt betrokken, wat ervan getuigt dat Robijn zich bewust is van haar rol als professional in een organisatie en daarnaar handelt.

\section{Duiding van geval 2: Chery Voorbereiding}

De opdrachtgestuurde concepten worden door Chery in voorbereiding 1 juist beschreven en consistent gehanteerd. Inhoudelijk worden de concepten uitgebreid uitgewerkt (niveau 1). Eén opdrachtgestuurd concept wordt door Chery betrokken in een redenering over haar handelen (niveau 2). $\mathrm{Zij}$ beredeneert hoe ze haar motiverende communicatieve doel vormgeeft:

'Het communicatieve doel van mij is informatief en enigszins motiverend. Ik wil de ouder(s) namelijk informatie verschaffen over hoe hun kind functioneert in en buiten de klas. Daarbij wil ik ook ingaan op de fysiotherapietherapie die de leerling krijgt en hierbij de ouder(s) motiveren om de leerling bij de fysiotherapie met de nieuwe lijn-liniatuur te laten oefenen. Om de ouder(s) hierbij te overtuigen laat ik werk van de leerling zien.'

Chery laat zien concepten juist te kunnen hanteren op niveau 1 en 2. Daarnaast beschrijft zij situatiespecifieke informatie die relevant is voor een goed begrip van de gesprekssituatie (niveau 1). De opstelling van haar mentor maakt het Chery lastig om zelfstandig een gesprek te voeren.

'Vooraf was er wel een klein probleem. Mijn mentrix stond er namelijk op dat wij gezamenlijk het gesprek zouden voeren waarbij ik de leiding nam. Ik heb dit moeten accepteren om de opdracht uit te kunnen voeren.' 
In voorbereiding 2 betrekt Chery situatiespecifieke informatie en twee concepten in redeneringen over haar handelen (niveau 3). Zo beredeneert ze de invulling van het concept expressieve boodschap op basis van haar familierelatie met de ouders en andere kenmerken van de ouders. Zij wil een professionele band met de ouders creëren, juist omdat ze hen uit haar privéleven kent - en met hen samenwerken, omdat de ouders samenwerking tussen school en thuis ook belangrijk vinden.

'Mijn relatie met hen is nauwer dan met andere ouders aangezien ik hen al langer ken. Zij zijn namelijk achterfamilie van mij, vandaar dat dit gesprek ook redelijk vertrouwd zal zijn voor beide partijen. Als expressieve boodschap wil ik laten zien en merken dat ik als leerkracht in overleg met de ouder(s) oplossingen wil bedenken. Ik wil rustig en professioneel overkomen waarbij ik weet waar ik over praat en de ouders ook antwoord kan bieden op hun vragen. Ik wil ook zelfverzekerd overkomen maar mij wel kwetsbaar op te durven stellen om zo een "professionele" band met de ouders te creëren (aangezien ik hen vanuit mijn privéleven ken).'

Chery beredeneert ook de invulling van het concept relationele boodschap op basis van situatiespecifieke informatie over de ouders. Zij beschrijft haar handelen en beredeneert welk effect deze relationele boodschap heeft op de ouders.

'De ouders van Mart staan open voor suggesties van de school en zijn ook daadwerkelijk geïnteresseerd in hun kind. Ze willen niet hun eigen zin doordrijven maar willen in overleg met de school/leerkracht naar de beste oplossing zoeken (...) Als relationele boodschap wil ik laten zien aan de ouders dat ik hen mening waardeer en hier ook iets mee doe. Ook wil ik de informatie die zij verschaffen meenemen in de klas en buiten de klas. Dit wil ik hen ook aangeven wanneer dit van toepassing is. Op die manier wil ik de ouders laten merken dat ik iets doe met de informatie die zij mij geven en dat ik hen serieus neem.' Chery toont met haar aanpak een juist begrip van de concepten expressieve en relationele boodschap, gevoel voor een passende invulling ervan in deze specifieke situatie en zij weet haar handelen aan te passen.

In voorbereiding $2 \mathrm{komt}$ Chery terug op eerder genoemde situatiespecifieke informatie over haar mentor. $\mathrm{Nu}$ verbindt ze daaraan ook gevolgen voor haar handelen (niveau 2). Ze beschrijft hoe het gedrag van haar mentor haar eigen gespreksvoering in de weg kan staan ('mentor neemt leiding snel over') en beredeneert hoe ze dat kan voorkomen tijdens het gesprek ('niet stilvallen, niet ondersneeuwen') en voorafgaand aan het gesprek ('mentor goed informeren over de bedoeling'). Chery weegt voor- en nadelen van haar handelen af, plaatst de afwegingen in verband met haar opvatting over communicatie en betrekt het perspectief van de ouders hierin:

'Als overige informatie is belangrijk dat mijn mentrix snel de leiding overneemt. Hier moet $i k$ voor oppassen. Wel vind ik het belangrijk haar ook naar haar mening te vragen zodat de ouders merken dat mijn mentrix en ik ons beiden inzetten voor een bepaald actiepunt en dat wij hier ook beiden achter staan. Wanneer mijn mentrix de leiding overneemt moet ik oppassen dat ik niet ondersneeuw, dat ik niet stilval omdat ik het gevoel heb dat zij het beter weet. Echter kan dat ook een gevaar zijn, namelijk dat er door elkaar gepraat zal worden. Ik heb van tevoren wel duidelijk aangegeven aan mijn mentrix dat het de bedoeling is dat ik het gesprek leid.' 
Chery laat impliciet blijken dat ze in een moeilijk parket zit. Ze is als stagiaire niet in de positie haar mentor te bekritiseren, maar ze heeft wel kritiek op haar gedrag. Chery moet haar rol in het oudergesprek bevechten: zij wil meer zelfstandigheid dan de mentor haar toestaat. Chery blijkt echter in staat om deze lastige situatie met enige distantie te beschrijven, haar communicatieve handelen aan de situatie aan te passen en steeds het belang van een effectieve communicatie met de ouders voorop te stellen.

Ten slotte beredeneert Chery de ruimtelijke opstelling van tafels en stoelen waarbij ze twee inhoudelijke argumenten geeft en situatiespecifieke informatie ('noodgebouw') betrekt (niveau 2). Hiermee laat Chery zien dat ze zich bewust is van het effect van de ruimtelijke opstelling op de communicatie.

\section{Analyse}

In de beschrijving en positieve beoordeling van het communicatieve gedrag (analyse 1) hanteert Chery veel subconcepten, behorend bij de basisconcepten gespreksvaardigheden en gespreksopbouw (non-verbale en verbale technieken, knikken, gebaren, ja zeggen, vragen stellen, doorvragen, samenvatten, reflecteren op gevoel, parafraseren, reageren op voorstellen, doorvragen, structureren; inleiding, social talk, kern, afsluiting). Deze concepten worden geïllustreerd met concrete voorbeelden uit het gesprek. Een voorbeeld:

'Je ziet in het gesprek dat ik veel gesprekstechnieken/ gespreksvaardigheden toepas als luisteraar. Ik pas zowel non-verbale als verbale technieken toe. Zo knik ik, ik luister echt naar de vader van Mart. Ik maak gebaren bij bijvoorbeeld 'hij wil heel veel vertellen'. Verder moedig ik de ouder aan door te knikken, door een aantal keer ja te zeggen. Ik stel vragen, vraag door maar vat ook samen. Daarbij reflecteer ik ook op het gevoel van Mart.'

Chery laat in haar uitgebreide analyse zien dat zij de concepten kan betrekken in redeneringen over haar eigen handelen (niveau 2). Argumenten worden gegeven voor de positieve waardering op basis van het geformuleerde persoonlijke aandachtspunt: Het is gelukt om in overleg met de ouder tot oplossingen te komen, want ze heeft enerzijds allerlei gespreksvaardigheden als luisteraar ingezet en heeft anderzijds actief als gesprekspartner geparticipeerd door gespreksvaardigheden als spreker in te zetten. Chery laat zien dat zij concepten kan concretiseren met behulp van voorbeelden uit het gespreksverloop, maar ook dat zij concepten op een abstracter, meer samenvattend niveau kan hanteren om het doel van haar gesprekstechnieken toe te lichten:

'Kortom ik heb de vader van Mart gestimuleerd te vertellen met mijn gesprekstechnieken

(bijv. ja zeggen, knikken, doorvragen, etc.) maar ik heb ook gereageerd op zijn standpunten, voorstellen (of Mart weer naar schrijftherapie moet) en ideeën, ik heb gereageerd op gedrag en heb het gesprek gestructureerd (gespreksverloop) door een inleiding (Social-talk: lachen om dat het gesprek mooi maar 10 minuten duurt) en met behulp van de vraag 'Hoe gaat het met Mart in de klas' is er een overgang naar de kern.'

Inhoudelijk is de analyse uitgebreid en worden diverse aspecten van het gespreksverloop geanalyseerd. Chery betrekt ook situatiespecifieke informatie en concepten in een redenering over haar handelen (niveau 3). Het gaat - net als in de voorbereiding - om het gedrag van haar mentor. Chery is teleurgesteld over de afsluiting van het gesprek. $\mathrm{Zij}$ analyseert met behulp van concepten (opbouw 
gesprek, structureren, vragen stellen, referentiële boodschap) de situatie (mentor neemt gesprek over) en beredeneert haar oplossing (hoe ze de leiding in het gesprek heeft weten te hernemen). Ze waardeert dit positief, omdat dit een tweede persoonlijk aandachtspunt van haar was.

'Als eind sluit helaas mijn mentrix af. Dit vond ik erg jammer. Ik heb de opbouw van het gesprek in de gaten gehouden en gestuurd door bepaalde vragen te stellen. Zo vroeg ik hoe het met Mart in de klas ging. Aan het eind had ik willen vragen of de vader van Mart nog vragen had. Het was jammer dat mijn mentrix afsloot op het moment dat ik dit had willen doen. Wanneer mijn mentrix de leiding overnam dan bleef ik me wel met het gesprek bemoeien en liet ook mijn standpunt horen. Op die manier kon ik de leiding weer overnemen. Wel liet $i k$ de vader van Mart en mijn mentrix vrij om te vertellen wat zij graag wilden. Ik hield ook leiding door de lijst met de referentiële boodschap bij mij te houden. Ik droeg punten aan waar ik het over wilde hebben en bracht zo structuur in het gesprek en nam hiermee ook de leiding.'

Hiermee toont Chery aan dat zij relevante situatiespecifieke informatie en concepten in een analyse kan verbinden, en dat zij haar handelen aan de situatie aanpast waardoor de situatie acceptabel blijft voor haarzelf, de mentor en de ouder.

De beschrijving van een gespreksfragment waarover ze niet tevreden was, is minder uitgebreid. Chery analyseert de situatie (mentor voert het woord en zijzelf is stil) en beredeneert waarom deze situatie niet goed is. Ze gebruikt daarbij een niet bestaand concept (intern communicatiebeleid), waarvan de bedoeling duidelijk is (niveau 3).

\section{Perspectieven}

1. Perspectief ouder. In de voorbereiding betrekt Chery consequent het perspectief van de ouder. Ze laat in haar redeneringen - waarbij ze concepten hanteert - blijken zich bewust te zijn van het perspectief van de ouder en van haar eigen rol als professional met oog voor het belang van het kind. Chery past haar handelen hierop aan. Voorbeelden zijn te vinden in diverse redeneringen:

Hoewel Chery wil voorkomen dat de mentor de leiding van het gesprek overneemt, wil ze de mentor wel het woord geven:

'Wel vind ik het belangrijk haar ook naar haar mening te vragen zodat de ouders merken dat mijn mentrix en ik ons beiden inzetten voor een bepaald actiepunt en dat wij hier ook beiden achter staan.'

In de redenering over haar relationele boodschap:

'Op die manier wil ik de ouders laten merken dat ik iets doe met de informatie die zij mij geven en dat ik hen serieus neem.'

In het persoonlijke aandachtspunt:

'Ik wil oefenen dat ik samen in overleg met de ouder(s) naar een oplossing zoek. Dit wil ik oefenen omdat ik denk dat dit belangrijk is voor de relatie tussen de ouder(s) en mij maar ook omdat dit ten goede komt aan de ontwikkeling van het kind. Op deze manier zitten de ouder(s) en ik namelijk beter op één lijn dan wanneer één van de partijen zijn/haar zin doordrijft.'

Ook in de analyse heeft Chery oog voor het perspectief en de reactie van de ouder in het gesprek, benoemt ze dit expliciet en illustreert ze dit met behulp van een voorbeeld. 
'Ook parafraseer $i k$. Je kunt zien dat de vader van Mart dit fijn vind. Zo legt de vader uit hoe Mart zich in de klas en buiten de klas voelt. Ik parafraseer door te zeggen dat Mart onzeker is. Uit de reactie van de ouder blijkt dat dit het woord is wat bij zijn omschrijving hoorde. Ik verplaats mij echt in het perspectief van de ouder en laat merken dat ik hem begrijp.'

2. Perspectief school. Het perspectief van de school wordt niet betrokken in de verantwoording.

\section{Conclusie}

Chery toont aan dat ze de conceptuele structuur beheerst. In de voorbereiding hanteert ze de opdrachtgestuurde concepten juist en samenhangend, in de analyse betrekt ze spontaan opvallend veel (sub)concepten waarmee een diepgaand begrip van de concepten wordt getoond.

De verantwoording bestaat hoofdzakelijk uit redeneringen met aandacht voor details (niveau 2 en 3). Chery verbindt herhaaldelijk relevante situatiespecifieke informatie met concepten in redeneringen over haar handelen (niveau 3). Ze laat daarmee zien dat ze situatiespecifieke factoren die van invloed zijn op de gesprekssituatie weet te selecteren en concepten betekenisvol weet te maken voor haar handelen. Bovendien past ze haar handelen aan de situatie aan en weet ze dit adequaat en consequent te beredeneren.

Chery heeft te maken met een lastige situatie (bevechten gespreksleidersrol). Zowel de voorbereiding als de analyse getuigt van een professionele houding tegenover dit probleem. Chery blijkt in staat om deze situatie met enige distantie en met behulp van concepten te beschrijven, haar communicatieve handelen aan de situatie aan te passen en het belang van een effectieve communicatie met de ouders voorop te stellen.

Het perspectief van de ouders wordt consequent betrokken in de voorbereiding en analyse doordat Chery zich voortdurend rekenschap geeft van het effect van haar handelen op de ouder. Aandacht voor het belang van de mentor blijkt ook. Het perspectief van de school ontbreekt.

In het geval van Chery wordt cognitieve flexibiliteit op het beoogde niveau overtuigend bereikt. Het handelen wordt steeds verantwoord in redeneringen op niveau 2 en 3 waarbij concepten en situatiespecifieke informatie betekenisvol met elkaar worden verbonden. De verantwoording is doordesemd van het perspectief van de ouders die respectvol en als gelijkwaardige gesprekspartners worden benaderd. Opvallend hierin is een professionele attitude in een lastige communicatieve situatie, waarmee blijk wordt gegeven van het besef dat de relatie tussen ouder en leerkracht in dienst staat van de ontwikkeling van het kind. Een beperking is het ontbrekend perspectief van de school. 


\section{Duiding van geval 3: Ella Voorbereiding}

In voorbereiding 1 beschrijft Ella de opdrachtgestuurde concepten juist en consistent met behulp van een adequate selectie van subconcepten. De voorbereiding is uitgebreid en wordt ondersteund met zes passende citaten uit een studieboek over communicatie. Naast de opdrachtgestuurde concepten neemt zij ook spontaan een concept op (samenvatten). Ella laat met deze werkwijze zien dat ze de conceptuele structuur juist kan hanteren op niveau 1 . Een voorbeeld van haar aanpak:

'In mijn gesprek met de vader van Linde zijn er twee doelen die centraal staan.

1. Informatief. Ik wil mijn verslag doen over de resultaten van Linde op school. Ik wil duidelijk maken en uitleggen dat het leesonderwijs van Linde niet verbeterd, maar blijft hangen op hetzelfde niveau.

2. Motiverend. Ik wil Dhr. T er toe zetten en motiveren om thuis ook bezig te gaan met lezen. Ik wil overtuigen dat het goed is om Linde te motiveren en op die manier het leesonderwijs te verhogen.

'Informatief. Er is sprake van een informatie doel als de zender kennis wil overdragen.'

'Motiverend: Een motiverende doelstelling gaat verder dan een persuasieve. De zender wil de ontvanger niet alleen overtuigen van een standpunt, maar hij wil ook bereiken dat deze bereid is (de intentie heeft) om iets te doen of te laten.' Bron: Steenhouder M. Jansen C. Maat K. van der Staak J. de Vet D. Witteveen M. Woudstra E. (2006).'

Daarnaast redeneert zij ook over haar handelen met het concept gespreksopbouw (niveau 2). In het volgende voorbeeld gebruikt ze subconcepten (inleiding, social talk, vooruitblik) en beredeneert zij de functie van social talk. Het citaat uit het studieboek functioneert, net als de overige citaten in de voorbereiding, als een extra onderbouwing voor het handelen, maar wordt niet expliciet in de redenering betrokken.

'Tijdens het tien-minuten-gesprek begin ik met een korte inleiding. Ik begroet de vader en geef hem een hand. Ik voer een social talk om hem op zijn gemak te laten voelen. Daarna maak ik duidelijk wat ik van het gesprek verwacht. Ik geef een korte vooruitblik over het verloop van het gesprek en als laatst bespreek ik de randvoorwaarden, zoals de tijdsduur, video-opname en vertrouwelijkheid.

'De inleiding is bepalend voor het verdere verloop en de sfeer van het gesprek.' Bron: Steenhouder M. Jansen C. Maat K. van der Staak J. de Vet D. Witteveen M. Woudstra E. (2006).'

Redeneren over het handelen vindt ook plaats met situatiespecifieke informatie (niveau 2). Ella beschrijft de positieve samenwerking en taakverdeling met haar mentor en beredeneert waarom dit handelen nuttig is voor de ouders:

'Basisschool 'de Meander' heeft twee keer in het jaar een tien-minuten-gesprek. De eerste gesprekken in november heeft mijn mentor geopend en ik vulde aan. De tweede gesprekken in maart voer ik en vult mijn mentor aan. Op die manier laten wij zien dat we allebei leerkracht zijn van de groep. Mijn mentor vindt het belangrijk dat ik ook de tien-minutengesprekken voer. Hiermee doe ik veel ervaring op.'

Ella laat hiermee zien dat ze situatiespecifieke informatie weet te selecteren en kan beredeneren welk effect deze heeft op de situatie. 
In voorbereiding 2 betrekt Ella concepten en situatiespecifieke informatie samenhangend in redeneringen over haar handelen (niveau 3). Eén voorbeeld daarvan betreft de relationele boodschap die, mede op grond van situatiespecifieke informatie, wordt beschreven en beredeneerd. Zo wordt er getutoyeerd, want 'De vader van Linde is voor mij geen vreemde, de aanspreekvorm verandert daardoor.' Verder wordt de vormgeving van de relationele boodschap met behulp van concepten (inleiden, afsluiten, social talk) in verscheidene redeneringen beschreven. Met een citaat uit Steehouder (2006) waarin wordt gesteld dat ontvangers gevoelig zijn voor de wijze waarop ze worden aangesproken, wordt het eigen communicatief handelen gemotiveerd. Ella hanteert daarom 'neutraal taalgebruik, niet te ingewikkeld, maar ook geen jip-en-janneketaal' en gaat de ouder 'niet commanderen, maar overtuigen met argumenten'. Hiermee toont Ella een juist begrip van het concept relationele boodschap en geeft ze een passende invulling van het concept in deze situatie.

Een tweede voorbeeld van samenhangend redeneren met situatiespecifieke informatie en een concept (non-verbale communicatie) betreft de ruimtelijke opstelling van de gesprekssituatie. Ella beschrijft welke opstelling (tegenover elkaar) en ruimte (klaslokaal) ze heeft gekozen en welke invloed dat heeft op het handelen. De positionering van ouder en leerkracht ten opzichte van elkaar leidt tot elkaar recht aankijken, zich prettig voelen en het waarnemen van non-verbale communicatie.

'Zelf zit ik achter mijn bureau en de ouder aan tafel. We zitten tegenover elkaar en kunnen elkaar recht aankijken. De afstand tussen de ouder en mij is ongeveer 1,5 tot 2 meter. Zelf vind ik het prettig om enige afstand te hebben. Ik voel me ongemakkelijk als een gesprekspartner steeds dichterbij komt. Als ik praat, wil ik het hele lichaam van mijn gesprekspartner kunnen zien. Ik vind non-verbale communicatie namelijk erg belangrijk.'

Ella beredeneert haar handelen ook uitgebreid met concepten op niveau 2. Zij beschrijft haar expressieve boodschap (betrokken en professioneel overkomen, er representatief uitzien, een zekere indruk maken) en beredeneert met concepten (oplossingsgericht handelen, non-verbale communicatie, mimiek, begrip tonen door knikken) hoe dit concreet tot uitdrukking komt in haar handelen. Ella toont met een dergelijke redenering een juist begrip van het concept expressieve boodschap en zij weet dit concept adequaat te concretiseren in handelingen.

'Expressieve boodschap: Tijdens het gesprek wil ik overkomen als een betrokken en professionele leerkracht. Ik wil er representatief uitzien, door nette kleding aan te doen. Ook wil ik dat de klas er netjes en verzorgd uitziet. Ik wil dat de ouder een professionele indruk van mij krijgen, door oplossingsgericht te handelen. Ik wil laten zien dat ik betrouwbaar, enthousiast en positief ben. Ik ben bereid leerlingen te helpen met problemen.

Tijdens het gesprek wil ik rekening houden met mijn non-verbale communicatie. Ik wil enthousiast overkomen en deze uitstraling met mijn lichaam en mimiek. Ook wil ik de ouder laten zien dat hij begrepen wordt. Af en toe een knikje geeft dit als bevestiging.

Verder wil ik een zekere indruk maken, door een stevige hand te geven. Een slappe hand geeft een teken van onzekerheid.'

Ten slotte wordt situatiespecifieke informatie in de voorbereiding beschreven zonder dat er gevolgen voor het handelen aan worden verbonden (niveau 1). Het gaat dan 
om informatie over het communicatiebeleid van de school, de vertrouwelijkheid van het gesprek en de verslaglegging. Deze informatie is relevant voor de situatie.

\section{Analyse}

In analyse 1 en 2 redeneert Ella met behulp van concepten over haar handelen (niveau 2). Bij gespreksfragment 1 grijpt Ella terug op de voorbereide relationele en expressieve boodschap. Beredeneerd wordt dat beide goed over het voetlicht zijn gekomen. In de gehele redenering worden concepten opgenomen (relationele boodschap, expressieve boodschap, social talk, zender, ontvanger). Een passend citaat van Steehouder (2006) over de expressieve boodschap is toegevoegd om de beschreven handelingen te onderbouwen.

Bij gespreksfragment 2 beschrijft Ella met behulp van concepten (afsluiting, zakelijke kern, samenvatten, communicatief doel) de inhoud van het gesprek en beredeneert ze vervolgens waarom ze ontevreden is over de afsluiting van het gesprek. $\mathrm{Zij}$ is vergeten een samenvatting te geven, hoewel ze dat een belangrijk gespreksonderdeel vindt. Verschillende argumenten worden gegeven voor het nut van een samenvatting (herhaling, check van communicatief doel, voorkomen dat gesprekspartners met verschillende ideeën uiteengaan over gespreksuitkomst, vervolgafspraken plannen). De gehele redenering wordt ondersteund door een citaat van Steehouder (2006) over samenvattingen van een gesprek.

'(...) Aan het eind van het gesprek ben ik vergeten het besprokene samen te vatten. Dit onderdeel is juist zo belangrijk, omdat op die manier alle punten worden herhaald. Het samenvatten van belangrijke punten geeft ook aan of alle onderwerpen aan de orde zijn geweest en of het communicatieve doel is bereikt. Verder is het samenvatten van gesprekspunten belangrijk om te voorkomen dat de ouder en ik uiteengaan met verschillende ideeën over de uitkomst van het gesprek.

Tevens kunnen er vervolgafspraken gemaakt worden tijdens de afsluiting. Ik geef wel aan dat de ouder altijd contact met mij mag opnemen. Dit is een punt wat ik wel belangrijk vind. Ouders kunnen altijd terecht voor vragen of opmerkingen.

'De beste manier van samenvatten is de besproken punten terug te halen, en de kernantwoorden te inventariseren die daarbij naar voren zijn gekomen. De meeste aandacht zal uiteraard uitgaan naar de conclusies (het bereikte akkoord, de gemaakte keuze, de gevonden oplossing), maar het is vaak goed ook nog eens samen te vatten langs welke weg die conclusie is bereikt.' Bron: Steenhouder M. Jansen C. Maat K. van der Staak J. de Vet D. Witteveen M. Woudstra E. (2006) blz. 306.'

Met de analyse als geheel laat Ella zien dat ze de communicatieve situatie weet te analyseren en daarbij concepten zinvol weet in te zetten.

\section{Perspectieven}

1. Perspectief ouder. In de voorbereiding heeft Ella herhaaldelijk oog voor het perspectief van de ouder. Zij leeft zich expliciet in het perspectief van de ouder in, benoemt het belang dat ouders hebben bij een goede communicatie en past haar handelen aan. In de formulering hanteert zij soms spontaan concepten (communicatief doel). Enkele voorbeelden van het innemen van het ouderperspectief: 
'Vooraf heb ik mij verplaatst in de vader van Linde. Dhr. T wil weten hoe het met zijn dochter gaat in groep 5 . Hij is benieuwd naar haar resultaten en sociale gedrag in de groep. Ook wil hij weten waarom het leesonderwijs niet verbeterd van zijn dochter.

Ik probeer mezelf met de ogen van Dhr. T te bekijken. Ik denk dat hij mij ziet als een jonge leerkracht die nieuwsgierig is naar zijn verhaal. Hij ziet mij als een gelijk persoon en voelt zich waarschijnlijk niet bedreigd. Mijn communicatieve doelen en die van mijn gesprekspartner zijn grotendeels complementair.'

'Het voeren van een tien-minuten-gesprek is voor de leerkracht, maar ook voor ouders erg belangrijk. De ouders willen weten hoe het gaat met hun zoon en/of dochter op school.'

'Ook wil ik de ouder laten zien dat hij begrepen wordt.'

In de analyse betrekt Ella ook herhaaldelijk het belang van de ouder. Een voorbeeld dat dit illustreert:

'Verder is het samenvatten van gesprekspunten belangrijk om te voorkomen dat de ouder en ik uiteengaan met verschillende ideeën over de uitkomst van het gesprek.'

2. Perspectief school. Ella betrekt in de voorbereiding het perspectief van de school door te citeren uit de schoolgids en te verwijzen naar het communicatiebeleid van de school. Het te voeren gesprek wordt in het geheel van het communicatiebeleid geplaatst, waarmee ook wordt verklaard dat ouder en leerkracht elkaar al kennen. Tevens wordt het door de school gewenste gedrag van de leerkracht beschreven:

'Binnen het communicatiebeleid op 'de Meander' staat beschreven dat de leerkracht zich open en professioneel moet opstellen naar ouders. Als er zaken zijn waarvan de leerkracht geen uitspraken mag doen, moet hij/zij de ouders doorverwijzen naar de directie'.

Door deze situatiespecifieke informatie op te nemen in haar voorbereiding laat Ella laat zien dat ze zich bewust is van het communicatiebeleid en van haar plaats in dat geheel.

\section{Conclusie}

Ella toont op verschillende manieren aan dat ze de conceptuele structuur beheerst. Dit blijkt enerzijds doordat zij in de voorbereiding de opdrachtgestuurde concepten juist hanteert en uitwerkt met een adequate selectie van subconcepten (niveau 1). Anderzijds blijkt dit doordat zij zowel in de voorbereiding als analyse spontaan relevante concepten betrekt, wat wijst op een uitgebreid gebruik van concepten. Kenmerkend is dat Ella deze concepten vooral hanteert op niveau 2, dat wil zeggen dat zij de concepten opneemt in redeneringen over het handelen. In het bijzonder de voorbereiding is inhoudelijk sterk: uiteenlopende aspecten van het gesprek worden concreet uitgewerkt in handelingen en beredeneerd. Met veelvuldig gebruik van citaten uit een geautoriseerde bron, waaruit ook haar aandacht voor het gebruik van concepten blijkt, zet zij haar beweringen kracht bij.

Het hoogste niveau van redeneren waarin situatiespecifieke informatie met concepten worden verbonden, laat Ella tweemaal zien in de voorbereiding (niveau 3). Zij selecteert situatiespecifieke factoren en maakt concepten betekenisvol voor haar handelen. Situatiespecifieke informatie, zoals het communicatiebeleid van de school, wordt soms alleen beschreven (niveau 1) en niet betrokken in een redenering.

Het perspectief van de ouders wordt consequent betrokken in de verantwoording. Ella geeft blijk van aandacht voor het belang van de ouder en past haar handelen hierop 
aan. Ook het perspectief van de school wordt betrokken door het communicatiebeleid te beschrijven.

Kortom, cognitieve flexibiliteit wordt in het geval van Ella overtuigend bereikt op het beoogde niveau. Typerend voor Ella is haar sterk conceptuele invalshoek. Het handelen wordt uitgebreid en nauwkeurig verantwoord in redeneringen met concepten die worden ondersteund met citaten uit een studieboek (niveau 2) - en in enkele gevallen gecombineerd met situatiespecifieke informatie (niveau 3). Bovendien krijgt het perspectief van de ouder consequent aandacht: het belang van de ouder wordt expliciet benoemd en het handelen wordt daarop afgestemd. Het perspectief van de school wordt door verwijzing naar formele bronnen ook betrokken, wat getuigt van organisatiebewustzijn.

\subsubsection{Vergelijking van goede gevallen}

De drie goede gevallen laten diverse overeenkomsten en enkele verschillen zien in de manier waarop hun cognitieve flexibiliteit zich manifesteert.

\section{Conceptuele structuur wordt beheerst en ook spontaan toegepast.}

Ten eerste tonen de goede gevallen aan dat ze de conceptuele structuur kennen en juist weten toe te passen. Dit blijkt uit het uitgebreide gebruik van concepten: naast de opdrachtgestuurde concepten worden ook spontaan concepten in ruime mate gehanteerd. De verdeling van de spontaan gehanteerde concepten is enigszins verschillend: Robijn en Ella nemen ze op in analyse en voorbereiding, Chery neemt er veel op in de analyse.

De kennis en juiste toepassing van de conceptuele structuur blijkt ook uit de diepgang waarmee de concepten worden gehanteerd. Ze worden inhoudelijk juist begrepen, met subconcepten uitgewerkt en consistent gebruikt. Kortom, er is sprake van een goede verankering van de concepten.

\section{Relevante situatiespecifieke informatie wordt geselecteerd.}

Ten tweede betrekken de goede gevallen relevante situatiespecifieke informatie in hun verantwoording, waarmee ze een juist begrip van de communicatieve situatie tonen. De soort situatiespecifieke informatie verschilt per definitie van geval tot geval, de mate waarin dergelijke informatie wordt betrokken verschilt enigszins: Robijn en Chery doen dit veel, Ella doet dit minder. Voor een deel kan dit verklaard worden door de gesprekssituatie zelf, voor een deel door de focus van de student. Bij Robijn is sprake van een afwijkend moment waarop het gesprek wordt gevoerd, bij Chery is sprake van een familierelatie met de ouders en is de verhouding met de mentor lastig. Deze situaties leiden sowieso tot situatiespecifieke informatie die van invloed is op de gesprekssituatie én beide studenten hebben oog voor andere relevante factoren. Bij Ella is de situatie gangbaarder en bovendien heeft zij een sterk conceptuele benadering van de situatie. Hoewel de mate waarin situatiespecifieke situatie wordt betrokken in de verantwoording dus enigszins verschilt, wordt een 
juist begrip van verschillende aspecten van de communicatieve situatie in alle gevallen getoond.

Verantwoording bestaat hoofdzakelijk uit redeneringen van niveau 2 en 3; handelen wordt op situatie afgestemd.

Ten derde vertonen de goede gevallen een overeenkomst in de wijze waarop zij beide bovengenoemde elementen - concepten en situatiespecifieke factoren-, betrekken in hun verantwoording. De verantwoordingen bestaan hoofdzakelijk uit redeneringen over het handelen met concepten en/of situatiespecifieke informatie van niveau 2 en 3. De goede gevallen weten situatiespecifieke informatie en concepten met elkaar in samenhang te brengen (niveau 3), maar ook situatiespecifieke informatie en concepten los van elkaar te betrekken in redeneringen (niveau 2). Zo wordt in voorbereiding 1 niet alleen voldaan aan het door de opdracht gevraagde niveau 1, maar worden daarin ook redeneringen van niveau 2 en 3 geïntegreerd. In voorbereiding 2 wordt het gevraagde niveau 3 bereikt, maar worden ook redeneringen van niveau 2 toegevoegd. Hoewel in alle drie gevallen ook situatiespecifieke informatie uitsluitend wordt beschreven (niveau 1), gebeurt dit in beperkte mate. Het betreft informatie die ter zake doet en een beeld schetst van de bredere context waarin het gesprek plaatsvindt. Niet alleen de voorbereiding, maar ook de analyse wordt gekenmerkt door redeneringen van niveau 2 en 3. Gevraagd wordt te redeneren met concepten (niveau 2). Dit vindt plaats en in twee gevallen wordt bovendien met situatiespecifieke informatie geredeneerd (niveau 3 en 2).

Kortom, de goede gevallen blijken in staat - ook wanneer de opdracht er niet om vraagt - hun handelen te motiveren met situatiespecifieke informatie en concepten. Robijn, Chery en Ella blijken tevens hun handelen op de situatie af te stemmen en zijn in staat dat handelen concreet en nauwkeurig te formuleren.

Perspectiefwisseling vindt plaats; innemen ouderperspectief vindt consequent plaats en krijgt concrete uitwerking op handelingsniveau; innemen schoolperspectief en concrete uitwerking varieert.

Ten vierde laten de goede gevallen perspectiefwisseling zien. Het perspectief van de ouders wordt consequent ingenomen: het belang van de ouders, hun mogelijke emoties en het besef dat een positieve relatie met de ouders wenselijk is in het belang van het kind worden herhaaldelijk uitgedrukt. De gespreksvoorbereiding en de analyse zijn bovendien doordesemd van het inzicht dat iedere communicatieve handeling effect heeft op de gesprekspartner. Dit inzicht heeft ook gevolgen op handelingsniveau en wordt concreet vormgegeven in het communicatieve handelen. In twee gevallen wordt ook het perspectief van de school ingenomen. Ella en Robijn refereren beide aan het schoolbeleid en citeren relevante passages uit een formele bron, waarmee de bredere context van oudercontacten op de betreffende basisschool wordt geschetst en organisatiebewustzijn wordt getoond. Robijn stemt ook haar handelen af op het schoolbeleid; zij blijkt in staat als beginnend professional bewust 
te handelen in overeenstemming met het belang van de organisatie. Opvallend is dat in de verantwoording van Chery het schoolperspectief ontbreekt.

Ten slotte is een wezenlijk kenmerk van deze gevallen de samenhang tussen de verschillende bovengenoemde elementen:

1. een adequaat geïnterpreteerd en ook spontaan toegepaste conceptuele structuur

2. relevante situatiespecifieke informatie over diverse aspecten van de communicatieve situatie

3. redeneringen over het handelen met concepten en situatiespecifieke informatie op niveau 2 en 3

4. perspectiefwisseling (met accent op het ouderperspectief).

Het beoogde niveau van cognitieve flexibiliteit (waarin het handelen met concepten, situatiespecifieke informatie én inachtneming van verschillende perspectieven wordt beredeneerd) wordt niet alleen bereikt, maar is van hoge kwaliteit doordat de afzonderlijke elementen van hoog niveau zijn en goed met elkaar in verband worden gebracht.

\subsubsection{Duiding van zes voldoende gevallen}

\section{Duiding van geval 4: Lara Voorbereiding}

In voorbereiding 1 beschrijft Lara de opdrachtgestuurde concepten juist en consistent (niveau 1). Minder sterk is dat de gespreksopbouw inhoudelijk beperkt wordt uitgewerkt en dat subconcepten niet worden gebruikt. Daarnaast beschrijft zij situatiespecifieke informatie over de gebruikelijke werkwijze van de school: ze beschrijft welke gesprekken normaliter worden gevoerd met de ouders van de combinatiegroep 7-8 en hoe het door haar gevoerde 10-minutengesprek past in die reeks (niveau 1). Deze informatie geeft een goed beeld van de formele contacten met ouders.

In voorbereiding 2 beredeneert Lara met behulp van situatiespecifieke informatie (over de schoolcultuur en haar eigen contact met de ouder) hoe ze het concept relationele boodschap gaat vormgeven (niveau 3). Dit wordt als volgt uitgedrukt

'Relationele boodschap: Op school is het gewoonlijk dat ouders worden aangesproken met de voornaam en 'jij'. Dit is de eerste keer dat ik een gesprek voer. Toch kies ik ervoor om de gewoontes van de school op te volgen. Als lio-er wil je er graag tussen horen en probeer je je te mengen in het team en de school. Ouders zijn niet gewend om met 'mevrouw' of 'meneer' aangesproken te worden. De ouder van Jouke heb ik al een paar keer gesproken op school en heb andere gesprekken bijgewoond wanneer mijn mentor het woord voerde.'

Lara laat hiermee zien dat ze het concept relationele boodschap samenhangend kan verbinden aan de situatie en haar handelen weet aan te passen aan de situatie.

Verder redeneert Lara met een concept over haar handelen (niveau 2). Ze geeft een adequate interpretatie van het concept expressieve boodschap ('positief opstellen en 
geloofwaardig overkomen') en beredeneert hoe ze aan die positieve opstelling en geloofwaardigheid wil vormgeven in haar handelen.

'Expressieve boodschap: Mijn rol is om informatie te verschaffen over Jouke, het is een oudergesprek. Daarbij vind ik het belangrijk dat ik mij positief opstel. Ouders zijn heel trots en hebben het beste voor met hun kind. Als leerkracht moet je dus 'oppassen' met wat je zegt en hoe het over komt op de ouders.

Ook wil ik geloofwaardig overkomen op de ouders. Tijdens het gesprek heb ik het rapport en andere resultaten bij de hand. Zo kunnen ouders ook meekijken en weten ze dat het echt is.'

Ten slotte beschrijft Lara situatiespecifieke informatie, over de moeder, de mentor en de ruimtelijke opstelling (niveau 1). Deze informatie is relevant voor de gesprekssituatie, maar Lara verbindt hieraan geen conclusies voor haar handelen. In een voorbeeld hiervan wordt beschreven dat de ouder meer kinderen op de school heeft (gehad) en daardoor bekend is met oudergesprekken en met de mentor:

'Het gesprek gaat over Jouke en wordt gevoerd met haar moeder (Esther). Jouke is de jongste van vier dochters. Haar zus D. zit nog in groep 8, dezelfde groep dus. De andere twee zussen zitten op het voorgezet onderwijs, maar hebben wel bij Thijs (mijn mentor) in de klas gezeten. Thijs heeft dus al veel gesprekken met Esther gevoerd over haar kinderen. Ook is Esther erg betrokken bij de school, ze is overblijfmoeder en helpt vaak bij activiteiten die op de school plaatsvinden.'

\section{Analyse}

Lara betrekt in analyse 1 één concept (ruimte geven) bij de korte beschrijving en beoordeling van haar communicatief handelen (niveau 2). Zij is er tevreden over dat ze de moeder ruimte geeft om te reageren, aangezien ze in haar voorbereiding interactiviteit als aandachtspunt had.

In analyse 2 betrekt Lara ook één concept (doorvragen) bij de beschrijving en negatieve beoordeling (niveau 2). Ze beredeneert waarom het niet goed was dat zij maar kort op het onderwerp inging en beschrijft vervolgens een handelingsalternatief :

'Wanneer ik het gesprek nu terug zie, had ik het daar anders willen doen. Ik had daar langer bij stil moeten staan. Het is toch wel een belangrijk punt dat we goed naar ouders moeten uitleggen. Later in het gesprek zie je ook dat moeder er op terug komt. Dit had ik natuurlijk niet vooruit kunnen weten. Wel had ik er op het begin langer bij stil kunnen staan. Ik had bijvoorbeeld bij moeder kunnen doorvragen hoe zij dit ziet en of dit buiten school ook gebeurt.'

In de analyse als geheel wordt geredeneerd, maar hierbij worden weinig concepten betrokken.

\section{Perspectieven}

1. Perspectief ouder. In de voorbereiding betrekt Lara herhaaldelijk het perspectief van de ouder en past zij haar handelen hierop aan. Zo tutoyeert zij de ouders:

'(...) omdat zij niet gewend zijn met mevrouw of meneer aangesproken te worden.'

Uit diverse formuleringen blijkt dat zij zich bewust is van de positie van ouders en het gezamenlijke belang van ouder en leerkracht. Een voorbeeld hiervan: 
'Daarnaast vind ik het ook belangrijk om de ouders de ruimte te geven om te reageren en hun eigen opvattingen te delen. Kinderen kunnen zich op school heel anders gedragen dan op school. De ouders zijn de eerste opvoeders. Leerkrachten kunnen dus hun handelen afstemmen op de behoeften van het kind. Het is ook belangrijk dat je echt naar de ouders luistert en ze serieus neemt.'

Ook in de analyse komt het perspectief van de ouder aan bod. Lara kijkt in beide fragmenten terug naar haar persoonlijke aandachtspunt (ruimte geven, luisteren, serieus nemen) dat is gericht op de ouder.

'Hiermee laat ik zien dat ik oprecht geïnteresseerd ben in de thuissituatie en de mening van de ouders.'

2. Perspectief school. Lara betrekt het perspectief van de school in haar voorbereiding door de gang van zaken met betrekking tot formele gesprekken te beschrijven. Ze beschrijft welke gesprekken door de school worden gevoerd met de ouders van de combinatiegroep 7-8 en hoe het gevoerde 10-minutengesprek past in die reeks. Dit wordt niet gerelateerd aan het communicatiebeleid en er wordt geen bron vermeld.

\section{Conclusie}

Lara's gebruik van de conceptuele structuur laat een wisselend beeld zien: de opdrachtgestuurde concepten worden juist gehanteerd, maar spontaan worden in de analyse nauwelijks concepten gehanteerd.

Het handelen in voorbereiding en analyse wordt verantwoord in redeneringen op niveau 2 en eenmaal op niveau 3.

In de voorbereiding wordt veel situatiespecifieke informatie betrokken, waarmee een goed beeld van de situatie wordt geschetst. Een deel van deze informatie wordt betrokken in redeneringen en betekenisvolgemaakt voor het handelen (niveau 2 en 3), een ander deel wordt beschreven (niveau 1). Lara blijkt relevante informatie voor een goed begrip van de situatie te kunnen selecteren, maar weet deze niet altijd te verbinden aan haar handelen.

Lara betrekt het perspectief van de ouders herhaaldelijk in haar voorbereiding en analyse en laat blijken haar handelen aan te passen aan haar gesprekspartner. Ze benadert de ouders als gelijkwaardige gesprekspartners en houdt rekening met hun (mogelijke) gevoelens. Het perspectief van de school wordt betrokken door de gang van zaken met betrekking tot formele gesprekken op een concreet niveau te beschrijven.

Kortom, Lara bereikt het beoogde niveau van cognitieve flexibiliteit. Zij blijkt in staat haar handelen te beredeneren, waarbij ze situatiespecifieke informatie en concepten verbindt (niveau 3) of een van beide elementen betrekt (niveau 2). Zij heeft oog voor factoren die de situatie beïnvloeden en past haar handelen aan. Ook vindt perspectiefwisseling plaats. Het perspectief van de ouder wordt nadrukkelijk ingenomen en heeft gevolgen voor het handelen en het perspectief van de school wordt op een concreet niveau beschreven.

Hoewel het beoogde niveau bereikt is, kent de getoonde cognitieve flexibiliteit ook enkele beperkingen: Het spontane gebruik van concepten is beperkt en een deel van 
de situatiespecifieke informatie is wel beschreven, maar niet betekenisvol gemaakt voor het handelen.

\section{Duiding van geval 5: Desi Voorbereiding}

Desi beschrijft de concepten in voorbereiding 1 juist en consistent (niveau 1). Het concept gespreksopbouw wordt hierbij inhoudelijk summier uitgewerkt zonder subconcepten te noemen. Daarnaast beschrijft Desi situatiespecifieke informatie over de gezamenlijke gespreksvoorbereiding met haar mentor en beredeneert ze welk positief gevolg de voorbereiding heeft voor de communicatie (niveau 2).

' (...) Vervolgens heb ik de voorbereidingsformulieren ingevuld voor de gesprekken. Mijn mentor heeft ze ook ingevuld en naar mij opgestuurd, zodat we wel dezelfde punten zouden hebben. Dit bleek sowieso al heel erg op een lijn te liggen. Ik heb een leeg voorbereidingsformulier bijgevoegd als bijlage. Hierop vullen we de gegevens van de betreffende leerling in en bijzonderheden die we willen bespreken. Hierdoor hoeven we zelf niet telkens in het rapport te kijken en kunnen we dat gewoon naar de ouders toe draaien. '

Later komt Desi op het belang van gespreksvoorbereiding terug en betrekt zij situatiespecifieke informatie en een concept (oogcontact) in een redenering over haar handelen (niveau 3):

'Vooraf wilde ik goed voorbereid zijn. Ik heb het voorbereidingsformulier goed doorgenomen en gezorgd dat ik op de hoogte was van de vorderingen van de leerling. Ik wilde voorkomen dat ik niet alles wist van deze leerling. Ook heb ik mijn mentor nog gevraagd hoe het ging met deze leerling tijdens de dyslexiebegeleiding. (Dit is nu gestopt, maar was elke week op vrijdagochtend na de pauze). Tijdens het gesprek vind ik het belangrijk dat ik de ouder aankijk. Ik wilde niet telkens naar het papier moeten staren. Oogcontact vind ik belangrijk.'

In voorbereiding 2 betrekt Desi het concept expressieve boodschap in een redenering over haar handelen (niveau 2):

'De expressieve boodschap is meer hoe ik de boodschap overbreng. Ik wil het op een positieve manier overbrengen en zou dit bijvoorbeeld met een persoonlijke anekdote kunnen benadrukken. Hierbij laat je eigenlijk iets meer van jezelf zien.'

Desi gebruikt het concept expressieve boodschap en concretiseert het in haar handelen. Een ander concept (relationele boodschap) wordt weliswaar beschreven, maar wordt niet geconcretiseerd in het handelen. Niet duidelijk wordt wat de relationele boodschap inhoudt en hoe 'rekening houden met' vorm krijgt (niveau 1).

'Mijn relationele boodschap is meer gericht op de ouder. Ik houd hierbij rekening met hoe ik denk dat de ouder zal reageren op de boodschap. De leerling scoort niet goed voor spelling, omdat hij dyslectisch is. Omdat hij wel goed kan leren, scoort hij wel goed voor werkwoordspelling. Hij kan daardoor goed regels toepassen.'

Verder beschrijft Desi relevante informatie over drie situatiespecifieke aspecten: de situatie van de moeder, de voorafgaande situatie met betrekking tot het kind en over de ruimtelijke opstelling van de stoelen en tafels (niveau 1). Deze informatie draagt bij aan een goed beeld van de gesprekssituatie. Een voorbeeld: 
'Er is een gesprek geweest met de IB'er. Ook is er een handelingsplan voor lezen gemaakt. De ouders zijn hiervan op de hoogte en de leerling heeft ook extern nog begeleiding voor de dyslexie. Ouders begrijpen de situatie goed en begeleiden de leerling thuis ook.'

Hiermee laat Desi zien dat zij relevante situatiespecifieke informatie weet te selecteren. Aan die informatie verbindt zij geen conclusies voor haar handelen.

\section{Analyse}

In analyse 1 beschrijft Desi haar communicatief handelen met één subconcept (informatie overbrengen) en beredeneert ze kort waarom het goed was (niveau 2).

'Een punt dat volgens mijn mentor goed ging was mijn duidelijkheid. Ik vroeg voor ik verder ging van bijvoorbeeld de cito-resultaten naar de rest van het rapport ook telkens of alles duidelijk was of dat de ouders nog vragen hadden over dit deel. (2.20 in het filmpje). Ik zei dan ook dat ik daarna over zou gaan naar het rapport zelf. Je wilt informatie overbrengen op ouders, dus ik ben blij dat ik dit wel duidelijk heb gedaan.'

In analyse 2 beschrijft en beredeneert zij waarom tijdsbewaking belangrijk is op een ouderavond en formuleert ze met twee subconcepten (samenvatten, afsluiten) een handelingsalternatief (niveau 2):

'Een punt waar ik echt op moet letten is de tijd. Vooral in dit geval, want je hebt echt maar tien minuten voor elk gesprek. Ouders hebben de neiging om door te kletsen en ik ga daar zelf ook te veel op in. Op een gegeven moment moet ik eerder vragen of alles duidelijk is, en dingen kort samenvatten. Hiermee sluit ik het gesprek dan af. Er zitten immers ook andere mensen op de gang te wachten. Mijn mentor zei wel dat ze dit zelf ook lastig vindt, maar dat ik hier ook op moet letten.'

De beide analyses zijn kort en betreffen inhoudelijk één aspect van de communicatie, de gespreksvaardigheden.

\section{Perspectieven}

1. Perspectief ouder. Het perspectief van de ouders wordt in de voorbereiding betrokken. Desi wil rekening houden met de persoonlijke omstandigheden van de moeder en met de mogelijke gevoelens van de ouders. Hoe zij haar handelen hierop aanpast, wordt niet duidelijk.

'Bij dit gesprek is alleen de moeder aanwezig. Zij is altijd erg betrokken bij alles wat er gebeurt op school. Op het moment van het gesprek is haar vader ernstig ziek. Hier houd je automatisch rekening mee tijdens het gesprek.'

'Ik houd hierbij rekening met hoe ik denk dat de ouder zal reageren op de boodschap.'

In de analyse wordt het perspectief van de ouders ook betrokken, ditmaal vanuit praktisch oogpunt: de 10-minutengesprekken mogen niet uitlopen, want dat is vervelend voor de andere ouders. Concreet wordt geformuleerd welk gedrag daarbij passend is.

'Op een gegeven moment moet ik eerder vragen of alles duidelijk is, en dingen kort samenvatten. Hiermee sluit ik het gesprek dan af. Er zitten immers ook andere mensen op de gang te wachten.'

Geen aandacht wordt besteed aan de beleving van de ouders gedurende het gesprek. Zowel in de voorbereiding als in de analyse ligt de nadruk op het perspectief van de 
leerkracht en de vraag 'Doe ik het goed?' Belangrijk voor Desi is het oordeel van haar mentor die voor haar geldt als een rolmodel.

2. Perspectief school. Het perspectief van de school wordt niet betrokken in de verantwoording. Desi conformeert zich aan de werkwijze van haar mentor en beschrijft deze concreet, maar zij legt geen relatie met de gang van zaken rondom formele gesprekken op de basisschool of het communicatiebeleid.

\section{Conclusie}

Desi laat een gedifferentieerd beeld zien in het gebruik van concepten. Enerzijds laat ze zien dat ze enkele opdrachtgestuurde concepten juist gebruikt en dat ze spontaan concepten gebruikt. Dit wijst op een zekere beheersing van concepten. Anderzijds hanteert ze één opdrachtgestuurd concept onjuist en geeft ze aan een ander opdrachtgestuurd concept een summiere inhoudelijke invulling, wat juist weer wijst op een beperkte beheersing van de concepten. Kortom, de conceptuele structuur wordt deels beheerst en toegepast.

De voorbereiding bevat een mix van redeneringen en beschrijvingen, dat wil zeggen dat Desi haar handelen deels verantwoordt in redeneringen en deels niet. Zowel concepten als situatiespecifieke informatie worden op verschillende niveaus gehanteerd (niveau 1, 2 en 3). Desi beschrijft vrij veel relevante situatiespecifieke informatie en laat hiermee zien oog te hebben voor de situatie. In één geval weet Desi informatie over haar gespreksvoorbereiding in een redenering te verbinden met een concept (niveau 3). Aan de overige situatiespecifieke informatie worden geen gevolgen voor het handelen verbonden (niveau 1).

De analyse is kort en bevat redeneringen met enkele concepten (niveau 2) en in inhoudelijk beperkt.

Verder betrekt Desi het perspectief van de ouder in haar voorbereiding en analyse. Het accent ligt echter duidelijk op het leerkrachtperspectief en op de vraag 'Doe ik het goed?', waarbij het oordeel van de mentor voor haar belangrijk is. Het ouderperspectief wordt in de analyse in beperkte mate geconcretiseerd in haar handelen. Het perspectief van de school wordt niet betrokken in haar verantwoording.

Vastgesteld wordt dat de cognitieve flexibiliteit die Desi toont, sterke en zwakke elementen kent. Zij bereikt het beoogde niveau van cognitieve flexibiliteit, aangezien zij haar handelen verantwoordt in redeneringen op niveau 2 en eenmaal op niveau 3. Bovendien is er sprake van perspectiefwisseling: ze betrekt het perspectief van de ouder in haar verantwoording. Er valt wel iets af te dingen aan de kwaliteit van beide onderdelen. De concepten worden niet foutloos gehanteerd, en concepten en situatiespecifieke informatie worden niet altijd betekenisvol gemaakt voor het handelen (niveau 1). Beperkte kwaliteit geldt ook voor de perspectiefwisseling: Desi toont wel empathie voor de ouder, maar het wordt in beperkte mate concreet hoe die empathie in concrete communicatieve handelingen tot uiting komt. 


\section{Duiding van geval 6: Veerle Voorbereiding}

In voorbereiding 1 beschrijft Veerle de opdrachtgestuurde concepten juist en consistent, hoewel ze het concept gespreksopbouw niet uitwerkt met subconcepten. Ze beschrijft daarnaast situatiespecifieke informatie en legt uit waarom de school het adviesgesprek over voortgezet onderwijs voert voordat de cito-scores bekend zijn. Deze informatie is relevant voor een goed begrip van de gesprekssituatie. Veerle laat zien concepten juist te kunnen beschrijven en relevante situatiespecifieke informatie te kunnen selecteren (niveau 1).

In voorbereiding 2 redeneert Veerle over haar handelen met behulp van concepten en met situatiespecifieke informatie (niveau 2). Ze betrekt de opdrachtgestuurde concepten relationele en expressieve boodschap in redeneringen over haar handelen. Ze interpreteert deze concepten juist en beredeneert hoe ze die kan vormgeven. Een voorbeeld:

'Relationele boodschap: ik heb een open houding en ik zorg voor rust tijdens het gesprek, zodat er een wisselwerking tussen ouder en leerkracht mogelijk is. Ik creëer een respectvolle en veilige situatie door de open houding en de rust, zodat de ouder zich veilig voelt en zich serieus genomen voelt.'

Haar expressieve boodschap beschrijft ze uitgebreid in termen van gespreksvaardigheden, hoewel ze haar expressieve boodschap niet in abstracto formuleert.

'Expressieve boodschap: deze boodschap heeft te maken met mijn expressiviteit, mijn benadering en presentatie. Bij de begroeting loop ik naar de deur om de ouder(s) een hand te geven en aan het einde van het gesprek bedank ik de ouder(s) voor hun tijd en loop weer mee naar de deur. Tijdens het gesprek zorg ik voor een actieve luisterhouding (iets voorovergebogen zitten), voor oogcontact en voor een open houding (handen liggen op tafel)'.

Situatiespecifieke informatie over de ouders wordt ook betrokken in een redenering over het handelen. Veerle geeft relevante informatie over de ouders (indruk bestaat dat de ouders het niveau van zoon te hoog inschatten). Zij beredeneert vervolgens welk gedrag passend is bij het geven van het advies (ouder serieus nemen, wel achter advies staan, maar ook benadrukken dat de school adviseert en de ouders beslissen).

'Het is een ouder die een positieve kijk heeft op de school en waarmee een goed contact wordt onderhouden. Een algemeen beeld door de jaren heen is dat de ouders J. naar het idee van de leerkrachten te hoog inschatten, zo blijkt ook uit de resultaten. De ouders zijn beiden hoog opgeleid en denken dat J. ook een hoog niveau heeft. Toch komt dat er bij J. niet helemaal uit.'

'(...) Ik wil de ouder serieus nemen in wat hij vertelt over J. Ik sta natuurlijk achter mijn advies, maar ik wil ook benadrukken dat ik (en de school) een advies geven en dat de ouders het verder maar moeten uitzoeken. Ik wil samen met de ouders tot een goed en passend advies komen.'

Hiermee toont Veerle aan dat ze situatiespecifieke informatie betekenisvol weet te verbinden aan haar handelen en dat ze haar handelen weet aan te passen aan de situatie. Ten slotte beschrijft Veerle nog situatiespecifieke informatie over uiteenlopende aspecten (over de werkwijze van de school, haar voorbereiding op het 
gesprek, de ruimtelijke opstelling van tafels en stoelen). Deze informatie is relevant, maar Veerle verbindt er geen consequenties aan voor haar communicatieve gedrag (niveau 1).

\section{Analyse}

In analyse 1 beredeneert Veerle met behulp van situatiespecifieke informatie (ouder schat niveau kind hoger in; ouder en student hebben nog niet eerder een gesprek gevoerd) en concepten (oriëntatiefase, gespreksopbouw, actieve luisterhouding, ruimte geven) waarom haar communicatieve gedrag goed was. Ze verantwoordt haar handelen dus met redeneringen op niveau 3 . Een voorbeeld:

'Het uiteindelijke advies verliep goed. Ik had al het idee dat de ouder J. hoger in zou schatten dan het reële niveau van J., maar ik wist zelfverzekerd mijn argumenten uit te leggen (vanaf 3 min.). Daarnaast verliep de oriëntatiefase van het gesprek goed. De ouder heeft mij wel eerder gezien, want ik heb er met het vorige 10-minutengesprek bijgezeten en geluisterd. Hij heeft echter nog geen gesprek met mij gevoerd. Ik pas fase 1 en 2 van gespreksopbouw toe. Ik begin door te vragen of $i k$ het gesprek op mag nemen en vervolgens door te vragen hoe het met J. gaat. Hij is namelijk ziek is geweest. Het doel van deze vraag is om het ijs tussen mij en de ouder te breken (...).'

Analyse 2 is minder uitgebreid. Veerle beschrijft met behulp van twee concepten (kern, doorvragen) dat het communicatieve doel is behaald, maar dat het gesprek interactiever had kunnen verlopen, een persoonlijk doel (niveau 2). Zij benoemt een handelingsalternatief, namelijk vragen naar argumenten en doorvragen.

\section{Perspectieven}

1. Perspectief ouder. In de voorbereiding betrekt Veerle het perspectief van de ouder herhaaldelijk en expliciet en past haar handelen hierop aan. Een voorbeeld hiervan:

'Ik heb van tevoren de opzet van het adviesgesprek met mijn mentor doorgenomen. Daar komt toch wel uit dat ik zelf veel aan het woord ben, omdat ik veel uit moet leggen voordat $i k$ tot een gegrond advies kan komen. Toch wil ik de ouder gelegenheid geven om over J. te praten en ik wil de ouders de mogelijkheid geven om vragen te stellen. J. is het oudste kind uit het gezin, dus de ouders zijn nog niet bekend met het voortgezet onderwijs. Alles is nieuw en ik kan me voorstellen dat er dan best wel veel op je afkomt (als ik het vanuit het oogpunt van de ouders bekijk).'

In de analyse wordt het perspectief en het belang van de ouder ook betrokken. Dat uit zich op de volgende wijze:

'Het doel van deze vraag is om het ijs tussen mij en de ouder te breken.'

'Als ik aan het woord ben, probeer ik ruimte in te lassen zodat de ouder kan reageren.'

2. Perspectief school. Het perspectief van de school wordt betrokken in de voorbereiding doordat Veerle de functie en het doel van het adviesgesprek beschrijft.

'De school voert over elke leerling een adviesgesprek met de ouder(s). Dat advies wordt ook aan de middelbare school voorgelegd.'

'De school heeft er bewust voor gekozen om het advies voor het voortgezet onderwijs te geven voordat de CITO score bekend is. Aan de ene kant is dat een nadeel, want ik kan geen statistische gegevens op papier laten zien. Aan de andere kant kan het beeld van het 
kind niet veranderen door een CITO score. Het kind heeft de afgelopen acht jaar een niveau laten zien en de school wil graag een reëel beeld van het kind aan de ouder laten zien.'

Veerle relateert deze informatie niet expliciet aan het schoolbeleid, maar uit de citaten blijkt dat zij zich bewust is van de motivatie van de school voor de gekozen aanpak en van de functie van het gesprek.

\section{Conclusie}

Veerle geeft blijk van beheersing van de conceptuele structuur. In de voorbereiding hanteert zij de opdrachtgestuurde concepten juist en in de analyse hanteert zij een aantal 'spontane' concepten juist.

In de voorbereiding verantwoordt ze haar handelen met redeneringen waarbij ze ofwel concepten ofwel situatiespecifieke informatie betrekt (niveau 2). Ze laat zien situatiespecifieke informatie en concepten betekenisvol te kunnen maken voor haar eigen handelen. In de analyse verantwoordt ze haar handelen ook met redeneringen waarin beide elementen samenhangend worden betrokken (niveau 3). Niet altijd wordt situatiespecifieke informatie betrokken in een redenering. De voorbereiding bevat ook informatie die alleen wordt beschreven (niveau 1).

Veerle betrekt in de verantwoording herhaaldelijk het perspectief van de ouders en past haar handelen daarop aan. Typerend is dat Veerle in de voorbereiding blijk geeft van een goed begrip van de mogelijke conflictsituatie waarin ze kan terechtkomen. Ofschoon zij weet dat de ouders waarschijnlijk het advies voor vervolgonderwijs gaan betwisten, neemt zij een professionele houding aan: zij wil het advies gedegen met resultaten onderbouwen, maar tegelijkertijd de ouders serieus nemen en ' $t$ liefst tot consensus komen. $\mathrm{Zij}$ doet aan een vorm van belangenafweging, waarin het perspectief van de ouder en van de school worden betrokken. Haar voorbereiding is doorspekt van redeneringen waarin respect voor de ouders meeklinkt. Ook het perspectief van de school betrekt zij in zekere mate door haar eigen advies te beschouwen als een advies van 'de school' en door een beschrijving te geven van de functie en het doel van het adviesgesprek. Zij verwijst niet naar formele bronnen omtrent schoolbeleid.

Veerle bereikt het beoogde niveau van cognitieve flexibiliteit. Zij blijkt in staat situatiespecifieke informatie en concepten te hanteren in redeneringen over haar handelen die zich hoofdzakelijk op niveau 2 en soms op niveau 3 bevinden. Haar verantwoording kenmerkt zich verder door een goed begrip van de mogelijk conflictueuze situatie en een professionele houding hierin, waarin het perspectief van de ouder herhaaldelijk en dat van de school in zekere mate wordt betrokken. Concepten worden niet altijd met subconcepten uitgewerkt.

\section{Duiding van geval 7: Britta Voorbereiding}

Britta beschrijft de opdrachtgestuurde concepten in voorbereiding 1 consistent. De uitwerking van de concepten vertoont enige beperking: het communicatieve doel 
wordt deels met onjuiste terminologie beschreven en het concept gespreksopbouw wordt niet met subconcepten uitgewerkt. Hiermee laat Britta zien dat ze de concepten wel in hoofdlijnen, maar niet in detail beschrijft (niveau 1).

In voorbereiding 2 betrekt Britta situatiespecifieke informatie en concepten in redeneringen over haar handelen (niveau 3). Zo noemt ze kenmerken van de ouders (beschermend, vinden mening leerkracht belangrijk) en verbindt hieraan haar eigen relationele boodschap (ouder is gelijk aan leerkracht, samen doen, samen beslissen). Ook geeft ze kort aan hoe ze die boodschap vormgeeft (uitspreken). Ter illustratie:

'Het is belangrijk om rekening te houden met bepaalde relevante kenmerken van de ouders. Bij deze ouders is het belangrijk om rekening te houden met het feit dat zij erg beschermend zijn. Zij komen regelmatig vragen hoe het met de leerling gaat, of zij zich fijn voelt in de klas, vriendjes/vriendinnetjes heeft. Daarnaast vinden zij de mening van de leerkracht belangrijk. Er wordt regelmatig naar de mening van de leerkracht gevraagd. Mijn relationele boodschap in dit gesprek is dat ik de mening van de ouders net zo belangrijk vind als mijn eigen mening. De ouders zijn dus gelijk aan mij, de leerkracht. Samen moeten we het doen en samen moeten we tot een beslissing komen. Ik zal dit zeker uitspreken naar de ouders.'

De relationele boodschap wordt ook gemotiveerd met het beleidsdoel van de school:

'Ik heb geen beleidsdoel, maar het welkom voelen, het er toe doen zou een beleidsdoel kunnen zijn. De school wil graag laagdrempelig zijn en niet uitstralen van "wij weten het toch beter". Uitgangspunt is: onderwijs maak je samen, ook met ouders.'

Britta laat zien dat zij haar relationele boodschap een op de situatie toegesneden invulling weet te geven en haar handelen aan de situatie kan aanpassen. Het gebruik van concepten is wisselend van kwaliteit: sterk is dat zij het concept beleidsdoel spontaan hanteert, zwak is dat er geen onderscheid is gemaakt tussen de relationele en expressieve boodschap.

Andere situatiespecifieke informatie die bijdraagt aan een goed begrip van de situatie (over een voorgaand gesprek en over de gespreksopstelling) wordt alleen beschreven (niveau 1). Britta is in staat relevante informatie te selecteren, maar verbindt hieraan geen gevolgen voor haar handelen.

\section{Analyse}

In analyse 1 wordt het handelen juist geanalyseerd met behulp van concepten (samenvatten, referentiële, relationele en expressieve boodschap). De gespreksvaardigheden worden positief gewaardeerd in het licht van de voorbereiding, omdat de bedoelde 'boodschappen' goed uit de verf komen (niveau 2). In analyse 2 betrekt Britta situatiespecifieke informatie en concepten in een redenering over haar handelen (niveau 3). Ze beschrijft haar communicatieve gedrag in dit fragment ('Ik vraag met een verkeerde ondertoon naar de mening van de ouders') en beredeneert op basis van situatiespecifieke informatie over de ouders waarom dit niet goed is. Dit brengt ze vervolgens ook in verband met haar bedoelde expressieve en relationele boodschap. Zij drukt dit als volgt uit:

'Ik vraag aan de ouder: "Maar nog een jaar kleuteren, denken jullie dat Pascalle daar gelukkig van wordt? Ik vraag met een verkeerde ondertoon naar de mening van de ouders.

De manier waarop ik de vraag stel, geeft al aan in welke richting ik denk, wat ik de juiste 
oplossing vind. Dit terwijl ik juist graag van de ouders wil weten hoe zij daar over denken en ik hierbij rekening moest houden met het feit dat zij de mening van de leerkracht erg belangrijk vinden, dat was namelijk één van relevante kenmerken van de ouders. Mijn expressieve boodschap is dat ik de ouders wil laten merken dat zij er toe doen, dat ik opensta voor hun mening. Met een opmerking als in het gemarkeerde stuk tekst, laat ik de ouders niet merken dat ik opensta voor hun mening. Mijn relationele boodschap is dat ik de mening van de ouders net zo belangrijk vind als mijn eigen mening, maar met deze ondertoon laat ik merken dat ik het niet eens ben met wat zij zeggen. De opmerking komt dus zowel mijn expressieve als relationele boodschap niet ten goede.'

\section{Perspectieven}

1. Perspectief ouder. Britta betrekt het perspectief van de ouder met name in haar relationele en expressieve boodschap. Daarin wordt herhaaldelijk en expliciet duidelijk gemaakt dat de mening van de ouders gerespecteerd wordt, gelijkwaardig is aan die van de leerkracht, en dat leerkracht en ouder samen tot beslissingen komen. Zowel in de voorbereiding als in de analyse van het gesprek wordt op dit aspect de nadruk gelegd. In de analyse wordt beredeneerd hoe het handelen wordt aangepast.

'(...) ik vat samen wat de ouders ervoor hebben gezegd, door middel van de vraag: "En volgens mij denken jullie daar hetzelfde over?" Op het moment dat ouders zeggen dat ze afgaan op onze mening, maak ik de ouders duidelijk dat hun mening er ook toe doet.'

2. Perspectief school. Britta betrekt het perspectief van de school in de voorbereiding. Ze refereert aan het beleidsdoel van de school ('De school wil graag laagdrempelig zijn en niet uitstralen van "wij weten het toch beter". Uitgangspunt is: onderwijs maak je samen, ook met ouders.'). Niet duidelijk is wat de formele bron is van dit beleidsdoel, wel duidelijk is dat Britt haar handelen aan dit beleidsdoel aanpast. Uit de nadruk die op dit aspect wordt gelegd blijkt dat Britt graag wil bijdragen aan het beleidsdoel en zich bewust is van het organisatieperspectief.

\section{Conclusie}

Britta laat zien dat zij een aantal concepten in hoofdlijnen, maar niet foutloos, beheerst: ze hanteert concepten adequaat in voorbereiding en analyse, maar ze gebruikt weinig subconcepten en is niet altijd precies in het onderscheid tussen concepten.

Sterk is dat het handelen hoofdzakelijk wordt beredeneerd in de verantwoording (niveau 2 en 3). Minder sterk is dat inhoudelijk de nadruk wordt gelegd op een beperkt aantal aspecten van de gesprekssituatie. De gelijkwaardige relatie met de ouder en het respect voor de ouder, komen herhaaldelijk aan de orde, waardoor de inhoudelijke focus van de verantwoording eenzijdig op dit aspect komt te liggen. Binnen deze inhoudelijke beperking blijkt Britta uitstekend in staat situatiespecifieke informatie en concepten te verbinden in redeneringen over het handelen (niveau 3).

Britta toont empathie voor het perspectief van de ouders. Zij heeft een gelijkwaardige relatie met de ouders als uitgangspunt voor het gesprek, past haar handelen hierop aan en stuurt richting gelijkwaardigheid. Deze gelijkwaardigheid is ook onderdeel van het schoolperspectief. 
In Britta's geval wordt het beoogde niveau van cognitieve flexibiliteit bereikt: zij verantwoordt haar handelen met behulp van concepten en situatiespecifieke informatie op niveau 2 en 3 en past haar handelen aan de situatie aan. Perspectiefwisseling vindt ook plaats: Britta toont een respectvolle en coöperatieve houding tegenover de ouders. Het perspectief van de school wordt betrokken door in algemene zin te refereren aan een beleidsdoel en daarnaar te handelen.

Twee kanttekeningen worden bij dit niveau van cognitieve flexibiliteit geplaatst. Beperkingen liggen in a) het niet foutloze gebruik van concepten, en b) een eenzijdige inhoudelijke focus op de relatie met de ouders, waardoor de communicatieve situatie niet ten volle wordt uitgediept.

\section{Duiding van geval 8: Dobbie Voorbereiding}

Dobbie beschrijft in voorbereiding 1 het communicatieve doel en de referentiële boodschap van het gesprek juist en consistent. Het derde opdrachtgestuurde concept, gespreksopbouw, wordt onjuist uitgewerkt. Dit lijkt te worden veroorzaakt doordat zij de gewoonte van de basisschool om een bepaald gespreksformulier te hanteren, overneemt.

'De opbouw van het gesprek is samengesteld vanuit de punten uit het gespreksformulier van de Pravoo, dat gebruikt wordt op mijn stageschool. Ik heb het format van dit formulier geplaatst in de bijlage.'

Dit formulier bevat echter geen gespreksopbouw, maar een beschrijving van de gespreksinhoud, waardoor begripsverwarring ontstaat. Blijkbaar heeft Dobbie dit verschil niet opgemerkt. Het beschrijven van concepten op niveau 1 laat hiermee een hiaat zien.

Dobbie beschrijft veel situatiespecifieke informatie die relevant is voor een goed begrip van de gesprekssituatie (niveau 1). Ze beschrijft haar wijze van gespreksvoorbereiding, de positieve samenwerking met haar mentor en de gewoonte van de school om een gespreksformulier te gebruiken. Bovendien geeft ze een algemene typering van de school en de stagegroep en beschrijft ze kort de werkwijze van de school met betrekking tot het kennismakingsgesprek:

'Op mijn stageschool wordt er nadat het kind ongeveer een maand onderwijs op de school heeft gehad, een kennismakingsgesprek gevoerd met de ouders. Deze gesprekken hebben als hoofddoel: het welzijn van het kind op de school. Voor de 3 ingestroomde leerlingen moest dit gesprek dus rond februari gevoerd worden. Ik heb ervoor gekozen om één van deze kennismakingsgesprekken uit te werken voor deze portfolio-opdracht.'

In voorbereiding 2 betrekt Dobbie concepten (expressieve boodschap, open houding) in een redenering over haar handelen (niveau 2). Ze beredeneert welke expressieve boodschap ze wil overbrengen en hoe ze die vormgeeft. Minder sterk in deze redenering is dat ze haar handelen niet concreet beschrijft:

'Expressieve boodschap: Ik vind het belangrijk dat ouders hun ervaringen en punten die ze graag willen delen met mij, aan mij kunnen vertellen. Daarom wil ik ervoor zorgen dat ik een open en begripvolle houding uitstraal naar de ouders toe.' 
Het concept relationele boodschap wordt weliswaar concreet beschreven (niveau 1), maar is onjuist geïnterpreteerd. Verder geeft Dobbie relevante situatiespecifieke informatie over de relatie van de ouders met de school, de ruimtelijke opstelling en de aanwezigheid van de mentor. Ook breidt ze de informatie over de werkwijze van de school met betrekking tot het kennismakingsgesprek uit (niveau 1). Aan de situatiespecifieke informatie verbindt Dobbie geen conclusies voor haar handelen.

\section{Analyse}

In analyse 1 beschrijft Dobbie het gespreksfragment en redeneert zij met behulp van diverse concepten (communicatief doel, informeren, luisterende en begripvolle houding; gespreksvaardigheden, luisteren, stellen van vragen, oogcontact) over haar eigen handelen (niveau 2). Ze grijpt daarbij terug op haar voorbereiding: de diverse elementen zijn goed overgekomen. Ze betrekt in haar redenering het positieve effect van haar gespreksvaardigheden op de ouders. Dobbie laat zien dat ze concepten zinvol in haar analyse weet te integreren.

In analyse 2 betrekt Dobbie concepten en situatiespecifieke informatie over de ouders in haar redenering (niveau 3). Zij beredeneert eerst waarom de inbreng van ouders en leerkrachten beide van belang zijn in dit gesprek:

'Het doel van het gesprek was het welbevinden van B. na één maand onderwijs. De ouders en mijn mentor en ik hebben hierbij dezelfde belangen, namelijk dat het goed gaat met B., dat hij het naar zijn zin heeft, etc. Daarbij handelen wij wel vanuit verschillende betrokkenheid en deskundigheid. Om te zorgen voor een goede 'samenwerking' en aanvulling op elkaar moeten we informatie van elkaar winnen/aan elkaar overbrengen.'

Vervolgens licht ze haar handelen toe (inleven in de ouder, vragen voorbereiden en stellen om informatie in te winnen) en analyseert ze het gespreksverloop onder verwijzing naar een kenmerk van de ouders. Dat deel van de analyse ziet er als volgt uit:

'Enerzijds ben ik tevreden en vind ik dat dit goed verlopen is (al waren dit geen ouders waarbij stiltes of iets dergelijks vielen, wat natuurlijk ook een positieve bijdrage was), maar anderzijds liep ik nu tegen het feit aan dat ik veel gesloten vragen heb gesteld. Vaak konden ouders maar één of twee antwoorden geven en moest ik overstappen naar een volgende vraag. De mate van informatie die ik ontvangen heb tijdens dit gesprek is groot genoeg omdat het erg 'kletsende' en open ouders zijn, maar wanneer dit niet het geval was geweest had ik onvoldoende informatie kunnen krijgen naar aanleiding van mijn vragen.'

Ten slotte formuleert Dobbie een handelingsalternatief. De volgende concepten worden geïntegreerd in analyse 2: communicatief doel, betrokkenheid, deskundigheid, informatie inwinnen, gesloten vragen stellen, divergente vragen stellen, doorvragen. Dobbie toont in analyse 2 aan dat ze in staat is situatiespecifieke informatie en concepten te combineren in een analyse van een gespreksfragment (niveau 3). 


\section{Perspectieven}

1. Perspectief ouder. In de voorbereiding geeft Dobbie blijk van aandacht voor het perspectief van de ouder. Dit blijkt bijvoorbeeld uit de formulering van haar expressieve boodschap:

Expressieve boodschap: Ik vind het belangrijk dat ouders hun ervaringen en punten die ze graag willen delen met mij, aan mij kunnen vertellen. Daarom wil ik ervoor zorgen dat ik een open en begripvolle houding uitstraal naar de ouders toe.'

Daarnaast geeft zij de volgende situatiespecifieke informatie over de ouder:

'B. heeft een oudere broer. Hij zit in groep 3 op de school. De ouders zijn hierdoor al bekend met de school en grotendeels met de manier van werken in de onderbouw.'

Dobbie formuleert niet expliciet welk gevolg de bekendheid van de ouders met de werkwijze van de school heeft voor haar eigen handelen.

In de analyse komt het perspectief en het belang van de ouder herhaaldelijk en expliciet naar voren. Dobbie beschrijft de belangen van de ouder en de leerkrachten en benoemt expliciet hoe zij zich heeft verplaatst in het perspectief van de ouders en haar handelen heeft afgestemd:

'De ouders en mijn mentor en ik hebben hierbij dezelfde belangen, namelijk dat het goed gaat met B., dat hij het naar zijn zin heeft, etc. Daarbij handelen wij wel vanuit verschillende betrokkenheid en deskundigheid.'

'Ik wilde in dit fragment graag informatie vanuit de ouders van B. winnen over zijn welbevinden op school. Ik heb voorafgaand aan het gesprek goed nagedacht over wat $i k$ graag wilde weten van de ouders, wat de ouders zouden kunnen gaan vertellen, etc. Kortom: ik heb geprobeerd om mezelf te verplaatsen in de ouders van B. Aan de hand daarvan heb ik enkele vragen voorbereid en gesteld aan de ouders van B. Hierbij heb ik natuurlijk ook mijn eigen aandachtspunt meegenomen, namelijk; vragen paraat hebben. Ik heb dus geprobeerd om hier vooraf zo goed mogelijk voor te zorgen.'

'Het kwam ook op mij over dat deze informatie ook voor ouders duidelijk was. Daarnaast heb ik een luisterende en begripvolle houding naar ouders laten zien toen zij op mijn informatie konden reageren.'

2. Perspectief school. Het perspectief van de school wordt in de voorbereiding ingenomen - beschreven wordt de plaats van het kennismakingsgesprek in het contact tussen ouders en school én de functie van dit gesprek voor ouders en leerkrachten. Er is geen bronvermelding of directe verwijzing naar het schoolbeleid.

'Er heeft alleen een 'aanmeldingsgesprek' tussen ouders en de directie van de school plaatsgevonden voor het inschrijven van B. Verder zijn er aan het gesprek dat ik ga voeren geen gesprekken vooraf gegaan. De leerkrachten van de school voeren 'kennismakingsgesprekken' met ouders van de kinderen nadat de kinderen een maand onderwijs hebben gehad in de desbetreffende groep. Dit doen zij om zo onder andere kennis te maken met elkaar, belangrijke gegevens/aspecten helder te krijgen en het welzijn van het kind en de manier van werken in de groep in beeld te krijgen. Met belangrijke gegevens kunnen de leerkrachten vervolgens gedurende het schooljaar rekening houden, aan werken, etc.'

\section{Conclusie}

De beheersing van de conceptuele structuur door Dobbie laat een gedifferentieerd beeld zien. Enerzijds worden twee opdrachtgestuurde concepten onjuist 
geïnterpreteerd, anderzijds wijst het ruime en juiste gebruik van spontaan gehanteerde concepten in de analyse op een goede beheersing van concepten. Kortom, Dobbie blijkt in staat concepten goed maar niet foutloos te integreren in haar verantwoording.

Situatiespecifieke informatie wordt uitgebreid beschreven in de voorbereiding, waarmee Dobbie aantoont aan oog te hebben voor relevante factoren die de gesprekssituatie beïnvloeden (niveau 1). In de analyse blijkt Dobbie situatiespecifieke informatie én concepten samenhangend te koppelen aan redeneringen over haar handelen (niveau 3).

De voorbereiding en analyse verschillen in kwaliteit: in de voorbereiding worden concepten en situatiespecifieke informatie voornamelijk beschreven (niveau 1), in de analyse wordt met beide geredeneerd (niveau 2 en 3).

Het perspectief van de ouder wordt in de verantwoording herhaaldelijk betrokken. Dobbie benadert de ouders als gelijkwaardige gesprekspartners, is doordrongen van het gezamenlijke belang van leerkracht en ouder en past haar handelen hierop aan. Het perspectief van de school wordt ook betrokken door de gang van zaken in de school te beschrijven.

Het beoogde niveau van cognitieve flexibiliteit wordt bereikt in Dobbie's geval. Zij redeneert voornamelijk op niveau 2 en soms op niveau 3 en er vindt perspectiefwisseling plaats. Zowel het perspectief van de ouders als van de school wordt betrokken in de verantwoording. De getoonde cognitieve flexibiliteit kent echter ook beperkingen: het conceptgebruik is niet foutloos en situatiespecifieke informatie wordt in beperkte mate betrokken in redeneringen.

\section{Duiding van geval 9: Linda Voorbereiding}

In voorbereiding 1 worden de opdrachtgestuurde concepten juist en consistent beschreven, maar inhoudelijk summier uitgewerkt (niveau 1). In voorbereiding 2 verbindt Linda concepten en situatiespecifieke informatie in diverse redeneringen over het handelen (niveau 3) en betrekt ze ook spontaan een concept. De expressieve boodschap wordt geformuleerd (loyaal en professioneel overkomen, begrip tonen) en beschreven wordt hoe deze boodschap vorm krijgt in het handelen:

'De ouders willen graag duidelijke informatie die klopt. Aan de hand van het rapport ga ik de ouders dan ook vertellen hoe het met de ontwikkeling van hun dochter gaat. Zo kan ik alles stap voor stap benoemen en hoef ik niet bang te zijn dat ik iets oversla. Ook heb ik een aantal werkjes bij de hand, zodat ik die aan de ouders kan laten zien. (...).

Mijn begeleidster vertelt de ouders altijd precies hoe het gaat, en draait er niet omheen. Zij zegt: "alleen als jij duidelijk bent, kunnen ouders dat ook zijn".'

Het verband tussen de boodschap en de vormgeving is niet helemaal duidelijk; het gaat vooral om een concretisering van het 'professioneel overkomen', de aspecten loyaliteit en begrip tonen worden niet uitgewerkt. Als argument voor het geven van 
'duidelijke informatie' wordt situatiespecifieke informatie aangedragen, namelijk de opvatting van de mentor.

Linda beschrijft ook hoe de relationele boodschap vorm krijgt in het handelen ('Ik spreek de ouders met "je" aan'). Zij beargumenteert het tutoyeren met situatiespecifieke informatie: tutoyeren is de gewoonte op deze school bij informele gesprekken; de ouders doen dit zelf ook en ze nemen zelf ook initiatief tot het voeren van informele gesprekken met haar. Niet beschreven wordt de feitelijke relationele boodschap: welke relationele boodschap wil Linda met dit handelen overdragen?

In een laatste voorbeeld van redeneren op niveau 3 beschrijft Linda een beleidsdoel en voegt eraan toe hoe zij dat aan beleidsdoel tot nu toe heeft gewerkt.

'Een communicatief beleidsdoel bij ons op school is dat er goede contacten worden onderhouden door de leerkrachten met de ouders/verzorgers van een kind. Zo verkrijg je veel informatie die je nodig hebt om het kind goed te begeleiden in zijn/haar ontwikkeling. Met de ouders heb ik meerdere malen een informeel gesprek gehad, de ouders zien mij als leerkracht van hun kind.'

Met deze redeneringen laat Linda zien dat ze in staat is haar handelen te verantwoorden met concepten en situatiespecifieke informatie op niveau 3, hoewel de redeneringen en concepten niet altijd optimaal zijn uitgewerkt.

Ten slotte betrekt Linda nog situatiespecifieke informatie in een redenering over de ruimtelijke opstelling tijdens het gesprek (niveau 2) en beschrijft zij situatiespecifieke informatie over de ouders (niveau 1).

\section{Analyse}

Linda betrekt vijf concepten (expressieve boodschap, relationele boodschap, referentiële boodschap, ingaan op, effectiviteit) bij de beschrijving en beoordeling van het gespreksfragment in analyse 1 (niveau 2). Ze beschrijft dat ze minder gespannen is en daardoor enerzijds beter in staat is om de juiste woorden te vinden en op de ouder te reageren en anderzijds de ouder meer het woord te geven. Dit komt haar expressieve en relationele boodschap ten goede:

'In het tweede deel van het filmpje merk ik dat het beter gaat. Ik kan beter verwoorden wat $i k$ wil zeggen. En de spanning is weg, hierdoor praat ik makkelijker. Ook ga ik beter in op wat de ouders zegt/ vraagt. Het is tijdens een gesprek wel belangrijk om ook goed op de ouders te reageren. En eigen inbreng te stimuleren, dit verbetert de relatie met de ouders. De expressieve boodschap verandert, ik kan me professioneler opstellen naar de ouders toe. En het gesprek beter leiden. Het verwoorden van dat wat ik wil zeggen gaat beter. (...) Wanneer de expressieve en relationele boodschap beter worden, merk ik dat ik beter in staat ben om naar de referentiële boodschap toe te werken. Ouders komen voor de informatie over de ontwikkeling van hun dochter. En willen evt. antwoord op onduidelijkheden of vragen.'

In analyse 2 beschrijft Linda met behulp van concepten (appellerend doel, referentiële boodschap, expressieve boodschap) uiteenlopende aspecten van de gespreksvoering die ze niet goed vond. Deze aspecten worden kort beschreven en soms beredeneerd (niveau 2). Inhoudelijk worden de verschillende aspecten beperkt behandeld en uitgediept. De tekst bevat een mengeling van beschrijvingen in 
alledaagse taal en beschrijvingen/redeneringen met concepten. Ter illustratie van een beschrijving in alledaagse taal:

'Ik merk dat ik moeite heb met het vinden van de goede woorden, ik stotter soms zelfs. Ook zeg ik heel vaak "uuuh". En ga ik heel precies het rapport af. Er is weinig tot geen vrije inbreng.'

Linda redeneert echter ook met behulp van concepten. Twee voorbeelden hiervan:

'Ik was behoorlijk zenuwachtig in het begin van het gesprek, hierdoor kwam de expressieve boodschap niet zo goed over. Dit kwam ook omdat het opgenomen moest worden. Hierdoor reageer ik niet zo goed op wat de moeder vertelt. Dit had ik beter kunnen doen.'

'Ik vond het lastig om naar het appellerend doel van het gesprek toe te werken. Je hebt de neiging om te zeggen het gaat goed, maar ouders willen ook graag weten waarom het dan goed gaat.'

In de gehele analyse betrekt Lindy concepten zinvol in redeneringen over haar handelen (niveau 2). Inhoudelijk ligt het accent op het communicatieve doel en de expressieve, relationele en referentiële boodschap.

\section{Perspectieven}

1. Perspectief ouder. Het perspectief van de ouder wordt betrokken in de voorbereiding. Hierin wordt met name het belang van duidelijke informatie benadrukt. Dit blijkt uit diverse formuleringen:

'De ouders willen graag duidelijke informatie die klopt.'

'Het is belangrijk om duidelijk te zijn naar de ouders toe. Zij weten dan ook waar ze aan toe zijn.'

In de analyse heeft Linda herhaaldelijk oog voor de ouder. Ze benoemt opnieuw het 'informatie-aspect', maar ook het belang van een goede relatie met de ouder. Twee voorbeelden die dit illustreren:

'De ouders krijgen in het begin van het gesprek niet zoveel kans om wat te vertellen. Dit vind ik wel heel belangrijk, want de ouders weten het meest over het kind. Zij zijn de experts.'

'Het is tijdens een gesprek wel belangrijk om ook goed op de ouders te reageren. En eigen inbreng te stimuleren, dit verbetert de relatie met de ouders.'

2. Perspectief school. Het perspectief van de school wordt genoemd in de voorbereiding door te verwijzen naar een algemeen geformuleerd beleidsdoel. De bron hiervan is niet duidelijk en wordt niet genoemd. Linda beschrijft wel hoe zij heeft bijgedragen aan dit beleidsdoel.

'Een communicatief beleidsdoel bij ons op school is dat er goede contacten worden onderhouden door de leerkrachten met de ouders/verzorgers van een kind. Zo verkrijg je veel informatie die je nodig hebt om het kind goed te begeleiden in zijn/haar ontwikkeling. Met de ouders heb ik meerdere malen een informeel gesprek gehad, de ouders zien mij als leerkracht van hun kind.'

Ook benoemt Linda het belang van kijkavonden (visitekaartje). Niet uitgewerkt wordt wat dit betekent voor het handelen van de leerkracht

'Ik vind kijkavonden een visite kaartje van de school. De ouders kunnen in de klas kijken waar hun kind zit en de sfeer proeven. Verder krijgen ze informatie over de ontwikkeling van hun kind.' 
In beide citaten geeft Linda blijk van een zeker besef van het organisatiebelang en van een zekere medeverantwoordelijkheid daarvoor, hoewel dit besef niet expliciet wordt beredeneerd.

\section{Conclusie}

De verantwoording van Linda kent als geheel veel sterke elementen en enkele zwakkere. Linda geeft blijk van beheersing van de concepten: ze beschrijft de opdrachtgestuurde concepten consistent; verder hanteert ze in de analyse (in ruime mate) en in de voorbereiding (in beperkte mate) spontaan concepten.

Sterk is dat Linda in de voorbereiding situatiespecifieke informatie en concepten diverse keren in redeneringen over haar handelen betrekt (niveau 3), waarmee ze gevoel voor de situatie toont en haar handelen daarop blijkt af te stemmen. In de analyse worden concepten zinvol betrokken in redeneringen over het handelen (niveau 2). Minder sterk is dat in de gehele verantwoording de concepten en de redeneringen inhoudelijk niet optimaal worden uitgewerkt.

Het perspectief van de ouder wordt herhaaldelijk betrokken in de verantwoording (vooral de behoefte van ouders aan duidelijke informatie); het perspectief van de school wordt betrokken (zonder verwijzing naar formele bronnen) en ook wordt globaal beschreven hoe hieraan uitvoering is gegeven.

Kortom, het beoogde niveau van cognitieve flexibiliteit wordt in Linda's geval bereikt. $\mathrm{Zij}$ redeneert samenhangend met concepten en situatiespecifieke informatie over haar handelen (niveau 3) en ze redeneert met concepten (niveau 2). Perspectiefwisseling vindt ook plaats: het perspectief van de ouder wordt herhaaldelijk betrokken en geconcretiseerd in het handelen en het perspectief van de school wordt ingenomen.

Bij beide aspecten van de beoogde cognitieve flexibiliteit wordt een kanttekening geplaatst. Een kanttekening betreft de inhoudelijke diepgang waarmee concepten worden ingevuld en redeneringen worden uitgewerkt. Deze kent enige beperking. De tweede kanttekening betreft de perspectiefwisseling: het ouderperspectief is inhoudelijk beperkt tot de behoefte aan duidelijke informatie en het schoolperspectief is globaal geformuleerd. Sterk hieraan is weer wel dat beschreven is hoe de student in haar handelen aan het schoolbeleid heeft bijgedragen.

\subsubsection{Vergelijking van voldoende gevallen}

Tussen de zes voldoende gevallen worden overeenkomsten gesignaleerd, maar de diversiteit binnen de gevallen is groot en de patronen zijn soms minder helder afgetekend.

Conceptuele structuur wordt grotendeels beheerst en spontaan toegepast.

De voldoende gevallen hanteren de opdrachtgestuurde concepten hoofdzakelijk juist en zij gebruiken allemaal concepten ook spontaan. De conceptuele structuur wordt echter niet optimaal beheerst. Elk geval, op Veerle na, kent ook een zwakke kant aan 
het conceptgebruik: soms worden de concepten niet precies onderscheiden, soms worden weinig subconcepten gebruikt of worden weinig concepten spontaan gehanteerd.

\section{Relevante situatiespecifieke informatie wordt geselecteerd.}

In de voldoende gevallen wordt relevante situatiespecifieke informatie geselecteerd die van invloed is op de gesprekssituatie. De studenten laten hiermee zien dat ze een goed begrip van de communicatieve situatie hebben en de factoren die daarin een rol spelen. Per geval heeft de informatie steeds betrekking op diverse aspecten van de communicatieve situatie, maar de mate waarin situatiespecifieke informatie wordt geselecteerd verschilt wel: Dobbie valt op door een grote hoeveelheid diverse informatie, terwijl in het geval van Britta de focus sterk op één bepaalde factor ligt. De overige gevallen bevinden zich daartussenin.

Verantwoording bevat redeneringen van niveau 2 en 3; handelen wordt afgestemd op situatie. Variatie bestaat in de balans tussen redeneren met (niveau 2/3) en beschrijven van situatiespecifieke informatie (niveau 1) en in de kwaliteit van het beschreven handelen.

In de wijze waarop concepten en situatiespecifieke informatie in de verantwoording wordt betrokken, tekent zich het volgende af. In alle voldoende gevallen komen redeneringen van niveau 2 voor, dat wil zeggen dat ofwel een concept ofwel situatiespecifieke informatie wordt gebruikt in een redenering over het handelen. De mate waarin niveau 3 voorkomt verschilt onderling: bij Britta en Linda gebeurt dit herhaaldelijk, in de andere gevallen is het incidenteel.

In alle gevallen wordt ook situatiespecifieke informatie beschreven zonder dat er conclusies voor het handelen aan worden verbonden (niveau 1) - de mate waarin niveau 1 zich voordoet, verschilt onderling ook. In de drie gevallen van Veerle, Britta, Linda gebeurt dit beperkt en in de drie gevallen van Desi, Lara, Dobbie gebeurt dit herhaaldelijk. Weliswaar is de beschreven situatiespecifieke informatie altijd relevant voor een goed begrip van de situatie, maar de laatste groep weet niet altijd te expliciteren welke invloed de informatie heeft op het eigen handelen. Geconcludeerd kan worden dat de balans tussen redeneren met en beschrijven van situatiespecifieke informatie verschillend is tussen deze groepen.

De studenten blijken allen in staat hun handelen op de situatie af te stemmen. Variatie is zichtbaar in de wijze waarop dit handelen wordt geformuleerd: van concreet tot globaal. Deze variatie bestaat tussen de verschillende gevallen, maar ook binnen de gevallen. Bij Lara, Veerle en Linda wordt het handelen overwegend concreet beschreven, bij Desi, Britta en Dobbie verschilt dit op onderdelen van de verantwoording.

Perspectiefwisseling vindt plaats. Innemen ouderperspectief vindt plaats en krijgt (vrijwel altijd) concrete uitwerking op handelingsniveau; Innemen schoolperspectief vindt in vijf gevallen plaats, de uitwerking ervan varieert.

De voldoende gevallen laten allemaal perspectiefwisseling zien. Het ouderperspectief wordt door alle gevallen betrokken in de verantwoording, waarbij het belang van de 
ouder en van een gelijkwaardige en respectvolle verhouding wordt geformuleerd. Verder weten de studenten concreet te beschrijven hoe het ouderperspectief hun handelen beïnvloedt, hoewel dit in één geval (Desi) beperkt gebeurt.

De diepgang waarmee het ouderperspectief wordt ingenomen, varieert. Twee uitersten op dit gebied vormen Veerle en Desi. Een professionele attitude laat Veerle zien. $\mathrm{Zij}$ is zich bewust van een mogelijk inhoudelijk conflict met de ouder, maar verenigt in deze situatie professionele distantie en een respectvolle houding tegenover de ouders. Desi benoemt het ouderperspectief wel, maar heeft hier minder ruimte voor; zij blijft dicht bij haar eigen beleving van de situatie.

Het perspectief van de school waarmee organisatiebewustzijn wordt getoond, wordt door alle voldoende gevallen, op een na (Desi), ingenomen. Dit gebeurt op twee manieren: Britta en Linda refereren in globale zin aan het beleid van de school beschrijven kort hoe zij in hun handelen aan dat beleid bijdragen. Lara, Veerle en Dobbie beschrijven concreet de gang van zaken op hun school - de mogelijke relatie met hun eigen handelen wordt niet geëxpliciteerd. In geen enkel geval wordt verwezen naar of geciteerd uit een formele bron.

Ten slotte, in de voldoende gevallen zijn enkele overeenkomsten gesignaleerd die op hoofdlijnen aangeven wat typerend is voor de getoonde cognitieve flexibiliteit. Tegelijkertijd laat de vergelijking zien dat elk geval een unieke combinatie vormt van sterke en zwakke elementen, hoewel het beoogde niveau van cognitieve flexibiliteit in alle gevallen wordt bereikt.

Op basis van de kwaliteit van onderzochte elementen (concepten, situatiespecifieke informatie, wijze van betrekken van concepten en situatiespecifieke informatie, perspectiefwisseling) wordt het spectrum van de voldoende gevallen als volgt ingedeeld:

- Veel sterke elementen: Veerle, Britta

- Sterke en zwakke elementen gemengd: Lara, Dobbie, Linda

- Veel zwakke elementen: Desi

\subsection{Conclusie}

In deze studie is onderzocht hoe de cognitieve flexibiliteit van studenten die zich in een authentieke situatie bevinden, zich manifesteert. Het onderzoek heeft zich gericht op drie vragen. Ten eerste is onderzocht hoe studenten concepten en situatiespecifieke informatie verbinden in de schriftelijke verantwoording van hun handelen in een authentieke situatie en ten tweede is onderzocht in hoeverre de perspectieven van ouder en school in die verantwoording worden betrokken. Ten derde is nagegaan in hoeverre het beoogde niveau van cognitieve flexibiliteit is bereikt.

Uit een vergelijking van goede en voldoende gevallen rijst een beeld op van het spectrum waarbinnen de bereikte cognitieve flexibiliteit zich bevindt. Dit beeld is niet simpelweg te vatten in twee karakteriseringen, maar kent met name voor de voldoende gevallen nuances en kanttekeningen. In deze conclusie zullen 
onderzoeksvraag 1 en 2 eerst apart worden beantwoord en vervolgens met elkaar in verband worden gebracht om te komen tot conclusies over de getoonde cognitieve flexibiliteit.

\section{Hoe verbinden studenten concepten en situatiespecifieke informatie in de schriftelijke verantwoording van hun handelen in een authentieke situatie?}

Gebleken is dat alle studenten in staat zijn situatiespecifieke informatie en concepten samenhangend te hanteren in een redenering over hun handelen (niveau 3). Dit houdt in dat situatiespecifieke informatie wordt herkend als factor in de communicatie, dat deze wordt gerelateerd aan een concept en dat het handelen wordt afgestemd op de situatie. Enerzijds krijgen concepten hierdoor een op de situatie toegesneden inkleuring en anderzijds wordt de situatiespecifieke informatie geïnterpreteerd binnen een conceptueel kader; deze wisselwerking leidt tot een betekenisvolle onderbouwing van het handelen.

Ook is gebleken dat alle studenten hun handelen verantwoorden in redeneringen waarbij concepten of relevante situatiespecifieke informatie worden betrokken (niveau 2). Dit resulteert in onderbouwingen van het handelen die of een analytisch karakter hebben of waaruit oog voor de situatie spreekt. Gebleken is tevens dat alle studenten spontaan concepten hanteren.

Ten slotte bevatten alle verantwoordingen ook beschrijvingen van situatiespecifieke informatie die relevant zijn voor een goed begrip van de communicatieve situatie (niveau 1).

Naast deze gemeenschappelijke kenmerken van de manier waarop concepten en situatiespecifieke factoren door de studenten worden gehanteerd, laten de goede en voldoende gevallen ook drie kwalitatieve verschillen zien.

Ten eerste is in het omgaan met situatiespecifieke informatie bij de voldoende gevallen een tweedeling zichtbaar: de helft van de gevallen bevat relatief veel beschrijvingen van situatiespecifieke factoren (niveau 1). Dit duidt erop dat deze studenten wel oog hebben voor situatiespecifieke factoren, maar dat ze niet steeds in staat zijn het verband met hun eigen handelen op te merken. Gebleken is dat bij de goede gevallen situatiespecifieke factoren vrijwel steeds in redeneringen over het handelen worden betrokken (niveau 2 of 3 ).

Een tweede verschil is opgemerkt in de kwaliteit waarmee de conceptuele structuur wordt beheerst. Bij de voldoende gevallen is de beheersing van de concepten gevarieerder en niet in alle opzichten optimaal. De wijze waarop dit zich manifesteert is per geval verschillend. Enerzijds worden opdrachtgestuurde concepten hoofdzakelijk juist gehanteerd en worden concepten spontaan gehanteerd. Anderzijds worden soms fouten gemaakt, weinig subconcepten gebruikt of weinig concepten spontaan gehanteerd. De goede gevallen tonen een diepgaande beheersing van de conceptuele structuur door middel van een juiste interpretatie van concepten, het gebruik van subconcepten en het spontaan gebruik van concepten.

En een derde verschil ligt in de kwaliteit waarmee het professioneel handelen wordt beschreven. Bij de voldoende gevallen doet de helft dit concreet en kent de andere helft 
hierin veel variatie, van een globale aanduiding tot een concrete handeling. Bij de goede gevallen wordt het professioneel handelen nauwkeurig en concreet beschreven.

\section{In hoeverre betrekken studenten de perspectieven van ouder en school bij de schriftelijke} verantwoording van hun handelen in een authentieke situatie?

In alle gevallen wordt het ouderperspectief betrokken in de afwegingen over het handelen. Studenten hebben oog voor de ouders in de communicatie, beseffen het belang van een goede relatie tussen ouders en leerkracht en tonen een waarderende en respectvolle attitude. Zij blijken (op één na) deze professionele attitude ook te concretiseren op handelingsniveau.

Het schoolperspectief wordt in vrijwel alle gevallen (7) betrokken in de verantwoording. Studenten refereren aan het schoolbeleid en/of beschrijven de gang van zaken met betrekking tot communicatie met ouders binnen de school. De studenten tonen hiermee organisatiebewustzijn als beginnend professional; zij beschouwen niet sec een gesprek met ouders, maar expliciteren het bredere kader waarbinnen communicatie met ouders plaatsvindt. Drie gevallen plaatsen bovendien het eigen handelen in het licht van het schoolbeleid, waarmee concreet wordt aangegeven hoe wordt bijgedragen aan de doelstelling van de organisatie.

Wat betreft het innemen van perspectieven zijn ook enkele kwalitatieve verschillen opgemerkt.

Ten eerste is gebleken dat de kwaliteit waarmee het ouderperspectief wordt betrokken in de goede gevallen hoog is. Het ouderperspectief wordt consequent betrokken, rekening wordt gehouden met diverse aspecten (emoties, belangen, relatie) en het handelingsniveau wordt concreet uitgewerkt. Bij de voldoende gevallen bestaat meer variatie in de kwaliteit, van vergelijkbaar met de goede gevallen tot duidelijk zwakker in alle aspecten (één geval).

Ten tweede is gebleken dat er een verschil is in de wijze waarop het schoolperspectief wordt betrokken door de goede en voldoende gevallen. Twee goede gevallen benoemen het schoolperspectief op een hoger abstractieniveau door te verwijzen naar formele bronnen voor schoolbeleid en vijf voldoende gevallen beschrijven op concreet niveau de gang van zaken in de basisschool.

Verder is opgevallen dat één goed geval (Chery) en één voldoende geval (Desi) het schoolperspectief geheel niet benoemen. Bij Desi past dit in het algehele zwakke beeld van de verantwoording, bij Chery is het opmerkelijk vanwege de algehele diepgang die wordt getoond.

\section{Beoogde cognitieve flexibiliteit}

Geconcludeerd wordt ten eerste dat alle studenten de beoogde cognitieve flexibiliteit in onderwijsarrangement 4 bereiken. Dit blijkt uit het beredeneren van het professioneel handelen in de communicatieve situatie met concepten en/of situatiespecifieke informatie (niveau 2 en 3). Tevens blijken alle studenten in staat tot perspectiefwisseling. Het ouderperspectief wordt altijd ingenomen en krijgt een 
concrete uitwerking op handelingsniveau; het schoolperspectief wordt in zeven van de negen gevallen ingenomen en krijgt in drie gevallen uitwerking op handelingsniveau.

Geconcludeerd wordt ten tweede dat de kwaliteit van de bereikte cognitieve flexibiliteit varieert. De duiding en vergelijking van goede en voldoende gevallen heeft laten zien dat de kwaliteit van de bereikte cognitieve flexibiliteit afhankelijk is van de combinatie van een aantal aspecten. De goede gevallen vertonen een consistent patroon van hoge kwaliteit op alle aspecten (met een enkel foutje) en de voldoende gevallen vertonen een gevarieerder patroon met sterke en zwakke kanten.

Voor de voldoende gevallen liggen er enkele kansen om tot optimalisering te komen van de cognitieve flexibiliteit:

- Concepten inhoudelijk verdiepen;

- Situatiespecifieke informatie meer betrekken in redeneringen over het handelen (van niveau 1 naar niveau 2).

Voor alle gevallen geldt dat het innemen van het schoolperspectief getuigt van het organisatiebewustzijn van een beginnend professional. De reikwijdte en diepte hiervan kunnen worden uitgebreid in een volgende fase van de ontwikkeling als professional (de inductiefase) wanneer met het toenemen van ervaring, meer ruimte ontstaat voor het denken over en bijdragen aan de bredere context van de schoolorganisatie.

\subsection{Onderzoeksmethode studie 2}

\section{Onderzoeksvraag}

Het ontwerp heeft als nevendoelstelling een professioneel discours onder studenten te bevorderen. Kenmerkend voor een professioneel discours is het hanteren van vaktaal. In dat kader wordt in deze studie onderzocht in hoeverre studenten concepten hanteren in een mondelinge samenvatting van een reflectief gesprek over hun professionele communicatieve vaardigheden. De essentie van de taak ligt in het abstraheren van concrete situaties en ervaringen met behulp van concepten. De onderzoeksvraag luidt: In hoeverre integreren studenten concepten in een mondelinge samenvatting van een reflectief gesprek over hun communicatie met ouders?

Nagegaan wordt in hoeverre studenten in een dergelijke samenvatting gebruik maken van concepten. De mondelinge taak wordt uitgevoerd in een informele setting en met beperkte voorbereidingstijd. Het actief gebruik van concepten in een dergelijke setting wordt beschouwd als een indicatie voor de ontwikkeling van een professioneel discours.

De taak vergt niet alleen het gebruik van concepten - wat op zichzelf al een vorm van abstraheren is - maar doet ook een beroep op het vermogen om te abstraheren van concrete situaties en uitspraken te doen met een algemeen karakter. Daarom wordt ook nagegaan of in de samenvattingen geabstraheerd wordt van concrete situaties met behulp van concepten. 


\section{Participanten}

In deze studie is gebruik gemaakt van dezelfde studentenpopulatie als in studie 1. De data zijn verzameld tijdens de tweede bijeenkomst van het onderwijsarrangement. Het maximaal mogelijke aantal deelnemende studenten aan deze bijeenkomst was 152. Aanwezig waren 93 studenten (61\%) en onder hen zijn de data verzameld. Afwezigheid van studenten wordt verklaard door stageverplichtingen, buitenlandstages en roostertechnische problemen. De studenten doen een groepsopdracht in drietallen en daarom is er sprake van 31 gevallen.

\section{Dataverzameling en procedure}

Tijdens de tweede bijeenkomst van onderwijsarrangement 4 zijn video-opnamen verzameld van een groepsopdracht. Studenten hebben in drietallen zelf videoopnamen gemaakt van de samenvatting van hun reflectieve gesprek over communicatie met ouders. Er zijn 31 video-opnamen verzameld waarvan er 30 bruikbaar zijn. Deze worden betrokken in het onderzoek. De video-opnamen variëren in lengte van ruim één minuut tot bijna vijf minuten (tussen 01:08 en 04:45 $\mathrm{min})$. De gemiddelde duur is ruim twee minuten (02:18 $\mathrm{min})$.

Voorafgaand aan de video-opname hebben studenten tijdens de bijeenkomst in drietallen hun ervaringen met het voeren van een gesprek met ouders in de basisschool uitgewisseld. Zij hebben elkaar daarbij delen van hun eigen videoopname getoond, hun keuzes en dilemma's besproken en gereflecteerd op sterke en zwakke kanten van hun professioneel handelen. Na deze uitgebreide reflectie hebben zij de opdracht gekregen een mondelinge samenvatting te geven van het zojuist gevoerde collegiale en reflectieve gesprek. Expliciet wordt hen gevraagd in de samenvatting eerder geleerde concepten uit de conceptuele structuur te verwerken. De selectie van concepten in de mondelinge samenvatting wordt door de studenten zelf bepaald. De taak vergt van de studenten een zekere mate van abstractie, het loskomen van de concrete situaties en ervaringen waarover zij met elkaar hebben gesproken, en biedt daardoor de mogelijkheid concepten te gebruiken. De samenvatting is kort voorbereid door de groep en vervolgens door henzelf op video opgenomen. In de samenvatting beschrijven de studenten:

- de belangrijkste gespreksonderwerpen

- de belangrijkste leeropbrengst van de uitgevoerde opdracht in de basisschool

- sterke en zwakke kanten van hun communicatieve vaardigheden.

De opdracht voor studenten is te vinden in Bijlage G. De opdracht is verschillend uitgevoerd. Zo worden de gespreksonderwerpen niet in alle gevallen genoemd en wordt de leeropbrengst soms per persoon geformuleerd en soms per groep. De essentie van de taak, het abstraheren van concrete situaties en ervaringen met behulp van concepten, wordt hierdoor echter niet aangetast.

\section{Instrument}

Voor het inventariseren van de concepten is gebruik gemaakt van een lijst met een opsomming van alle basisconcepten uit de conceptuele structuur, inclusief een aantal 
bijbehorende subconcepten (Bijlage A). Een deel van deze lijst is eerder gebruikt in hoofdstuk 6 voor het inventariseren van concepten. De verzameling subconcepten in het instrument is niet uitputtend; bij bepaalde basisconcepten hoort een uitgebreide set van subconcepten die in de vakliteratuur wordt genoemd.

\section{Dataverwerking}

Van alle video-opnamen is een protocol uitgeschreven. Elke protocol is opgedeeld in drie onderdelen:

1. gespreksonderwerpen

2. leeropbrengst

3. sterke en zwakke kanten.

Een protocol is ter illustratie opgenomen in Bijlage $\mathrm{H}$.

\section{Data-analyse}

Om na te gaan in hoeverre studenten concepten integreren in de mondelinge samenvatting is de gehele dataset geanalyseerd op het gebruik van concepten. Per geval is geïnventariseerd hoeveel verschillende concepten zijn gehanteerd en welke het zijn. Als concepten herhaaldelijk worden genoemd in de samenvatting, zijn ze eenmaal geteld. Na de inventarisatie van de concepten, is gezocht naar patronen in de soort concepten die zijn gebruikt, bijvoorbeeld of de concepten een bepaalde overeenkomst of inhoudelijke samenhang vertonen.

De inventarisatie van de concepten heeft plaatsgevonden door de onderzoeker en een inhoudsdeskundige. Beide hebben alle protocollen doorgenomen en concepten gemarkeerd. De uitkomsten zijn vergeleken en bij verschillende uitkomsten is gediscussieerd en tot consensus gekomen. Over zes concepten is gediscussieerd; dit betrof voornamelijk enkele gespreksvaardigheden.

Vervolgens is per geval nagegaan of studenten in hun formulering weten te abstraheren van één concrete communicatieve situatie met behulp van concepten. Dit houdt in dat zij uitspraken met behulp van concepten doen die een generiek karakter hebben, dat wil zeggen dat de uitspraak betrokken is op oudergesprekken in het algemeen. Dit in tegenstelling tot uitspraken met een specifiek karakter die betrokken zijn op één situatie. Nagegaan is of de samenvatting minimaal één uitspraak met concepten bevat die een generiek karakter heeft. In Tabel 7.4 is een voorbeeld gegeven van een generieke uitspraak.

Tabel 7.4 Voorbeeld van generieke uitspraak

Generieke uitspraak

Onze belangrijkste leeropbrengst is dat het gesprek in duidelijke fasen verloopt - en dat je altijd rekening moet houden met wat je expressieve boodschap en je relationele boodschap is. En belangrijk is dat je voor jezelf duidelijk hebt wat je communicatieve boodschap is, wat je communicatieve doel is.

De leeropbrengst is geformuleerd met behulp van enkele concepten (expressieve boodschap, relationele boodschap, communicatief doel). Met deze concepten wordt geabstraheerd van één specifieke gesprekssituatie en wordt een generieke uitspraak gedaan over gespreksvoering. 


\subsection{Resultaten}

\section{Aantal concepten}

Het aantal verschillende concepten dat wordt geïntegreerd in de mondelinge samenvatting van het reflectieve gesprek geeft een eerste indicatie van het conceptgebruik. Uit de analyse van de samenvattingen blijkt dat in alle gevallen concepten worden geïntegreerd. Gemiddeld worden zes concepten per samenvatting gehanteerd. Er is wel een grote spreiding zichtbaar, met een minimum van twee en een maximum van zestien concepten.

\section{Soort concepten en patroon in conceptgebruik}

Een nadere analyse van het soort concepten dat is geïntegreerd in de samenvatting geeft een inhoudelijk beeld van het conceptgebruik. Er tekent zich een driedeling af in de soort gehanteerde concepten:

- concepten behorend bij gespreksvaardigheden

- concepten behorend bij het communicatiemodel

- overige concepten.

Opgevallen is dat in alle gevallen (op één uitzondering na) concepten uit de categorie gespreksvaardigheden worden betrokken. Uit het integreren van gespreksvaardigheden door alle gevallen blijkt vertrouwdheid met deze concepten. Het benoemen van de vaardigheden die bij communicatie horen, lijkt voor de studenten het meest vanzelfsprekend. Het benoemen van gespreksvaardigheden hangt waarschijnlijk ook samen met de aard van de opdracht. Met name het onderdeel waarin gevraagd wordt sterke en zwakke kanten van de communicatieve vaardigheden te beschrijven, geeft aanleiding tot het benoemen van gespreksvaardigheden.

Daarnaast is opgevallen dat in tweeëntwintig gevallen behalve gespreksvaardigheden ook andere categorieën concepten worden geïntegreerd in de samenvatting. In zeven gevallen worden uitsluitend gespreksvaardigheden geïntegreerd en in één uitzonderingsgeval uitsluitend concepten uit het communicatiemodel. Tabel 7.5 geeft een overzicht van de verschillende categorieën concepten die zijn geïntegreerd in de samenvattingen.

Tabel 7.5 Verdeling van categorieën concepten

\begin{tabular}{l|c|c|c|c|c|c} 
Aantal gevallen/ & 7 & 6 & 6 & 10 & 1 & $=30$ totaal \\
Categorie concepten & & & & & & \\
Gespreksvaardigheden & $\mathrm{x}$ & $\mathrm{x}$ & $\mathrm{x}$ & $\mathrm{x}$ & & \\
Communicatiemodel & & $\mathrm{x}$ & & $\mathrm{x}$ & $\mathrm{x}$ & \\
Overig & & & $\mathrm{x}$ & $\mathrm{x}$ & &
\end{tabular}


Ruim de helft van de gevallen (17) blijkt concepten uit het communicatiemodel te integreren in de samenvatting. Deze concepten zijn in principe op iedere situatie toepasbaar, maar ze zijn analytisch van aard en vergen per definitie een analytische blik op communicatieve situaties. Dat ruim de helft van de gevallen dergelijke concepten integreert in de mondelinge samenvatting, wijst erop dat zij zich vertrouwd hebben gemaakt met een analytische blik op communicatie.

Verder blijkt ook ruim de helft van de gevallen (16), naast gespreksvaardigheden, overige concepten te verwerken in de samenvatting. Deze categorie beslaat een ongelijksoortige verzameling van concepten die niet allemaal op iedere situatie van toepassing zijn. Opgemerkt is dat in deze categorie een concept dat wel algemeen toepasbaar is (gespreksopbouw) relatief vaak wordt geïntegreerd, maar ook concepten die meer situatiespecifiek zijn (interculturele gesprekken, dynamische driehoek) worden incidenteel genoemd.

\section{Mate van abstractie}

In zevenentwintig gevallen worden in de samenvatting generieke uitspraken over communicatie met behulp van concepten; in de formulering wordt geabstraheerd van een specifieke gesprekssituatie of ervaring met gebruikmaking van concepten. In drie gevallen blijven de studenten in hun formuleringen dichtbij één gesprekssituatie en de concrete ervaring daarin of hanteren zij geen concepten. Alle onderdelen van de mondelinge taak geven aanleiding tot het abstraheren van concrete gesprekssituaties en ervaringen. De meeste groepen studenten blijken hiertoe in staat.

\subsection{Conclusie en discussie}

In deze studie is nagegaan in hoeverre studenten concepten integreren in een gezamenlijke mondelinge samenvatting van een professioneel gesprek over communicatie met ouders. Ook is onderzocht of in de samenvattingen met behulp van concepten wordt geabstraheerd van concrete situaties en of uitspraken worden gedaan met een generiek karakter. In deze paragraaf worden conclusies geformuleerd en wordt bediscussieerd wat de betekenis is van de resultaten in relatie tot de ontwikkeling van een professioneel discours en cognitieve flexibiliteit.

\section{Conclusie}

De studie levert de volgende conclusies op.

1. Alle groepen studenten integreren concepten in de mondelinge samenvatting.

Alle groepen studenten blijken in staat, met weinig voorbereidingstijd en in een informele setting, concepten te integreren in een mondelinge taak. Het conceptgebruik in een dergelijke natuurlijke situatie geeft een aanwijzing voor de verankering van concepten in het taalgebruik van studenten en duidt op de ontwikkeling van een professioneel discours. 
Typerend in het conceptgebruik is dat alle gevallen (minus één) concepten met betrekking tot gespreksvaardigheden benoemen. Driekwart van de groepen studenten benoemt daarnaast ook concepten die behoren tot het communicatiemodel en/ of overige concepten.

2. De meeste groepen studenten (27) abstraheren van concrete situaties en ervaringen met concepten.

Cognitieve flexibiliteit heeft als doel transfer van concepten naar verschillende situaties te bewerkstelligen. In dit kader is het voorwaardelijk over conceptuele kennis te beschikken en over het vermogen om enerzijds het specifieke van situaties te beschrijven met concepten en anderzijds het algemene van situaties te herkennen; cognitieve flexibiliteit betekent dat er steeds wordt 'gependeld' tussen concrete situatie en abstract concept. De gegeven taak, een mondelinge samenvatting geven van een gesprek met behulp van concepten, doet een beroep op beide elementen en geeft daardoor een indicatie van de ontwikkeling van cognitieve flexibiliteit. De meeste groepen studenten blijken in staat te zijn generieke uitspraken over communicatie te doen met behulp van concepten. Het feit dat studenten in staat zijn te abstraheren van concrete situaties en daarbij concepten integreren, is dan ook een positieve indicatie voor de ontwikkeling van cognitieve flexibiliteit.

\section{Discussie}

De studie heeft laten zien dat studenten een professioneel discours beginnen te ontwikkelen door het integreren van concepten in hun taalgebruik. De resultaten ondersteunen ook de ontwikkeling van cognitieve flexibiliteit doordat het merendeel van de studenten in staat blijkt te abstraheren van concrete situaties en generieke uitspraken te doen. Deze conclusies moeten wel worden geplaatst in het licht van de gehanteerde methode die enkele beperkingen kent.

Een kwestie betreft de waarde die gehecht kan worden aan het conceptgebruik in de mondelinge samenvattingen. De samenvattingen zijn verschillend van inhoud, aangezien in de samengevatte gesprekken unieke praktijkervaringen zijn gedeeld. Toevallige gespreksonderwerpen geven aanleiding voor het gebruiken van bepaalde concepten of juist tot het niet gebruiken ervan in de samenvatting van dit gesprek. Hierdoor is het conceptgebruik in de samenvattingen onderling moeilijk vergelijkbaar en kan op basis van het conceptgebruik geen uitspraak worden gedaan over de beheersing van de conceptuele structuur. Ook is er sprake van een groepsopdracht waardoor niet duidelijk is wat de individuele inbreng van iedere student is en welke invloed de groepsdynamiek heeft op de uitvoering van de taak. Dit maakt dat het niet mogelijk is uitspraken te doen over individuele studenten.

Wel geeft het conceptgebruik in een informele, natuurlijke situatie een indicatie van de mate waarin concepten tot het vanzelfsprekende taalgebruik van de studenten behoren en daadwerkelijk betekenis voor hen hebben. Het feit dat alle studenten concepten hanteren en dat driekwart verschillende soorten concepten hanteert, duidt op vertrouwdheid met concepten en is een positieve indicatie voor de ontwikkeling van een professioneel discours. 


\section{HOOFDSTUK 8}

\section{Reflectie}

Dit laatste hoofdstuk bevat een terugblik op het onderzoek. In paragraaf 8.1 wordt eerst een recapitulatie gegeven van het onderzoek. Vervolgens wordt gereflecteerd op diverse aspecten van het onderzoek: op de betekenis van de cognitieve flexibiliteitstheorie voor het onderzoek wordt ingegaan in paragraaf 8.2 en daarna worden achtereenvolgens de bevindingen van de formatieve evaluatie en de effectmeting bediscussieerd in paragraaf 8.3 en 8.4. In paragraaf 8.5 komt aan de orde wat het onderzoek heeft bijgedragen aan de cognitieve flexibiliteitstheorie. Met aanbevelingen voor vervolgonderzoek en de praktijk van de lerarenopleiding wordt in paragraaf 8.6 afgesloten.

\subsection{Recapitulatie van het onderzoek}

In deze paragraaf wordt de grote lijn van het onderzoek beknopt weergegeven. Achtereenvolgens worden de achtergrond (8.1.1) en context van het onderzoek (8.1.2) kort geschetst. Daarna worden het doel en de opzet van het onderzoek in hoofdlijnen beschreven (8.1.3) en ten slotte de opbrengsten van het onderzoek (8.1.4).

\subsubsection{Achtergrond}

Een belangrijke doelstelling binnen lerarenopleidingen is dat studenten in staat zijn om hun professioneel handelen in de beroepspraktijk met behulp van een theoretisch begrippenkader te beredeneren en te sturen. De vertaalslag van theorie naar praktijksituaties blijkt echter een weerbarstig proces en studenten, lerarenopleiders en leraren ervaren een discrepantie tussen de theoretische inzichten die in de lerarenopleiding aangereikt worden en de benodigde vaardigheden voor de beroepspraktijk. Dit onderzoek heeft zich gericht op de problematische relatie tussen theorie en praktijk in de lerarenopleiding, met als algemene onderzoeksvraag: Hoe kan een betekenisvolle verbinding worden bewerkstelligd tussen conceptuele kennis en professioneel handelen?

Als theoretisch kader is hiervoor de cognitive flexibility theory (CFT) gehanteerd (Jacobson \& Spiro, 1995; Jones \& Spiro, 1992; Spiro, Collins, \& Ramchandran, 2007; Spiro, Collins, Thota, \& Feltovich, 2003; Spiro \& DeSchryver, 2009; Spiro, Feltovich, Jacobson, \& Coulson, 1992). De cognitieve flexibiliteitstheorie erkent expliciet de complexiteit van het verwerven en toepassen van concepten (theorie) op uiteenlopende, complexe praktijksituaties. Zij gaat uit van een leerproces op basis van cases (case-based learning) als veelbelovendste voorbereiding op het handelen in complexe praktijksituaties. De theorie geeft vanuit een ken- en leertheoretisch 
perspectief inzicht in het samenspel van factoren dat maakt dat de toepassing van conceptuele kennis problematisch is in bepaalde (ill-structured) domeinen zoals het onderwijs. Bovendien geeft zij vanuit een instructietechnologisch perspectief richtlijnen voor de vormgeving van een leeromgeving (met videocases als centraal element) waarmee complexe leerdoelen worden nagestreefd.

Nieuw in dit onderzoek is dat de CFT is toegepast in de context van een beroepsopleiding. De empirische basis van de CFT ligt voornamelijk in de (Amerikaanse) academische context (Choi \& Lee, 2009; Derry, Hmelo-Silver, Nagarajan, Chernobilsky, \& Beitzel, 2006; Derry \& STEP Team, 2003; Eilam \& Poyas, 2006). De verbinding van een conceptuele structuur aan professioneel handelen in een beroepsopleiding stelt specifieke eisen aan de leeromgeving. In het onderzoek is dan ook gepoogd de uitgangspunten van de CFT te operationaliseren voor een beroepsopleidingscontext en de waarde van de CFT voor deze context te beproeven.

\subsubsection{Ontwerpen voor een concrete context}

In een lerarenopleiding voor primair onderwijs manifesteerde zich ook een concreet en specifiek probleem. Deze lerarenopleiding had, vanwege de invoering van een nieuw curriculum dat inhoudelijk is gestoeld op de competenties van het lerarenberoep (zoals beschreven in de Wet op de beroepen in het onderwijs, 2006), behoefte aan de ontwikkeling van competentiegericht onderwijs over communicatie met ouders. Dat het van belang is aanstaande leraren op deze beroepstaak goed voor te bereiden blijkt uit het feit dat communicatie met ouders door beginnende leraren als problematisch wordt ervaren (Gaikhorst, 2014). Het ontwerpprobleem waarop het onderzoek zich heeft gericht, werd: Hoe kan een betekenisvolle verbinding worden bewerkstelligd tussen conceptuele kennis en professioneel handelen in het domein 'communiceren met ouders'?

Het ontwerpen van een interventie voor deze specifieke context bracht twee issues met zich mee die kenmerkend zijn voor het ontwerp- en onderzoeksproces. Ten eerste diende de interventie om bruikbaar te zijn, te voldoen aan de randvoorwaarde van een beperkt aantal studiepunten; de uitdaging was dan ook een realistische oplossing te vinden voor het theorie-praktijkvraagstuk.

Ten tweede diende de interventie competentiegericht te zijn en geïmplementeerd te worden in een organisatie die zich in een vernieuwingsproces bevond. Deze situatie had gevolgen voor het implementatieproces van de interventie. Ten tijde van de ontwikkeling van de interventie stond de lerarenopleiding aan het begin van de overgang van een modulair naar een competentiegericht curriculum. Het idee van een curriculum dat is opgebouwd rondom authentieke beroepstaken, behoorde nog niet tot het gedachtengoed en de uitvoeringspraktijk van de opleiding. In deze dynamische overgangssituatie werd de interventie meteen tijdens het ontwerp- en onderzoeksproces geïmplementeerd in het reguliere curriculum van de opleiding. Dit betekende niet alleen dat er in een vroeg stadium hoge eisen werden gesteld aan de praktische bruikbaarheid van de interventie, maar ook dat veel energie moest worden geïnvesteerd in de professionalisering van docenten en in contacten met het beroepsveld. Daarnaast is veel aandacht uitgegaan naar de praktische kant van de 
implementatie zoals het creëren van een infrastructuur ter ondersteuning van de implementatie van de interventie (onder andere ict-faciliteiten, verankering in onderwijs- en toetsplannen et cetera). De vertrouwdheid van de onderzoeker met de organisatie is dit complexe implementatieproces ten goede gekomen.

Een duurzame implementatie ten slotte vraagt niet alleen institutionalisering, maar ook blijvende aandacht voor het onderhoud van de interventie. Daarin zijn twee punten van wezenlijk belang voor de kwaliteit van het onderwijs: de continue professionalisering van docenten (vanwege instroom van nieuwe of tijdelijke docenten) en de bewaking van de samenhang van de vier onderwijsarrangementen binnen de interventie. In een omgeving waarin, onder invloed van nieuwe ontwikkelingen en praktische overwegingen, voortdurend herziening van het curriculum plaatsvindt, is dit geen vanzelfsprekendheid.

\subsubsection{Doel en opzet van het onderzoek}

Dit onderzoek had twee doelstellingen. De eerste doelstelling betrof het ontwerpen en evalueren van een interventie, die een leerproces bewerkstelligt waarin conceptuele kennis en professioneel handelen betekenisvol met elkaar worden verbonden. De 'verbinding van conceptuele kennis en professioneel handelen' is beschouwd met behulp van de cognitieve flexibiliteitstheorie en geconcretiseerd in termen van cognitieve flexibiliteit. Het doel van de interventie was om een leerproces te bevorderen dat bijdraagt aan de ontwikkeling van cognitieve flexibiliteit. Met het onderzoek is beoogd inzicht te verkrijgen in dit leerproces en de wijze waarop de cognitieve flexibiliteit van aanstaande leraren (studenten) zich manifesteert.

Met de interventie werd ook een subdoel nagestreefd, namelijk het bevorderen van een professioneel discours van aanstaande leraren. Kenmerkend voor een professioneel discours is het gebruik van vaktaal/concepten in de onderlinge communicatie van vakgenoten over praktijksituaties. De subdoelstelling hangt samen met het hoofddoel van de interventie, aangezien het gebruik van concepten ook een wezenlijk aspect is van cognitieve flexibiliteit.

De tweede doelstelling van het onderzoek betrof theorievorming. Beoogd werd een bijdrage te leveren aan de cognitieve flexibiliteitstheorie door te beproeven hoe deze theorie kan worden toegepast in de context van een lerarenopleiding.

\section{Opzet van het onderzoek}

Het onderzoek is opgezet als een ontwerponderzoek. In de eerste fase van het onderzoek is op systematische wijze een interventie ontwikkeld. Op basis van een literatuuronderzoek (naar de cognitieve flexibiliteitstheorie en case based-learning) en een behoefteanalyse werden ontwerprichtlijnen geformuleerd. Vervolgens is een meerdelig curriculum- en instructieontwerp voor het domein 'communiceren met ouders' in de lerarenopleiding ontwikkeld. Het ontwerp bestond in deze fase aanvankelijk uit drie opeenvolgende onderwijsarrangementen (voor eerste tot en met derdejaars studenten) die toenemen in complexiteit.

In de tweede fase van het onderzoek heeft de formatieve evaluatie van de interventie plaatsgevonden. Deze studies hebben plaatsgevonden in een reële onderwijssetting, 
aangezien de onderwijsarrangementen werden geïmplementeerd in het reguliere opleidingsprogramma van een lerarenopleiding. De evaluatie van de praktische bruikbaarheid heeft geleid tot de toevoeging van een vierde onderwijsarrangement aan de interventie (voor vierdejaars studenten) en tot concrete verbeteringen op uitvoeringsniveau. De evaluatie van de potentiële effectiviteit heeft een eerste indicatie van de leerresultaten opgeleverd, inzicht in het leerproces van studenten bij de ontwikkeling van cognitieve flexibiliteit, gericht op het hanteren van een conceptuele structuur, en een aanscherping van het gedachtengoed over het leren van concepten.

In de derde fase van het onderzoek heeft de effectmeting van de interventie plaatsgevonden, die is uitgevoerd in twee verschillende onderdelen van de interventie. De eerste effectevaluatie vond na het tweede onderwijsarrangement plaats en heeft in een vroeg stadium van de interventie inzicht gegeven in de mate waarin en de kwaliteit waarmee cognitieve flexibiliteit zich manifesteert bij studenten in semi-authentieke situaties. De evaluatie van de leerresultaten had hier betrekking op twee aspecten van cognitieve flexibiliteit, namelijk het hanteren van een conceptuele structuur en het innemen van diverse perspectieven.

De tweede effectevaluatie vond na het vierde onderwijsarrangement plaats en heeft in het eindstadium van de interventie inzicht gegeven in de kwaliteit waarmee cognitieve flexibiliteit van studenten zich manifesteert in de volle complexiteit van authentieke situaties, met inbegrip van de drie aspecten van cognitieve flexibiliteit, namelijk het hanteren van een conceptuele structuur, het innemen van diverse perspectieven en het betrekken van situatiespecifieke informatie. Parallel aan het onderzoeken van de cognitieve flexibiliteit is in beide studies nagegaan in hoeverre studenten een professioneel discours ontwikkelen.

\subsubsection{Opbrengsten van het onderzoek}

Dit onderzoek heeft verschillende opbrengsten opgeleverd die hier in hoofdlijnen worden genoemd.

1. Een vierdelig curriculum- en instructieontwerp dat praktisch bruikbaar is en geimplementeerd is in het reguliere opleidingsprogramma van een lerarenopleiding.

Het curriculum- en instructieontwerp is praktisch bruikbaar gebleken voor studenten en docenten. Het bestaat uit vier opeenvolgende, in complexiteit toenemende onderwijsarrangementen die een steeds hoger niveau van denken en professioneel handelen van de student vragen op het gebied van 'communicatie met ouders'. De onderwijsarrangementen zijn gericht op eerste tot en met vierdejaars studenten van de lerarenopleiding. Een centraal element in het ontwerp is het gebruik van videocases en een conceptuele structuur.

Dat docenten en studenten de praktische bruikbaarheid positief waardeerden was van groot belang, aangezien van hen een afwijkende werkwijze werd gevergd, waarin de geïntegreerde didactische aanpak van het bestuderen en produceren van (digitale) videocases nieuw was. Gebruik maken van digitale (video)technologie was op dat moment in de lerarenopleiding ongebruikelijk. Ook de opbouw van de interventie rondom authentieke beroepstaken en met een beperkte, terugkerende conceptuele structuur was nieuw en vergde een aanpassing in het denken van docenten. 
2. Inzicht in de manifestatie van cognitieve flexibiliteit en het bijbehorende leerproces.

Een beoogd doel van de interventie was het ontwikkelen van cognitieve flexibiliteit door studenten. Gebleken is dat studenten aan het eind van de interventie het nagestreefde niveau van cognitieve flexibiliteit bereiken.

Het onderzoek heeft ook een concreet en genuanceerd beeld opgeleverd van de wijze waarop die cognitieve flexibiliteit zich manifesteert in het domein 'communicatie met ouders'. Het laat zien dat de kwaliteit van de getoonde cognitieve flexibiliteit gevarieerd is en hoe de kwaliteit wordt bepaald door de combinatie van een aantal aspecten. De goede gevallen vertonen een consistent patroon van hoge kwaliteit op alle aspecten en de voldoende gevallen vertonen een gevarieerder patroon met sterke en zwakke kanten.

3. Een positieve indicatie voor de ontwikkeling van een professioneel discours.

Een subdoelstelling van de interventie was het bevorderen van een professioneel discours onder studenten. Uit het onderzoek is gebleken dat studenten in staat zijn concepten te integreren in hun mondelinge taalgebruik in open leertaken. De eerste effectevaluatie wees uit dat studenten concepten integreren in een mondelinge reflectie op hun handelen en bij de tweede effectevaluatie bleek dat studenten concepten integreren in een reflectief gesprek. Vooral het conceptgebruik in een natuurlijke en informele situatie (laatste onderwijsarrangement) geeft een overtuigende aanwijzing voor de verankering van concepten in het taalgebruik van studenten en duidt op de ontwikkeling van een professioneel discours.

4. Inzicht in de toepassingsmogelijkheden van de CFT voor beroepsopleidingscontext.

De CFT is een goede basis gebleken voor drie verschillende aspecten van het onderzoek: het doorgronden van het theorie-praktijkvraagstuk in de probleemanalyse, het ontwerpen van de interventie en het begrijpen van het leerproces en de leerresultaten van studenten. Tegelijkertijd waren de ontwerprichtlijnen niet toereikend en specifiek genoeg om een volledig curriculumen instructieontwerp met een opbouw in complexiteit op te baseren. Ook was het een vraagstuk hoe de relatie met het professioneel handelen in de beroepspraktijk gelegd kon worden. Oplossingen voor deze kwesties hebben geleid tot aanvullingen op de ontwerprichtlijnen.

\subsection{Reflectie op de toepassing van de cognitieve flexibiliteitstheorie}

In dit onderzoek hebben inzichten uit de cognitieve flexibiliteitstheorie als theoretische basis gediend. In deze paragraaf wordt de waarde van de cognitieve flexibiliteitstheorie voor het ontwerp- en onderzoeksproces bediscussieerd. In welke opzichten hebben de ideeën van de CFT bijgedragen aan het onderzoek? En vice versa, wat heeft het onderzoek opgeleverd aan inzichten over de CFT als theoretische 
basis? Drie aspecten komen aan de orde: de probleemanalyse (8.2.1), het curriculumen instructieontwerp (8.2.2) en de leerresultaten (8.2.3).

\subsubsection{Probleemanalyse}

De CFT als perspectief heeft geleid tot een dieper inzicht in de complexiteit van het theorie-praktijkvraagstuk, in het bijzonder in de complexiteit van het verwerven van een conceptuele structuur en de toepassing ervan op uiteenlopende praktijksituaties. Waarom is het gebruik van concepten door studenten zo'n hardnekkig probleem? Waaruit bestaat die complexiteit nu precies? Deze vragen werden met behulp van de CFT uitgelicht en vanuit een ken- en leertheoretisch perspectief benaderd (zie hiervoor hoofdstuk 2).

De cognitieve flexibiliteitstheorie richt zich op het leren van de gevorderde student en streeft naar het bereiken van complexe leerdoelen in ill-structured domeinen. Een algemene doelstelling is het verwerven van transferabele kennis om complexe (en illstructured) praktijksituaties of problemen op te lossen op een wijze die gelijkenis vertoont met de aanpak van experts, waarbij het toepassen van concepten uit diverse domeinen en de sensitiviteit voor de specifieke context kenmerkend zijn voor de nagestreefde cognitieve flexibiliteit. Typerend voor een ill-structured domein is dat iedere situatie daarin uniek is en dat per situatie diverse factoren moeten worden afgewogen om tot adequaat handelen te komen. In dergelijke domeinen volstaat het niet om via de toepassing van vaste procedures en welomschreven concepten tot een zinvolle oplossing van een probleem te komen. Communicatie met ouders is zo'n illstructured domein waarin iedere situatie op zijn merites moet worden beoordeeld om tot een zinvolle oplossing of adequaat handelen te komen.

De variabele verschijningsvorm van concepten, de manier waarop concepten onderling samenhangen in een specifieke context, de onvergelijkbaarheid van cases én de noodzaak tot het combineren van concepten uit verschillende kennisdomeinen zijn factoren die gezamenlijk de complexiteit van situaties in een ill-structured domein bepalen.

Ons onderzoek heeft met behulp van de CFT geïllustreerd waarom het analyseren en interpreteren van praktijksituaties met behulp van concepten (theorie) in het domein communicatie met ouders ingewikkeld is en geen rechtlijnige benadering toestaat. Vanuit dit perspectief is het begrijpelijk dat het gebruik van concepten veel aandacht en een gerichte instructie behoeft. Dit inzicht in de complexe interactieve relatie tussen theorie en praktijk heeft binnen het onderzoek geleid tot een focus op het gebruik van conceptuele kennis door studenten.

\subsubsection{Curriculum- en instructieontwerp}

De ontwerprichtlijnen, afgeleid van de cognitieve flexibiliteitstheorie, zijn richtinggevend geweest voor de vormgeving van het curriculum- en instructieontwerp. Vanwege het algemene karakter van de richtlijnen was een vertaalslag nodig om ze te concretiseren voor een specifiek domein en een specifieke context met bepaalde randvoorwaarden. Het curriculum- en instructieontwerp, beschreven in hoofdstuk 3, waarmee conceptuele kennis en professioneel handelen 
met behulp van videocases in het domein 'communicatie met ouders' worden verbonden, is vormgegeven op basis van de volgende vier ontwerprichtlijnen:

1. Gebruik maken van realistische situaties (Derry \& STEP Team, 2003; Kolodner, 1996; Spiro et al., 1992)

2. Centrale concepten van een domein bestuderen in diverse contexten (Derry \& STEP Team, 2003; Kolodner, 2006; Spiro et al., 1992)

3. Cases interpreteren met behulp van concepten uit verscheidene domeinen (Derry \& STEP Team, 2003; Siegel et al., 2000; Spiro et al., 1992)

4. Diepgaand bestuderen van een beperkt aantal rijke videocases (Derry et al., 2006; Spiro et al., 2007).

De ontwerprichtlijnen bleken echter niet toereikend voor het ontwerp; ze vergden uitbreiding en nuancering. Die toevoegingen kunnen worden beschouwd als aanvullingen op de ontwerprichtlijnen die noodzakelijk zijn om een interventie te ontwerpen die geschikt is voor een beroepsopleiding waarin professioneel handelen centraal staat. De aanvullingen betreffen de relatie met het professioneel handelen in de beroepspraktijk, samenwerkend leren, een in complexiteit toenemend curriculum en het relatieve belang van het gebruik van concepten uit verschillende domeinen in een beroepsopleiding.

\section{Instructieontwerp: relatie met professioneel handelen}

De centrale uitdaging bij het ontwerpen van de interventie was om een betekenisvolle verbinding te leggen tussen conceptuele kennis en professioneel handelen. Deze verbinding is tot stand gebracht in het instructieontwerp door een didactisch model te hanteren waarin het leren met behulp van videocases op een specifieke wijze is uitgewerkt. Het bestuderen én produceren van videocases door de student en het gebruikmaken van een conceptuele structuur zijn daarin centrale elementen. De verbinding van conceptuele kennis en professioneel handelen vindt plaats door het consequent koppelen van twee kerntaken:

1. analyse en interpretatie van een videocasus, met behulp van concepten

2. productie van eigen videobeelden, inclusief toelichting met concepten.

In het instructieontwerp wordt dus structureel plaatsgemaakt voor het produceren van own video naast het bestuderen van published video (Zhang et al., 2010) in combinatie met het gebruik van concepten. Door het produceren van eigen videobeelden komt het professioneel handelen van de student centraal te staan. Op deze wijze is het hanteren van concepten geen theoretische oefening, maar wordt een direct verband gelegd tussen concepten en het eigen professioneel handelen, waarmee de kans op een betekenisvol gebruik van concepten vergroot wordt.

Kortom, voor het ontwerpen van een instructie is ontwerprichtlijn 4 ('Diepgaand bestuderen van een beperkt aantal rijke videocases') aangevuld met een specifiek didactisch model waarin de productie van videobeelden van eigen professioneel handelen van de student van wezenlijk belang is om de relatie met professioneel handelen te bewerkstelligen. Bovendien wordt het gebruik van een conceptuele structuur in alle leeractiviteiten consequent geïntegreerd om het professioneel handelen te verbinden met conceptuele kennis. 


\section{I nstructieontwerp: interactie}

Een tweede toegevoegd element in het instructieontwerp is de kennisconstructie door middel van interactie. Uitgaand van het situated karakter van kennis (zoals de CFT doet), is het van belang dat studenten deelnemen aan een sociale en professionele omgeving waarin die kennis van belang is. Bij het leren van videocases kan dit sociale aspect worden bevorderd door leeractiviteiten of 'social practices' op verschillende niveaus te ontwerpen die uitnodigen tot interactie, uitwisseling en het geven van feedback (Kim \& Hannafin, 2008b). De leeractiviteiten in het gehele instructieontwerp zijn gebaseerd op het uitgangspunt van coöperatief leren en creëren interactie tussen verschillende groepen deelnemers aan de professionele omgeving: (a) studenten onderling, (b) student en lerarenopleider en (c) student en leerkracht basisonderwijs. Deze leeractiviteiten leveren tegelijkertijd contexten op waarin de concepten gehanteerd kunnen worden en dragen op die manier tevens bij aan ontwerprichtlijn 2 .

Voor het ontwerpen van een instructie is ontwerprichtlijn 4 aangevuld met leeractiviteiten die interactie op verschillende niveaus tot stand brengen, waarmee sociale kennisconstructie in betekenisvolle contexten wordt bewerkstelligd.

\section{Curriculumontwerp: opbouw in complexiteit}

Hoewel de CFT richtlijnen geeft voor het vormgeven van een curriculum en leeromgeving, geeft de theorie geen aanwijzingen voor het aanbrengen van een opbouw in het leren van cognitieve flexibiliteit. Een onderscheid wordt weliswaar gemaakt tussen introductory en advanced learning, maar een nadere fasering van het advanced learning waarop de CFT zich richt, vindt niet plaats. In het vierdelige curriculum- en instructieontwerp is een opbouw in complexiteit en in leerdoelen wel aangebracht om eerste- tot en met vierdejaars studenten stapsgewijs te begeleiden naar cognitieve flexibiliteit.

De opbouw in complexiteit betreft verschillende aspecten. Ten eerste nemen de situaties in de videocases toe in complexiteit, dat wil zeggen dat steeds meer kennis van concepten uit diverse domeinen benodigd is en dat het soort gesprek toeneemt in moeilijkheidsgraad; tegelijkertijd neemt de rolnabijheid juist af (van student naar stagiaire naar leerkracht). Ten tweede neemt de complexiteit toe op het terrein van het professioneel handelen. De situatie waarin professioneel handelen getoond wordt, verandert namelijk van semi-authentiek (rollenspel) naar authentiek (beroepspraktijk). Ten derde zijn leerdoelen geformuleerd die een opbouw laten zien in de cognitieve flexibiliteit. Per onderwijsarrangement zijn accenten gelegd in de leerdoelen, op basis van de operationalisering van cognitieve flexibiliteit. In onderwijsarrangement 1 lag het accent op het gebruik van de conceptuele structuur, in onderwijsarrangement 2 en 3 werd het innemen van diverse perspectieven daaraan toegevoegd en in onderwijsarrangement 4 werd het betrekken van situatiespecifieke factoren aan het geheel toegevoegd.

Voor het ontwerpen van een curriculum op basis van de CFT is een opbouw in complexiteit van praktijksituaties, professioneel handelen en leerdoelen voor cognitieve flexibiliteit een noodzakelijke aanvulling. 


\section{Curriculumontwerp: concepten uit verschillende domeinen?}

Uit de evaluatie van het ontwerpproces blijkt dat in de concretisering van ontwerprichtlijn 3 een inhoudelijke aanpassing heeft plaatsgevonden. Ontwerprichtlijn 3 ('Cases interpreteren met behulp van concepten uit verscheidene domeinen') komt voort uit de gedachte dat voor het analyseren van (en handelen in) realistische situaties meestal kennis uit verschillende domeinen gecombineerd moet worden. De cognitieve flexibiliteitstheorie spreekt in dit verband ook van 'verschillende perspectieven' op een probleem. In het ontwerp zijn daarom concepten uit verschillende kennisdomeinen samengebracht in de conceptuele structuur. De conceptuele structuur bevat hoofdzakelijk concepten uit de communicatiekunde, maar daarnaast ook een verzameling uiteenlopende concepten die relevant zijn in de onderwijscontext uit de pedagogiek en ook een begrip uit het juridische domein (wet- en regelgeving omtrent informatievoorziening van basisscholen aan ouders). Deze concepten uit verschillende kennisdomeinen zijn zinvol voor een veelzijdig en genuanceerd begrip van de communicatieve situatie en staan in dienst van het professioneel communicatief handelen. De perspectieven (ofwel kennisdomeinen) fungeren echter niet, zoals in de cognitieve flexibiliteitstheorie, als intellectuele perspectieven op het probleem: in het ontwerp is geen sprake van een pedagogisch of juridisch perspectief op het probleem, met bijbehorende redeneringen, maar eerder van kenniselementen die het communicatieve perspectief verrijken.

Het aspect 'perspectieven innemen' heeft in een andere betekenis wel een plaats gekregen in het ontwerp. Want de operationalisering van cognitieve flexibiliteit voor het domein communicatie met ouders leidde tot het maken van een onderscheid in drie elementen, waarvan 'diverse perspectieven innemen op de communicatieve situatie' er één is. Het afwegen van de belangen en perspectieven van verschillende betrokkenen in een communicatieve situatie is essentieel voor een goed begrip van de communicatieve situatie en voor het bepalen van een adequate handelingsstrategie.

Het aspect 'perspectieven' (ofwel kennisdomeinen) in het ontwerp is dus gemodificeerd. Aan de ene kant blijken de oorspronkelijke perspectieven beperkt te zijn tot kenniselementen ter verrijking van het communicatieve perspectief en ten dienste te staan van het professioneel handelen. Aan de andere kant heeft het 'innemen van diverse perspectieven' nadrukkelijk een plaats gekregen als inhoudelijk onderdeel van cognitieve flexibiliteit in het domein communicatie.

Een verklaring hiervoor ligt in twee kenmerken van het ontwerp. Ten eerste in de context van het ontwerp, een beroepsopleiding. In een beroepsopleiding staat het professioneel handelen centraal: de intellectuele perspectieven die de CFT voorstelt als 'lenzen' op of interpretatiekaders voor een bepaald probleem, zijn minder relevant voor een beroepsopleiding. De conceptuele structuur dient vooral ondersteunend te zijn voor het verantwoorden van professioneel en concreet handelen in realistische situaties en niet voor het handelen als cognitieve activiteit. Ten tweede kan de verschuiving van het aspect 'perspectieven' verklaard worden door de specifieke inhoud van het domein communicatie. De inhoudelijke 
kenmerken van het domein bleken medebepalend te zijn voor de operationalisering van cognitieve flexibiliteit in dat domein.

Uit deze ervaring in het ontwerpproces wordt de volgende aanvulling op ontwerprichtlijn 3 afgeleid. In een beroepsopleidingscontext, kunnen de verscheidene kennisdomeinen die dienen als perspectieven op de situatie beter worden opgevat als kenniselementen die deel uitmaken van de conceptuele structuur, waarbij ze dienen ter verrijking van het dominante perspectief en ter ondersteuning van het professioneel handelen.

\subsubsection{Inzicht in de manifestatie van cognitieve flexibiliteit}

Cognitieve flexibiliteit is in ons onderzoek opgevat als 'beredeneerd professioneel handelen' dat als volgt wordt geoperationaliseerd:

- de onderbouwing van professioneel handelen in realistische situaties met behulp van een conceptuele structuur, waarbij

- verschillende perspectieven en

- specifieke contextfactoren worden betrokken.

Tijdens het onderzoek heeft het inzicht in het karakter van cognitieve flexibiliteit zich ontwikkeld en is steeds duidelijker geworden waaruit de complexiteit bestaat. Door de operationalisering in de drie aspecten werd het mogelijk de interactie van factoren bij de manifestatie van cognitieve flexibiliteit te analyseren.

De eerste toepassing van het concept cognitieve flexibiliteit in een specifieke context leidde gaandeweg tot een preciezere operationalisering van het concept. In de effectevaluaties kon de verschijningsvorm van cognitieve flexibiliteit vervolgens preciezer worden geanalyseerd en werd inzicht in het concept verder verdiept. Dit ontwerpproces laat zien dat de toepassing van theoretische inzichten plaatsvindt in verschillende rondes en dat die rondes nodig zijn voor een werkelijk diep begrip van de theoretische inzichten en van de specifieke toepassingscontext.

Samengevat leidde de toepassing van de cognitieve flexibiliteitstheorie in ons onderzoek tot een verdieping van de probleemanalyse en tot een focus op het gebruik van concepten. Voor het curriculum- en instructieontwerp was de CFT op hoofdlijnen behulpzaam en richtinggevend, maar de ontwerprichtlijnen vergden een vergaande concretisering en uitbreiding. De belangrijkste aanvullingen betroffen:

- een specifiek didactisch model waarin de productie van videobeelden van eigen professioneel handelen van de student centraal staat om de relatie met professioneel handelen te leggen en waarin het gebruik van een conceptuele structuur in alle leeractiviteiten is geïntegreerd;

- structurele interactie tussen verschillende groepen deelnemers aan de professionele omgeving (studenten, lerarenopleiders, leraren) om sociale kennisconstructie te bevorderen in betekenisvolle contexten;

- een opbouw in complexiteit van praktijksituaties, professioneel handelen en cognitieve flexibiliteit;

- een conceptuele structuur van het domein communicatie met relevante concepten uit andere kennisdomeinen die het professioneel handelen ondersteunen. 
De aanvullingen zijn waardevol gebleken voor de kwaliteit van de leerresultaten van studenten; uit het onderzoek komt naar voren dat de studenten in staat zijn tot beredeneerd professioneel handelen.

Voor de analyse en interpretatie van de leerresultaten van studenten was de CFT waardevol, omdat verschillende factoren onderscheiden konden worden die het gebruik van concepten beïnvloeden.

\subsection{Reflectie op de formatieve evaluatie}

De formatieve evaluatiefase in dit onderzoek was gericht op de praktische bruikbaarheid en de potentiële effectiviteit (de leeropbrengsten) van de interventie. In deze paragraaf wordt gereflecteerd op twee aspecten van de formatieve evaluatiestudies: de opbrengsten van de evaluatiestudies (8.3.1) en de rol van de onderzoeker in de formatieve evaluatie (8.3.2).

\subsubsection{Reflectie op opbrengsten}

Het belang van formatieve evaluatie voor een interventie wordt in ontwerponderzoek breed onderkend (van den Akker, 2013; McKenney, Nieveen, \& van den Akker, 2006; McKenney \& Reeves, 2012; Nieveen, 2009; Nieveen \& Folmer, 2013; Plomp, 2013; Tessmer, 1993). In ons onderzoek is de formatieve evaluatiefase van belang gebleken voor de optimalisering van de praktische bruikbaarheid van de interventie en voor de aanscherping van het achterliggende gedachtengoed over het leren en toepassen van concepten.

\section{Praktische bruikbaarheid}

De evaluatie van de praktische bruikbaarheid door docenten en studenten heeft geleid tot gedetailleerde en meer fundamentele verbeteringen voor de uitvoering van de onderwijsarrangementen, zoals in hoofdstuk 4 is beschreven. Die verbeteringen betroffen in onderwijsarrangement 1 en 2 diverse materialen en (toetsings)procedures, waarin vooral de uitbreiding van de digitale concept map van wezenlijk belang was. Uit deze evaluaties kwam ook een element naar voren dat de praktische bruikbaarheid bedreigde. In de onderwijsarrangementen bleek te weinig tijd beschikbaar voor de docent om het verwerven van de conceptuele structuur te ondersteunen (onderwijsarrangement 1) en de toepassing ervan te begeleiden (onderwijsarrangement 2). Docenten wezen op de grote kwaliteitsverschillen in de toepassing van de concepten en een deel van de studenten wees op de noodzaak van meer instructie en begeleiding. Hierin is voor zover mogelijk verbetering gebracht, maar de uitbreiding van de docentbegeleiding kon, binnen de beperkende randvoorwaarden die golden voor de interventie, niet anders dan minimaal zijn.

De evaluatie van onderwijsarrangement 3 heeft, naast gedetailleerde verbeteringen, ook een fundamentele verbetering van de praktische bruikbaarheid van het ontwerp opgeleverd. Zowel docenten als studenten gaven de wens te kennen meer aandacht te willen besteden aan de ontwikkeling van communicatieve vaardigheden. Docenten 
hadden geconstateerd dat de communicatieve vaardigheden onvoldoende vooruitgang toonden en studenten vonden het oefenen in een semi-authentieke context met medestudenten in deze fase te weinig leerzaam en motiverend. In het licht van de bedoeling van het ontwerp - het verbinden van conceptuele kennis en professioneel handelen - is het belangrijk dat conceptuele kennis en communicatieve vaardigheden zich gedurende de interventie in samenhang én evenwichtig ontwikkelen. Daarom is een vierde onderwijsarrangement aan het ontwerp toegevoegd waarin de oefening van de communicatieve vaardigheden meer expliciete aandacht $\mathrm{kreeg}$ in een voor studenten motiverende semi-authentieke context (training met acteur) en een authentieke context (gesprek met ouders in basisschool). De toevoeging van een vierde onderwijsarrangement betekende wel een aanpassing van de randvoorwaarden waarbinnen het ontwerp zich bewoog: ook studiepunten in het vierde jaar van de opleiding werden vrijgemaakt voor het onderwerp communiceren met ouders.

Uit de evaluatie van de praktische bruikbaarheid bleek verder dat docenten de interventie uitvoerden zoals bedoeld. De onderwijsarrangementen bestonden uit concrete, uitgewerkte materialen (digitale leeromgeving met videocases en conceptuele structuur, docentenhandleiding, beoordelingscriteria) en vroegen van de docenten een didactische aanpak die enigszins afwijkend was van hun gebruikelijke praktijk vanwege de consequente aandacht voor de verbinding van concepten en professioneel handelen en de centrale rol van videocases. Docenten waardeerden de didactische aanpak positief zodat er geen problemen werden geconstateerd op het vlak van de congruentie ('congruence', Doyle \& Ponder, 1973-1974). Congruentie heeft betrekking op de mate waarin een vernieuwing aansluit op de gangbare werkwijze en opvattingen van een docent. Daarnaast rapporteerden zij over het opvallende enthousiasme van de studenten voor de interventie. Studenten zelf bleken met name de efficiënte opzet, het produceren van videobeelden en de toetsing in de vorm van presentaties met videobeelden positief te waarderen.

\section{Leeropbrengsten}

De evaluatie van de leerresultaten leverde een positieve indicatie op voor de werking van het onderwijsarrangement: Studenten waren in staat hun communicatief handelen in situaties met ouders te onderbouwen met concepten, hoewel ook kwaliteitsverschillen in het conceptgebruik bleken. Deze resultaten waren in overeenstemming met de evaluatie van de praktische bruikbaarheid waarin docenten ook een grote variatie in het niveau van conceptgebruik hadden opgemerkt. De variatie werd ten dele verklaard door de motivatie van de student voor conceptuele verdieping. Motivatie hiervoor bleek een noodzakelijke voorwaarde te zijn voor het op gang brengen van het beoogde leerproces en de beoogde leerresultaten. De verklaring voor de variatie lag ook ten dele in het voorgaande, inleidende onderwijsarrangement, waarin de basis van de conceptuele structuur verworven diende te worden. Een deel van de studenten beheerste de conceptuele structuur nog onvoldoende om hem al adequaat te kunnen toepassen op complexere situaties in de 
volgende fase. De overgang van introductory learning naar advanced learning (cf. cognitieve flexibiliteitstheorie) bleek voor hen te snel gemaakt te worden.

Dit inzicht in de leerresultaten leidde tot een aanscherping van het gedachtengoed over het leren en toepassen van concepten. Het bleek voor een goede beheersing van de conceptuele structuur van belang ruimschoots aandacht te besteden aan de eerste fase van introductory learning. Daarnaast bleek de toepassing van concepten in de volgende fase van advanced learning voor (een deel van de) studenten ondersteuning op maat te behoeven.

\subsubsection{De kritische rol van de onderzoeker}

In een formatieve evaluatie worden verbeteringen voor een interventie-in-wording gezocht. Daartoe moeten de evaluatieresultaten worden beoordeeld. Wij menen dat de onderzoeker een belangrijke interpretatieve rol heeft in de formatieve evaluatie op basis van zijn deskundigheid van en verantwoordelijkheid voor het ontwerp. De onderzoeker is in deze fase van het ontwerpproces bij uitstek degene die kennis heeft van de bedoeling van het ontwerp en de context waarin dit ontwerp functioneert; kennis die hem in staat stelt de bevindingen op hun waarde te schatten. Daarom is het waardevol dat juist de onderzoeker de verbetersuggesties en de bevindingen van de gebruikers interpreteert en daaraan gevolgtrekkingen verbindt voor het optimaliseren van het ontwerp.

Een terugkerend discussiepunt in ontwerponderzoek is in hoeverre de onderzoeker voldoende distantie heeft van zijn ontwerp om de evaluatieresultaten op zijn merites te kunnen beoordelen. De conflicterende rollen van de onderzoeker, ontwerper en vaak ook implementator, en de mogelijke belangenverstrengeling die ontstaat als één persoon deze verschillende rollen vervult, worden vaak genoemd als probleem. De voor- en nadelen van deze meervoudige rollen en de methodologische consequenties zijn in diverse onderzoeken beschreven (Akkerman, Bronkhorst, \& Zitter, 2011; Gendole, 2013; Kafyulilo, 2013; McKenney, Nieveen, \& van den Akker, 2006; Velthuis, 2014; Vervoort, 2013). Wij bepleiten dat het verenigen van de verschillende rollen in één persoon een kracht vormt en dat het tot de verantwoordelijkheid en deskundigheid van de onderzoeker behoort om een kritische rol te nemen in de beoordeling van de resultaten van de formatieve evaluatie. Een voorwaarde daarbij is wel dat de overwegingen en argumenten van de onderzoeker bij dit interpretatieproces helder worden gearticuleerd. In onze formatieve evaluatiestudies (zie hoofdstuk 4 en 5) is gepoogd het interpretatieve proces waarin verbeteringen voor het ontwerp tot stand komen, te expliciteren en daarmee een bijdrage te leveren aan de methodologie van formatieve evaluaties. Bovendien zijn in de studies waar mogelijk verschillende soorten databronnen (interviews, producten van studenten) en respondenten (studenten, docenten) betrokken om de validiteit van de evaluatieresultaten te bevorderen.

Bij het afleiden van verbeteringen uit de bevindingen is de volgende werkwijze gehanteerd. In de evaluatie van de praktische bruikbaarheid hebben de studenten en docenten verbetersuggesties gedaan, die niet onverkort zijn overgenomen door de onderzoeker. In het licht van de bedoeling van het ontwerp, heeft de onderzoeker 
een afweging gemaakt en vastgesteld of de verbetersuggestie, behalve haalbaar, ook wenselijk is. Ook de ervaringen met het onderwijsarrangement die studenten en docenten rapporteren, zijn door de onderzoeker geïnterpreteerd in het licht van de bedoeling van het ontwerp en hebben, bij discrepanties tussen uitgevoerd en beoogd curriculum, aanleiding gegeven tot verbeteringen die de onderzoeker zelf heeft geformuleerd.

Kortom, het komt de optimalisering van een ontwerp ten goede indien de onderzoeker een inhoudelijke rol neemt in het interpreteren van verbetersuggesties en ervaringen van gebruikers. Dit interpretatieproces dient dan wel transparant te zijn door een expliciet verwoord interpretatiekader te hanteren.

\subsection{Discussie van de effectmeting}

In deze paragraaf wordt eerst de opzet van de effectmeting toegelicht (8.4.1) en vervolgens worden de bevindingen bediscussieerd (8.4.2). Daarbij wordt het accent gelegd op het gebruik van concepten als wezenlijk aspect van cognitieve flexibiliteit.

\subsubsection{Opzet van de effectmeting}

In het onderzoek zijn twee effectmetingen uitgevoerd: in onderwijsarrangement 2 en 4. De bedoeling van de effectmetingen was inzicht te verkrijgen in de manier waarop cognitieve flexibiliteit bij studenten zich manifesteert in een vroeg stadium en in het eindstadium van de interventie. Daarom is gekozen voor een voornamelijk kwalitatieve onderzoeksmethode waarbij een beperkt aantal gevallen gedetailleerd is bestudeerd (zie hoofdstuk 6 en 7).

Figuur 8.1 biedt een overzicht van de opzet van de effectmeting. In de onderste balk is weergegeven in welke elementen cognitieve flexibiliteit is geoperationaliseerd. Cognitieve flexibiliteit is opgevat als beredeneerd professioneel handelen en is zichtbaar in de verantwoording van dat professioneel handelen. Daartoe zijn verschillende databronnen onderzocht in beide effectmetingen: een mondelinge presentatie met videobeelden van het professioneel handelen van studenten in effectmeting 1, een schriftelijke verantwoording met videobeelden van studenten in effectmeting 2. In Figuur 8.1 is dit in het rechtergedeelte zichtbaar.

In beide effectstudies is ook onderzocht in hoeverre studenten een professioneel discours ontwikkelden. Kenmerkend voor een professioneel discours is het gebruik van concepten in de onderlinge communicatie van vakgenoten over praktijksituaties. Het gebruik van concepten is onderzocht in (relatief) open en natuurlijke situaties waarin studenten met elkaar communiceren over hun professionele vaardigheden. De verschillende databronnen zijn in het linkergedeelte van Figuur 8.1 zichtbaar: in effectmeting 1 een mondelinge reflectie op professionele vaardigheden en in effectmeting 2 in een mondelinge samenvatting van een reflectief en collegiaal gesprek. 


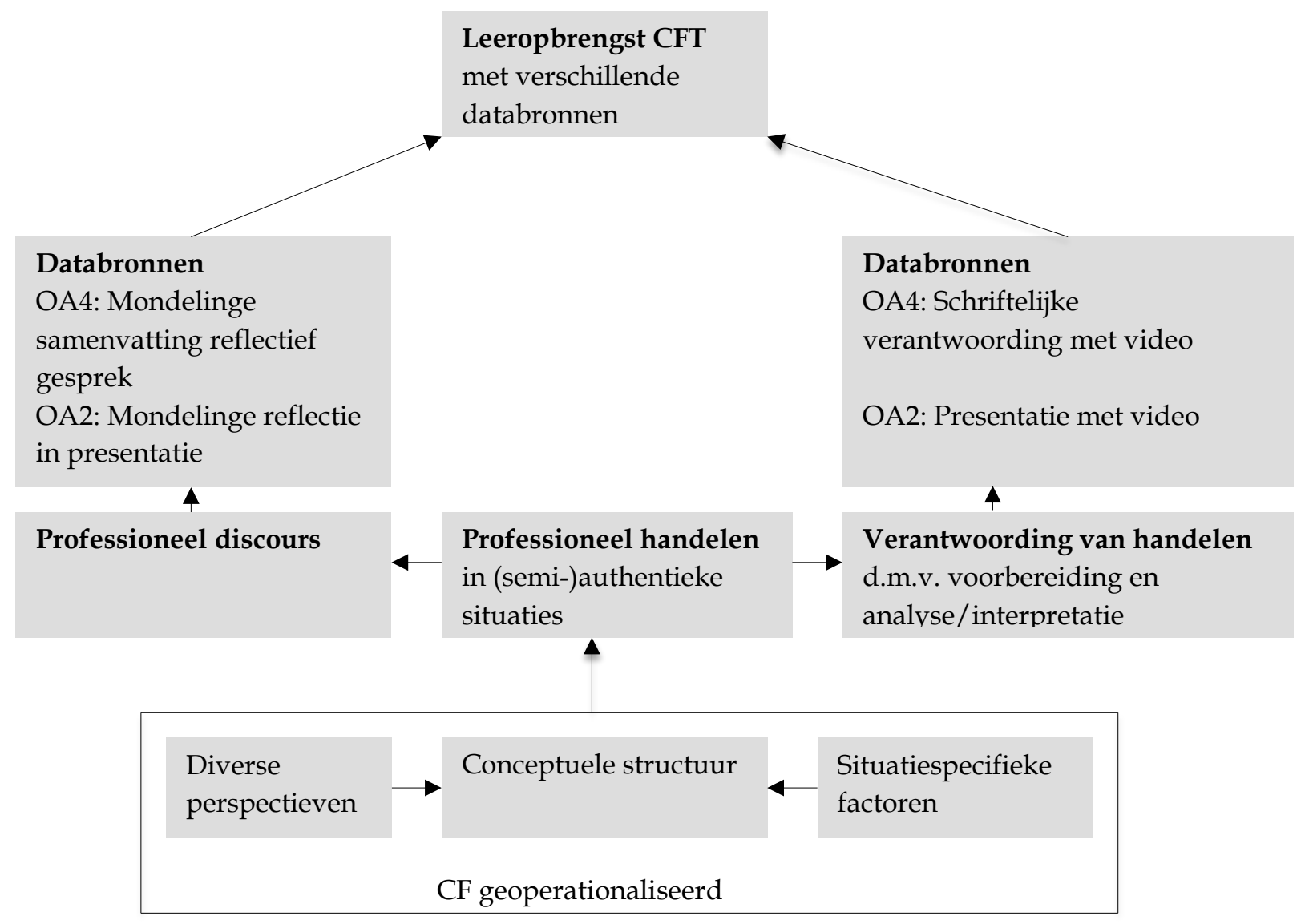

Figuur 8.1 Overzicht van de effectmeting

$\mathrm{CF}=$ cognitieve flexibiliteit; $\mathrm{OA}=$ onderwijsarrangement

\subsubsection{Bevindingen van effectmeting 1 en 2}

\section{Effectmeting 1}

In lijn met de opbouw van de interventie was de eerste effectmeting gericht op twee aspecten van cognitieve flexibiliteit, het hanteren van de conceptuele structuur en het innemen van diverse perspectieven in een semi-authentieke situatie. Voor deze effectmeting zijn twee studies uitgevoerd. In de eerste kwantitatieve studie is onderzocht in hoeverre studenten concepten hanteren bij de mondelinge toelichting op videobeelden van eigen professioneel handelen. De resultaten lieten zien dat aan een belangrijke voorwaarde voor de ontwikkeling van cognitieve flexibiliteit werd voldaan: studenten hanteren de conceptuele structuur. Bovendien bleek een groot deel van de studenten ook spontaan (dat wil zeggen, niet door de opdracht gestuurd) concepten te hanteren, wat een positief signaal was voor de verankering van concepten in het denken van studenten.

In de tweede studie is onderzocht op welke wijze en met welke kwaliteit de cognitieve flexibiliteit zich manifesteert om inzicht te krijgen in de ontwikkeling ervan. Daarom is een meervoudige gevalsstudie uitgevoerd, gericht op het gebruik van concepten en het innemen van diverse perspectieven. De uitersten van het 
spectrum werden in beeld gebracht door drie sterke en drie zwakke gevallen te analyseren. Deze analyse leverde een rijkgeschakeerd beeld op van de verschijningsvorm van cognitieve flexibiliteit in deze fase. (Voor een volledige beschrijving van de resultaten en conclusies wordt verwezen naar hoofdstuk 6, een kort beeld wordt hieronder geschetst).

Aan de ene kant van het spectrum bevond zich een groep studenten die uitstekend slaagde in de adequate interpretatie en betekenisvolle toepassing van de eerder geleerde conceptuele structuur, met een duidelijke tendens naar verklaring van hun professioneel handelen. De kwaliteit waarmee de conceptuele structuur werd gehanteerd kwam tot uitdrukking in een juiste interpretatie van de concepten en de betekenis die aan de concepten werd gegeven door consequent een concrete relatie te leggen met het eigen professioneel handelen. De resultaten van een aanvullende analyse (zie 6.8) lieten bovendien zien dat de kwaliteit waarmee de conceptuele structuur werd gebruikt, versterkt werd door bepaalde kwaliteitsbevorderende elementen die duiden op een diep begrip van concepten en wendbaarheid in de toepassing ervan (zoals bijvoorbeeld herhaaldelijke toepassing en concretisering van concepten in verschillende situaties). Ten slotte werden concepten ook spontaan en adequaat in de toelichting op het handelen geïntegreerd. Dit spontane gebruik van concepten duidt op vertrouwdheid met de conceptuele structuur.

Aan de andere kant van het spectrum bevonden zich studenten bij wie de toepassing van de conceptuele structuur sterke en zwakke kanten kende. Het professioneel handelen werd zowel beschreven als verklaard met concepten. Kenmerkend was dat de conceptuele structuur als geheel minder goed was ontwikkeld (fouten of hiaten bevatte) en dat relatie met het eigen handelen minder concreet werd gelegd. Positief was dat ook in de zwakke gevallen spontaan concepten werden gehanteerd, maar voor deze concepten golden dezelfde inhoudelijke beperkingen als voor de opdrachtgestuurde concepten. Gesignaleerd werd ten slotte dat in alle gevallen de redeneringen over de communicatieve situatie impliciet van aard waren en voor verbetering vatbaar.

De bevindingen maken duidelijk dat een deel van de studenten uitstekend presteert en dat een ander deel van de studenten moeite heeft met de adequate toepassing van de concepten. De verbetering van het voorafgaande inleidende onderwijsarrangement op basis van de formatieve evaluatie is voor een deel van de studenten niet voldoende gebleken om een stabiele conceptuele basis te bewerkstelligen. Dit is op zich niet verwonderlijk, aangezien de uitbreiding van de docentbegeleiding minimaal was vanwege de randvoorwaarden die voor de interventie golden.

Het tweede element van cognitieve flexibiliteit liet een positief beeld zien. Alle gevallen bleken de communicatieve situatie vanuit verscheidene perspectieven te belichten en een voor alle partijen bevredigende oplossing van het probleem te zoeken. Een deel van de studenten liet hier al zien oog te hebben voor het schoolorganisatieperspectief, een perspectief dat pas later in de interventie aan de orde komt. De kwaliteit waarmee de perspectieven werden ingenomen verschilde wel. 
Naast cognitieve flexibiliteit is ook de ontwikkeling van een professioneel discours onderzocht in de reflectie op het handelen. Hiervoor werd een positieve indicatie gevonden, aangezien alle gevallen spontaan concepten bleken op te nemen in de reflectie op hun handelen. In een incidenteel geval was zelfs sprake van transfer, in die zin dat een concept werd toegepast op een ervaring uit de beroepspraktijk. Het spontaan gebruik van concepten in de reflectie vormt, net als het spontaan gebruik in de toelichting, een aanwijzing dat studenten zich de conceptuele structuur eigen weten te maken en hun professioneel handelen beginnen te verantwoorden met behulp van concepten.

\section{Effectmeting 2}

In effectmeting 2 is vervolgens nagegaan hoe cognitieve flexibiliteit zich manifesteert in een authentieke situatie. Onderzocht werd in hoeverre studenten concepten en situatiespecifieke informatie verbinden in de onderbouwing van hun professioneel handelen én in hoeverre zij de perspectieven van ouder en school daarin betrekken. Daarvoor is een exploratieve, meervoudige gevalsstudie uitgevoerd.

Enerzijds lieten de resultaten zien dat in alle bestudeerde gevallen het beoogde niveau van cognitieve flexibiliteit werd bereikt. Studenten bleken hun professioneel handelen in een authentieke communicatieve situatie samenhangend te beredeneren met concepten en situatiespecifieke informatie. De wisselwerking tussen conceptueel kader en concrete situatie leidde tot een betekenisvolle onderbouwing van het handelen en werd beoogd door de interventie. Ook is gebleken dat alle studenten hun handelen onderbouwen en verantwoorden in redeneringen waarbij concepten of relevante situatiespecifieke informatie worden betrokken.

Tevens bleken alle studenten in staat tot perspectiefwisseling (ouder, school). Zij hadden oog voor de positie van de ouders in de communicatie, beseften het belang van een goede relatie tussen ouders en leerkracht en toonden een waarderende en respectvolle attitude. Aan deze attitude werd ook concreet vorm gegeven op handelingsniveau. Daarnaast expliciteerden zij het bredere kader waarbinnen communicatie met ouders plaatsvindt in de school en toonden hiermee organisatiebewustzijn als beginnend professional.

Anderzijds lieten de resultaten zien dat de kwaliteit van de bereikte cognitieve flexibiliteit varieert. Uit een vergelijking van goede en voldoende gevallen rees een beeld op van het spectrum waarbinnen de bereikte cognitieve flexibiliteit zich bevindt. De goede gevallen vertonen een consistent patroon van hoge kwaliteit op alle aspecten van cognitieve flexibiliteit. Bij de voldoende gevallen is dit beeld gevarieerder; ieder geval vertoont een uniek patroon met sterke en zwakke kanten. Duidelijk is geworden dat de kwaliteit van de bereikte cognitieve flexibiliteit afhankelijk is van de combinatie van een aantal aspecten. (Een volledige beschrijving van de conclusies is te lezen in paragraaf 7.4, hieronder worden drie aspecten in hoofdlijnen besproken).

Wat betreft het conceptgebruik kwam een beeld naar voren dat vergelijkbaar is met effectstudie 1. In de goede gevallen wordt een uitstekende beheersing van de conceptuele structuur getoond door middel van adequaat geïnterpreteerde concepten, het gebruik van subconcepten en het spontaan gebruik van concepten, 
maar in de voldoende gevallen wees het conceptgebruik ook op beperkingen. Positief was dat ook spontaan concepten worden gehanteerd. Elk geval toonde echter ook een zwak aspect aan het conceptgebruik zoals interpretatiefouten, weinig subconcepten of weinig spontaan gehanteerde concepten.

Verder werd opgemerkt dat de goede gevallen situatiespecifieke informatie vrijwel altijd opnemen in redeneringen over het handelen, terwijl de voldoende gevallen deze informatie vaker alleen beschrijven en minder vaak het hoogste niveau van redeneren bereiken waarin situatiespecifieke informatie en concepten samenhangend worden betrokken in een redenering. In effectmeting 1 was op dit vlak gesignaleerd dat het niveau van redeneren in alle gevallen te wensen overliet. Bij het innemen van het ouderperspectief viel op dat de kwaliteit hiervan bij de goede gevallen bijzonder hoog was. Bij de voldoende gevallen was de kwaliteit hiervan gevarieerder, van vergelijkbaar met de goede gevallen tot duidelijk zwakker.

Ten slotte is ook in effectmeting 2 de ontwikkeling van een professioneel discours onderzocht. Aansluitend op de studie in effectmeting 1 is nagegaan in hoeverre studenten concepten integreren in een mondelinge samenvatting van een reflectief gesprek over hun communicatie met ouders. In deze fase werd verwacht dat de conceptuele structuur dusdanig verankerd zou zijn dat studenten spontaan concepten zouden integreren in een open, informele taak. Alle gevallen bleken spontaan concepten te integreren in hun mondelinge samenvatting. De resultaten ondersteunen ook de ontwikkeling van cognitieve flexibiliteit doordat het merendeel van de gevallen in staat bleek te abstraheren van concrete situaties en generieke uitspraken te doen over communicatie met behulp van concepten.

\section{Gevolgtrekkingen}

Samenvattend hebben effectmeting 1 en 2 inzicht gegeven in de wijze waarop cognitieve flexibiliteit van studenten zich manifesteert. Op grond van de bevindingen stellen we ten eerste vast dat het mogelijk blijkt met deze interventie cognitieve flexibiliteit te ontwikkelen. Voor de ontwikkeling van een professioneel discours zijn bovendien overtuigende aanwijzingen gegeven.

Tegelijkertijd is opgemerkt dat binnen het beoogde niveau van cognitieve flexibiliteit grote variatie zichtbaar is in de kwaliteit van de leerresultaten - en dat met name de voldoende gevallen een grote bandbreedte in kwaliteit laten zien. Die bandbreedte wordt vooral bepaald door het uiteenlopende niveau in conceptgebruik en door beperkingen in de redeneringen met situatiespecifieke informatie - en minder sterk door het innemen van diverse perspectieven. Dit roept de vraag op hoe de kwaliteit van de cognitieve flexibiliteit nog verhoogd kan worden, zodat ook deze studenten het hoge niveau bereiken dat door sommigen al getoond wordt. Uit de eerste effectmeting bleek het gebruik van concepten voor een deel van de studenten ook al moeizaam te verlopen - en bleek redeneren in alle gevallen geen sterk punt. We leiden uit de bevindingen af dat een diepere verwerking van concepten in de verschillende fasen van het leerproces voor een deel van de studenten ondersteund zou moeten worden om de kwaliteit van het conceptgebruik - en daarmee van de 
onderbouwing van het professioneel handelen - verder te verbeteren. Bovendien is het zinvol meer ondersteuning te bieden aan het redeneren en argumenteren van studenten. Redeneren is een wezenlijk aspect van cognitieve flexibiliteit en casebased learning, omdat het de voorwaarde schept voor verder leren. Hoe beter de verschillende elementen van een casus expliciet met elkaar in verband worden gebracht, dat wil zeggen, hoe beter een casus wordt beredeneerd en begrepen, des te beter hij geïndexeerd kan worden in het geheugen en geschikt is als basis voor verder leren (Kolodner, 2006; Kolodner \& Guzdial, 2000; Kolodner et al., 2004). Het niveau van cognitieve flexibiliteit zou in het bijzonder verhoogd kunnen worden door het gebruik van concepten en het redenerend vermogen in samenhang te ondersteunen.

In de fase van het introductory learning zou meer ondersteuning geboden moeten worden. In de interventie werd een (te) groot beroep gedaan op de zelfstandigheid van studenten en kregen zij, vanwege de beperkende randvoorwaarden, slechts minimale ondersteuning door de docent bij het verwerven van die basis. Dit is voor een deel van de studenten niet effectief gebleken. Om studenten in deze fase een juist beeld te geven van het beoogde niveau van conceptgebruik en de beoogde wijze van redeneren, is het van belang voldoende ondersteuning te bieden bij het aanleren en toepassen van de conceptuele structuur op praktijksituaties - én te demonstreren hoe de verschillende aspecten van cognitieve flexibiliteit met elkaar interacteren. Het is passend bij de uitgangspunten van de cognitieve flexibiliteitstheorie om de wijze van denken en redeneren die bij een ill-structured vakgebied horen in een zo vroeg mogelijk stadium te leren. In de inleiding op een ill-structured vakgebied mag niet gesimplificeerd worden, omdat dit leidt tot een reductive bias en tot eenvoudige denkwijzen die geen recht doen aan de complexiteit van realistische situaties en later moeilijk zijn te vervangen (Jones \& Spiro, 1992; Spiro \& DeSchryver, 2009; Spiro et al., 1992; Spiro et al., 2007). De ondersteuning door de docent zal dan ook gericht moeten zijn op de verheldering van concepten enerzijds en het integreren van die concepten in interpretaties van complexe praktijksituaties anderzijds. Een belangrijk uitgangspunt is dat ook in deze fase geen deeltaken geïsoleerd kunnen worden ingeoefend; het is juist de bedoeling inzicht in de complexiteit te laten ontstaan. De rol van de docent is hierbij wezenlijk: eerstejaars studenten hebben voorbeelden nodig van interpretaties van een situatie met behulp van concepten om te kunnen inzien wat een dergelijke aanpak oplevert voor de kwaliteit van de interpretatie (modeling). Onderzoek van Eilam en Poyas (2006) ondersteunt het idee dat het gebruik van concepten in combinatie met het bereiken van inzicht in complexe situaties in de inleidende fase mogelijk is met een gerichte interventie.

Uit de effectmetingen blijkt dat er gradaties zijn in de beheersing van de conceptuele structuur in de fase van het advanced learning. Zo laat effectmeting 1 zien dat de overgang van introductory naar advanced learning niet voor alle studenten scherp is onderscheiden en (voor een deel van de studenten) een tussenfase kent, waarin de beheersing van de conceptuele structuur nog tot stand komt. Deze studenten zouden idealiter, in overeenstemming met de cognitieve flexibiliteitstheorie, meer situaties op 
hetzelfde niveau moeten interpreteren om de concepten beter te doorgronden (zie ontwerprichtlijn 2) alvorens zich uiteen te zetten met onderwijsarrangement 3 waarin de situaties complexer zijn. Bovendien is het wenselijk de rol van de docent te intensiveren door meer begeleiding op maat te introduceren, zodat studenten meer en sneller feedback krijgen tijdens het leerproces. Hiermee wordt aangesloten bij het onderzoek van Oonk (2009) dat uitwijst dat niveauverhoging van conceptgebruik voornamelijk plaatsvindt onder invloed van doelgerichte interventies van een opleider of docent. Deze vorm van begeleiding is tevens in overeenstemming met het 'zaagtandmodel' (cf. van Merriënboer) voor het leren van complexe vaardigheden: een taak van een bepaald niveau kan het beste worden geoefend met afnemende ondersteuning tot de taak zelfstandig kan worden uitgevoerd (Janssen-Noordman \& van Merriënboer, 2002).

In de interventie werd in beperkte mate ondersteuning gegeven aan de redeneer- en argumentatievaardigheden van studenten (met name in onderwijsarrangement 3). Om niveauverhoging te bereiken is ondersteuning door de docent op het gebied van argumenteren en redeneren wenselijk. Goede voorbeelden van expliciete redeneringen en feedback op het expliciteren van eigen redeneringen zouden studenten hierbij behulpzaam zijn. Oonk (2009) noemt de rol van de docent cruciaal voor de kwaliteit van studentactiviteiten, want hij constateert alleen niveauverhoging in het redeneren van studenten tijdens activiteiten met inbreng van een docent.

De aanbevelingen zijn, met het oog op de resultaten van effectmeting 2, ook van toepassing op de volgende onderwijsarrangementen van de interventie. In iedere volgende, complexere fase is het voor een deel van de studenten wenselijk meer cases te interpreteren en ondersteuning op maat van de docent te verkrijgen, omdat dit bijdraagt aan de verdieping van het conceptgebruik en aan adequate redeneringen over alle samenhangende aspecten van de communicatieve situatie.

\subsection{Bijdrage aan de cognitieve flexibiliteitstheorie}

Een essentieel aspect in het ontwerp is de opbouw in complexiteit in de fase van advanced learning - een opbouw die in de CFT ontbreekt en daarom beschouwd kan worden als een aanvulling op de CFT. De CFT beschouwt deze fase als tamelijk homogeen en geeft geen aanwijzingen voor de geleidelijke ontwikkeling van cognitieve flexibiliteit. In dit onderzoek is een curriculumontwerp gemaakt waarin de fase van advanced learning wel is gedifferentieerd, zodat studenten stapsgewijs cognitieve flexibiliteit kunnen ontwikkelen in relatie met het professioneel handelen. De opbouw is gezocht in de samenhang van toenemende complexiteit van praktijksituaties, professioneel handelen en cognitieve flexibiliteit.

Daarnaast kan dit onderzoek worden beschouwd als een eerste bijdrage aan het verkrijgen van empirische evidentie voor de werking van een interventie op basis van de CFT in de context van de professionele lerarenopleiding. Het leren van complexe vaardigheden is door Spiro \& DeSchryver (2009) vooral vanuit een ken- en leertheoretisch 
perspectief beschouwd. Enige empirische evidentie voor de werking van de CFT is gevonden in de universitaire lerarenopleiding voor het onderwerp leertheorie en klassenmanagement (Choi \& Lee, 2009; Derry \& StepTeam, 2003; Derry et al., 2006; Eilam \& Poyas, 2009; Siegel et al., 2000) in interventies waarbij studenten leren concepten te hanteren in analyses van videocases (van klassensituaties).

In dit onderzoek is voor het eerst de koppeling gemaakt tussen de CFT en de lerarenopleiding voor primair onderwijs. Spiro en DeSchrijver (2009) beweren dat alle professionele domeinen sterke kenmerken vertonen van ill-structuredness en noemen het onderwijs als voorbeeld hiervan. In een dergelijke lerarenopleiding staat het professioneel handelen centraal; daarom is in de interventie de ontwikkeling van cognitieve flexibiliteit gekoppeld aan de ontwikkeling van het eigen professioneel handelen van de student. De leeropbrengsten laten zien dat de interventie erin slaagt een betekenisvolle verbinding te bewerkstelligen tussen conceptuele kennis en professioneel handelen en dat het tonen van cognitieve flexibiliteit in authentieke situaties haalbaar is voor studenten. Studenten zijn in staat gebleken hun handelen te beredeneren met concepten en/of situatiespecifieke factoren en diverse perspectieven in te nemen, maar, afhankelijk van de kwaliteit van de student en van de situatie, zijn ook verschillen geconstateerd.

Het meten van cognitieve flexibiliteit in authentieke situaties brengt lastige kwesties met zich mee. Authentieke situaties zijn uniek, want ze zijn contextbepaald.

Dit betekent dat de situaties ongelijk zijn en dat de mate waarin studenten cognitieve flexibiliteit (kunnen) laten zien in de verantwoording van hun handelen mede wordt bepaald door de toevallige context. Zo geven bepaalde situaties met ouders meer aanleiding tot het betrekken van situatiespecifieke factoren in de verantwoording van het professioneel handelen dan andere situaties die meer standaard zijn. De ongelijkheid van de situaties maakt de resultaten dus niet zondermeer vergelijkbaar. Een meting in een gestandaardiseerde situatie zou echter afbreuk doen aan de bedoeling van de interventie: studenten voorbereiden op de beroepspraktijk. Ondanks de ongelijkheid van de situaties, is het van belang juist in authentieke situaties leerresultaten te meten, aangezien de essentie van cognitieve flexibiliteit ligt in de wijze waarop het professioneel handelen in realistische en deels onvoorspelbare praktijksituaties wordt verantwoord.

Dit onderzoek is uitgevoerd in één lerarenopleiding en levert een eerste bijdrage aan het verkrijgen van empirische gegevens voor de cognitieve flexibiliteitstheorie in deze context. Voor het versterken van de empirische basis van de CFT is het nodig om de theorie ook in andere beroepsopleidingscontexten te beproeven, met inachtneming van de specifieke kenmerken van die context (Plomp, 2013). Maar ook binnen de lerarenopleiding kan de theorie beproefd worden in andere vakgebieden dan communicatie met ouders. In dit onderzoek is een uitgebreide beschrijving gegeven van de context waarin het ontwerp heeft gefunctioneerd (thick description) en zijn de overwegingen, interpretaties en keuzes zoveel mogelijk geëxpliciteerd. Hiermee wordt analytische generaliseerbaarheid bewerkstelligd (Yin, 2009) en wordt de lezer de mogelijkheid geboden een vergelijking te maken en te beslissen welke aanpassingen gedaan moeten worden om het ontwerp bruikbaar te maken voor een andere situatie. 


\subsection{Aanbevelingen}

Het onderzoek heeft vragen beantwoord, maar ook kwesties aan het licht gebracht die nader onderzoek verdienen. In deze paragraaf worden aanbevelingen voor vervolgonderzoek gedaan (8.5.1) en worden de implicaties van het onderzoek voor de praktijk van de lerarenopleiding besproken (8.5.2).

\subsubsection{Vervolgonderzoek}

\section{Cognitieve flexibiliteit in beroepspraktijk}

Het lange-termijndoel van de CFT is transfer te bewerkstelligen, dat wil zeggen dat studenten ook in nieuwe situaties in staat zijn cognitieve flexibiliteit te tonen. In de interventie is transfer geïncorporeerd: de verschillende aspecten van cognitieve flexibiliteit worden steeds geoefend en toegepast op nieuwe situaties in onderwijsarrangement 1 tot en met 4 . De meest vergaande vorm van transfer vindt plaats in het laatste onderwijsarrangement waar studenten cognitieve flexibiliteit laten zien in een authentieke situatie (het uitvoeren van een beroepstaak in de basisschool met ouders). Dit proefschrift heeft betrekking op leraren-in-opleiding die in het kader van hun opleiding leertaken uitvoeren. Hoe de verdere ontwikkeling van cognitieve flexibiliteit plaatsvindt in de beroepspraktijk zal nader onderzocht moeten worden. In hoeverre blijven beginnende leraren hun professioneel handelen samenhangend beredeneren met concepten en situatiespecifieke informatie en vanuit diverse perspectieven? Welke invloed heeft de beroepscontext op het opmerken en selecteren van situatiespecifieke informatie van beginnende leraren?

Samenhangend hiermee zou de kwaliteit van het professioneel handelen zelf kunnen worden betrokken in vervolgonderzoek. In de beroepspraktijk worden vaardigheden door het opdoen van ervaring vanzelfsprekend verder ontwikkeld. Ons onderzoek heeft zich beperkt tot de onderbouwing van dat professioneel handelen en heeft geen inzicht gegeven in de vraag of, en in hoeverre, de kwaliteit van de onderbouwing samenhangt met de kwaliteit van het professioneel handelen zelf. Vervolgonderzoek zou dit kunnen uitwijzen.

\section{Professioneel discours in beroepspraktijk}

Een tweede aanbeveling voor vervolgonderzoek betreft de verhouding tussen conceptuele kennis en praktijkkennis in het discours van de (beginnende) professional. Het discours van leraren als beroepsgroep wordt in het algemeen niet gekenmerkt door het gebruik van concepten. Schwindt (2010) onderscheidt drie niveaus voor de mate waarin gebeurtenissen door leraren worden geïntegreerd in bovengeordende begrippen en vaktermen: (a) beschrijving, (b) integratie met Alltagskonzepte en (c) integratie met Fachkonzepte. Opgemerkt wordt dat leraren als beroepsgroep slechts in beperkte mate een gedeelde vaktaal (Fachkonzepte) hanteren. Bovendien is de kennis die in de praktijk wordt ontwikkeld, praktijkkennis, per definitie impliciet van aard en als zij al geëxpliciteerd wordt, dan gebeurt dit meestal niet in formele taal met concepten (Vervoort, 2013). Dit betekent dat studenten tijdens 
stages en na hun afstuderen in de beroepspraktijk geconfronteerd worden met een ander discours dan ze zelf krijgen aangeleerd. Deze situatie beperkt de kans op een voortzetting van het gebruik van concepten in de beroepspraktijk. Vervolgonderzoek, bijvoorbeeld in professionaliseringstrajecten van leraren, zou zich kunnen richten op de vraag hoe de ontwikkeling van praktijkkennis en conceptuele kennis plaatsvindt bij beginnende leraren en welke factoren bevorderend zijn voor een integratie van concepten in het discours.

\section{Digitale technologie}

Een derde aanbeveling voor vervolgonderzoek betreft de rol van digitale technologie als ondersteuning voor het verwerven van cognitieve flexibiliteit. In dit proefschrift is de ontwikkeling van een digitale concept map in beperkte mate gerealiseerd, maar gebleken is wel dat studenten de applicatie gebruikten voor het bestuderen van conceptuele kennis vanwege de eenvoudige toegankelijkheid en de just-in-time beschikbaarheid ervan (in tegenstelling tot papieren vakliteratuur). Digitale technologie biedt uitgebreide mogelijkheden om de complexiteit van concepten en van praktijksituaties op verschillende manieren te representeren en om een instructie vorm te geven die recht doet aan de kenmerken van ill-structured domeinen. Het verdient aanbeveling om in concreto te onderzoeken welke applicaties kunnen bijdragen aan het verwerven en toepassen van conceptuele kennis op een wijze die leidt tot een flexibele toepassing van die concepten. Een veelbelovende aanzet voor dergelijk onderzoek is gegeven in een onderzoeksproject waarin een digitale conceptuele structuur gecombineerd wordt met praktijkvoorbeelden en waarin wordt onderzocht hoe zo'n applicatie didactisch kan worden ingebed ter bevordering van advanced learning (Oude Engberink, 2014).

\subsubsection{Aanbevelingen voor de lerarenopleiding}

\section{Curriculumontwikkeling}

Leren op basis van de cognitieve flexibiliteitstheorie heeft ingrijpende implicaties voor de lerarenopleiding. Dit proefschrift heeft laten zien dat het mogelijk is een betekenisvolle verbinding te bewerkstelligen tussen conceptuele kennis en professioneel handelen, maar dit stelt wel enkele eisen aan het curriculum en de instructie.

Van belang is dat het curriculum een opbouw in complexiteit kent en dat de leertaken betrekking hebben op het professioneel handelen van de student. Daarnaast is van belang dat een vakgebied een heldere conceptuele structuur heeft geëxpliciteerd die consequent aan de leertaken wordt verbonden.

Uit het onderzoek is gebleken dat het verankeren van een conceptuele structuur (voor een deel van de studenten) een ingewikkeld proces is. Om de vereiste diepgang in de toepassing van de concepten te bewerkstelligen, is beperking van het aantal te leren concepten en herhaling in iedere fase van het curriculum wenselijk. De verwerving en toepassing van concepten vergt bovendien gerichte instructie in alle fasen van het leren. In de fase van introductory learning is het van belang de beheersing van concepten te bevorderen en hierbij voldoende ondersteuning te bieden. Tegelijkertijd dient in deze fase het zicht op de complexiteit van praktijksituaties ontwikkeld te 
worden en moet simplificatie worden voorkomen. In de fase van advanced learning is het van belang blijvende ondersteuning te bieden aan de conceptuele oriëntatie van studenten, in relatie met ondersteuning aan redeneervaardigheden om een goed begrip van complexe praktijksituaties te bevorderen.

De recente landelijke ontwikkeling van kennisbases voor de verschillende vakgebieden van het pabocurriculum vormt een belangrijke stap in het verhelderen van de conceptuele structuren van die vakgebieden. Deze kennisbases hebben een sturende invloed op de inhouden van de lerarenopleiding. Het gevaar is echter niet denkbeeldig dat de aandacht van de lerarenopleidingen eenzijdig gericht wordt op de verwerving en toetsing van de kennisbases met behulp van reproductieve toetsen. Beheersing van concepten is echter geen einddoel, maar slechts een voorwaarde voor het ontwikkelen van cognitieve flexibiliteit. Concepten dienen in de inleidende fase geleerd worden, zodat ze in de fase van advanced learning wendbaar gehanteerd kunnen worden om complexe praktijksituaties te begrijpen en het professioneel handelen te onderbouwen. Dit 'gevorderde leren' is het einddoel van de lerarenopleiding en behoeft nadrukkelijk aandacht in de vormgeving van het curriculum.

De commissie Kennisbasis Pabo (2011) pleit voor een beperking van het aantal kennisdomeinen én van de inhoud van de kennisbases om de studeerbaarheid van het pabocurriculum te bevorderen ${ }^{13}$. Op basis van dit proefschrift kan het pleidooi voor 'minder breedte, meer diepte' worden ondersteund. Het betekenisvol gebruik van concepten is haalbaar, maar vraagt beperking van het aantal concepten, een specifieke curriculumopbouw en een gerichte instructie waarvoor in ieder vakgebied een op maat gesneden oplossing gezocht zal moeten worden.

\section{Videocases}

Voor het vormgeven van een efficiënt en effectief leerproces is het aanbevelenswaardig videocases structureel te integreren in het curriculum van de lerarenopleiding. De inzet van videocases zorgt ervoor dat een rijk scala aan praktijksituaties binnen handbereik komt en voor bestudering toegankelijk is - en maakt het mogelijk een opbouw in complexiteit in een curriculum aan te brengen. Studenten worden met behulp van videocases in aanraking gebracht met situaties die zich in de beroepspraktijk niet altijd (op een gewenst moment) voordoen, zodat het leerproces niet afhankelijk is van zich toevallig voordoende situaties. De bestudering van videocases maakt het mogelijk binnen een beperkte opleidingstijd van vier jaar toch een breed beeld te verkrijgen van een domein. Juist omdat videocases, in tegenstelling tot authentieke situaties, niet dwingen tot onmiddellijk handelen zijn ze geschikt om van te leren. Naast bestudering van videocases biedt het produceren van videobeelden studenten de kans passend gedrag te oefenen in een veilige omgeving. Dit proefschrift heeft laten zien dat deze elementen tezamen videocases bijzonder geschikt maken als didactisch middel in het curriculum.

13 Zie hiervoor het advies Een goede basis (2011) van de Commissie Kennisbasis Pabo. 


\section{Beroepsveld}

Het is ten slotte aanbevelenswaardig dat de relatie tussen de initiële opleiding en het beroepsveld verder wordt geïntensiveerd om de begeleiding van studenten te verbeteren. Studenten worden in hun professionele ontwikkeling begeleid door lerarenopleiders en leraren uit het beroepsveld. Deze opleiders hebben een verschillende oriëntatie: instituutsopleiders zijn meer gericht op het beredeneren van het professioneel handelen met conceptuele kennis, schoolopleiders zijn meer gericht op het professioneel handelen in de dagelijkse praktijk en beschikken over contextspecifieke informatie en praktijkkennis. Voor het verbinden van conceptuele kennis en professioneel handelen (en het ontwikkelen van cognitieve flexibiliteit) is het noodzakelijk om beide invalshoeken te combineren. Daarom is het voor de begeleiding van studenten van belang dat er inhoudelijke afstemming plaatsvindt tussen instituutsopleiders en schoolopleiders - en dat er een wederzijdse erkenning is van ieders specifieke inbreng in het begeleidingsproces. Wanneer studenten bij hun professionele ontwikkeling worden begeleid door instituuts- en schoolopleiders die vanuit een gedeeld inhoudelijk referentiekader werken, zal dit bijdragen aan een effectiever leerproces. 


\section{REFERENTI ES}

Abell, S. K., Bryan, L. A., \& Anderson, M. A. (1998). Investigating preservice elementary science teacher reflective thinking using integrated media case-based instruction in elementary science teacher preparation. Science Education, 82, 491-510.

Akker, J. van den (2013). Curricular Development Research as a Specimen of Educational Design Research. In Tj. Plomp \& N. Nieveen (Eds.), Educational design research (pp. 53-70). Enschede: SLO. Geraadpleegd op: http://international.slo.nl/publications/edr/

Akker, J. van den, Gravemeijer, K., McKenney S., \& Nieveen, N. (Eds.). (2006). Educational design research, London: Routledge.

Akker, J. van den, Gravemeijer, K., McKenney S., \& Nieveen, N. (2006). Introducing educational design research. In J. van den Akker, K. Gravemeijer, S. McKenney, \& N. Nieveen (Eds.), Educational design research (pp. 3-7). London: Routledge.

Akkerman, S., Bronkhorst, L., \& Zitter, Y. (2013). The complexity of educational design research. Quality \& Quantity, 47, 421- 439. doi 10.1007/s11135-011-9527-9

Bakx, A., \& Berg, E. van den (Eds.). (2005). Van onderzoek naar leermateriaal. Coöperatiefleren met video's in lerarenopleidingen. Eindhoven: Fontys Hogescholen.

Bartlett, S., \& Burton, D. (2012). Introduction to education studies. Third edition. London: Sage Publications ltd.

Bereitner, C., \& Scardamalia, M. (1998). Beyond Bloom's taxonomy: Rethinking knowledge for the knowledge age. In A. Hargreaves, A. Lieberman, M. Fullan, \& D. Hopkins (Eds.), International handbook of educational change (pp. 675-692). Dordrecht: Kluwer Academic Publishers.

Berg, E. van den, Bakx, A., Thijs, A. M., \& Kemmeren, C. M. (2005). Co-operative learning with digital video in a hypermedia environment: A design-based research approach in teacher education. Paper gepresenteerd op EARLI-conference, Cyprus.

Berg, E. van den, \& Kwakman, K. (2004). Professionele ontwikkeling als kennisontwikkeling door leraren: naar een betere interactie tussen praktijk en theorie. VELON Tijdschrift voor Lerarenopleiders, 25(3), 6-12.

Berg, E. van den, Wallace, J., \& Pedretti, E. (2008). Multimedia cases, teacher education and teacher learning. In J. Voogt \& G. Knezek (Eds.), The international handbook of information technology (pp. 475-488). Dordrecht: Kluwer.

Berg, R. van den, \& VandenBerghe, R. (1995). Wegen van betrokkenheid: reflecties op onderwijsvernieuwing. Tilburg : Zwijsen

Berliner, D. C. (2001). Learning about and learning from expert teachers. International Journal of Educational Research, 35(5), 463-482. doi:10.1016/S0883-0355(02)00004-6

Blijleven, P. J. (2005). Multimedia-cases: naar een brug tussen theorie en praktijk (Academisch proefschrift). Enschede: Universiteit Twente. 
Borko, H. (2004). Professional development and teacher learning: Mapping the terrain. Educational Researcher, 33(8), 3-15.

Borko, H., Jacobs, J., Eitelborg, E., \& Pittman, M.E. (2008). Video as a tool for fostering productive discussions in mathematics professional development. Teaching and Teacher Education, 24, 417-436. doi:10.1016/j.tate.2006.11.012

Bransford, J., Derry, S., Berliner, D., Hammerness, K., \& Beckett, K.L.(2005). Theories of learning and their roles in teaching. In L. Darling-Hammond \& J. Bransford (Eds.), Preparing teachers for a changing world. What teachers should learn and be able to do (pp. 4087). San Francisco: Jossey-Bass.

Bransford, J., \& Schwarz, D. (1999). Rethinking transfer: A simple proposal with multiple implications. Review of Research in Education, 24, 61-100.

Bransford, J., Vye, N., Stevens, R., Kuhl P., Schwartz, D., Bell, P., Meltzoff, A., Barron, B., Pea, R., Reeves, B., Roschelle J., \& Sabelli, N. (2005). Learning theories and education: Toward a decade of synergy. In P. Alexander \& P. Winne (Eds.), Handbook of educational psychology (2nd Edition). (pp. 209-244). Mahwah, NJ: Erlbaum.

Brophy, J. (Ed.) (2004). Advances in research on teaching: Using video in teacher education, Vol. 10. Oxford, UK: Elsevier.

Brown, J. S., Collins, A., \& Duguid, P. (1989). Situated cognition and the culture of learning. Educational Researcher, 18(1), 32-42.

Burton, D., \& Bartlett, S. (2006). Practitioner research or descriptions of classroom practice? A discussion of teachers investigating their classrooms. Educational Action Research, 14(3), 395-405. doi:10.1080/09650790600847735

Calandra, B., Gurvitch, R., \& Lund, J. (2008). An exploratory study of digital video editing as a tool for teacher preparation. Journal of Technology and Teacher Education, 16(2), 137-153.

Calderhead, J. (1996). Teachers: Beliefs and knowledge. In D. C. Berliner \& R. C. Calfee (Eds.), Handbook of educational psychology (pp. 709-725). New York: Macmillan.

Chin, C., \& Chia, L. G. (2006). Problem-based learning: Using ill-structured problems in biology project work. Science Education 90, 44 - 67. doi 10.1002/sce.20097

Choi, I., \& Lee, K. (2009). Designing and implementing a case-based learning environment for enhancing ill-structured problem solving: classroom management problems for prospective teachers. Educational Technology Research \& Development, 57, 99-129. doi: $10.1007 /$ s11423-008-9089-2

Cochran-Smith, M. (2005). The new teacher education: For better or for worse? Educational Researcher, 34(7), 3-17. doi: 10.3102/0013189X034007003

Cochran-Smith, M., \& Lytle, S. (1999). Relationships of knowledge and practice: Teacher learning in communities. Review of Research in Education, 24, 249-305.

Cochran-Smith, M., \& Lytle, S. (2009). Inquiry as stance: Practitioner research for the next generation. New York: Teacher College Press.

Commissie Kennisbasis Pabo. (2012). Een goede basis. Advies van de Commissie Kennisbasis Pabo. Den-Haag: HBO-raad/Vereniging van hogescholen. Geraadpleegd op: http://www.vereniginghogescholen.nl/component/content/article/29/903

Darling-Hammond, L. (2006a). Constructing 21st-century teacher education. Journal of Teacher Education, 57(3), 300-314. doi: 10.1177/0022487105285962 
Darling-Hammond, L. (2006b). Powerful teacher education: Lessons from exemplary programs. San Francisco: Jossey-Bass.

Darling-Hammond, L., \& Hammerness, K. (2002). Toward a pedagogy of cases in teacher education. Teaching Education, 13(2), 125-135.

Darling-Hammond, L., Hammerness, K., Grossman, P., Rust, F., \& Shulman, L. (2006). The design of teacher education programs. In L. Darling-Hammond \& J. Bransford (Eds.), Preparing teachers for a changing world. What teachers should learn and be able to do (pp. 390441). San Francisco: Jossey-Bass.

Derry, S. J., Hmelo-Silver, C. E., Nagarajan, A., Chernobilsky, E., \& Beitzel, B. (2006). Cognitive transfer: Can we exploit new media to solve old problems on a large scale? Educational Computing Research, 35(2), 145-162.

Derry, S. J., Pea, R. D., Barron, B., Engle, R. A., Erickson, F., Goldman, R., Hall, R., Koschmann, T., Lemke, J. L. , Sherin, M. G., \& Sherin, B. L. (2010). Conducting video research in the learning sciences: Guidance on selection, analysis, technology, and ethics. The Journal of the Learning Sciences, 19(1), 3-53. doi: 10.1080/10508400903452884

Derry, S., \& STEP Team (2003). A case of theory-based web course design. In A. O'Donnell \& C. Hmelo (Eds.), Collaboration, reasoning and technology. Mahwah, NJ: Erlbaum.

Doyle, W., \& Ponder, G. (1977-1978). The practicality ethic in teacher decision-making. Interchange, 8, 1-12.

Eilam, B., \& Poyas, Y. (2006). Promoting awareness of the characteristics of classrooms' complexity: A course curriculum in teacher education. Teaching and Teacher Education, 22(3), 337-351

Ertmer, P. (2005). Teacher pedagogical beliefs: The final frontier in our quest for technology integration? Educational Technology Research \& Development, 53(4), 25-39.

Es, E. A. van, \& Sherin, M. G. (2002). Learning to notice: Scaffolding new teachers' interpretations of classroom interactions. Journal of Technology and Teacher Education, 10(4), 571-596.

Es, E. A. van, \& Sherin, M. G. (2008). Mathematics teachers' "learning to notice" in the context of a video club. Teaching and Teacher Education, 24, 244-276.

Es, E. A. van, \& Sherin, M. G. (2010). The influence of video clubs on teachers' thinking and practice. Journal of Mathematics Teacher Education, 13, 155-176. doi 10.1007/s10857-00991303

Gaikhorst, L. (2014). Supporting beginning teachers in urban environments. (Academisch proefschrift). Amsterdam: Universiteit van Amsterdam. Geraadpleegd op: http:/ /hdl.handle.net/11245/1.431994

Ge, X., \& Land, S. M. (2003). Scaffolding students' problem-solving processes in an illstructured task using question prompts and peer interactions. Educational Technology Research \& Development, 51(1), 2003, 21-38.

Geldens, J. (2007). Leren onderwijzen in een werkplekomgeving. Een meervoudige casestudy naar kenmerken van krachtige werkplekleeromgevingen voor aanstaande leraren basisonderwijs. (Academisch proefschrift). Helmond: Kempellectoraat, Hogeschool de Kempel. 
Gendole, A. A. (2013). Collaborative teacher professional development in Ethiopian higher education: The case of communicative language teaching. (Academisch proefschrift). Enschede: Universiteit Twente. doi 10.3990/1.9789036512602

Glaser, B. G., \& Strauss A. L. (1967). The discovery of grounded theory: Strategies of qualitative research. Chicago: Aldine Publishing Company.

Grossman, P., Hammerness, K., \& McDonald, M. (2009). Redefining teaching, re-imagining teacher education. Teachers and teaching: Theory and practice, 15(2), 273-289.

Henry, S. (2010). Talk that talk. A qualitative exploration of relevance and depth in elementary teachers' team conversations. Paper presented at the American Educational Research Association Annual Conference, Denver. April/May 2010.

Jacobson, M. J., \& Spiro, R. J. (1995). Hypertext learning environment, cognitive flexibility, and the transfer of complex knowledge: An empirical investigation. Journal of Educational Computing Research, 12, 301-333.

Janssen-Noordman, A. M., \& Merriënboer, J. J. van (2002). Innovatief onderwijs ontwerpen: via leertaken naar complexe vaardigheden. Groningen: Wolters Noordhoff.

Johnson, R. T., \& Johnson, D. W. (2002). An overview of cooperative learning. Retrieved from the web, December 20, 2003, from:www.cooperation.org/pages/overviewpaper.html

Jonassen, D. H. (1997). Instructional design models for well-structured and ill-structured problem-solving learning outcomes. Educational Technology Research \& Development, 45(1), 65-94.

Jones, R. A., \& Spiro, R. (1992). Imagined conversations: The relevance of hypertext, pragmatism, and cognitive flexibility theory to the interpretation of 'classic texts' in intellectual history. In Proceedings ACM Echt Conference, (pp. 141-148).

Kafyulilo, A. C. (2013). Collaborative design in teams to develop science and mathematics teachers' technology integration knowledge and skills. (Academisch proefschrift). Enschede: Universiteit Twente. doi 10.3990/1.9789036514903

Kemmeren, C. (2005). Colevi in de praktijk van een lerarenopleiding primair onderwijs. In A. Bakx \& E. van den Berg (Eds.), Van onderzoek tot leermateriaal. Coöperatief leren met video's in lerarenopleidingen (pp. 39-50). Eindhoven: Colevi.

Kessels, J., \& Korthagen, F. (1996). The relationship between theory and practice: Back to the classics. Educational Researcher, 25(3), 17-22.

Kesteren, B. J. van (1989). Gebruiksmogelijkheden van het Learner Report. Tijdschrift voor Onderwijsresearch, $n r .1,13-29$.

Kim, H., \& Hannafin, M. J. (2008a). Grounded design of web-enhanced case based activity. Educational Techology Research \& Development, 56(2), 161-179. doi 10.1007/s11423-0069010-9

Kim, H., \& Hannafin, M. J. (2008b). Situated case-based knowledge: An emerging framework for prospective teacher learning. Teaching and Teacher Education, 24, 1837- 1845. doi:10.1016/j.tate.2008.02.025

Kitchner, K. S. (1983). Cognition, metacognition, and epistemic cognition: A three-level model of cognitive processing. Human Development, 26(4), 222-232.

Kolodner, J. (2006). Case-based reasoning. In R. Keith Sawyer (Ed.), The Cambridge handbook of the learning sciences (pp. 225-242). Cambridge: Cambridge University Press. 
Kolodner, J., \& Guzdial, M. (2000). Theory and practice of case-based learning aids. In D. Jonassen \& S. M. Land (Eds.), Theoretical foundations of learning environments. Mahwah, NJ: Erlbaum.

Kolodner, J., Owensby, J., \& Guzdial, M. (2004). Case-based learning aids. In D. H. Jonassen (Ed.), Handbook of research on educational communications and technology (pp.829-861). Mahwah, NJ: Erlbaum.

Korthagen, F., \& Kessels, J. (1999). Linking theory and practice: Changing the pedagogy of teacher education. Educational Researcher, 29(4), 4-17.

Krathwohl, D. R. (1998). Methods of educational and social science research: An integrated approach. New York: Addison-Wesley Educational Publishers, Inc.

Labaree, D. F. (2003). The peculiar problems of preparing educational researchers. Educational Researcher, 32(4), 13-22.

Lave, J., \& Wenger, E. (1991). Situated learning: Legitimate peripheral participation. Cambridge, UK: Cambridge University Press.

Leeuw, E., Kemmeren, C. M., \& Berg, E. van den (2006). Inhouden digitaal toegankelijk. Eindrapportage. Interne publicatie van lectoraat Ict-rijke leeromgevingen. Hengelo: Hogeschool Edith Stein.

Lunenberg, M., Ponte, P., \& Ven, P. H. van de (2006). Waarom zouden docenten en opleiders geen onderzoek mogen doen? Een kennistheoretische verkenning. VELON Tijdschrift voor lerarenopleiders, 27(2), pp. 4-12.

McKenney, S., Nieveen, N., \& Akker, J. van den (2006). Design research from a curriculum perspective. In J. van den Akker, K. Gravemeijer, S. McKenney, \& N. Nieveen (Eds.), Educational design research (pp. 67-90). London: Routledge.

McKenney, S., \& Reeves, T. (2012). Conducting educational design research: What, why \& how. London: Routledge.

Meijer, P. C. (1999). Teachers' practical knowledge. Teaching reading comprehension in secondary education (Academisch proefschrift). Leiden: ICLON, Universiteit Leiden.

Merseth, K. K. (1996). Cases and case methods in teacher education. In J. Sikuka (Ed.), Handbook of research on teacher education (pp. 722-746). New York: Macmillan.

Miller, K., \& Zhou, X. (2007). Learning from classroom video: What makes it compelling and what makes it hard. In R. Goldman, R. Pea, B. Barron, \& S. Derry (Eds.), Video research in the learning sciences (pp. 321-334). Mahwah, NJ: Erlbaum.

Nieveen, N. (2009). Formative evaluation in educational design research. In Tj. Plomp \& N. Nieveen (Eds.), An introduction to educational design research (pp. 89-101). Enschede: SLO.

Nieveen, N., \& Folmer, E. (2013). Formative evaluation in educational design research. In Tj. Plomp \& N. Nieveen (Eds.), Educational design research (pp. 153-169). Enschede: SLO. Geraadpleegd op: http://international.slo.nl/publications/edr/

Novak, J. D. \& Canas, A. J. (2006). The theory underlying concept maps and how to construct them. Technical Report IHMC CmapTools. Florida Institute for Human and Machine Cognition, available at http://cmap.ihmc.us/Publications/Research/Papers/ TheoryUnderlyingConceptMaps.pdf

Oonk, W. (2009). Theory-enriched practical knowledge in mathemetics teacher education. (Academisch proefschrift). Leiden: ICLON, Universiteit Leiden. 
Oude Engberink, J. (2014). Transfer van theoretische concepten uit de Kennisbasis Nederlands naar de praktische uitvoering in de basisschool (ongepubliceerde masterthesis). Saxion, University of applied sciences, Hengelo.

Pareja Roblin, N. N., Ormel, B. J., McKenney, S. E., Voogt, J. M., \& Pieters, J. M. (2014). Linking research and practice through teacher communities: A place where formal and practical knowledge meet? European Journal of Teacher Education, 37(2). doi $10.1080 / 02619768.2014 .882312$

Patton, M. Q. (2002). Qualitative research \& evaluation methods. Thousands Oaks: Sage Publications.

Plomp, Tj. (2013). Educational design research: An Introduction. In Tj. Plomp, \& N. Nieveen (Eds.), Educational design research (pp. 11-50). Enschede: SLO. Geraadpleegd op: http://international.slo.nl/publications/edr/

Plomp, Tj., \& Nieveen, N. (Eds.). (2009). An introduction to educational design research (pp. 89101). Enschede: SLO.

Plomp, Tj., \& Nieveen, N. (Eds.). (2013). Educational design research. Enschede: SLO. Geraadpleegd op: http://international.slo.nl/publications/edr/

Ponte, P. (2002). Actieonderzoek door docenten: uitvoering en begeleiding in theorie en praktijk. Dissertatie. Apeldoorn, Leuven: Garant.

Putnam, R. T., \& Borko, H. (2000). What do new views of knowledge and thinking have to say about research on teacher learning? Educational Researcher, 29(1), 4-15.

Rosaen, C., Lundeberg, M., Cooper, M., Fritzen, A., \& Terpstra, M. (2008). Noticing noticing: How does investigation of video records change how teachers reflect on their experiences? Journal of Teacher Education, 59(4), 347-360. doi: 10.1177/0022487108322128

Santagata, R. (2009). Designing video-based professional development for mathematics teachers in low-performing schools. Journal of Teacher Education, 60(1), 38-51.

Schwarz, D., Bransford, J., \& Sears, D. (2005). Efficiency and innovation in transfer. In J. Mestre (Ed.), Transfer of learning from a modern multidisciplinary perspective, 1-51. Mahwah, NJ: Erlbaum.

Schwartz, D. L., \& Hartman, K. (2007). It's not television anymore: Designing digital video for learning and assessment. In R. Goldman, R. Pea, B. Barron, \& S. Derry (Eds.), Video research in the learning sciences (pp. 335-348). Mahwah, NJ: Erlbaum.

Schwindt, K. (2008). Lehrpersonen betrachten Unterricht: Kriterien für die kompetente Unterrichtswahrnehmung. Münster, Germany: Waxmann.

Schön, D. A. (1987). Educating the reflective practitioner: Toward a new design for teaching and learning in the professions. San Francisco, Jossey-Bass.

Seidel, T., Stuermer, K., Blomberg, G., Kobarg, M., \& Schwindt, K. (2011). Teacher learning from analysis of videotaped classroom situations: Does it make a difference whether teachers observe their own teaching or that of others? Teaching and Teacher Education, 27(2), 259-267. doi:10.1016/j.tate.2010.08.009

Sherin, M. G., \& Han, S. Y. (2004). Teacher learning in the context of a video club. Teaching and Teacher Education, 20(2), 163-183. 
Sherin, M. G., Linsenmeier, K. L., \& Es, E. A. van (2009). Selecting video clips to promote mathematics teacher' discussions of student thinking. Journal of Teacher Education, 60(3), 213-230.

Shin, N., Jonassen, D. H., \& McGee, S. (2003). Predictors of well-structured and ill-structured probem solving in an astronomy simulation. Journal of Research in Science Teaching, 40(1), 6-33.

Shulman, J. (1992). Case methods in teacher education. New York: Teacher College Press.

Shulman, L. S. (1992). Toward a pedagogy of cases. In J. H. Shulman (Ed.), Case methods in teacher education (pp.1-29). New York: Teachers College Press.

Shulman, L. S. (1996). Just in case: Reflections on learning from experience. In J. A. Colbert, P. Desherg, \& K. Trimble (Eds.), The case for education: Contemporary approaches for using case methods (pp. 197-217). Boston: Allyn and Bacon.

Siegel, M., Derry, S., Kim, J. B., Steinkuehler, C., Street, J., Canty, N., Fassnacht, C., Hewson, K., Hmelo, C., \& Spiro, R. (2000). Promoting teachers' flexible use of the learning sciences through case-based problem solving on the www: A theoretical design approach. In B. Fishman \& S. O'Connor-Divelbiss (Eds.), Fourth international conference of the learning sciences (pp. 273-279). Mahwah, NJ: Erlbaum.

Spiro, R. J., Collins, B. P., \& Ramchandran, A. R. (2006). Modes of openness and flexibility in 'Cognitive Flexibility Hypertext' learning environments. In B. Khan (Ed.), Flexible learning in an information society (pp.18-25). Hershey, PA: Information Science Publishing.

Spiro, R. J., Collins, B. P., \& Ramchandran, A. R. (2007). Reflections on a post-Gutenberg epistemology for video use in ill-structured domains: Fostering complex learning and cognitive flexibility. In R. Goldman, R. Pea, B. Barron, \& S. J. Derry (Eds.), Video research in the learning sciences (pp. 93-100). Mahwah, NJ: Erlbaum.

Spiro, R. J., Collins, B. P., Thota, J. J., \& Feltovich, P. J. (2003). Cognitive flexibility theory: hypermedia for complex learning, adaptive knowledge application, and experience acceleration. Educational technology 44(5), 5-10.

Spiro, R. J., Coulson, R. L., Feltovich, P. J., \& Anderson, D. (1988). Cognitive flexibility theory: Advanced knowledge acquisition in ill-structured domains. In V. Patel (Ed.), Proceedings of the 10th Annual Conference of the Cognitive Science Society (p. 375-383). Hillsdale, NJ: Erlbaum.

Spiro, R. J., \& DeSchryver, M. (2009). Constructivism. When it's the wrong idea and when it's the only idea. In S. Tobias \& T. M. Duffy (Eds.), Constructivist instruction. Succes or failure? (pp. 106-123). New York and London: Routledge.

Spiro, R. J., Feltovich, P. J., Coulson, R. L., \& Anderson, D. (1989). Multiple analogies for complex concepts: Antidotes for analogy-induced misconception in advanced knowledge acquisition. In. S. Vosniadou \& A. Ortony (Eds.), Similarity and analogical reasoning (pp. 498-531). Cambridge: Cambridge University Press.

Spiro, R .J., Feltovich, P. J., Jacobson, M. J., \& Coulson, R. L. (1992). Cognitive flexibility, constructivism and hypertext: Random access instruction for advanced knowledge acquisition in ill-structured domains. In T. Duffy \& D. Jonassen (Eds.), Constructivism and the technology of instruction (p. 57-75). Hillsdale, NJ: Erlbaum. [Reprinted from a special issue of the Journal Educational Technology on Constructivism, 1991] 
Staman, L. (2009). Competentiebeoordeling aan de hand van videobewijs. Een case study bij een lerarenopleiding basisonderwijs. (Ongepubliceerde masterthesis). Universiteit Utrecht.

Stockero, S. M. (2008). Using a video-based curriculum to develop a reflective stance in prospective mathematics teachers. Journal of Mathematic Teacher Education, 11, 373-394. doi: $10.1007 /$ s10857-008-9079-7

Tessmer, M. (1993). Planning and conducting formative evaluations. Improving the quality of education and training. London: Kogan Page.

Thijs, A. (2005). Kwaliteitsmeting Colevi-project: resultaten van een expertevaluatie. Enschede: Universiteit Twente.

Veen, K. van, Zwart, R. C., Meirink, J. A., \& Verloop, N. (2010). Professionele ontwikkeling van leraren: een reviewstudie naar effectieve kenmerken van professionaliseringsinterventies van leraren. Leiden: ICLON/Expertisecentrum Leren van Docenten.

Velthuis, C. (2014). Collaborative curriculum design to increase science teaching self-efficacy. (Academisch proefschrift). Enschede: Universiteit Twente. doi 103990/1.9789036536684

Vervoort, M. (2013). Kijk op de praktijk. Rich media-cases in de lerarenopleiding (Academisch proefschrift). Enschede: Universiteit Twente. doi: 10.3990/1.9789036535533

Wallace, J. (2002). Introduction: Science teaching cases as learning opportunities. Research in Science Education, 31(2), 185-190.

Wenger, E., McDermott, R., \& Snyder, W. M. (2002). Cultivating Communities of Practice. Boston: Harvard Business School Press.

Wet op de beroepen in het onderwijs. (2006). Geraadpleegd op: http://wetten.overheid.nl/BWBR0016944

Yerrick, R., Ross, D., \& Molebash, Ph. (2005). Too close for comfort: Real-time science teaching reflections via digital video editing. Journal of Science Teacher Education, 16(4), 351-375.

Yin, R. K. (2009). Case study research. Design and methods (4th ed.). Thousand Oaks: Sage Publications.

Zhang, M., Lundeberg, M., Koehler, M., \& Eberhardt, J. (2011). Understanding affordances and challenges of three types of video for teacher professional development, Teaching and Teacher Education, 27(2), 454-462. doi 10.1016/j.tate.2010.09.015

Zwart, R., Lunenberg, M., \& Volman, M. (2010). Inleiding op het themanummer: onderzoekende leraren en lerarenopleiders. Pedagogische Studiën, 87(4), 227-231. 


\section{ENGLI SH SUMMARY}

\section{Towards a meaningful interaction between theory and practice in teacher education}

This thesis explores how a meaningful interaction between theory and practice in teacher education can be established. To that end a four-year curriculum on teacher communication competencies was developed, evaluated and implemented in a design research project.

\section{Background of the study}

Teachers are expected to be competent and sensible professionals capable of handling a wide range of real-life situations as well as reasoning about the grounds for their decision-making and action. A major goal of teacher education therefore is to teach students how to justify their professional practice using a conceptual knowledge base. However, the transfer of theory into practice in order to create a knowledgebased professional practice is a challenging problem and has not yet been solved satisfactorily. Furthermore, student teachers, teacher educators and teachers find a discrepancy in the theoretical insights provided in teacher education and the required competencies for situations in daily professional practice.

This study focuses on the problematic relation between theory and practice in teacher education, described in short as the 'theory-practice issue'. The aim of the study is to find a way to establish a meaningful relation between conceptual knowledge and professional practice. The general research question being addressed is: How can a meaningful interaction between conceptual knowledge and professional practice be established? In the study 'conceptual knowledge' is used as an overall term covering the body of theoretical knowledge in (a domain of) the teacher education curriculum. The study, conducted in the context of pre-service teacher education, focuses on the subject matter of teacher communication competencies (i.e. communication with parents).

The theory-practice issue is considered within the framework of the Cognitive Flexibility Theory (CFT) and central ideas about case-based learning, case-based reasoning and learning with video cases (Chapter 2). CFT as a theory of learning and instruction is especially concerned with the application of conceptual knowledge in realistic and complex situations. The general objective is the acquisition of transferable knowledge in order to understand complex real-world situations (i.e. illstructured problems) while taking into account the specific elements of each unique situation. Responsive approaches to the context and a flexible application and combination of complex concepts from several conceptual domains are typical elements of cognitive flexibility. The theory provides for a useful insight into the interrelated components constituting the complexity of knowledge application. 
CFT features advanced learning as a particular stage in the learning process in between introductory and expert learning. Advanced learning and its learning goals of mastery of complexity and transfer are of great importance to teacher education programmes, as prospective teachers need a flexible knowledge base that can be adapted and applied to diverging situations.

Within CFT a case-based learning process is considered the most promising and appropriate way to prepare prospective teachers for a knowledge-based teaching practice. Literature shows that case-based learning has the potential to foster a meaningful interaction between conceptual knowledge and professional practice as it allows one to go back and forth from general concepts to specific details of a realistic situation. Using video cases has the additional advantage of showing a realistic context and providing a lot of detailed information including non-verbal communication.

\section{Aim of the study and research approach}

A design research approach was adopted for the study. Design research combines design, evaluation and research activities in order to systematically develop solutions (interventions) for realistic educational problems. In this study an intervention was developed for and implemented in a teacher education programme. Pre-requisites for the intervention were correspondence to the existing programme, a competencebased approach and a limited amount of credits (teaching time).

The aim of this study was twofold. In the first place designing and evaluating an intervention supporting a learning process focused on a meaningful interaction between conceptual knowledge and professional practice. It was operationalised in terms of cognitive flexibility. Subsequently the study aimed at gaining insight into the learning process and the manifestation of student teachers' cognitive flexibility. A secondary goal of the intervention was to foster a professional discourse among student teachers. The use of concepts is typical for the communication about professional issues among professionals. As the use of conceptual knowledge is a central element of cognitive flexibility, it should therefore be seen in connection with the intervention's main goal. In this study it was hypothesized that the development of cognitive flexibility might contribute to the development of a professional discourse. Consequently the study also aimed to gain insight into student teachers' professional discourse.

In the second place the study aimed at contributing to the cognitive flexibility theory by testing it in the context of a professional teacher education program. While CFT's roots lie mainly in the (American) academic context, what is new in this study is that CFT-principles are operationalised for a context where professional practice is key. 


\section{Research design}

This research project took place in three phases. In the first phase the intervention was developed systematically. Design guidelines were derived from a literature study (Chapter 2) and operationalised in a detailed four-year curriculum and instructional design about teacher communication with parents for student teachers in their first, second, third and fourth year of the program (Chapter 3).

In the second phase the intervention was evaluated formatively with aim of optimising and improving the intervention and gaining a first insight into the intervention's potential. Because each part of the intervention was implemented in the regular curriculum of a teacher education's institute, the (successive) formative evaluation studies were conducted in a realistic and large-scale setting. Studies on the actual practicality (Chapter 4) and on the learning outcomes (Chapter 5) of the intervention's four constituting teaching arrangements were conducted. Data were collected through interviews, student document analysis and observation among student teachers and teacher educators and analysed qualitatively.

In the third phase the effect of two different teaching arrangements of the intervention was evaluated. Figure 1 gives an overview of these effect studies.

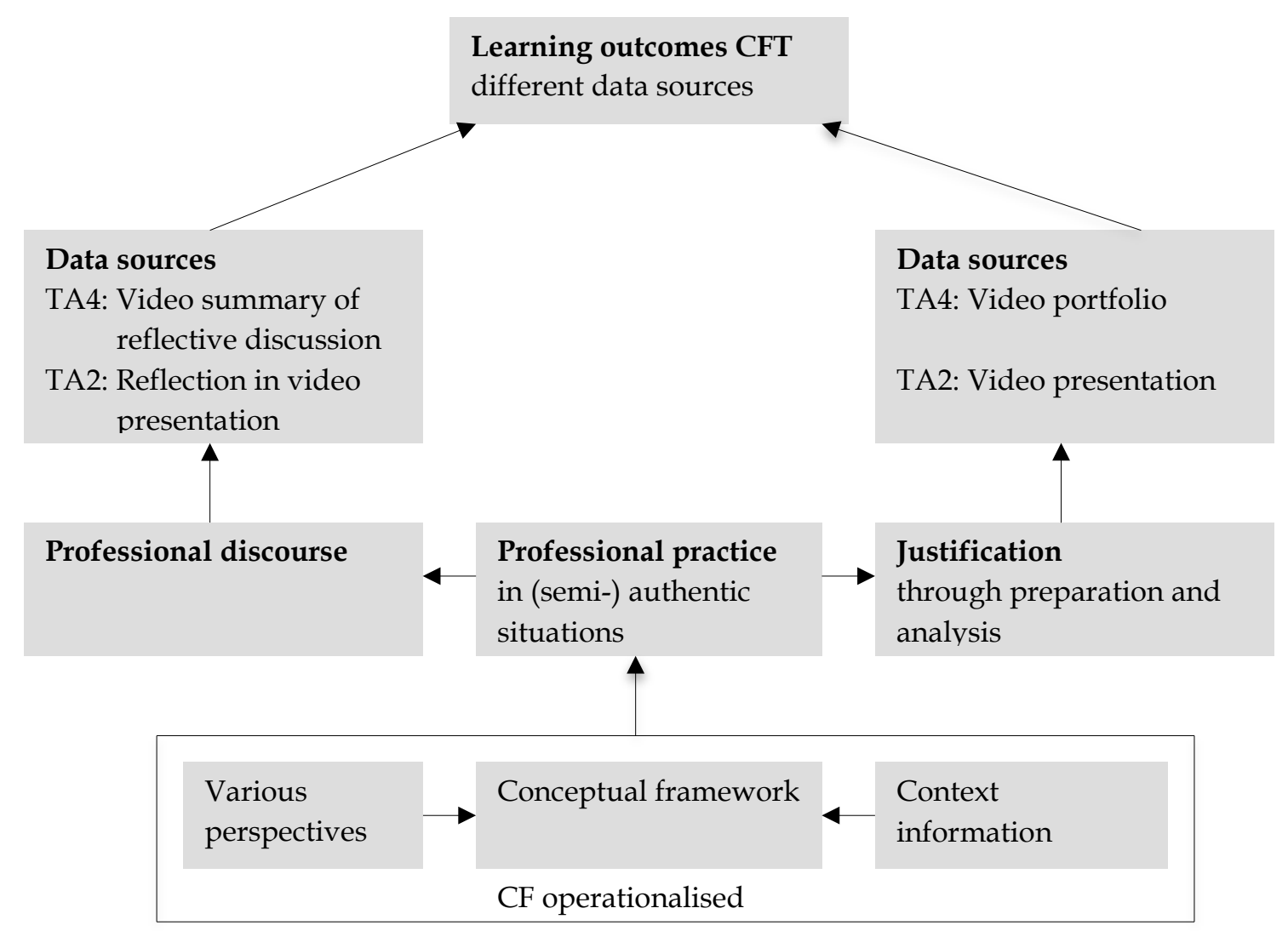

Figure 1 Overview of effect studies

$\mathrm{CF}=$ cognitive flexibility; $\mathrm{TA}=$ teaching arrangement 
One effect study related to teaching arrangement 2 for second-year students (Chapter 6 ), the next effect study related to teaching arrangement 4 for fourth-year students (Chapter 7). These studies contributed to gaining insight into the learning process and the quality of the students' learning outcomes in a fairly early and in the last stage of the intervention. In this phase student documents were analysed mainly qualitatively. Simultaneously to studying learning outcomes in terms of cognitive flexibility, the development of a professional discourse among student teachers was studied in both effect studies.

\section{Curriculum and instructional design}

In this study cognitive flexibility in the domain of communication is operationalised as knowledge-based justification of professional practice, consisting of three elements: (a) reasoning about one's professional practice and using a conceptual framework,

(b) taking into account various stakeholders' perspectives on the situation, and (c) specific context information.

The curriculum and instructional design consist of four consecutive teaching arrangements. The intervention as a whole had the purpose of facilitating a meaningful interaction between conceptual knowledge and, increasingly complex realistic (communicative) situations in a case-based learning process. Typical elements of the overall curriculum design are:

- increasing complexity

- realistic video cases of communicative situations

- a concept map.

Figure 2 shows the integrated elements of the curriculum design. Video cases representing reality and a concept map representing a conceptual framework were integrated in the teaching arrangements. The same conceptual framework was consistently and repeatedly used in the four consecutive teaching arrangements in order to optimise the chance of anchoring the conceptual framework in the student teacher's long-term memory. Increasing complexity in the curriculum was found in (a) the communicative situation itself, (b) the considered perspectives or points of view on the situation, (c) the amount of concepts applied for analysis of the situation and (d) the context for demonstrating professional communicative skills (this context changes from semi-authentic to authentic situations).

Learning goals are increasing in complexity - in accordance with the development of (various aspects of) cognitive flexibility. 


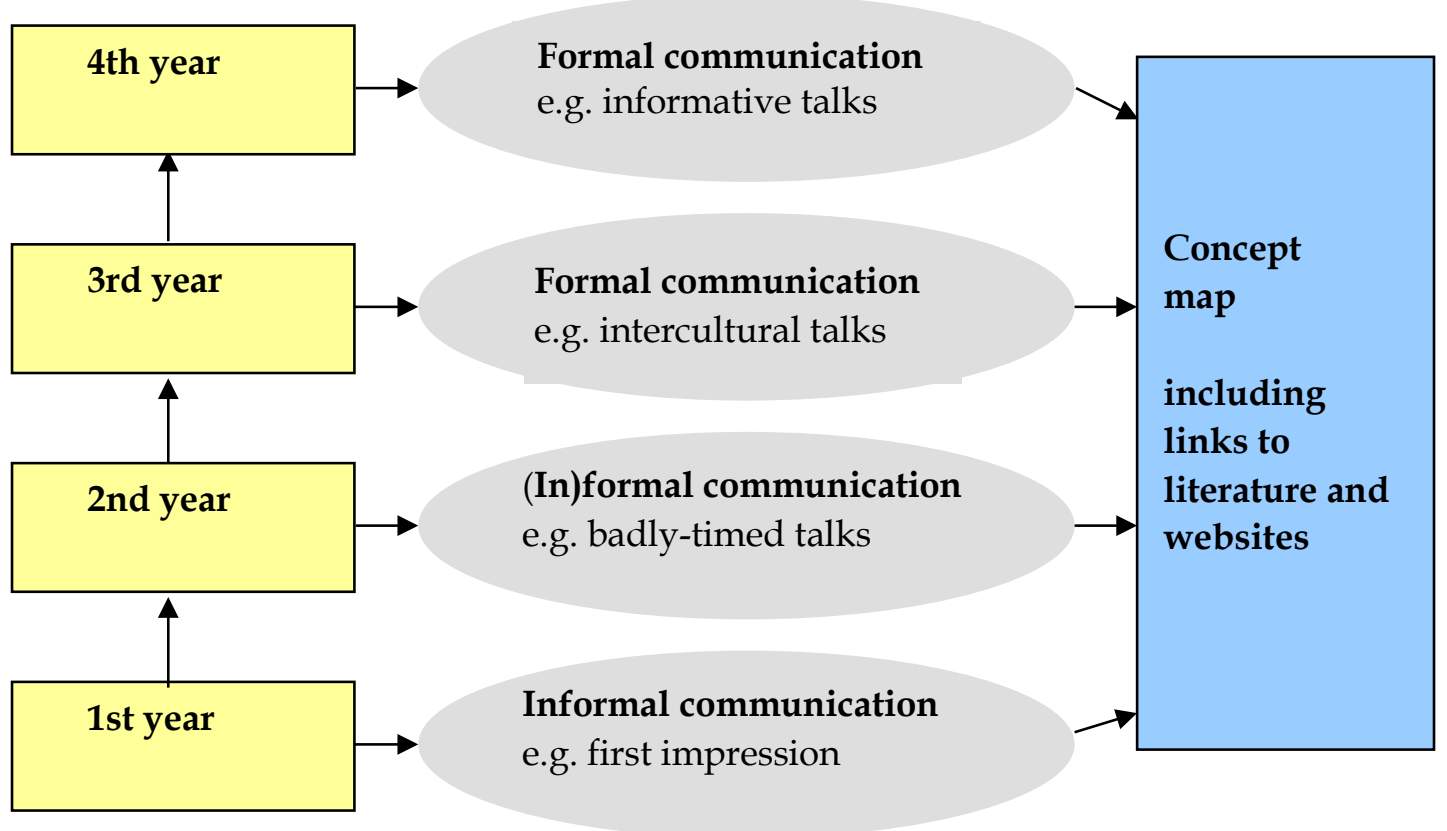

Figure 2 Integration of video cases and concept map in the curriculum design

In the instructional design conceptual knowledge and professional practice are intertwined through two central learning tasks: video case-analysis and video production. Typical elements of the instructional design are:

- video case-analysis and video production of one's own communicative skills, based on a pedagogical model;

- consistent integration of the conceptual structure in all learning tasks;

- interaction between peers, teacher educators and teachers and cooperative learning.

CFT hypothesizes that cognitive flexibility follows from studying realistic video cases. In this thesis it was assumed that the combination of elements, in particular video production including a knowledge-based justification of one's own professional practice, and the consistent use of a conceptual structure in all learning tasks contribute to a knowledge-based professional practice.

\section{Development of the intervention}

The formative evaluation studies of the practicality of the intervention resulted in improvement of the digital concept map and detailed improvements of learning materials and assessment procedures (instrumentality). A substantial improvement was the addition of the fourth teaching arrangement to the initial curriculum design in order to support the development of communicative skills in challenging contexts for prospective teachers. One critical element was also pointed out: some student teachers needed more support for the initial acquirement (introductory learning) and further application of the conceptual framework (advanced learning). Within the contextual conditions it was possible only to add a minimum of additional support. 
Furthermore, teacher educators and student teachers reviewed the intervention positively: teacher educators appreciated the new working method and carried it out as was intended (congruence). They reported an exceptionally enthusiastic response from student teachers during classes. Student teachers appreciated the efficient use of classroom time, the video production and the assessment with presentations.

The potential effectiveness of the intervention was evaluated positively. Results showed that student teachers were able to use concepts in their justification of professional practice, although quality varied. This finding was confirmed by the evaluation of the intervention's practicality.

\section{Results}

Learning outcomes in terms of cognitive flexibility were subsequently studied in teaching arrangement 2 and 4 (see Figure 1). Both effect studies generated a detailed insight in the manifestation of cognitive flexibility. The findings suggested that the intervention was successful in creating a meaningful relation between conceptual knowledge and professional practice.

The first effect study focused on two elements of cognitive flexibility: application of concepts and taking perspectives. The results from a quantitative study clearly showed that the main condition for developing cognitive flexibility had been fulfilled: Student teachers used concepts for reasoning about their professional practice. Furthermore, they used concepts spontaneously, i.e. concepts that were not explicitly part of the assessment criteria, indicating that the conceptual framework was becoming a natural element of their vocabulary.

The next question was how and with what quality cognitive flexibility was demonstrated. Results from a multiple case study gave rise to a detailed picture of cognitive flexibility. With regard to the application of concepts, on one side of the spectrum a group of student teachers was perfectly able to adequately interpret and apply the conceptual framework in a meaningful way to their professional practice with a tendency to explaining. A deep understanding of concepts was shown through repeated use in different contexts and spontaneous use of concepts. On the other end of the spectrum, a group of student teachers showed a reasonable but not flawless comprehension of the conceptual framework. Concepts were applied to their professional practice, often in a more describing (and less explanatory) way. Concepts were also used spontaneously but the interpretation was less comprehensive. As a whole the conceptual framework was developed less comprehensively and accurately.

With regard to perspective-taking the findings were positive. All student teachers were able to take into account the parents' perspective and interests - and searched for solutions that were satisfying for all parties. Some took into account the school's or child's perspective as well.

In the final effect study cognitive flexibility was demonstrated in a real-life situation (a conversation with parents in a primary school). The study involved investigating to what extent the three elements of cognitive flexibility - use of concepts, context 
information and taking (parents' and school's) perspectives - were taken into account in student teachers' justification of professional practice.

Results from a multiple case study showed that the target level of cognitive flexibility had been achieved in all cases. This meant that student teachers were able to reason consistently with concepts and relevant context information (about their own professional practice), indicated as the highest level of reasoning. The interaction between concepts and context resulted in a meaningful use of concepts and an understanding of the situation. Furthermore, all student teachers showed the ability to take various perspectives - and to respond professionally to the situation. A professional attitude towards parents' concerns and awareness of the broader school perspective, including school policy and organisational interests, were manifested.

The results also showed a wide range of quality in the achieved cognitive flexibility. A comparison of good and average cases led to the following characterisation. The good cases demonstrated a consistent pattern of high quality in all constituting elements of cognitive flexibility. The adequate combination of high quality elements led to high quality cognitive flexibility. In the average cases the picture was more varied: each case demonstrated a unique mix of strong and weak elements; weak elements were particularly found in the comprehension of concepts and the level of reasoning; strong elements were particularly found in the spontaneous use of concepts, the different perspectives and responsiveness to the situation. The findings are in line with previous findings in the formative evaluation and the first effect study. Therefore it is advisable - to further enhance the quality of cognitive flexibility - to support the acquirement (introductory learning) and application of the conceptual structure more extensively and to support argumentative skills (advanced learning).

With regard to the development of a professional discourse, both effect studies investigated the use of concepts in relatively open and informal situations. The use of concepts was not guided by learning tasks in these situations and therefore indicates to what extent student teachers had adopted the conceptual framework. Findings in both studies indicated the spontaneous integration of concepts in the student teachers' vocabulary and the ability to generalise from specific situations with the use of concepts. These findings convincingly suggest the development of a professional discourse - and support the development of cognitive flexibility as well.

\section{Pay-off}

The research in this thesis resulted in multiple pay-offs.

1. A four-year curriculum and instructional design.

The design was developed systematically and its practicality was proven. It was implemented in a regular teacher education programme and proved to be successful in fostering cognitive flexibility - and consequently in establishing a meaningful interaction between conceptual knowledge and professional practice. The curriculum and instructional design, including video cases, concept map, learning tasks, and assessment criteria can be considered practical outcomes of the thesis. 
2. Insight in the manifestation of cognitive flexibility and the accompanying learning process. The effect studies gave a detailed picture of student teachers' cognitive flexibility. Although student teachers demonstrated cognitive flexibility, the quality was diverging, in particular with regard to the use of concepts and the level of reasoning. 3. A positive indication for the development of a professional discourse.

The study showed that student teachers integrate concepts in their mutual communication about professional issues, indicating they are adopting a professional vocabulary.

4. Insight in CFT's potential for application in the context of a professional education and an empirically grounded contribution to CFT.

In this thesis CFT proved to be useful for problem analysis and led to a focus on the use of concepts. The design guidelines derived from CFT proved to be useful for designing an intervention but needed additional refining for a professional context. The main additions were:

- A specific pedagogical model with two central elements: video production in order to foster a relation with one's own professional practice and the consistent use of a conceptual framework in all learning tasks;

- Interaction between student teachers, teacher educators and teachers in order to foster social knowledge construction in meaningful contexts;

- Increasing complexity in the curriculum and the learning goals in order to build up cognitive flexibility;

- A conceptual framework of 'communication with parents' including relevant concepts from other knowledge domains that support professional practice.

5. Recommendations for teacher education practice.

This thesis shows that it is possible to establish a meaningful interaction between conceptual knowledge and professional practice based on CFT-principles in teacher education. However, this has far-reaching implications for the layout of curriculum and instruction. Recommendations concern the necessary adjustments to the curriculum and instruction and the use of video cases. 


\section{BIJ LAGEN}




\section{Bijlage A}

Verdeling van concepten over videocases in de onderwijsarrangementen

Bijlage bij hoofdstuk 3

\begin{tabular}{|c|c|c|c|c|c|c|c|c|}
\hline \multirow[b]{2}{*}{$\begin{array}{l}\text { Basisconcepten }^{\mathrm{a}} \\
\text { communicatiemodel }^{2}\end{array}$} & \multirow{2}{*}{$\begin{array}{l}\text { OA1 } \\
\text { VC1 }\end{array}$} & \multicolumn{3}{|c|}{ OA2 } & \multicolumn{2}{|c|}{ OA3 } & \multicolumn{2}{|c|}{ OA4 } \\
\hline & & VC1 & VC2 & VC3 & VC1 & VC2 & VC1 & $\mathrm{VC} 2^{\mathrm{b}}$ \\
\hline Expressieve boodschan & $x$ & & $x$ & & $x$ & & $x$ & 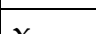 \\
\hline Relationele boodschap & $\mathrm{x}$ & & $\mathrm{x}$ & & $x$ & $\mathrm{x}$ & $\mathrm{x}$ & $\mathrm{x}$ \\
\hline Referentiële boodschap & $\mathrm{x}$ & & & & $x$ & & $x$ & $\mathrm{x}$ \\
\hline Appellerende boodschap & $x$ & & & & & & $x$ & \\
\hline Zender & $\mathrm{x}$ & & & & & & & \\
\hline Ontvanger & $x$ & & & & & & & \\
\hline $\begin{array}{l}\text { Communicatief doel } \\
\text { Informatief, persuasief, } \\
\text { instructief, motiverend, } \\
\text { affectief doel }\end{array}$ & $x$ & $x$ & $x$ & & $x$ & $\mathrm{x}$ & $x$ & $x$ \\
\hline Beleidsdoel & $x$ & $x$ & $\mathrm{x}$ & $x$ & & $\mathrm{x}$ & $x$ & \\
\hline Basisconcepten overig & & & & & & & & \\
\hline $\begin{array}{l}\text { Soort gesprek } \\
\text { Slechtnieuwsgesprek, } \\
\text { probleemverkennend, } \\
\text { probleemoplossend } \\
\text { gesprek; informatief, } \\
\text { instructief, motiverend, } \\
\text { persuasief, evaluatief } \\
\text { gesprek }\end{array}$ & & $x$ & & & $x$ & $\mathrm{x}$ & $x$ & \\
\hline $\begin{array}{l}\text { Status gesprek } \\
\text { (in)formeel gesprek }\end{array}$ & $x$ & & & & & & $x$ & \\
\hline $\begin{array}{l}\text { Gespreksvaardigheden } \\
\text { Diverse luister- en zender } \\
\text { vaardigheden, } \\
\text { regulerende } \\
\text { gespreksvaardigheden, } \\
\text { verbale en non-verbale } \\
\text { gespreksvaardigheden }\end{array}$ & & $x$ & & $\mathrm{x}$ & $x$ & $x$ & $x$ & \\
\hline $\begin{array}{l}\text { Fasering/opbouw } \\
\text { gesprek }\end{array}$ & & & & $x$ & & $\mathrm{x}$ & $x$ & $x$ \\
\hline $\begin{array}{l}\text { Interculturele } \\
\text { communicatie }\end{array}$ & & & & & $x$ & & & \\
\hline $\begin{array}{l}\text { Situatie } \\
\text { Gespreksopstelling, }\end{array}$ & & & & & & & $x$ & \\
\hline
\end{tabular}




\begin{tabular}{|c|c|c|c|c|c|c|c|}
\hline $\begin{array}{l}\text { randvoorwaarden, } \\
\text { fysieke omstandigheden }\end{array}$ & & & & & & & \\
\hline Communicatiebeleid & $x$ & & & $x$ & & & \\
\hline $\begin{array}{l}\text { Onderwijscontext } \\
\text { (factoren) } \\
\text { Loyaliteit, dynamische } \\
\text { driehoek, } \\
\text { ouderbetrokkenheid } \\
\text { verantwoordelijkheid, } \\
\text { deskundigheid, positie } \\
\text { stagiaire, wet- en } \\
\text { regelgeving }\end{array}$ & & $x$ & $x$ & $x$ & & $x$ & $x$ \\
\hline $\begin{array}{l}\text { Agressie } \\
\text { Instrumenteel, emotioneel }\end{array}$ & & & & $x$ & & & \\
\hline $\begin{array}{l}\text { Protocollen } \\
\text { machtsmisbruik } \\
\text { Protocollen i.v.m } \\
\text { vermoeden van } \\
\text { machtsmisbruik }\end{array}$ & & & & & & $x$ & \\
\hline $\begin{array}{l}\text { Integratievisie } \\
\text { Monocultureel, inter- } \\
\text { cultureel, transcultureel }\end{array}$ & & & & & $x$ & & \\
\hline
\end{tabular}

Noot. $\mathrm{OA}=$ onderwijsarrangement; $\mathrm{VC}=$ videocasus

aDe basisconcepten zijn opgenomen in de digitale conceptuele structuur. Sommige bevatten subconcepten waarvan hier een niet-uitputtende opsomming is gegeven. ${ }^{b}$ Deze casus 2 verwijst niet naar een videocasus, maar naar een authentieke gespreksituatie met ouders in de basisschool, waarvan studenten videobeelden maken. 


\section{Bijlage B \\ Het instructieontwerp geconcretiseerd: Een uitgewerkt voorbeeld}

Bijlage bij hoofdstuk 3

\section{Introductie videocasus en bijbehorende issues}

Onderwijsarrangement 2 begint met een plenair college waarin teruggeblikt wordt op arrangement 1 dat een jaar geleden plaatsvond. De docent brengt het communicatiemodel in herinnering, licht de conceptuele structuur toe en introduceert drie videocases. Studenten kiezen op grond van hun persoonlijke leerpunten en interesses één van de drie videocases uit om zich in te verdiepen. Figuur B1 laat een beeld zien uit de videocasus 'Ouder de klas uit'.

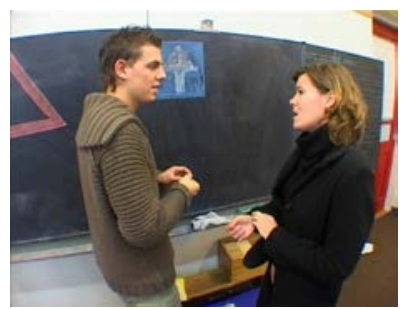

Figuur B1 'Ouder de klas uit', een videocasus in onderwijsarrangement 2.

Een ouder spreekt de stagiaire/leerkracht Wouter op een onverwachts moment aan.

In de videocasus 'Ouder de klas uit' staat een dilemma uit de beroepspraktijk van het primair onderwijs centraal, namelijk 'Hoe om te gaan met ouders die een leerkracht onverwachts onder schooltijd met een probleem confronteren'? Om te laten zien dat de situatie niet per se één juiste aanpak kent, worden in de videocasus twee handelingsalternatieven getoond. In de videocasus figureert een stagiaire in de rol van leerkracht om de identificatie van de student met de situatie te vergemakkelijken. De getoonde situatie bestaat uit twee hoofdscenes: in de eerste scene vraagt de directeur of de stagiaire Wouter de hele middag zelfstandig wil lesgeven, want de verantwoordelijke mentor is ziek naar huis gegaan en de klas zit nu onverwachts zonder leerkracht. In de tweede scene is Wouter druk bezig met de voorbereiding van zijn les. Onverwachts wordt hij daarin gestoord door binnenkomst van een ouder die een lang en emotioneel verhaal begint over haar dochter. De kwestie is nu: Hoe reageert Wouter op deze ouder? Handelingsalternatief 1: Wouter luistert empathisch naar het verhaal en denkt mee over mogelijke oplossing. Zijn les is niet voorbereid. Handelingsalternatief 2: Wouter onderbreekt de ouder en verwijst haar naar de directeur om een oplossing te zoeken voor haar probleem. Zijn lesvoorbereiding is klaar.

Aan deze praktijksituatie zijn verscheidene issues met betrekking tot communicatie verbonden, waarbij te denken valt aan:

- Wat is een bevredigende reactie voor de ouder en voor de leerkracht? Wat verwacht de ouder?

- Wat behoort tot de verantwoordelijkheid en deskundigheid van de leerkracht? Welke prioriteiten stelt de leerkracht? Hoe schat de leerkracht de urgentie van het probleem in? 
- Hoe is de relatie tussen leerkracht en ouder en hoe belangrijk vindt de leerkracht deze relatie?

De afwegingen die leiden tot de keuze voor een bepaald gedrag worden beïnvloed door diverse contextfactoren, bijvoorbeeld de cultuur binnen de school, het communicatiebeleid, eerdere ervaringen tussen de ouder en de leerkracht, de relatie tussen ouder-leerling-leerkracht, de positie van een stagiaire en opvattingen over de verantwoordelijkheid van ouder en leerkracht. Om een betekenisvolle interpretatie van deze casus te kunnen geven- en om te motiveren welke reactie de student zelf passend zou vinden - is het van belang dergelijke overwegingen expliciet te maken.

\section{Leertaak, feedback en beoordeling}

De leertaak is opgebouwd volgens het didactisch model en kent voor de student vier onderdelen; de laatste fase van het expliciteren valt voor hen samen met de toetsing. De verschillende onderdelen van de leertaak komen nu achtereenvolgend aan bod. De introductiefase van de coöperatieve leertaak leidt studenten naar het expliciteren van de eigen opvattingen en het confronteren met andere opvattingen. Een deel van de leertaak bij de videocasus 'Ouder de klas uit' is te zien in Figuur B2.

\section{A. Video bekijken + eerste reacties inventariseren}

1. Formuleer eigen mening en groepsmening

- Bekijk individueel de video met beide situaties: Ouder de klas uit 1 en Ouder de klas uit 2.

$\underline{\text { www.fontys. } \mathrm{nl} / \text { colevi/ }}$

Kies producten $>$ Kies video's primair onderwiis

Als jij in Wouters schoenen had gestaan bij het gesprek met de ouder, voor welke van de twee oplossingen had je dan gekozen? Zie je misschien een andere oplossing?

Noteer je bevindingen.

- Bespreek met je medestudenten de argumenten voor oplossing 1, oplossing 2 en mogelijke andere oplossingen.

Noteer deze argumenten.

2. Sterkte-zwakte analyse van gesprek in beide situaties

- Analyseer beide situaties. Bespreek per situatie het volgende:

Wat vonden jullie dat Wouter goed deed in dit gesprek en wat is voor verbetering vatbaar? Over welke aspecten zijn jullie het eens? Over welke oneens?

Maak gezamenlijk een lijst met argumenten waarover jullie het eens zijn en een lijst met punten waarop jullie van mening verschillen.

Figuur B2 Deel van leertaak: introductie

Het tweede onderdeel van de leertaak, de conceptuele verdieping, bevat opdrachten voor analyse. De opdrachten hebben betrekking op het in kaart brengen van de communicatieve en beleidsdoelen van beide gesprekspartners, op de contextfactoren die deze specifieke situatie beïnvloeden en op het betrekkingsaspect van de 
communicatie. In deze opdrachten wordt een aantal centrale concepten herhaald en verdiept (communicatief doel, beleidsdoel, expressieve boodschap, relationele boodschap) en een aantal specifieke concepten aangeleerd (contextfactoren, gespreksvaardigheden). De contextfactoren zijn divers van aard en bevatten soms concepten uit andere domeinen dan de communicatiekunde, bijvoorbeeld deskundigheid/verantwoordelijkheid en loyaliteit. De opdracht over het betrekkingsaspect van communicatie is opgenomen in Figuur B3.

\section{B. Theoretisch verdiepen}

\section{Expressieve en relationele boodschap}

Een gesprek kun je analyseren met behulp van een communicatiemodel. Wij maken gebruik van het onderstaande model. Met behulp van de expressieve en relationele boodschap kun je de verhouding tussen de gesprekspartners en het zelfbeeld van de gesprekspartners beschrijven.

Appellerend: het doel

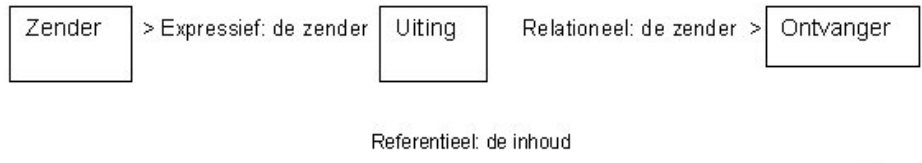

(Uit: Steehouder, M. e.a. (1999). Leren com municeren. Handhoek woor m ondelinge en schrifelghe com munic atie. $4^{\circ}$ gehee herziene druk. Groningen: Wotters-Noordhoff,

- Analyseer beide gesprekssituaties op de volgende manier: Verplaats je eerst in het perspectief van de ouder, mevrouw Bennink.

Beschrijf welke expressieve en relationele boodschap zij uitzendt en waaraan je dat merkt. Benoem daarbij haar verbale en non-verbale uitingen. Welk effect heeft haar expressieve en relationele boodschap op Wouter?

Verplaats je vervolgens in het perspectief van Wouter. Doe voor hem hetzelfde.

- Noteer je eigen beargumenteerde mening: welke expressieve en relationele boodschap zou jij in deze situatie willen uitzenden, als je in Wouters plaats stond? Hoe doe je dat, verbaal en non-verbaal?

Informatie en literatuurverwijzingen over communicatiemodel:

www.edith.nl/Sherpa pro/ > Vakgebied Communicatie > Communicatiemodel

Figuur B3 Deel van leertaak: conceptuele verdieping

In het derde onderdeel van de leertaak worden de voorgaande opdrachten geïntegreerd doordat studenten elkaar informeren. Door uitwisseling komen ze tot gezamenlijke verbetervoorstellen voor het communicatieve gedrag van de leerkracht. De opdracht daartoe is te zien in Figuur B4. 


\section{Bij elkaar brengen}

Werk gezamenlijk aan het volgende onderdeel. Neem je uitgewerkte opdrachten mee. Jullie gaan verbeteringen en veranderingen in het communicatieve gedrag van de leerkracht beschrijven en beargumenteren.

- Wissel met elkaar uit waarin je je hebt verdiept.

Toon eventueel ter verheldering de videofragmenten waarop je je baseert.

Geef daarbij de anderen een samenvatting van de theorie die jij hebt bestudeerd.

- Besluit gezamenlijk welke oplossing (ouder doorverwijzen, ouder helpen of alternatief) jullie het beste vinden. Bekijk het gesprek opnieuw op de video.

Formuleer hoe jullie dit gesprek idealiter zouden willen laten verlopen. Focus je op het communicatieve gedrag van de leerkracht. Noteer dus mogelijke verbeteringen in het communicatieve gedrag van de leerkracht.

Baseer jullie 'ideale gesprek' op de theoretische verdieping d.w.z. maak gebruik van de kennis die je bij opdracht B hebt opgedaan.

Figuur B4 Deel van leertaak: integratie

De uitgewerkte opdrachten van de eerste drie fasen worden in een groepsconsultatie met de docent besproken en van feedback voorzien. Na deze sessie gaan studenten hun eigen videobeelden maken: zij spelen de situatie van Wouter na en tonen het professionele gedrag dat zij het meest passend vinden. Gespreksvaardigheden worden zo in een veilige omgeving geoefend. Deze videobeelden worden opgenomen in een PowerPointpresentatie en van een toelichting voorzien. Het vierde onderdeel van de leertaak bevat praktische aanwijzingen voor het maken van de videobeelden. Figuur B5 bevat de opdracht voor de toelichting bij de videobeelden.

\section{Toepassen}

- Selecteer videofragmenten waarin de leerkracht goede communicatieve vaardigheid toont. Neem van elk groepslid minimaal één fragment op in de presentatie.

Zet de fragmenten in een PowerPoint-presentatie. Max. 6 minuten.

- Benoem waarom jullie dit een goed fragment vinden. Voeg dat toe aan je Powerpointpresentatie. Maak bij je toelichting gebruik van de theoretische begrippen uit onderdeel B en C. Gebruik dus professionele terminologie.

- Benoem sterke en zwakke kanten van jullie eigen communicatief gedrag in de basisschool (op basis van je stage-ervaring en eventueel andere ervaringen) met behulp van professionele termen. Duur gehele presentatie, inclusief video: 15 minuten.

Figuur B5 Deel van leertaak: toepassing 
Ten slotte presenteren studenten hun videocasus aan medestudenten in een plenaire bijeenkomst en expliciteren zij wat ze hebben geleerd. Sommige medestudenten hebben dezelfde casus bestudeerd, andere hebben een andere casus gekozen. Tijdens deze sessie vindt uitwisseling tussen de studenten plaats over de interpretatie van de situatie en over de gebruikte concepten. De toehorende student stelt vragen en heeft, met de docent, een stem in de beoordeling van de presentatie. De

beoordelingscriteria betreffen twee onderdelen: het communicatieve handelen en de verantwoording daarvan. De criteria in Tabel B1 geven hiervan een indruk.

Tabel B1 Deel van beoordelingscriteria

\begin{tabular}{|c|c|c|}
\hline Inhoud & Criteria & $\begin{array}{l}\text { Beoordeling } \\
\text { V/O }\end{array}$ \\
\hline \multicolumn{3}{|c|}{ Handelen In de videobeelden is het volgende te zien: } \\
\hline Gespreksvaardigheden & $\begin{array}{l}\text { Leerkracht hanteert effectief minimaal } 4 \text { verbale } \\
\text { en non-verbale zender- en luistervaardigheden }\end{array}$ & \\
\hline Effectiviteit & $\begin{array}{l}\text { Leerkracht bereikt communicatief doel op } \\
\text { respectvolle wijze }\end{array}$ & \\
\hline \multicolumn{3}{|c|}{ Verantwoording In de toelichting worden de volgende begrippen gebruikt: } \\
\hline $\begin{array}{l}\text { Communicatieve } \\
\text { situatie }\end{array}$ & $\begin{array}{l}\text { Het communicatieve 'probleem' wordt vanuit } \\
\text { diverse perspectieven (leerkracht, ouder, school) } \\
\text { belicht. }\end{array}$ & \\
\hline $\begin{array}{l}\text { Communicatief doel } \\
\text { leerkracht en ouder }\end{array}$ & $\begin{array}{l}\text { Juist gebruik van de begrippen informatief, } \\
\text { persuasief, motiverend, instructief, affectief. }\end{array}$ & \\
\hline $\begin{array}{l}\text { Onderwijscontext/ } \\
\text { Contextfactoren }\end{array}$ & $\begin{array}{l}\text { Minimaal drie relevante contextfactoren worden } \\
\text { benoemd en toegelicht: deskundigheid/ } \\
\text { verantwoordelijkheid, communicatiebeleid, } \\
\text { positie stagiaire, loyaliteit, ouderbetrokkenheid. }\end{array}$ & \\
\hline Expressieve boodschap & $\begin{array}{l}\text { Het begrip wordt juist gebruikt en onderbouwd } \\
\text { met voorbeelden van verbaal en non-verbaal } \\
\text { gedrag. }\end{array}$ & \\
\hline
\end{tabular}




\section{Bijlage C \\ Interviewschema studenten}

Bijlage bij hoofdstuk 4

\section{A. Verwachtingen}

1. Wat verwachtte je van tevoren van deze onderwijseenheid?

2. In hoeverre zijn je verwachtingen uitgekomen?

Eventuele redenen voor verschil?

\section{B. De inhoud: leeropbrengst en motivatie}

1. Welke casus heb je gekozen?

o Ouder de klas uit

o Inschakelen ouder

o Agressieve ouder

2. Waarom koos je die casus?

3. Vind je dat je iets hebt geleerd van deze casus? Zo ja, wat? Zo nee, hoe kwam dat?

Doorvraag: In hoeverre kwam dit overeen met je verwachtingen?

4. Verbetersuggesties voor deze casus?

\section{De opzet}

De opzet van deze GOE-bijeenkomsten was: introductie, consultatie, eindpresentatie.

1. Wat vond je van deze opzet?

2. In deze opzet moest je veel zelf doen en was er relatief weinig contact met docent.

Hoe vond je dat?

3. Verbetersuggesties voor opzet?

\section{Werkwijze}

De werkwijze bestond uit: groepsgewijs werken, zelfstandig theoretisch verdiepen en een presentatie maken.

1. Hoe ging de samenwerking in jullie groep?

- Taakverdeling

- Inbreng

Doorvraag: Heb je iets aan de anderen gehad?

2. Op welke manier hebben jullie je theoretisch verdiept?

- gebruik concept map

- gebruik literatuur

- andere bronnen

3. Hoe vond je het om een presentatie te maken met videobeelden?

- Hoe te werk gegaan?

- Wat heb je daarvan geleerd? 
4. Hoe vond je het om een presentatie te houden, die van anderen bij te wonen en mee te beoordelen?

Doorvragen op beoordeling:

Heb je voorbeelden van anderen gezien die je heel goed vond, of juist slecht?

Wat leer je eventueel tijdens presentaties, hoe gaat dat?

Beoordeling eerlijk/oneerlijk?

5. Verbetersuggesties voor werkwijze?

\section{E. Materialen}

1. Bij deze onderwijseenheid heb je gebruik gemaakt van verschillende materialen. Wat vind je van de duidelijkheid, toegankelijkheid en het niveau van die materialen? (NB. Inter- en intranet)

- Opdracht

- Videocases

- Concept map

- Literatuur

- Beoordelingscriteria (duidelijkheid criteria, niveau, cesuur)

2. Verbetersuggesties materialen?

\section{F. Algemeen}

1. Hoe vond je deze opdracht? (inhoud, werkwijze)

Doorvragen naar argumentatie (bijv. nuttig voor ..., niet leuk vanwege ...)

2. Heb je eerder in de opleiding iets over dit onderwerp gehad?

Doorvragen: Zo ja, zie je verband? Zo nee, helpen herinneren aan BS2.

3. Wat zou je nog willen leren op dit terrein in volgende fasen?

4. Overige opmerkingen/toevoegingen? 


\section{Bijlage D \\ Interviewschema docenten}

Bijlage bij hoofdstuk 4

\section{A. Verwachtingen}

1. Wat waren je verwachtingen vooraf over deze onderwijseenheid?

2. In hoeverre zijn je verwachtingen uitgekomen?

Eventueel redenen voor verschil?

\section{B. De materialen}

1. Wat vind je van de inhoud van de concept map en de ict-kant ervan via intranet?

2. Wat vind je van de inhoud van de videocases?

3. Wat vind je van de opdrachten?

- Duidelijkheid

- Niveau

- Motiverend karakter

4. Wat vind je van de koppeling van theorie en praktijk d.w.z. de koppeling tussen concepten en eigen handelen tonen in eigen videobeelden?

5. Verbetersuggesties?

C. De opbrengst

1. Wat denk je dat studenten hebben geleerd op conceptueel en praktisch niveau?

\section{Beoordeling}

1. Hoe ging de beoordeling in $z^{\prime} n$ werk?

- studentparticipatie

2. Hoe vond je het beoordelingsformulier?

- Duidelijkheid criteria

- Niveau

- Cesuur

3. Verbetersuggesties?

E. Grote lijn in opzet onderwijsarrangementen voor Communiceren

1. In hoeverre vind jij dit een vorm van competentiegericht onderwijs?

2. Hoe kijk je aan tegen de opbouw van dit onderwerp in het curriculum?

\section{F. Algemene indruk}

1. Wat is jouw algehele indruk van deze opdracht?

- Materialen

- Werkwijze

- Inhoud/opbrengst

2. Overige opmerkingen/toevoegingen? 


\section{Bijlage E}

Voorbeelden van categorieën bij instrument data-analyse in studie 2a

Bijlage bij hoofdstuk 6

\begin{tabular}{|c|c|c|}
\hline Niveau 1 & Voorbeeld & $\begin{array}{l}\text { Toelichting aard en niveau } \\
\text { concepten }\end{array}$ \\
\hline A1 & $\begin{array}{l}\text { B. Het communicatief doel van de leerkracht uh } \\
\text {... nou je hebt verschillende doelen. Informatief, } \\
\text { kan zijn dat uh ... de leerkracht vertelt vanne.. } \\
\text { dat hij een stagiaire is, dat hij eigenlijk uh de } \\
\text { moeder niet kan helpen, wel wil helpen. Maar } \\
\text { hij zegt gelijk vannne ... Ik weet er eigenlijk } \\
\text { niet zoveel van. Ik weet wel dat ze gaan } \\
\text { schoolzwemmen, maar hoe dat dan geregeld } \\
\text { wordt ... alleen dat ze naar groep } 3 \text { ging uh. } \\
\text { Verder kon hij er niet veel over vertellen. Maar } \\
\text { hij geeft wel gelijk duidelijk weer in welke } \\
\text { positie hij staat. Persuasief uh ... overtuigen. } \\
\text { Dus uh, de stagiaire overtuigt de moeder er wel } \\
\text { van dat ze goede bedoelingen heeft om samen } \\
\text { tot een oplossing te komen. En uh .. motiverend. } \\
\text { Ze laat de moeder dus ook heel veel uh aan het } \\
\text { gesprek uh ja betrokken zeg maar. Ze laat } \\
\text { duidelijk de stem van de moeder ook gelden; } \\
\text { dat die ook belangrijk is en dat niet alleen de } \\
\text { leerkracht beslist van dit gaat gebeuren. Enne .. } \\
\text { ze leeft dus ook heel erg mee met de moeder. } \\
\text { Dat kun je duidelijk zien, dat zij zich ook goed } \\
\text { kan verplaatsen. Uh ... instructief. Wat is dat } \\
\text { nou, instructief? [buigt zich naar medestudent, } \\
\text { kijkt op papier]. Oh ja, de leerkracht vertelt aan } \\
\text { de ouder precies wat er gaat gebeuren. Eerst } \\
\text { wordt er verteld dat ze op gaan bellen, dat ze } \\
\text { de echte juffrouw op gaan bellen, dat de } \\
\text { moeder dan verder hoort wat er gebeurt. Maar } \\
\text { later komt juf Wilma binnen enne dan wordt } \\
\text { het weer heel anders, maar het komt goed } \\
\text { terecht. Nou, affectief ... dat is uh ... } \\
\text { L. Inleven } \\
\text { B Ja, affectief is zorgen dat het gesprek uh de } \\
\text { sfeer van het gesprek is gemoedelijk. De } \\
\text { moeder aan het woord, de leraar aan het } \\
\text { woord, ze laten elkaar rustig uitpraten. Er is } \\
\text { een goede communicatie aanwezig, de sfeer is } \\
\text { gewoon erg prettig om met elkaar te } \\
\text { communiceren. } \\
\text { (uit geval 4) }\end{array}$ & $\begin{array}{l}\text { Aard } \\
\text { Het gedrag van de leerkracht- } \\
\text { stagiaire wordt voornamelijk } \\
\text { beschreven (en impliciet alleen } \\
\text { gemotiveerd bij informatief doel } \\
\text { met de zin 'Maar hij geeft wel } \\
\text { gelijk duidelijk weer in welke } \\
\text { positie hij staat'). } \\
\text { Niveau } \\
\text { Zes concepten worden gebruikt. } \\
\text { Hiervan is } 1 \text { begrip juist } \\
\text { geïnterpreteerd (persuasief } \\
\text { doel) en zijn } 4 \text { concepten deels } \\
\text { of geheel onjuist geïnterpreteerd } \\
\text { (het informatieve, motiverende, } \\
\text { instructieve en affectieve doel). } \\
\text { Het opnoemen van } 5 \\
\text { verschillende communicatieve } \\
\text { doelen is niet passend in de } \\
\text { analyse van dit fragment; er is } \\
\text { geen selectie gemaakt en daaruit } \\
\text { blijkt dat de functie van het } \\
\text { concept 'communicatief doel' } \\
\text { niet goed is begrepen. Het } \\
\text { inadequate begrip van de } \\
\text { concepten leidt ertoe dat de } \\
\text { gehele beschrijving/analyse } \\
\text { grotendeels onjuist is. Daarom: } \\
\text { niveau } 1\end{array}$ \\
\hline C1 & $\begin{array}{l}\text { Jo. In het derde stukje is het dus afspraken } \\
\text { maken. Je wijst die moeder niet af, je laat haar } \\
\text { er wel bij, omdat je wel weet dat zij dit heel erg }\end{array}$ & $\begin{array}{l}\text { Aard } \\
\text { In eerste instantie wordt door Jo } \\
\text { het leerkrachtgedrag al }\end{array}$ \\
\hline
\end{tabular}




\begin{tabular}{|c|c|}
\hline $\begin{array}{l}\text { leuk vindt. Maar je maakt daarvoor gewoon } \\
\text { duidelijke afspraken, het is voor jou een } \\
\text { belangrijke opdracht, dat zij ook weet waarvoor } \\
\text { het is, dat het niet zomaar iets is. Je maakt } \\
\text { gewoon duidelijke afspraken wat je wel wil en } \\
\text { wat je niet wil. En we hebben er dus voor } \\
\text { gekozen om er nog een ouder bij te vragen. Dus } \\
\text { misschien dat ze met z'n tweeën, samen, wat } \\
\text { meer sturing hebben daarvoor. } \\
\text { Je. We wouden ja eerst eigenlijk, we hadden } \\
\text { eerst eigenlijk gedacht om met een leugentje } \\
\text { voor bestwil haar af te wijzen, maar ... ja ... dat } \\
\text { hadden we toch niet gedaan, want we dachten } \\
\text {... we waren bang dat ze via via .. stel, het is } \\
\text { een echte situatie ... dat ze er dan achterkomt. } \\
\text { En in een echte situatie, hadden we gezegd, } \\
\text { zouden we dat niet aandurven, dus daarom } \\
\text { deden we dat nu ook niet. } \\
\text { J. En sowieso denk ik ook dat je als school toch } \\
\text { wil uitstralen dat je elke hulp kan gebruiken. } \\
\text { En elke ouder ... je wil gewoon als school } \\
\text { laagdrempelig zijn ... ik bedoel, elke ouder } \\
\text { moet zo binnen kunnen lopen en wat kunnen } \\
\text { vragen. Maar ook dat je gewoon kunt } \\
\text { vertrouwen op hun hulp. En ik denk dat als je } \\
\text { iemand toch uh afwijst ... als dat dan misschien } \\
\text { rond zou gaan, dat zij dan, wat Jenny ook zei, } \\
\text { er toch achter zou komen, dat het toch niet } \\
\text { helemaal zo is als dat jij gezegd hebt, dat je } \\
\text { daar dan toch ook voor jezelf een probleem } \\
\text { mee krijgt en dat ouders misschien helemaal } \\
\text { niet meer willen helpen. Ik denk dat je toch als } \\
\text { doel moet hebben dat je beide partijen tevreden } \\
\text { houdt en door op deze manier de ouder te } \\
\text { informeren zo van wat het geval is, dat } \\
\text { [onverstaanbaar] wat jouw situatie op dat } \\
\text { moment is. Dat het voor de Pabo is en voor jou } \\
\text { een belangrijk bezoek. En uh, ja, zij weet dan } \\
\text { ook in principe wat er van haar verwacht } \\
\text { wordt dus je speelt wel een beetje in op de } \\
\text { situatie. } \\
\text { (uit geval } 5 \text { ) }\end{array}$ & $\begin{array}{l}\text { gemotiveerd. Uitgelegd wordt } \\
\text { waarom afspraken worden } \\
\text { gemaakt en waarom de ouder } \\
\text { niet wordt afgewezen. In } \\
\text { tweede instantie wordt door Je } \\
\text { en J. dieper ingegaan op de } \\
\text { achtergrond voor deze keuze en } \\
\text { worden de (ethische) } \\
\text { overwegingen naar voren } \\
\text { gebracht die ten grondslag } \\
\text { hebben gelegen aan de keuze } \\
\text { voor het niet afwijzen van de } \\
\text { ouder. Het leerkrachtgedrag } \\
\text { wordt hiermee nogmaals, } \\
\text { diepgaander, verklaard. } \\
\text { Niveau } \\
\text { In het fragment worden geen } \\
\text { concepten gebruikt. } \\
\text { Daarom: niveau } 1 .\end{array}$ \\
\hline
\end{tabular}

\begin{tabular}{|l|l|l|}
\hline Niveau 2 & Voorbeeld & $\begin{array}{l}\text { Toelichting aard en niveau } \\
\text { concepten }\end{array}$ \\
\hline A2 & $\begin{array}{l}\text { A. Het 7-stappenplan. Nou, benader een klant } \\
\text { met een open houding, dat is dus de moeder. De } \\
\text { stagiaire legt haar spullen aan de kant, } \\
\text { waarmee ze aan het voorbereiden is. Ze is } \\
\text { eigenlijk wel een beetje overrompeld, maar } \\
\text { toch staat ze echt open voor de moeder. Maar } \\
\text { ze heeft wel zoiets van 'Ik haal de juf erbij, }\end{array}$ & $\begin{array}{l}\text { Aard } \\
\text { Het handelen van de stagiaire- } \\
\text { leerkracht in de getoonde } \\
\text { videobeelden wordt beschreven } \\
\text { m.b.v. het 7-stappenplan en de } \\
\text { daaraan verbonden } \\
\text { gespreksvaardigheden. }\end{array}$ \\
\hline
\end{tabular}




\begin{tabular}{|c|c|c|}
\hline & $\begin{array}{l}\text { omdat ze zelf niet bij de gymles was. Ze heeft } \\
\text { wel een open houding en ze biedt ook drinken } \\
\text { aan, of de moeder iets drinken wil, enne, ga } \\
\text { zitten. Dan komt dus de juf. Die laat dus de } \\
\text { moeder haar boosheid uiten. Ze kan } 2 \text { x zelfs } \\
\text { haar verhaal vertellen: eerst als ze nog } \\
\text { helemaal agressief is en daarna als ze wat } \\
\text { rustiger is. En dan vat ze dus samen de drie } \\
\text { punten waar ze dus eigenlijk mee zit. Stap 4, } \\
\text { dan zeg ik dus dat ik begrip toon, dat het } \\
\text { gewoon mis is gegaan en dat er } \\
\text { miscommunicatie is. En dat het me heel erg } \\
\text { spijt enzo en of ik het haar uit mag leggen. } \\
\text { Nou, bij } 5 \text { geef ik dus informatie op alle drie de } \\
\text { punten van de moeder. Dus waarom de stagiaire } \\
\text { niet mee is geweest en waarom hij een } \\
\text { onvoldoende heeft en dat er dus nog wel een } \\
\text { kans komt. En bij stap } 6 \text {, nou, dan is de oplossing } \\
\text { dat iedereen nog wel een tweede kans krijgt, } \\
\text { maar dat het dus verkeerd is begrepen. En dat } \\
\text { ik dan zelf nog even met het kind praat de } \\
\text { volgende dag om voortaan zulke } \\
\text { misverstanden te voorkomen, omdat het } \\
\text { gewoon erg vervelend is. En stap } 7, \text { positief } \\
\text { afsluiten, dat ik de moeder toch nog even } \\
\text { bedank dat ze toch wat rustiger is geworden en } \\
\text { dat ik blij ben dat ze bij me is gekomen en dat } \\
\text { het vervelend is als er zulke problemen tussen ouder } \\
\text { en leerkracht in blijven staan. Voor de relatie is dat } \\
\text { natuurlijk vervelend. De moeder gaat dan ook } \\
\text { met een positief gevoel, naar mijn gevoel, weer } \\
\text { weg, dus het is positief afgesloten. } \\
\text { (uit geval 6) }\end{array}$ & $\begin{array}{l}\text { Niveau } \\
\text { Zeven concepten, } \\
\text { gespreksvaardigheden, worden } \\
\text { genoemd: open houding, } \\
\text { boosheid laten uiten, } \\
\text { samenvatten, begrip tonen, } \\
\text { informatie geven, oplossing } \\
\text { bieden, positief afsluiten. } \\
\text { De concepten zijn juist } \\
\text { geïnterpreteerd en verbonden } \\
\text { aan concrete voorbeelden van } \\
\text { eigen handelen. De stappen } \\
\text { worden achter elkaar } \\
\text { opgesomd, zonder dat er een } \\
\text { verband tussen de stappen } \\
\text { wordt aangegeven. } \\
\text { Daarom: niveau } 2\end{array}$ \\
\hline $\mathrm{C} 2$ & $\begin{array}{l}\text { De appellerende boodschap van Jennifer is } \\
\text { eigenlijk het aanzetten of motiveren tot een } \\
\text { andere activiteit. Die hulp hebben we dus } \\
\text { eigenlijk niet nodig, maar er zijn, wat } \\
\text { [onverstaanbaar] ook al vertelde, wel heel veel } \\
\text { andere dingen waar we hulp van ouders wel } \\
\text { bij nodig hebben. Dus Jennifer probeert in dit } \\
\text { geval de ouder te motiveren om een andere } \\
\text { activiteit te doen zodat ze zich toch nog een } \\
\text { beetje gewaardeerd voelt omdat ze ja, eigenlijk } \\
\text { toch wordt afgewezen. De expressieve boodschap, } \\
\text { ik vond hem bij Jennifer best wel heel erg } \\
\text { zeker. Jennifer komt heel ... ze straalt wel } \\
\text { overtuigingskracht uit en lijkt wel heel zeker } \\
\text { van haar zaak. Ik vind dat je een beetje verschil } \\
\text { kan zien met Carien, die komt toch iets meer } \\
\text { onzeker over en Jennifer is wat zekerder in dit } \\
\text { geval. De relationele boodschap: Jennifer weet dat } \\
\text { de ouder heel hulpvaardig is, dat ze heel } \\
\text { enthousiast is om haar hulp aan te bieden, om } \\
\text { te helpen bij allerlei dingen en tegelijkertijd }\end{array}$ & $\begin{array}{l}\text { Aard } \\
\text { In dit fragment wordt een } \\
\text { motivatie gegeven voor de } \\
\text { inhoud van de appellerende en } \\
\text { relationele boodschap van de } \\
\text { leerkracht. Het tussendeel over } \\
\text { de expressieve boodschap is } \\
\text { vergelijkend van aard. } \\
\text { Niveau } \\
\text { Vier concepten zijn gebruikt: } \\
\text { appellerende boodschap, } \\
\text { motiveren, expressieve } \\
\text { boodschap, relationele } \\
\text { boodschap. } \\
\text { De concepten zijn juist } \\
\text { geïnterpreteerd. } \\
\text { In de verklaring van het gedrag } \\
\text { worden zinvolle aspecten met } \\
\text { elkaar in verband gebracht. Met } \\
\text { name de inhoudelijke relatie } \\
\text { tussen de appellerende en }\end{array}$ \\
\hline
\end{tabular}




\begin{tabular}{|l|l|l|}
\hline weet ze ook dat die ouder het heel jammer & relationele boodschap is \\
vindt. Dus ze probeert voorzichtig een beetje de & adequaat. De concepten worden \\
boodschap te geven, dus dat ze de ouder niet & echter niet in een zichtbaar \\
wil teleurstellen, om haar dus af te wijzen, & samenhangend verband \\
maar dat ze wel een andere opdracht, een & geplaatst en het verband met de \\
andere activiteit kan begeleiden. Dat hangt een & expressieve boodschap is \\
beetje met elkaar samen. & onduidelijk. \\
(uit geval 2) & Daarom: niveau 2 \\
\hline
\end{tabular}

\begin{tabular}{|c|c|c|}
\hline Niveau 3 & \begin{tabular}{|l} 
Voorbeeld \\
\end{tabular} & $\begin{array}{l}\text { Toelichting aard en niveau } \\
\text { concepten }\end{array}$ \\
\hline A3 & $\begin{array}{l}\text { G. En dan nog even kort naar de } \\
\text { onderwijscontext. In het filmpje zag je loyaliteit } \\
\text { terug. De leerkracht houdt zich namelijk aan het } \\
\text { beleidsdoel van de school, dus hij is er trouw aan. } \\
\text { Deskundigheid: de leerkrachten weten hoe ze } \\
\text { moeten handelen, ze kennen het stappenplan, } \\
\text { positief afsluiten, tussendoor begrip tonen et cetera. } \\
\text { En verantwoordelijkheid voor een veilige omgeving } \\
\text { voor de leerlingen. Dus een aparte ruimte } \\
\text { zoeken. En natuurlijk zijn eigen veiligheid door } \\
\text { even iemand op de hoogte te stellen. } \\
\text { (uit geval 3) }\end{array}$ & $\begin{array}{l}\text { Aard } \\
\text { Beschreven wordt hoe bepaalde } \\
\text { contextfactoren herkenbaar zijn } \\
\text { in het gedrag van de leerkracht. } \\
\text { Niveau } \\
\text { Acht concepten worden } \\
\text { gebruikt. In een zeer compact } \\
\text { fragment worden (onder } \\
\text { tijdsdruk) diverse concepten } \\
\text { met elkaar in verband gebracht. } \\
\text { Er is niet alleen sprake van een } \\
\text { opsomming, ook verbanden } \\
\text { worden gelegd. Bijvoorbeeld } \\
\text { het verband tussen loyaliteit en } \\
\text { beleidsdoel, tussen } \\
\text { deskundigheid en positief } \\
\text { afsluiten en begrip tonen. } \\
\text { Daarom: niveau } 3\end{array}$ \\
\hline $\mathrm{C} 3$ & $\begin{array}{l}\text { Het communicatiedoel, nou we hebben twee } \\
\text { communicatiedoelen eigenlijk, informatief en } \\
\text { motiverend. Informatief was dat je aan het begin } \\
\text { al uitlegde van 'Nou, ik ben stagiaire en ik heb } \\
\text { nou geen tijd [onverstaanbaar]. Dat je bezig } \\
\text { bent met voorbereiding en dat je eigenlijk heel } \\
\text { graag wilt helpen, maar dat je heel erg druk } \\
\text { bent'. En ons motiverende communicatiedoel } \\
\text { was dan 'aanzetten tot een gesprek na } \\
\text { schooltijd'. Dus duidelijk aangeven van ik heb } \\
\text { nu geen tijd, maar ik zou ook graag willen } \\
\text { weten wat er precies gebeurd is. Dus dat ik ook } \\
\text { met de kinderen in gesprek kan gaan en dan } \\
\text { samen tot een goede oplossing komen. En het } \\
\text { beleidsdoel was dan ook de ruzie uitpraten, dus } \\
\text { een oplossing vinden voor dat probleem. } \\
\text { [Videofragment } 2 \text { wordt vertoond] } \\
\text { (uit geval 1) }\end{array}$ & $\begin{array}{l}\text { Aard } \\
\text { Het hele fragment heeft een } \\
\text { verklarend karakter: verklaard } \\
\text { wordt het leerkrachtgedrag in } \\
\text { de getoonde videobeelden. De } \\
\text { soort redenering is 'Ons doel } \\
\text { was X en daarom deed ik Y'. } \\
\text { Niveau } \\
\text { Het communicatieve gedrag } \\
\text { wordt verklaard m.b.v. } 4 \\
\text { concepten: communicatief doel, } \\
\text { informatief, motiverend, } \\
\text { beleidsdoel. } \\
\text { Deze concepten zijn adequaat } \\
\text { geïnterpreteerd en worden in } \\
\text { een redenering opgenomen. } \\
\text { Het verband tussen de } \\
\text { communicatieve doelen } \\
\text { onderling is duidelijk gemaakt, } \\
\text { maar ook het verband met het } \\
\text { beleidsdoel. Dit is zichtbaar aan } \\
\text { woorden zoals dus, dan, dan ook. } \\
\text { Daarom: niveau } 3\end{array}$ \\
\hline
\end{tabular}




\section{Bijlage F \\ Opdracht schriftelijke verantwoording (voor studenten)}

Bijlage bij hoofdstuk 7

\section{Portfoliobewijsstuk Communiceren met ouders Competentie samenwerken in en met de omgeving}

Tijdens twee workshops worden communicatieve vaardigheden getraind, besproken en bekeken. Voortgebouwd wordt op kennis en vaardigheden die je hebt opgedaan in 'Communiceren met ouders' in de beroepssituaties 2, 6 en 7. Je werkt hiermee aan de competentie Samenwerken in en met de omgeving. Het doel van de workshops is om je communicatieve vaardigheden te verbeteren, inzicht in (je eigen) communicatiegedrag te vergroten en aan zelfvertrouwen te winnen. Ter voorbereiding op workshop II neem je je voorlopige portfoliobewijsstuk mee. Tijdens de workshop krijg je input voor het afronden van je portfoliobewijsstuk voor de competentie Samenwerken in en met de omgeving.

\section{Voer een gesprek met ouder(s)}

\section{1) Voorbereiding}

Bereid een gesprek met ouders schriftelijk voor. Het kan een 'tienminutengesprek' zijn, maar ook andere formele gesprekken komen in aanmerking. Beschrijf de volgende punten:

- het communicatieve doel;

- de referentiële boodschap;

- opbouw van het gesprek/soort gesprek;

- relevante kenmerken van de gesprekspartner/ouder(s);

- jouw relationele en expressieve boodschap;

- overige informatie die belangrijk is om deze gesprekssituatie te begrijpen, bijv. hoe past dit gesprek in communicatiebeleid van de school, wat ging vooraf aan dit gesprek etc.

- de ruimte waarin het gesprek plaatsvindt, de opstelling van tafel en stoelen;

Beschrijf je eigen aandachtspunt in de gespreksvoering: welk aspect wil jij in 't bijzonder oefenen? Leg uit waarom dit belangrijk voor je is.

Vraag je duo-partner/mentor/andere ervaren leerkracht om het gesprek bij te wonen en jou achteraf schriftelijk feedback te geven op je aandachtspunt in de gespreksvoering.

\section{2) Gespreksvoering en opname ${ }^{14}$}

Voer het gesprek en neem het op. Maak gebruik van digitale video (camera, mobiel, flip). Het is vooral belangrijk dat jij goed in beeld bent, de ouder hoeft niet per se in beeld te zijn. Wel moet je de ouder(s) goed kunnen horen. Zorg voor een goede kwaliteit van beeld en geluid. Neem dus kwesties als licht en tegenlicht in acht.

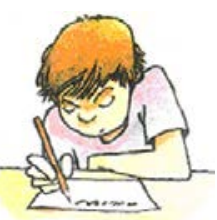
Eventueel kun je alleen een audio-opname maken.

\footnotetext{
${ }^{14}$ Overleg van tevoren met de basisschool over het maken van (video-)opnamen. Vraag ook toestemming aan de betreffende ouders. Het gaat uitsluitend om opnamen voor opleidingsdoeleinden, ze worden niet anderszins gepubliceerd! Dit is belangrijk om te vermelden.
} 


\section{3) Analyse en reflectie}

Maak voor theoretische begrippen gebruik van de website SherpaPro > bibliotheek > zoeken op kennisconcepten > domein Communicatie. Deze site bevat informatie en snelle links naar handige sites, bijvoorbeeld over gesprekstechnieken. Een paar klikken en je bent er!

\section{Analyseer gesprek}

Bekijk je hele video-opname. Selecteer 2 delen van de opname: één stukje waarin je tevreden bent over je eigen communicatieve gedrag, één waarin je niet of minder tevreden bent. Lengte van elk fragment: max. 2 min. Markeer de stukken zodanig in het geheel dat je ze gemakkelijk kunt vinden en laten zien.

Leg met behulp van professionele termen uit wat in beide fragmenten gebeurt.

Beargumenteer wat je goed of minder goed vindt aan je communicatieve gedrag.

Analyseer vervolgens het hele gesprek. Betrek daarbij de volgende onderwerpen.

- Effectiviteit

Was het gesprek geslaagd voor de ouders? Hoe weet je dat?

Was het gesprek geslaagd voor jou? In hoeverre is je communicatieve doel bereikt en hoe weet je dat? Had je ook een beleidsdoel? In hoeverre is je referentiële boodschap overgekomen?

- Verhouding tussen gesprekspartner(s)

Welke indruk heb jij op de ouders gemaakt, ofwel, welke relationele en expressieve boodschap heb je uitgedrukt? Hoe was de relationele en expressieve boodschap van de ouders aan jou? Waaruit maakte je dat op? Hoe reageerde jij daarop?

- Gesprekverloop

Welke gespreksvaardigheden heb je ingezet?

In hoeverre nam jij de leiding in het gesprek? Hoe heb je dat gedaan? Waarom lukte dat wel of niet?

In hoeverre heb je de opbouw van het gesprek in de gaten gehouden en gestuurd?

- Andere relevante zaken

Op welke manier hadden allerlei contextfactoren invloed op het gesprek? Denk daarbij aan de dynamische driehoek, loyaliteit, ouderbetrokkenheid, communicatiebeleid, eerdere gesprekken, jouw positie als Lio ... etc.

\section{Reflecteer}

Ben je tevreden over dit gesprek? Wat levert de feedback van je mentor je op? Wat zou je een volgende keer eventueel anders doen?

Beschrijf in hoofdlijnen, los van dit ene gesprek, over welke aspecten van jouw 'communicatie met ouders' je tevreden bent. Wat zijn jouw sterke punten? Denk daarbij ook aan gesprekken die je eerder hebt gevoerd of geobserveerd.

Waarin wil je je verder bekwamen?

Wat vind jij belangrijk in de communicatie met ouders, als leerkracht en als school?

Neem mee naar tweede workshop:

- gespreksvoorbereiding

- gehele digitale video-opname met gemarkeerde stukjes, op usb

Lever gehele bewijsstuk in het digitaal portret in bij PO-COMMUNICATIE:

- gespreksvoorbereiding

- gehele digitale video-opname met gemarkeerde stukjes

- analyse en reflectie 


\section{Bijlage G \\ Opdracht Samenvatting reflectief gesprek (voor studenten)}

Bijlage bij hoofdstuk 7

\section{Groepsopdracht Mondelinge samenvatting op flip}

Vat jullie gesprek samen in maximaal 5 minuten.

Gebruik, op een passende manier, theoretische begrippen die bij communicatie horen.

Bereid de gezamenlijke samenvatting eerst schriftelijk (in steekwoorden) voor.

Daarna vertelt één van jullie de samenvatting en neemt een ander die samenvatting op met FLIP. Je mag ook iedereen achter elkaar het woord geven voor punt 2, 3 en 4.

Bewaak de tijd!

De samenvatting bevat in ieder geval:

1. Voor- en achternamen én klas aan het begin van de video;

2. Jullie belangrijkste gespreksonderwerpen bij het bespreken van elkaars video;

3. Per persoon het belangrijkste wat je hebt geleerd over communicatie door het uitvoeren van de portfolio-opdracht in je liostage, de zogenaamde leeropbrengst. Als je de portfolio-opdracht nog niet hebt gedaan, zeg dat er dan bij. Vertel dan wat je belangrijkste leeropbrengst is n.a.v. andere ervaringen met ouders in je stage;

4. Per persoon je sterke en zwakke kanten in communicatie met ouders.

Zorg voor een rustige omgeving, zodat het geluid goed verstaanbaar is, het beeld duidelijk én de lichtinval goed (geen tegenlicht bijv.).

Voorbeeld van gespreksonderwerp (ad 2)

‘Wij hebben over drie onderwerpen lang gepraat. Eerst over de context waarin een gesprek met ouders zich afspeelt. Het is heel lastig om er als lio achter te komen wat er allemaal al eerder door de mentor is besproken met de ouders. Je leest wel iets in zo'n dossier, want daar staan alle officiële dingen in. Maar om van tevoren te weten met wat voor ouders je te maken hebt, moet je heel veel aan je mentor vragen. Anders kun je je helemaal niet voorbereiden op de manier waarop je de ouders het beste kunt benaderen, dus eigenlijk kun je dan je relationele en expressieve boodschap niet voorbereiden.

Het tweede onderwerp was ...' etc.

Voorbeeld van leeropbrengst (ad 3)

'Het belangrijkste dat ik heb ontdekt is dat het vooral handig is om me goed voor te bereiden op het communicatieve doel van een gesprek. Eerst dwaalde ik veel meer af en kwam er dan achteraf achter dat ik 't belangrijkste helemaal niet gezegd had. Dan liet ik me leiden door wat de ouders zeiden.' 


\section{Bijlage H \\ Voorbeeld van protocol Samenvatting reflectief gesprek}

Bijlage bij hoofdstuk 7

\section{Protocol Geval 12 (01:18)}

\section{Gespreksonderwerpen}

M) Wij zijn Cynthia en Marjolein uit BB4a. Wij hebben tijdens de mondelinge samenvatting onze eigen ervaringen gedeeld over gesprekken met ouders. Dat waren vooral spontane gesprekken in de klas of op het schoolplein waarbij de ouders naar je toe komen met een vraag of met een opmerking.

\section{Leeropbrengst $\mathbf{M}$}

Wat heb ik geleerd van deze portfolio-opdracht? Belangrijk bij gesprekken met ouders is een goede voorbereiding. Op papier zetten wat je wil bereiken zodat je niet afdwaalt van het gespreksonderwerp. De gespreksvaardigheden moet je natuurlijk goed beheersen. Je moet je bewust worden van je houding en hoe je overkomt op de leerkracht (bedoeld wordt 'ouders'). Hierbij is de dynamische driehoek erg belangrijk. Je moet een goede relatie hebben met zowel het kind als met de ouders en hierbij speelt loyaliteit een grote rol.

\section{Leeropbrengst $\mathrm{C}$}

Wat ik heb geleerd van de portfolio communicatie en dus de lessen die we hebben gehad op de pabo. Je moet echt letten op de opbouw van het gesprek, hoe dat in elkaar zit, hoe je dat moet opbouwen en voorbereiden. We hebben geleerd welke doelen een gesprek kan hebben, dat is uh expressief, relationeel, referentiëel en appellerend. Dat zijn doelen waar een gesprek sowieso aan moet voldoen. En dan hebben we de communicatieve doelen gehad die bij appellerend horen. En we hebben ook heel veel te maken gehad met interculturele gesprekken. Hoe ga je om met gesprekken met mensen uit een andere cultuur? In mijn liostage heb ik ook wel gemerkt dat je veel meer contact hebt met ouders, niet alleen spontaan in de klas of op het schoolplein, maar ook dat je aanwezig bent bij 10-minutengesprekken en oudergesprekken en dat je ook veel meer leert over het kind doordat je contact hebt met ouders.

\section{Sterke en zwakke kanten}

De sterke en zwakke kanten die ik heb nog opgeschreven voor mezelf. Ik heb voor mijn eigen gevoel wel genoeg geduld, ik kan goed luisteren en met gevoelens uiten, daar heb ik ook geen problemen mee. Alleen mijn zwakke punten vind ik doorvragen, - soms vind ik dat moeilijk bij bepaalde onderwerpen - gevoelens beoordelen van andere mensen en initiatief nemen tot oplossingen of adviezen te komen, dat vind ik nog moeilijk. 


\section{CURRI CULUM VITAE}

Christine Kemmeren heeft Algemene Literatuurwetenschap gestudeerd in Nijmegen en London (1993, cum laude) en een postdoctorale opleiding gevolgd waarmee ze een eerstegraads lesbevoegdheid behaalde aan de Universiteit van Utrecht (1997). Zij heeft werkzaamheden verricht in de journalistiek en het intercultureel onderwijs waar ze lesgaf aan niet-Nederlandstalige vrouwen. Sinds 1997 is zij werkzaam als docent Nederlands \& taaldidactiek, lerarenopleider en onderzoeker in de lerarenopleiding voor basisonderwijs.

Binnen haar werk combineert Christine haar talige achtergrond en haar interesse in onderwijsvernieuwing in uiteenlopende taken zoals studentbegeleiding, professionaliseringstrajecten en onderzoeks- en ontwikkelprojecten. Zij draagt literatuur en kunst in de lerarenopleiding een warm hart toe en is mede-auteur van een boek voor studenten over leesbevordering. Haar expertise ligt met name op het terrein van onderwijsvernieuwing en curriculumontwikkeling. Een constante in haar werk is de combinatie van onderwijspraktijk en onderzoek.

$\mathrm{Zij}$ is sinds 2004 verbonden aan het lectoraat Rich Media \& Teacher Learning. Een project binnen dit lectoraat heeft geleid tot een promotieonderzoek naar de relatie tussen conceptuele kennis en professioneel handelen van aankomende leraren. Dit promotieonderzoek is uitgevoerd aan de Universiteit Twente.

Christine is momenteel werkzaam als hoofddocent en onderzoeker bij de lerarenopleiding van Saxion, Academie Pedagogiek en Onderwijskunde. Zij is tevens verbonden aan de masteropleiding Leren \& Innoveren. Christine is, in het verlengde van haar promotieonderzoek, betrokken bij onderzoeksprojecten op het gebied van curriculumontwikkeling. 
